MARIA AUGUSTA FERREIRA DA SILVA CASTANHO

\title{
O PROCESSO ELEITORAL NA ERA DA INTERNET: AS NOVAS TECNOLOGIAS E O EXERCÍCIO DA CIDADANIA
}

Tese de Doutorado

Orientadora: Professora Doutora Monica Herman Salem Caggiano

Faculdade de Direito da Universidade de São Paulo

São Paulo

2014 


\title{
O PROCESSO ELEITORAL NA ERA DA INTERNET: AS NOVAS TECNOLOGIAS E O EXERCÍCIO DA CIDADANIA
}

\author{
Tese de Doutorado apresentada à \\ Comissão de Pós-Graduação Stricto \\ Sensu da Faculdade de Direito da \\ Universidade de São Paulo como \\ requisito parcial para a obtenção do \\ título de Doutora em Direito. \\ Área de Concentração: Direito do Estado
}

Orientadora: Professora Doutora Monica Herman Salem Caggiano

Faculdade de Direito da Universidade de São Paulo São Paulo

2014 


\section{O PROCESSO ELEITORAL NA ERA DA INTERNET: AS NOVAS TECNOLOGIAS E O EXERCÍCIO DA CIDADANIA}

Tese de Doutorado apresentada ao Programa de Pós-Graduação Stricto Sensu da Faculdade de Direito da Universidade de São Paulo na área de concentração Direito do Estado como requisito parcial para a obtenção do grau de Doutor em Direito.

Aprovada em:

Banca examinadora:

Professora Doutora Monica Herman Salem Caggiano - Orientadora

Titulação, nome e instituição à qual está vinculado

Titulação, nome e instituição à qual está vinculado

Titulação, nome e instituição à qual está vinculado

Titulação, nome e instituição à qual está vinculado 
Para Bebiana. 


\section{AGRADECIMENTOS}

Agradeço a Deus, por ser a força que me impulsionou em tantos momentos áridos e inseguros, me ajudando a seguir em frente, mantendo a mente firme e positiva, na busca dessa grande realização.

À mão segura da orientação dada pela Professora Doutora Monica Hermann Salem Caggiano, que me inspirou (e posso dizer, com certeza, não só a mim, mas a todos que são brindados com a possibilidade desse convívio) com seus ensinamentos generosos e sua erudição acadêmica, por meio dos quais nos faz refletir, a cada momento, o quão importante é a valorização da liberdade e da democracia, e me ofertou a oportunidade de concluir esta tese, apesar de minhas limitações.

Minhas dúvidas e angústias não teriam sido superadas sem os imprescindíveis comentários e sugestões levantados pelos Professores Cláudio Lembo e Rubens Beçak, que me apontaram novos rumos para este trabalho, não só no Exame de Qualificação, mas ao longo de todos os anos em que dividiram seus vastos ensinamentos sobre história, direito e política, nas aulas ministradas nesta instituição.

Agradeço também a todos os mestres ilustres desta casa, que desde a graduação me inspiram e franqueiam preciosos comentários.

Aos funcionários da Faculdade de Direito da Universidade de São Paulo, sempre a nos ajudar e ouvir, e que nos acolhem com gentileza e paciência.

Durante minhas marchas e contramarchas, fui recebida com muito amor e sorrisos, e de braços sempre abertos, pela minha mãe querida, Bebiana Castanho, pelo meu grande e afetuoso companheiro, Guga Santos, com seus “carinhos sem ter fim”, e pelos meus sinceros amigos, em especial, por Lara Côrtes, e sua paciência para as intermináveis análises, essenciais para a conclusão desta tese. Todos vocês são exemplo de lealdade e motivação nessa jornada. E, ainda, Rony Farto Pereira, que surgiu, de repente, contribuindo para que a leitura desse trabalho fosse muito mais agradável. Com eles, tenho uma dívida eterna de gratidão, e espero poder retribuir à altura. 
de cima do palanque

de cima da alta poltrona estofada

de cima da rampa

olhar de cima

LÍDERES, o povo

Não é paisagem

Nem mansa geografia

Para a voragem

Do vosso olho.

POVO, POLVO

UM DIA.

O povo não é o rio

De mínimas águas

Sempre iguais.

Mais fundo, mais além

E por onde navegais

Uma nova canção

De um novo mundo.

E sem sorrir

Vos digo:

O povo não é

Esse pretenso ovo

Que fingis alisar,

Essa superfície

Que jamais castiga

Vossos dedos furtivos.

POVO. POLVO.

LÚCIDA VIGÍLIA.

UM DIA.

Hilda Hilst. Júbilo, Memória, Noviciado da paixão. 
CASTANHO, Maria Augusta Ferreira da Silva. O Processo Eleitoral na era da internet: as novas tecnologias e o exercício da cidadania. Tese (Doutorado) Faculdade de Direito, Universidade de São Paulo, São Paulo, 2014.

\section{RESUMO}

O desenvolvimento das tecnologias de informação e comunicação (TIC) alterou profundamente o modo de governança e as formas de convívio social, produzindo efeitos sobre a participação política. A presente tese aborda o elo entre o processo eleitoral e a Internet e analisa os determinantes da participação eleitoral no Brasil. O estudo desenvolvido tem início com o estado da arte do Direito Eleitoral, abordando o papel de seus atores políticos e os procedimentos que envolvem a operação eleitoral, buscando compreender as contribuições trazidas pela Internet para essa dinâmica. Em seguida, analisamos a forma como a Internet vem sendo utilizada nos processos eleitorais pelos agentes políticos, seus limites e possibilidades, com o objetivo de verificar qual o potencial da Internet para revigorar a democracia e aprimorar o exercício da cidadania. Apresentamos, ainda, propostas de regulação para aperfeiçoar o aproveitamento das ferramentas e potencialidades da Internet, durante o processo eleitoral, indicando, por fim, algumas práticas dessa utilização em outros países. O quadro analítico proposto revela que a expansão da Internet e suas mídias sociais e a liberdade encontrada em seu espaço virtual possuem um efeito positivo sobre a participação eleitoral.

Palavras-chave: Direito Eleitoral. Internet. Comunicação Eleitoral. Campanhas Políticas. 


\begin{abstract}
The development of digital information and communications technologies (ICT) profoundly changed governance and social interaction, producing effects on the political participation. This thesis approaches the relation between the electoral process and Internet, and observes the determinants of electoral participation. The study begins with the estate of art of Electoral Law, analysing the role of the political actors and the operating electoral procedures, seeking an understanding of the Internet contributions for this dynamics. Subsequently, we oulined the way Internet has been used by the political agentes in the electoral process, its limitations and possibilities, examining the Internet potential to revitalize democracy and improve the exercise of the citizenship. We will present, moreover, regulation proposals to improve the usage of Internet tools and potetialities during the electoral process, showing a few examples that take place in the international scenario. The analytical framework reveals that the spread of the Internet and its social media, and the freedom found in its virtual space produce a positive effect on the electoral participation.
\end{abstract}

Keywords: Electoral Law. Internet. Electoral Communication. Brazilian Political Campaigns. 


\section{RÉSUMÉ}

Le développement des technologies de l'information et de la communication (TIC) a profondément bouleversé les modes de governance et les schémas de relation entre les hommes, avec des effets à la participation politique. Cette thèse aborde le lien entre le processus électoral et l'Internet et s'intéresse aux déterminants de la participation électorale au Brésil. Notre travail débute par un état de l'art du Droit Électoral qui porte une attention particulière au rôle des acteurs politiques et aux procédures électorales, et nous avons analysé les contributions amenées par l’Internet à cette dynamique. Ensuite, nous nous sommes intéressés à la manière dont les agents politiques utilisent l'Internet pour les élections, ainsi qu'aux limites et possibilités de cet outil dans le but de vérifier le potential de l'Internet pour revigorer la démocratie et améliorer l'exercise de la citoyenneté. Nous présentons des propositions pour régler l'utilisation des outils et potentialités dans les procédures électorales. Finalement, nous indiquons quelques modèles internationaux qui ont adapté l'Internet aux élections. Le cadre analytique proposé suggère que l'expansion de l'Internet et des médias sociaux, et la liberté de cet espace virtual ont un effet positif sur la participation électorale.

Mots-clés: Droit Électoral. Internet. Comunication Électorale. Campagnes Politiques. 


\section{LISTA DE ACRÔNIMOS E SIGLAS}

\begin{tabular}{|c|c|}
\hline $\mathrm{CE}$ & Código Eleitoral \\
\hline $\mathrm{CF}$ & Constituição Federal \\
\hline DEM & Democratas \\
\hline IBGE & Instituto Brasileiro de Geografia e Estatística \\
\hline IBOPE & Instituto Brasileiro de Opinião Pública e Estatística \\
\hline LAI & Lei de Acesso à Informação \\
\hline LE & Lei Eleitoral \\
\hline ME5 & Movimento 5 Estrelas \\
\hline PCdoB & Partido Comunista do Brasil \\
\hline PCB & Partido Comunista Brasileiro \\
\hline PCdoB & Partido Comunista do Brasil \\
\hline PFL & Partido da Frente Liberal \\
\hline PL & Partido Liberal \\
\hline PLP & Projeto de Iniciativa Popular \\
\hline PMDB & Partido do Movimento Democrático Brasileiro \\
\hline PNAD & Pesquisa Nacional por Amostra Domiciliar \\
\hline $\mathrm{PP}$ & Partido Progressista \\
\hline PPB & Partido Progressista Brasileiro \\
\hline PR & Partido da República \\
\hline PRONA & Partido da Reedificação da Ordem Nacional \\
\hline PROS & Partido Republicano da Ordem Social \\
\hline PSDB & Partido da Social Democracia Brasileira \\
\hline PSOL & Partido Socialismo e Liberdade \\
\hline PSTU & Partido Socialista dos Trabalhadores Unificado \\
\hline PT & Partido dos Trabalhadores \\
\hline PTB & Partido Trabalhista Brasileiro \\
\hline TICs & Novas Tecnologias de Informação e Comunicação \\
\hline TSE & Tribunal Superior Eleitoral \\
\hline TRE & Tribunal Regional Eleitoral \\
\hline
\end{tabular}


INTRODUÇÃO

\section{CAPÍTULO I - O PAPEL DO DIREITO ELEITORAL NA CONSOLIDAÇÃO}

DA DEMOCRACIA E NO EXERCÍCIO DA CIDADANIA ........................................ 21

1.1 Direito Eleitoral: sufrágio, eleitores, candidatos .................................................. 23

1.2 Tratamento legal brasileiro …………………………...................................... 40

1.2.1 Constituição Federal de 1988 ……………………………………………..... 41

1.2.2 Lei 4.737/65 - Código Eleitoral................................................................. 45

1.2.3 Lei Complementar no 64/90 - Lei das inelegibilidades .................................... 48

1.2.4 Lei 9.096/95 - Lei dos partidos políticos ....................................................... 49

1.2.5 Lei 9.504/ 97- Lei das Eleições..................................................................... 52

1.2.6 Lei 12.034/09 - Minirreforma política e eleitoral............................................. 56

1.2.7 LC 135/10 - Lei da Ficha Limpa ................................................................ 60

1.3 Histórico e relevância da Justiça Eleitoral no Brasil ................................................ 64

CAPÍTULO II - ELEIÇÕES E PARTICIPAÇÃO POPULAR .................................. 75

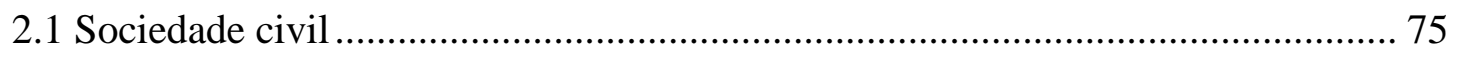

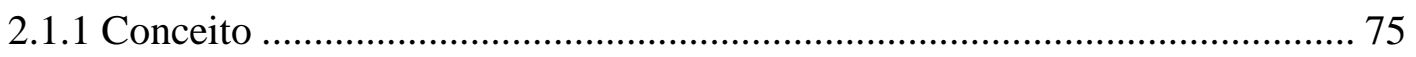

2.1.2 Relação entre sociedade civil e Estado ........................................................ 87

2.1.3 Liberdade de expressão e manifestação ......................................................... 101

2.2 Representação política e sistemas eleitorais ...................................................... 110

2.3 O papel dos partidos políticos no processo eleitoral........................................... 131

2.3.1. Origem e evolução dos partidos políticos .................................................... 131

2.3.2 A natureza jurídica dos partidos políticos .................................................... 145

2.3.3 Criação, registro, estrutura e extinção dos partidos políticos........................ 148

2.3.4 O princípio do pluralismo e a atuação dos partidos políticos ........................ 154

\section{CAPÍTULO III - PROPAGANDA ELEITORAL COMO INSTRUMENTO DE} COMUNICAÇÃO POLÍTICA............................................................................ 164

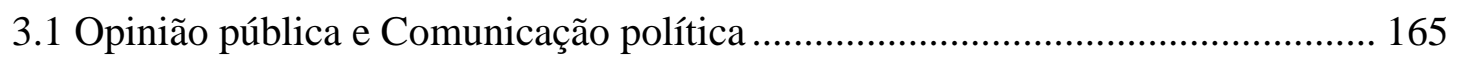

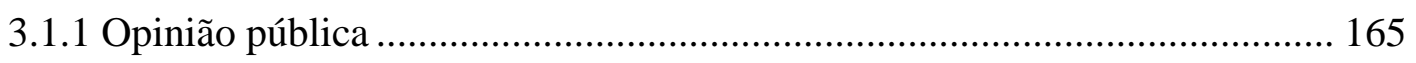

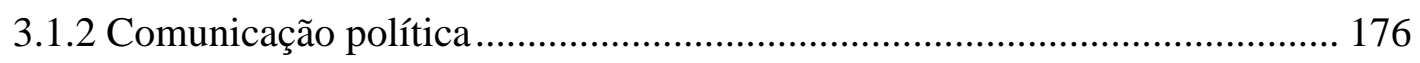

3.2 Disputa eleitoral: igualdade, liberdade e regulamentação .................................. 187 
3.3 Propaganda política: análise da legislação eleitoral aplicável ........................... 197

3.4 Limites jurídicos ao uso da Internet nas campanhas eleitorais: propostas........... 209

CAPÍTULO IV - ELEIÇÕES, INTERNET E PARTICIPAÇÃO CIDADÃ ....... 219

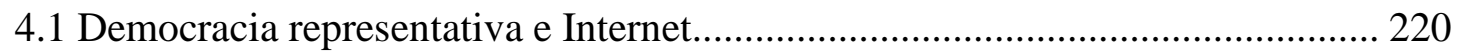

4.2 Facebook, Twitter, YouTube, Blogs: conceito, arquitetura e importância........... 239

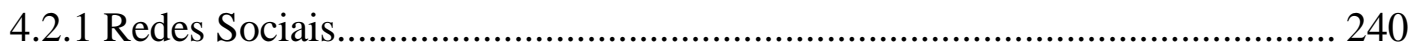

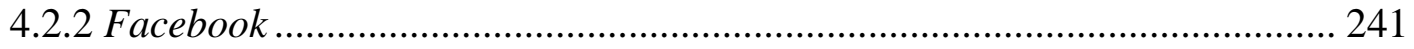

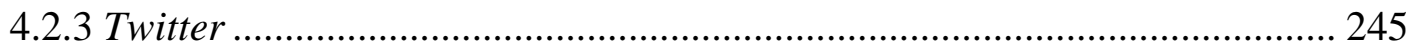

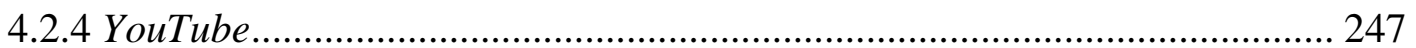

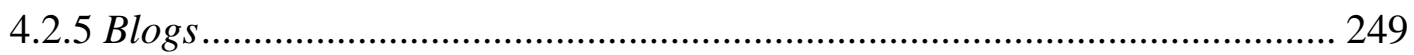

4.3 Uma perspectiva do uso Internet nos recentes quadros eleitorais brasileiros ..... 254

4.4 Legislação específica e o Twitter na visão do TSE: novos debates e

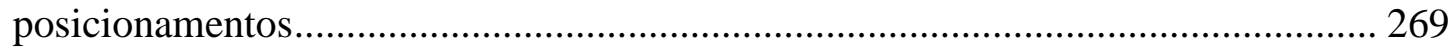

4.4.1 Lei de acesso à informação (LAI) ............................................................ 270

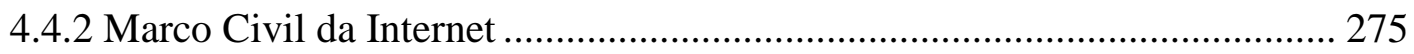

4.4.3 Posicionamento do TSE sobre o Twitter .................................................. 279

CAPÍTULO V - INTERNET E ELEIÇÕES: UM NOVO AMÁLGAMA NA

DEMOCRACIA. MODELOS ESTRANGEIROS ................................................ 287

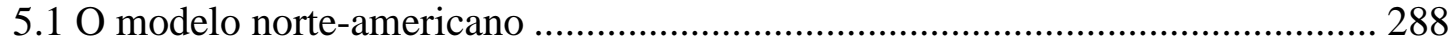

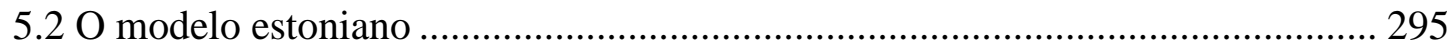

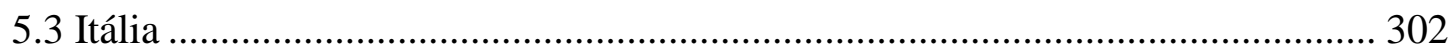

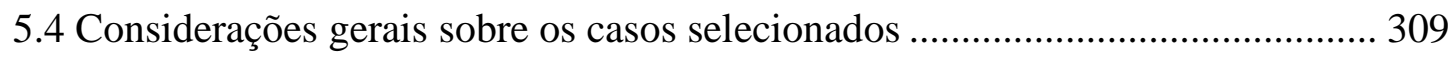

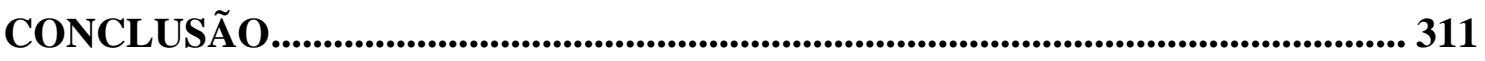

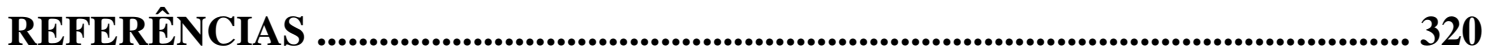




\section{INTRODUÇÃO}

O contexto de análise da presente tese se insere no momento eleitoral, uma das dimensões a constituir o modelo democrático representativo, por meio do qual o povo define quem serão seus representantes, aqueles a lhes dar proteção, defendendo seus direitos, implementando o fortalecimento das instituições e assegurando a liberdade e igualdade que devem ser partilhadas por todos. ${ }^{1}$

A representação é um processo político de conotação única, posto que baseado em uma estrutura de circularidade entre as instituições e a sociedade, isto é, ela não se reduz à deliberação e decisão na assembleia, devendo ser vista de uma forma dinâmica, que impõe o constante aprimoramento e a observância das ideias e opiniões dos cidadãos sobre a relação sociedade e Estado. ${ }^{2}$ A representação exige a permanente vinculação da sociedade, que não delega seu poder, mas participa do processo de tomada de decisão, influenciando a direção política do país. Explica Urbinati que

[...] a representação não pode ser reduzida nem a um contrato (de delegação) firmado através das eleições nem à nomeação dos legisladores como substitutos do soberano ausente, porque sua natureza consiste em ser constantemente recriada e dinamicamente ligada à sociedade. Em suma, a história moderna sugere que a genealogia da democratização começou com o processo representativo. A democratização do poder estatal e o poder unificador das ideias e movimentos políticos levados a cabo pela representação foram interconectados e mutuamente reforçadores. ${ }^{3}$

É necessário pontuar que a representação não se reduz ao momento eleitoral. Apesar de as eleições simbolizarem um dos eixos da democracia representativa, esse modelo também exige liberdade de expressão, associação e informação, inclusão política e social e uma cultura ética de cidadania.

1 É no momento em que a democracia assume os moldes dados pela representação que ela se torna compatível com a República, ao promover a inclusão social e a participação de todos. Hodiernamente, intitular-se uma república democrática passou a ser o ideal de quase todos os países, cada um com sua fórmula.

2 URBINATI, Nadia. Representative democracy: principles and genealogy. Chicago: The University of Chicago, 2006.

3 URBINATI, Nadia. O que torna a representação democrática? Lua Nova, São Paulo n. 67, p. 192193, 2006, p. 195. 
A cidadania, da forma concebida hoje, está associada ao processo de construção da modernidade, que resultou na Declaração dos Direitos do Homem e do Cidadão, derivada da Revolução Francesa de 1789.

Depois disso, a própria sociedade passa a se inventar e a se autoproduzir no contexto histórico capitalista, como expressão do homem livre e competitivo. O homem substitui a perspectiva da predestinação presente na Idade Média e passa a ser o centro do universo, formulando um pacto civilizatório livremente construído, pelo qual deve haver respeito às normas estabelecidas, com a incorporação de valores que permitem o convívio social e a resolução de conflitos. A construção da cidadania ocorre dentro desse processo histórico, com a formulação de um direito que propõe leis de caráter genérico e abstrato, exaltando a liberdade e a igualdade.

Esse direito, entretanto, não assegura a cidadania de todos, pois essa dinâmica pode gerar a manutenção do poder por uma classe dirigente, em detrimento de outros grupos sociais, o que fragmenta a sociedade. Com isso, surge a necessidade constante de se dar unidade e consistência ao conceito de cidadania, não só como o direito de convivência, mas como uma forma de articulação entre os grupos, para que eles renovem o contrato entre as diferentes camadas sociais, estabelecendo a governabilidade de forma legítima. A elaboração conceitual do termo cidadania e a criação de novos modelos democráticos buscam esse intento, sugerindo formas de combinação e aceitação entre o instituído pela lei e os questionamentos populares, entre as propostas advindas da pressão popular e as próprias mudanças históricas que ocorrem mundialmente.

Em dissertação desenvolvida no Mestrado, ${ }^{4}$ o modelo proposto foi ainda o da tão combalida e criticada democracia representativa, desta vez aprimorada com o uso dos mecanismos trazidos pelas tecnologias de comunicação, principalmente pela

4 Dissertação de Mestrado defendida na Universidade Presbiteriana Mackenzie, em 2009, sob a orientação da Professora Doutora Monica Hermann Salem Caggiano, intitulada E-democracia: a democracia do futuro?, que apresenta o modelo da democracia eletrônica como aquele apto a revigorar a democracia representativa. Desde a década de 1990, a inserção de novos meios de comunicação virtuais multiplicou o número de estudos dedicados à participação política online. Destacamos a obra de Manuel Castells, a qual sustenta que as novas tecnologias de comunicação e informação vão afetar profundamente a sociedade e suas práticas, dentre elas, a prática política. Além desses, ler também Pippa Norris e sua obra $A$ virtuous circle: political communications in postindustrial societies; Richard Gunther and Anthony Mughan, com Democracy and the media: a comparative perspective; e David Swanson e Paolo Mancini: Politics, media and modern democracy. 
Internet, uma ferramenta que apresenta problemas e falhas, mas cujas potencialidades permitem estabelecer interações mais fortes entre membros da esfera pública e da esfera civil. A questão não é mais saber se a Internet vai alterar a maneira de viver em sociedade; a questão é como e com que intensidade isso acontecerá, pois essa situação já é um fato. ${ }^{5}$ A defesa da dissertação se deu no sentido de mostrar que a Internet é capaz de fortalecer as instituições representativas, além de tornar mais densos os canais de representação e promover mecanismos de participação mais ágeis e amplos. A participação popular, mediada pelas tecnologias digitais, serviria como mais uma alternativa para a superação dos problemas existentes no modelo representativo, que deve ser revigorado, e não substituído. ${ }^{6}$ A Internet seria capaz de reformular a cidadania, ao estimular, entre outras coisas, a cultura da tolerância, do pluralismo, da participação, com reconhecimento e efetividade dos direitos de todos.

A presente tese, por sua vez, aborda a relação entre a Internet e o processo eleitoral brasileiro, avaliando os impactos dessa nova forma de comunicação sobre o Direito Eleitoral e participação do cidadão, sobre os resultados eleitorais, e apresenta, outrossim, algumas propostas para sua utilização nas eleições vindouras. Ademais, apresenta uma perspectiva comparada para o tema, discutindo os casos dos Estados Unidos, Estônia e Itália.

As questões que envolvem a tomada da decisão política pelo voto popular são precedidas por um processo de debate público acerca dos assuntos que interessam a todos. Esse processo se constitui em diferentes esferas da sociedade - que é fluida e

5 “A maioria das pessoas que acessam as notícias através da mídia convencional desconhece a impressionante variedade de novas culturas que tem evoluído no mundo das redes de computador nos últimos dez anos. A maioria das pessoas que ainda não usaram tais novas mídias permanecem inconscientes de quão profundamente os experimentos sociais, políticos e científicos desenvolvidos atualmente via redes de computadores podem mudar nossas vidas em um futuro próximo.” RHEINGOLD, Howard. A comunidade virtual. Lisboa: Gradiva, 1996, p. 23. Afirmação feita há mais de 15 anos e que se tem mostrado cada vez mais acertada. Nos Estados Unidos, já há iniciativas - code.org, por exemplo - que sustentam a necessidade de aprender programação na escola. Para Lemos, “[...] o que está em jogo aqui é o futuro da organização social. A tecnologia abre possibilidades extraordinárias de participação na vida pública. Só que saber um mínimo de programação é o requisito para que a ideia de democracia se perpetue.” LEMOS, Ronaldo. Não saber programar é o analfabetismo do futuro. Disponível em: <http://www1.folha.uol.com.br/colunas/ronaldolemos/2013/11/1365651-nao-saber-programar-e-oanalfabetismo-do-futuro.shtml>. Acesso em: 04 nov. 2013.

6 Embora o século XX tenha presenciado a inclusão de mecanismos de democracia direta, a democracia só tem sido viável com base na representação política, um instituto essencial que cria formas de mediação específica entre Estado e sociedade, organizando e traduzindo os interesses dos cidadãos. 
complexa - e a partir de diversas etapas, como a propagação de informações, a explanação de argumentos e o desenvolvimento de alternativas. Ao longo dessas etapas, nos períodos anteriores às eleições, ocorrem processos simultâneos e relacionados, como a formação da agenda dos candidatos e partidos interessados na vitória, e a formação da agenda da mídia com a cobertura dessa disputa.

O Direito Eleitoral aborda todos essas fases, delimitando regras para o seu bom funcionamento. Com isso, o processo eleitoral se torna um momento privilegiado do exercício da cidadania, pois a discussão sobre as plataformas abre o precedente para a discussão sobre as questões pertinentes à comunidade, ampliando a análise para as questões do país. A Internet oferece possibilidades de comunicação de mão dupla, por meio de seus debates multidirecionais e transparentes, que possibilitam novas formas de diálogo político e de fortalecimento da accountability ${ }^{7}$ governamental.

Além disso, a Internet fortalece o capital social. Putnam ${ }^{8}$ observa que o espaço on line reconcilia as demandas por maiores vínculos sociais. Baseadas em interesses afins, as pessoas se integram, por intermédio de newsgroups, emails e websites, podendo se engajar em uma deliberação significativa, interrompendo a espiral que retrata o declínio da participação popular na via política. Assim, o locus da representação continua sendo, fundamentalmente, o Parlamento, mas ele se vê alargado por outros sistemas de mediação social. ${ }^{9}$

Nas comunidades tradicionais, as pessoas interagem umas com as outras de forma presencial, respeitando os limites de tempo e espaço. A comunicação digital derruba essas barreiras, mas sem alterar os princípios fundamentais da constituição de

7 A ideia de accountability refere-se ao controle e à fiscalização dos agentes públicos e acarreta a responsabilização política de governantes e burocratas por seus atos e omissões. Indicamos, para aprofundamento do tema, a obra de Guillermo O’Donnell, que será recobrada adiante, bem como o estudo de Scott Mainwaring e Christopher Welma apresentada no livro de 2003 Democratic accountability in Latin America, além da sempre relevante análise de Bernard Manin, Adam Przeworski e Susan Stokes intitulada Democracy, accountability and representation contida na obra organizada pelos mesmos autores Elections and representation, de 1999.

8 PUTNAM, Robert. Bowling alone. New York: Simon and Schuster, 2000, p. 17.

9 Os atores da política - como partidos, sindicatos, associações - se esforçam para contribuir para decisões dos poderes públicos, mas eles têm avaliado muito mal as transformações responsáveis pelo surgimento dessa "sociedade em rede", apegando-se a projetos políticos ultrapassados. A baixa participação nas eleições é uma constatação global dos países de democracia ocidental, evidenciando um desgaste da sociedade civil em relação à vida política. Por isso, as constantes propostas de revigoramento do processo eleitoral. 
uma comunidade, como interação entre os participantes, interesse comum, confiança mútua, escolha de liderança e estímulo para a participação, o que, em último caso, é o que justifica a continuidade da comunidade.

Essas comunidades virtuais evoluíram, ${ }^{10}$ apresentando-se atualmente sob a roupagem de redes sociais, nas quais as pessoas colocam fotos e vídeos, registram seus dados pessoais, participam de jogos, assumem novos papéis. Por enquanto, seu uso ainda é instrumental, relacionado à família, trabalho e tarefas diárias. Um dos sites mais acessados no mundo e também no Brasil, o Facebook, acompanha esse perfil de utilização. A questão é perceber em que sentido essas redes sociais e outras comunidades afins passarão a exercer uma atuação política, articulando sua dinâmica para o aprimoramento da cidadania.

Afinal, há pouca divergência quanto ao fato de que os meios de comunicação de massa exercem um papel crucial na seleção de um candidato. As novas mídias virtuais se alinham no mesmo sentido, fornecendo perspectivas, modelando a aparência dos candidatos e veiculando imagens que influenciam a opinião pública, durante as campanhas. Vários estudos já foram expostos sobre a relação entre as mídias tradicionais - jornais, rádio e televisão - e o momento eleitoral ${ }^{11}$. A relevância da presente tese é exatamente a de fazer uma abordagem aprofundada sobre a atuação das ferramentas disponibilizadas pela Internet e o ambiente eleitoral democrático, na tentativa de explorar suas possibilidades, apontar seus defeitos, exaltar seus feitos e concluir se ela é capaz de fortalecer a cidadania.

Democracia pressupõe uma constante dialética do debate, pressupõe o convívio suportável do consenso com o dissenso. Para que um Estado se afirme Democrático de Direito, o consentimento deve ser fruto do processo dialético de discussão com a

10 A ideia das primeiras comunidades virtuais é sugerida por Rheingold, em obra acima mencionada. Define o autor que elas são agregações sociais que surgem da rede de computadores e representam um alargamento da sociedade, um novo espaço de interação virtual entre as pessoas, que se aproximariam por possuírem interesses comuns.

11 Em cenário pátrio, sugerimos a leitura da abordagem feita por Luis Felipe Miguel, Alessandra Aldé, Marcelo Coutinho, Vladimir Safatle e Antonio Albino Canelas Rubim, autores que há anos se dedicam ao estudo da influência dos meios de comunicação sobre a participação popular, e cujas obras foram utilizadas para o desenvolvimento desta tese, constando das referências. 
sociedade, e não imposto de cima para baixo, arbitrariamente. É valioso trazer o ensinamento de Bobbio:

Quero dizer que, num regime que se apóia no consenso não imposto a partir do alto, alguma forma de dissenso é inevitável e que apenas onde o dissenso é livre para se manifestar o consenso é real, e que apenas onde o consenso é real o sistema pode proclamar-se com justeza democrática. Por isto afirmo existir uma relação necessária entre democracia e dissenso, pois, repito, uma vez admitido que a democracia significa consenso real e não fictício, a única possibilidade que temos de verificar se o consenso é real é verificando o seu contrário. Mas como poderemos verificá-lo se o impedirmos? ${ }^{12}$

Esses consensos e dissensos possuem um novo espaço de funcionamento, um espaço simbólico em permanente mutação, com regras criadas pelos instrumentos de regulação do Estado, por um lado, e pela convivência de diversos interesses, com fins lucrativos ou não, de outro.

Essas mutações são visíveis nas variadas plataformas e aplicativos criados para uso na Internet, que deram lugar a novas formas de fruição de informação e entretenimento, e permitiram também o surgimento de novas formas de manifestação da opinião, de protesto e organização política. Sua influência afeta todas as instituições sociais.

A cobertura da mídia tradicional sofreu forte impacto com o avanço tecnológico do século XX, no setor das comunicações, e o aprimoramento acelerado de diversas técnicas de comunicação. As redes sociais ampliam as possibilidades de participação e influenciam a constituição da esfera pública, ${ }^{13}$ promovendo o debate e deixando as fronteiras entre Estado e sociedade cada vez mais permeáveis e transparentes. $^{14}$

12 BOBBIO, Norberto. O futuro da democracia. Trad. de Marco Aurélio Nogueira. 8. ed. São Paulo: Paz e Terra, 2002, p. 75.

13 BURKE, Peter; BRIGGS, Asa. Uma história social da mídia: de Gutenberg à Internet. Tradução Maria Carmelita Pádua Dias. 2. ed. ver. e ampl. Rio de Janeiro: Jorge Zahar, 2006, p. 110-113.

14 Os conceitos de transparência e governo aberto não são novos, remontam a pensadores como Madison (1751-1836) e Kant (1724-1804), que os tratava como “razões de Estado", acentuando a necessidade de tornar públicas as ações de poder. Para Kant, essa não era apenas uma exigência política, mas também moral. 
A atuação dos partidos políticos, indispensáveis para a concretização da operação eleitoral, merece atenção. Diante das mudanças trazidas pelo Poder Judiciário, que determinou que o voto é do partido, ${ }^{15}$ não se pode deixar de reconhecer que essa instituição se fortaleceu e, por isso, seu funcionamento, organização, base de financiamento e profissionalismo exigem um olhar atento quando da análise políticoeleitoral. Apesar do descontentamento quanto aos partidos políticos ${ }^{16}$ e aos políticos, em geral, Sartori ${ }^{17}$ nos lembra que “ [...] é a competição entre partidos com recursos equilibrados (políticos, humanos, econômicos) que gera democracia” e, por isso, é fundamental verificar o uso que eles fazem das mídias eletrônicas.

Essa tecnologia, cuja essência se resume à criação, processamento, armazenamento e transmissão de sinais digitalizados, se infiltra em serviços, pessoas e processos, gerando novos bens e atividades, provocando mudanças fundamentais na comunicação, nos métodos de gestão, nas organizações administrativas, além de promover impacto sobre as eleições.

A relação entre Internet e eleições encontra-se em um processo de transformação em curso. Ainda se percebe um grau elevado de indefinição entre essa interação e na sua abordagem pelo sistema político, devido à variedade de estratégias dos atores políticos e das interações entre os campos sociais, culturais e políticos. As diversas telas conectadas em rede, portanto, mantêm-se como um espaço ainda a ser ocupado em sua plenitude pela política. Esta, por sua vez, se vê desafiada a operar atendendo às demandas eletrônicas. Surge a necessidade de novas configurações, que interajam com modelos convencionais de eleições e com as novas formas interativas, operadas de maneira plural e com várias especificidades.

15 A questão de a quem pertence o mandato eletivo foi sedimentada pelo Supremo Tribunal Federal (STF) ao definir que os mandatos pertencem aos partidos, e não aos políticos eleitos. O Plenário do STF declarou improcedentes as Ações Diretas de Inconstitucionalidade n 3999 e 4086 ajuizadas pelo Partido Social Cristão e pela Procuradoria-Geral da República contra a Resolução no 22.610/07 do TSE, assunto que será melhor desenvolvido à frente, neste capítulo. Em 2011, aliás, o STF entendeu que o cargo pertence à coligação e não ao partido, ao analisar dois mandados de segurança, um proposto por Humberto Guimarães Souto (PPS-MG) e outro por Carlos Vitor da Rocha Mendes (PSB-RJ). Usamos no texto a palavra "partido" entendendo que a coligação formaria, a partir dessa decisão, um superpartido.

16 De acordo com o Latinobarómetro, organização que estuda a opinião pública em 17 países latinoamericanos, os partidos políticos são as instituições com os níveis mais baixos de credibilidade cidadã. Disponível em: <http://www.latinobarometro.org>. Acesso em: 14 out. 2012.

17 SARTORI, Giovanni. Homo videns, p. 19. 
A política precisa compreendê-las para poder se locomover nesse espaço com habilidade, sem deixar de lado sua lógica imanente. As campanhas eleitorais têm-se adaptado a essa nova circunstância. Mesmo que de forma embrionária, elas investigam como a política é praticada nas novas mídias e têm elaborado, nas eleições ocorridas no Brasil, formas de convergência entre política e Internet. Surgem os sites partidários, discutem-se temas relevantes ao país nas mídias sociais e candidatos apresentam seus feitos e propostas nos blogs. Além disso, essas plataformas são utilizadas para sondagens de opinião e pesquisas, no processo eleitoral por todos nele envolvidos.

Essa combinação de fatores deve ser cada vez mais democratizada. Os cenários simbólicos da política nunca são neutros, mas organizam vários tipos de ações possíveis para os cidadãos. É fundamental que essas tecnologias estejam a serviço do cidadão e ele saiba aproveitá-las para aprimorar sua participação no debate político, vez que essa ágora virtual é um lugar de conflitos e divergências, mas também de agregação e coesão, possuindo uma dinâmica que atende às constantes mutações sociais, sendo capazes de atribuir um novo sentido à democracia.

Os objetivos da presente tese são apresentar o uso da Internet nas eleições e discutir seus desdobramentos para a democracia e o fortalecimento da cidadania. Mais concretamente, buscamos oferecer uma resposta para a seguinte questão: a Internet muda as regras do jogo eleitoral e colabora para o fortalecimento da cidadania? 


\section{CAPÍTULO I - O PAPEL DO DIREITO ELEITORAL NA CONSOLIDAÇÃO DA DEMOCRACIA E NO EXERCÍCIO DA CIDADANIA}

Posso, sem armas, revoltar-me?

Carlos Drummond de Andrade ${ }^{18}$

O tema cidadania está relacionado ao aperfeiçoamento dos direitos políticos do cidadão, bem como à discussão sobre a necessidade de se incentivar a educação política do povo.

Em obra clássica, Marshall ${ }^{19}$ explicita o conceito moderno de cidadania, considerada um status concedido aos membros de uma comunidade, todos iguais em direitos e obrigações.

Marshall estipulou a tipologia dos direitos de cidadania, falando em direitos civis, que foram alcançados no século XVIII; em direito políticos, conquistados no século XIX; e em direitos sociais, obtidos no século XX.

Esse conceito tem suas raízes na Revolução Francesa. A Declaração dos Direitos do Homem e do Cidadão que, em seu art. 1, afirmou que “[...] os homens nascem e são livres e iguais em direito”, ${ }^{20}$ também tratou de diferenciar os termos "homem” e "cidadão, como afirma Clève: ${ }^{21}$ “[...] a titularidade de todos os direitos foi atribuída ao homem (art. $1^{\circ}$ ), enquanto que ao cidadão foram conferidos apenas os direitos e deveres (os únicos) políticos.”

18 ANDRADE, Carlos Drummond de. A rosa do povo. São Paulo: Companhia das Letras, 2012, p. 13. A superação da náusea e da barbárie se dá com a organização de uma sociedade voltada a atender o interesse coletivo. A democracia ainda é o melhor dos regimes para identificarmos esse interesse, e o instrumento para tanto é o voto.

19 MARSHALL, Thomas H. Cidadania, classe social e status. Rio de Janeiro: Zahar, 1967.

20 Uma afirmação jusnaturalista que pontua que o indivíduo vem antes do Estado: “[...] a liberdade individual, no mundo moderno, não depende da pertença à comunidade, aliás, a precede e a condiciona.” BOVERO, Michelangelo. Contra o governo dos piores: uma gramática da democracia. Trad. Daniela B. Versiani. Rio de Janeiro: Campus, 2002, p. 126.

21 CLÈVE, Clèmerson Merlin. Direito constitucional, novos paradigmas, constituição global e processos de integração. In: BONAVIDES, Paulo; LIMA, F. G. M.; BEDÊ, Fayga S. (Coord.) Constituição e democracia: estudos e homenagem ao Prof. J.J. Canotilho. São Paulo: Malheiros, 2006, p. 23. 
Ainda de acordo com Clève, ${ }^{22}$ o problema na conceituação de Marshall está no termo status, isto é, na cidadania vista como um estado oferecido ao indivíduo, que nada precisa fazer para preservá-lo. Essa seria uma visão limitada e individualista, que, nos dias de hoje, precisa incorporar igualmente os direitos civis, sociais e econômicos, já que cidadania é um conceito em desenvolvimento, um processo em construção que precisa da participação integral dos cidadãos, na comunidade, para ser completado. ${ }^{23}$

O termo cidadania deve ser entendido, pois, como uma forma de se concretizar a soberania popular, não apenas no momento do voto, mas revendo a própria relação entre Estado e sociedade, garantindo ao povo a informação e a criação contínua de novos canais institucionais abertos para a participação social em geral.

A Constituição brasileira de 1988 está alinhada com esse conceito de cidadania participativa. Possui, dentre seus princípios fundamentais, ${ }^{24}$ a cidadania, expressando o compromisso de incluir os cidadãos nas atividades econômicas, sociais e políticas do Estado. Seu art. $5^{\circ}$ prevê vários dispositivos que promovem a participação política do cidadão na sociedade, como, por exemplo, o direito de petição (art. 5, XXXIV, “a”), mandado de injunção ( $\operatorname{art.} 5^{\circ}$, LXXI) e ação popular (art. 5, LXXIII). Já o caput de seu art. 14 prevê o sufrágio universal e o voto direto e secreto, bem como outros institutos de participação direta. E vários outros exemplos podem ser encontrados, ao longo do texto constitucional, realçando a concepção brasileira de cidadania.

Para que essa participação seja efetiva, é fundamental o amadurecimento político, resultado do próprio fortalecimento democrático, o qual proporciona transparência e debate sobre os novos rumos sociais. Já que democracia é, literalmente, poder do povo, quanto mais ela se fortalece, mais o povo se sente à vontade para se

22 CLÈVE, Clèmerson Merlin. Op. cit., p. 25.

23 Como observa Côrtes, “Ainda que Marshall (1967, 63-65, 73) tenha defendido a existência de uma sequência lógica para o desenvolvimento da cidadania, a partir da análise do caso da Inglaterra, onde primeiro surgiram os direitos civis, seguidos pelos políticos e finalmente pelos sociais, o autor via na educação uma exceção a essa sequência, garantindo que se trata de um pré-requisito necessário da liberdade civil.” CÔRTES, Lara Barbosa Quadros. Estado Federal e igualdade na educação básica pública. 2013. 269 f. Tese (Doutorado em Direito) - Faculdade de Direito, Universidade de São Paulo, São Paulo, 2013.

24 CF, art. 1º : A República Federativa do Brasil “[...] constitui-se em Estado Democrático de Direito e tem como fundamentos: I - a soberania; II - a cidadania; III - a dignidade da pessoa humana; IV - os valores sociais do trabalho e da livre iniciativa; V - o pluralismo político”. 
manifestar e se inteirar dos assuntos que lhe interessam. A necessidade de instituições e práticas ligadas à democracia política, como eleições periódicas, pluralismo, liberdade de expressão e de organização, imprensa livre etc., contribuem para a consolidação democrática. Mas não se pode deixar de lado a educação política, ${ }^{25}$ isto é, a criação de estímulos a essa participação, fazendo com que o povo compreenda a importância de votar, de escolher bem seus representantes, de exigir a execução dos programas políticos eleitos, tendo a iniciativa de criar novos espaços políticos para que suas reivindicações sejam ouvidas e atendidas.

A democracia está estruturada sobre os pilares da igualdade e da liberdade. E a liberdade, de acordo com Arendt, ${ }^{26}$ é liberdade para a participação política. Sem isso, seu sentido se esvai. E participar é escutar, ter acesso, materializar os direitos constitucionais, construir uma convivência coletiva baseada em um sentimento ético ${ }^{27}$ comum. Muito disso é alcançado pelo voto e o direito eleitoral que o alberga. Por isso, o estudo que se segue.

\subsection{Direito Eleitoral: sufrágio, eleitores, candidatos}

Democracia é poder do povo, que é o detentor supremo do poder, participando do processo político diretamente ou por meio de eleições, nas quais ele elege candidatos e partidos que o representarão no parlamento e que atuarão em prol de seus interesses na formação de uma sociedade livre e justa, com respeito aos direitos fundamentais. Com isso, ele é capaz de exercer um controle final sobre as decisões do governo e do parlamento.

25 A educação para a cidadania há séculos é defendida pelos mais importantes pensadores, destacandose John S. Mill, que na obra Governo Representativo, já aludia à educação formal dos indivíduos para o exercício da cidadania; ou Montesquieu, que, no "Espírito das Leis", tratou da necessidade de bom senso nas escolhas políticas; e, mais recentemente, Dahl defendeu a educação cívica como fundamental para a consolidação da democracia.

26 A política é o espaço “entre-os-homens”, lhes é externa, e o significado desse espaço é a liberdade. Por isso, argumenta que “[...] para as questões da Política, o problema da liberdade é crucial”. ARENDT, Hannah. Origens do totalitarismo: antissemitismo, imperialismo e totalitarismo. Trad. Roberto Raposo. São Paulo: Companhia das Letras, 2009, p. 191.

27 Sobre normas constitucionais e valor ético, recomenda-se a leitura do artigo "Sobre a origem das normas constitucionais: a identificação do campo-ético moral e sua relação com o Direito”, de Rubens Beçak. BEÇAK, Rubens; VELASCO, Ignácio M. P. (Org.). O Direito e o futuro da pessoa: estudos em homenagem ao prof. Antonio J. de Azevedo. São Paulo: Atlas, 2011, p. 16-28. 
Ao longo da história da humanidade, já foram desenvolvidos e expostos vários modelos democráticos. ${ }^{28}$ Para a presente análise, serão revistos autores que fizeram suas contribuições para o bom funcionamento democrático, enriquecendo o debate sobre o tema e promovendo a consolidação da democracia pautada no voto depositado nas urnas.

A definição minimalista de Schumpeter enfatiza:

A democracia é um método político, um tipo de organização institucional [...] resultante das decisões políticas, no qual os indivíduos adquirem o poder de pronunciar essas decisões após uma luta concorrencial tendo por objeto os votos do povo. ${ }^{29}$

Para o autor, os fatores sociais e culturais não eram relevantes, e a atenção recaía sobre a conduta dos atores políticos envolvidos nesse processo. A democracia era um método de seleção de líderes, uma mera competição que levaria à escolha dos mais sábios e competentes, estruturada em um pacto de curta duração, que pressupunha grande liberdade de imprensa e a atuação de uma burocracia tradicional e de prestígio, e que não tratava da manifestação ou participação popular depois do voto. Os dirigentes permaneciam no poder de forma pacífica e, se problema houvesse, seriam removidos também pelas urnas.

A vertente trazida por Robert Michels, na obra Sociologia dos partidos políticos, ${ }^{30}$ adotava igualmente a ideia de uma participação passiva. De acordo com o autor, a massa é incompetente, mas, felizmente, existem profissionais com superioridade intelectual e competência técnica, e a eles deve caber o poder. É um modelo que se justifica, porque os eleitos demonstram uma inquestionável superioridade técnico-racional. A lei de ferro da oligarquia, apesar das críticas que sempre recebeu, acerta ao identificar um espaço de saberes e práticas hermético e

28 Em dissertação defendida na Universidade Presbiteriana Mackenzie, foi feita uma análise abrangente dos vários tipos de democracia, desde os conceitos de Heródoto, passando pela democracia direta, representativa, participativa, até a definição de democracia eletrônica, objeto de estudo central do trabalho.

29 SCHUMPETER, Joseph. Capitalismo, socialismo e democracia. Rio de Janeiro: Zahar, 1967, p. 319320 e 355.

30 MICHELS, Robert. Sociologia dos partidos políticos. Brasília: Universidade de Brasília, 1982 (Coleção Pensamento Político, nº 53). 
hierarquizado, o qual, mesmo com a ampla liberdade de criação de partidos políticos, exclui vários desses grupos, limitando o número de vozes com representação nas urnas.

Samuel Huntington, ${ }^{31}$ por sua vez, aborda o tema seguindo os passos de Schumpeter, considerando a democracia um sistema político no qual os poderosos decisores coletivos são selecionados por meio de eleições justas, honestas e periódicas. Um enfoque também minimalista, baseado em eleições e, segundo o autor, suficiente para caracterizar esse sistema político. Regimes não-democráticos não possuem competição eleitoral nem ampla participação no voto e, assim, as eleições bastam para explicar o fortalecimento do regime democrático no mundo, com a presença de um grau de permeabilidade do sistema político às demandas sociais e sua capacidade de processamento.

Essa ampliação da democracia foi apresentada por Dahl, em 1971, na célebre obra Poliarquia, na qual ele demonstra que, ao longo do século XX, o número de países que se intitulam democráticos aumentou, apesar das diferenças existentes entre os eixos fundamentais de sua análise, isto é, institucionalização e participação. De fato, Dahl ${ }^{32}$ trata de um conceito mínimo de democracia, restrita a uma análise política, o que torna possível esses resultados.

Sem dúvida, o espírito democrático tem tomado o mundo de assalto, como também anunciado por Huntington, ${ }^{33}$ nas suas ondas democráticas. Nos anos 1990, pesquisadores argumentaram que a terceira onda democrática - que teve início, conforme Huntington, com a transição ocorrida em Portugal, em 1974 - havia atingido

31 HUNTINGTON, Samuel P. The third wave: democratization in the late twentieth century. Oklahoma: University of Oklahoma Press, 1991, p. 7: "Following in the Schumpeterian tradition, this study defines a twentieth-century political system as democractic to the extent that its most powerful collective decision makers are selected through fair, honest, and periodic elections in which candidates freely compete for votes and in which virtually all the adult population is elegible to vote."

32 DAHL, Robert. Polyarchy: participation and opposition. New Haven: Yale University, 1971. A célebre criação do termo "poliarquia" pelo professor norte-americano se baseia em atributos estabelecidos por Dahl e elencados nesse mencionado livro, dentre os quais autoridades eleitas, eleições livres e justas, sufrágio inclusivo, liberdade de expressão etc.

33 HUNTINGTON, Samuel. Op. cit., p.9: "Elections, open, free, and fair, are the essence of democracy, the inescapable sine qua non”. A questão eleitoral já havia sido sustentada por Schumpeter, anos antes, em seu Capitalismo, socialismo, democracia, afirmando que democracia é um sistema de decisão política pelo qual os indivíduos conquistam o poder de decidir, depois de passar por uma árdua competição pelo voto do eleitor. 
seu ápice. Lijphart ${ }^{34}$ apresenta estudo seminal sobre o tema, identificando, à época, trinta e seis democracias diversas, sendo que a base dessa conclusão era o aumento do número de eleições e sua frequência, ao redor do mundo. A entrada para o clube dos países democráticos era definida pelos pleitos eleitorais.

É bem verdade que não se pode garantir que, apenas por ter eleições, um país pode ser considerado democrático. Todavia, especialmente com as transições ocorridas no mundo no final do século passado, as eleições se tornaram um marco concreto, um objetivo tangível pelo qual trabalhar, aproximando os países da realização do sonho democrático, por trazer para o centro das discussões mecanismos como a participação política e a accountability, transformando a esfera pública em um espaço vibrante, na qual muitas visões dissonantes podem se expressar sem temor e que permitem aos cidadãos escolher entre projetos alternativos legítimos.

A síntese desse momento é feita por Caggiano:

Dentre os diferentes - e não muito afastados - conceitos doutrinários, de qualquer forma, emergem os elementos liberdade e igualdade a nortear os rumos democráticos e a sua concretização mediante eleições livres e competitivas com amplos espaços para oposição. Estes últimos valores, aliás, por muito tempo sustentaram o sufrágio universal como a conquista maior da humanidade. ${ }^{35}$

A democracia moderna, pois, é essencial e necessariamente representativa.

Ferreira Filho afirma:

No século XVII, contudo, inventou-se a democracia indireta ou representativa. Nesta o povo se governaria na medida em que escolhesse, em eleições livres, representantes que em seu nome e lugar deliberassem. [...] a democracia representativa não só foi consagrada pelo constitucionalismo como ainda é tida, hoje, como o modelo democrático por excelência. ${ }^{36}$

Por tudo isso, ganha relevância o Direito Constitucional Eleitoral.

34 LIJPHART, Arend. Modelos de democracia. Trad. Roberto Franco. 2 ed. Rio de Janeiro: Civilização Brasileira, 2008.

35 CAgGiAnO, Monica Herman Salem. Democracia X Constitucionalismo. Um navio à deriva? Disponível em: <http://www.cepes.org.br>. Acesso em: 22 jun. 2012.

36 FERREIRA FILHO, Manoel Gonçalves. Sete vezes democracia. São Paulo: Convívio, 1977, 18. 
Como leciona Canotilho, ${ }^{37}$ o conceito ideal de Constituição deve consagrar um sistema de garantias da liberdade e o princípio da divisão dos poderes, organizando o poder de forma a proteger os direitos dos cidadãos.

O Estado Democrático de Direito definido na Constituição Federal do Brasil está alicerçado nos direitos fundamentais da pessoa humana, ${ }^{38}$ nas suas diversas dimensões, e no princípio democrático. Ela traz, em seu conjunto de decisões políticas fundamentais, os contornos do Estado e da democracia, os direitos e garantias individuais e as regras de legitimação do exercício do poder político.

É no intuito de garantir a participação e a aplicação do sufrágio universal, a forma do voto, a distribuição do corpo eleitoral, dentre tantas outras regras e princípios, que exsurge o Direito Eleitoral, o qual somente pode ser reconhecido a partir do sistema constitucional positivo, nos termos e limites estabelecidos pelo processo constituinte e pela ordem democrática nacional.

O Direito Eleitoral organiza as regras e procedimentos que garantem o funcionamento do poder de voto, zelando para que as eleições sejam livres e justas (free and fair elections), preservando a escolha do eleitor. Essa liberdade na escolha do representante é fundamental para a democracia, por ser “[...] a concretização mais vigorosa da liberdade de manifestação do pensamento.”39

O Direito Eleitoral é, assim, instrumento a serviço da democracia e dá legitimidade e normalidade ao processo de deliberação popular. Além disso, a participação cidadã é fundamental para o aprimoramento da democracia. Quanto mais indivíduos participam das decisões políticas, mais capacitados se tornam para construir a sociedade da qual fazem parte.

O cenário de competição eleitoral só faz sentido em ambiente democrático. Não se pode confundir democracia com os regimes totalitários ou autoritários, que

\footnotetext{
CANOTILHO, J.J. Gomes. Direito Constitucional. Coimbra: Almedina, 1991.

38 Importante para a compreensão do tema é a obra de Claudio Lembo, A Pessoa: seus direitos, na qual o autor desenvolve estudo detalhado sobre os direitos fundamentais e suas gerações, traçando rebuscado painel histórico sobre os direitos da pessoa.

39 RIBEIRO, Fávila. Direito eleitoral. Rio de Janeiro: Forense, 1988, p. 268.
} 
dispensam totalmente o voto ou apenas o encenam, valendo-se dos mecanismos eleitorais para legitimar um cenário artificial.

Assim, no totalitarismo, o processo eleitoral é fictício, de fachada, não há competitividades, nem se confronta o poder dominante, pois a sociedade é tomada pelo medo e terror, ficando sem reação.

Nos climas autoritários, até existe um processo eleitoral, mas é um processo semicompetitivo, porque a disputa ocorre entre as facções do mesmo grupo. O nível de competitividade é extremamente baixo e não atende a uma fundamental cláusula das eleições democráticas: free and fair elections.

Huntington ${ }^{40}$ traça clara e sucinta diferença entre os sistemas totalitários e os autoritários. Os sistemas totalitários são formados por um só partido, geralmente comandados por um único homem; possuem uma polícia secreta eficiente e com força para agir; ideologia altamente desenvolvida para comandar a sociedade; penetração no governo e controle dos meios de comunicação de massa.

Os sistemas autoritários, por outro lado, são caracterizados por um líder ou por um pequeno grupo de líderes, sem mobilização das massas, talvez com uma mentalidade, mas nunca uma ideologia, pluralismo político limitado e sem nenhum esforço no sentido de se reconstruir a sociedade.

O ambiente democrático possui um processo eleitoral que legitima os detentores do poder político, por isso, esse cenário é tão importante, porque ele confere legitimidade ao poder, acobertado pelas eleições livres e justas, pelas quais os cidadãos podem premiar ou punir os candidatos ao poder, depositando seu voto contra ou a favor cada um deles. ${ }^{41}$

As lições de Caggiano são mais uma vez apontadas:

\footnotetext{
40 HUNTINGTON, Samuel. Op. cit., p. 12.

41 Nos termos de O’Donnel, essa seria a accountability vertical, verificada pelas eleições periódicas. Destaca, porém, que nem sempre essa prestação de contas é eficaz, em função dos "sistemas partidários pouco estruturados, alta volatilidade de eleitores e partidos, temas de política pública pobremente definidos, e reversões políticas súbitas”. O’DONNELL, Guillermo. Accountability horizontal e novas poliarquias. Lua Nova, São Paulo, n. 44, p. 29, 1998.
} 
[...] o poder de sufrágio, exercido por via eleitoral, consagra, como anotado por Sartori, a garantia mecânica das práticas democráticas [...] quando desenvolvido o sistema de molde a se acomodar ao macroprincípio da autodeterminação e seus corolários a seguir: atribuição igual do direito de voto e sufrágio universal; periodicidade do voto; igualdade do valor do voto; sigilo do voto; liberdade de postular cargos eletivos; direito dos candidatos de disputarem respaldo popular; direito dos líderes políticos e candidatos de disputarem votos. $^{42}$

O voto é, pois, parte essencial desse processo democrático.

A Constituição Federal de 1988 apresenta, em seu Título II, os direitos e garantias fundamentais, que estão divididos em cinco capítulos: direitos individuais e coletivos, direitos sociais, nacionalidade, direitos políticos e partidos políticos.

Afirma-se que existem os direitos de primeira, segunda e terceira geração, ${ }^{43}$ havendo, ainda, autores que tratam dos direitos de quarta e quinta geração ${ }^{44}$.

A primeira geração de direitos está fundamentada na liberdade e corresponde aos direitos civis e políticos, dentre os quais o direito ao sufrágio, isto é, o direito de participar da decisão política.

Os direitos de segunda geração relacionam-se às liberdades positivas, com a fixação dos direitos sociais, que resultaram da luta do proletariado por melhorias essenciais na saúde, alimentação, educação. São direitos que exigem uma atuação estatal para sua implementação concreta e foram reconhecidos já no início do século XX, nas Constituições do México (1917) e de Weimar (1919).

42 CAGGIANO, Monica Herman Salem. Direito eleitoral e direito parlamentar. Barueri: Manole, 2004, p. 80.

43 A divisão das dimensões tem por base o lema da Revolução Francesa: liberdade (1 ${ }^{a}$ geração), igualdade ( $2^{\mathrm{a}}$ geração) e fraternidade ( $3^{\mathrm{a}}$ geração).

44 Norberto Bobbio, em A era dos direitos, entende que os direitos de quarta geração se referem à biotecnologia e bioengenharia, ou seja, à pesquisa biológica que manipula o patrimônio genético. Paulo Bonavides, em seu Curso de direito constitucional, associa esse direito à informação e ao pluralismo, e à problemática trazida pela globalização. Antônio Carlos Wolkmer, em seu livro Introdução aos fundamentos de uma teoria geral dos "novos" direitos classifica a cibernética e a Internet como direitos de quinta geração. Hugo Hoeschel, em $O$ conflito e os direitos da vida digital, fala em direitos de sexta e sétima gerações ao se referir à cibernética e biogenética. Como se vê, não há consenso na doutrina sobre a definição dessas gerações de direitos. Entendemos que o cerne da classificação dos direitos fundamentais deve se ater aos direitos civis, sociais e políticos, e não aos avanços tecnológicos. Assim, o direito ao sigilo bancário por ser lido como direito de primeira geração, e os direitos da coletividade presente na rede virtual seriam direitos de terceira geração. 
Os direitos de terceira geração consagram os princípios da fraternidade, protegem interesses de titularidade coletiva ou difusa e são fruto das transformações trazidas pela revolução nos meios de comunicação e de transportes.

José Murilo de Carvalho ${ }^{45}$ evidencia uma interpretação já consagrada na academia, e demonstra que, no Brasil, houve uma inversão na evolução desses direitos. Assim, primeiro vieram os direitos sociais, seguidos dos direitos políticos, e a sociedade ainda busca ampliar os direitos civis para toda a população, já que, a fim de se atingir cidadania plena, é fundamental que sejam assegurados, na mesma medida, os direitos fundamentais.

O fortalecimento dos direitos civis e políticos torna-se essencial para a implementação de uma cidadania segura e duradoura, por isso, a ênfase dada ao sufrágio, que “[...] é um direito público subjetivo de natureza política que tem o cidadão de eleger, ser eleito e de participar da organização e da atividade do poder estatal.”46

Petit ${ }^{47}$ aponta que a visão republicana sobre cidadania e sobre governo se baseia na noção de confiança e no dever do governo em promover a liberdade dos cidadãos.

Benjamin Constant ${ }^{48}$ ressalta a diferença que há entre a liberdade dos antigos e a liberdade dos modernos. A liberdade dos antigos é o direito de participar da decisão política; o indivíduo era livre, à medida que ele produzia ingerência no poder, efetivamente influenciando a decisão política. Já na liberdade dos modernos, o indivíduo é livre, se o detentor do poder político não tiver o direito de exigir dele essa

45 "A cronologia e a lógica da sequência descrita por Marshall foram invertidas no Brasil. Aqui, primeiro vieram os direitos sociais, implantados em período de supressão dos direitos políticos e de redução dos direitos civis por um ditador que se tornou popular. Depois vieram os direitos políticos, de maneira também bizarra. A maior expansão do voto deu-se em outro período ditatorial, em que os órgãos de representação política forma transformados em peça decorativa de regime. Finalmente, ainda hoje muitos direitos civis, a base da sequência de Marshall, continuam inacessíveis à maioria da população. A pirâmide dos direitos foi colocada de cabeça para baixo.” CARVALHO, José Murilo de. Cidadania no Brasil: o longo caminho. Rio de Janeiro: Civilização Brasileira, 2002, p. 219/220.

46 MORAES, Alexandre de. Direito Constitucional. São Paulo: Atlas, 2001, p. 228.

47 PETIT, Philip. Republican theory and political trust. In: BRAITHWAITE, Valerie; LEVI, Margaret (Ed.). Trust and governance. New York: Russell Sage Foundation, 1998, p. 295-314.

48 CONSTANT, Benjamin. Liberdade dos antigos x liberdade dos modernos. Trad. António de Araújo. Coimbra: Tenacitas, 1983. 
ingerência. É o Estado minimalista. Quanto menor a interface entre Estado e poder, maior a liberdade do cidadão.

Cada vez mais a liberdade se vê assegurada se presentes as seguintes condições: o Estado preservando a autonomia do indivíduo e abrindo espaço para a influência exercida por diversos grupos. A partir do momento em que se constata que as minorias possuem os instrumentos adequados para tomar parte na tomada de decisão política fundamental, pode-se afirmar que há o fortalecimento da cidadania e da democracia.

Estabelece a Constituição brasileira de 1988, art. 14: “A soberania popular será exercida pelo sufrágio universal e pelo voto direto e secreto, com valor igual para todos”. Fica claro que sufrágio difere de voto, sendo o primeiro o direito de votar e de ser votado, e o segundo, a forma como é exercido o direito ao sufrágio.

$\mathrm{O}$ art. $14, \S 1^{\circ}$, determina que o alistamento eleitoral e o voto são obrigatórios ${ }^{49}$ para os maiores de 18 anos e facultativos para os analfabetos, os maiores de 70 anos, e maiores de 16 e menores de 18 anos. A CF/88, pois, ampliou o corpo eleitoral e reduziu a idade mínima para o exercício do direito de voto.

Walter Costa Porto ${ }^{50}$ escreveu importante trabalho sobre a história do voto, no Brasil, fazendo uma análise que começa no período colonial e se estende até a $6^{\text {a }}$ República. Assim, inicia o autor sua pesquisa, afirmando: “Antes de 1822, o Brasil conheceu, somente, eleições para os Conselhos ou Câmaras", ${ }^{51}$ o que equivaleria às Câmaras municipais de agora.

A primeira eleição geral no país se deu em 1821 e foi conduzida de forma complexa, em quatro graus, para a designação dos deputados às Cortes de Lisboa. A fórmula foi ditada pela Constituição espanhola de Cadiz, fixando que juntas eleitorais

\footnotetext{
49 O voto obrigatório foi implantado no Brasil com o Código Eleitoral de 1932 e transformado em norma constitucional, em 1934.

50 PORTO, Walter Costa. O voto no Brasil. Rio de Janeiro: Topbooks, 2002.

51 PORTO, Walter Costa. Op. cit., p. 11.
} 
de freguesia indicariam as juntas de comarca, e estas apontariam as juntas de partido, que, por sua vez, designariam os deputados. ${ }^{52}$

O sufrágio indireto continuou prevalecendo na Constituição de 1824, que manteve o processo eleitoral em dois graus, empregando os seguintes termos para tratar dos eleitores:

[...] no segundo grau, os Eleitores de Paróquia ou, simplesmente, Eleitores; referiam-se, no primeiro grau, genericamente, "a cada um dos moradores da Freguesia, que tem direito de votar". [...] quanto ao primeiro grau, falava somente da "massa dos cidadãos ativos".

A expressão Votante, para caracterizar o eleitor de primeiro grau, viria somente com o Decreto 157, de 4 de maio de 1842. Mas já as discussões no Parlamento e nos relatos de imprensa se utilizavam largamente as denominações de Votantes e Eleitores para definir os atores da cena eleitoral. ${ }^{53}$

Votavam no Município os homens maiores de 25 anos e livres. Importante lembrar que $30 \%$ da população era escrava, ${ }^{54}$ e os escravos eram tidos como "coisas”, excluídos da categoria de sujeitos de direitos. Os eleitos nos Municípios tornavam-se os eleitores da esfera provincial (que equivaliam aos Estados) e da esfera nacional. ${ }^{55}$ Durante toda a fase do Império, o voto era censitário, e o art. 94 da primeira Constituição brasileira instituiu a renda mínima anual de 200 mil-réis para tanto.

A Constituição de 1824 tinha início com a frase: “O Império do Brasil é a associação política de todos os cidadãos brasileiros”. Entretanto, aqueles que podiam votar eram a exceção, no Brasil da época, ou seja, o país nasce com uma organização política antidemocrática.

52 PORTO, Walter Costa. Op. cit., p. 22.

53 PORTO, Walter Costa. Op. cit., p. 44.

54 O Brasil foi o país da América Latina no qual a escravidão durou mais tempo, tendo sido abolida por completo somente em 1888. Vale mencionar, porém, algumas leis e acontecimentos que pressionaram pela abolição, como a Lei Eusébio de Queirós (1850), a Guerra do Paraguai (18641870), a Lei Rio Branco (1871) e a Lei Saraiva-Cotegipe (1885).

55 VILLA, Marco Antonio. A história das constituições brasileiras. São Paulo: Leya, 2011, p. 17. 
A Lei dos Círculos (Lei $n^{\circ}$ 842/1855) é o instituto a introduzir o voto distrital ${ }^{56}$ no Império, que “[...] dividiu as províncias em distritos de um só deputado e mandou eleger os suplentes de deputados na mesma ocasião que estes, em ato sucessivo”. ${ }^{77}$ Sua intenção era dar espaço para as, nas Assembleias, mas seus resultados deploráveis, que provocavam a proximidade e identificação dos candidatos com os dominadores de cada localidade, ${ }^{58}$ fizeram com que ela fosse logo reformada.

Seguiu-se a Lei $n^{0}$ 1.082/1860, denominada Segunda Lei dos Círculos, que alargava os distritos eleitorais, e a Lei $n^{\circ} 2.675 / 75$, ou Lei do Terço, que visava a garantir a representação das minorias com base na ideia de que "[...] a terça parte da representação, não sufragada nas cédulas da maioria, pelas correntes minoritárias”. 59

Esse instituto foi, no mesmo sentido, logo burlado e não resistiu aos clamores pelo voto direto, ${ }^{60}$ adotado pela Lei Saraiva, em 1881. De acordo com Porto, José Bonifácio discursou, à época:

Segundo ele [José Bonifácio], a pirâmide do poder estava, em nosso país, invertida, assentada sobre o vértice, em vez de assentada sobre a base: o poder executivo era tudo. À eleição direta cabia, então, colocar a pirâmide em seu lugar. ${ }^{61}$

Assim, ainda durante o Império, foi promulgada a Lei Saraiva, que objetivava reforçar a necessidade de ampliação do corpo eleitoral, de forma a deixá-lo mais próximo do real número da população brasileira de então. Com essa lei, o voto passava a ser direto, mas continuava sendo censitário, exigindo-se 200 mil-réis para poder ser eleitor. Além disso, manteve-se a exclusão dos analfabetos. A orientação continuou sendo elitista e muitos permaneciam de fora da eleição. Nas palavras de Carvalho: “[A

56 O voto distrital foi introduzido no Brasil pelo Decreto 842, de 19 de setembro de 1855, e vigorou até 1930.

57 LEAL, Victor Nunes. Coronelismo, enxada e voto: município e o regime representativo no Brasil. 7. ed. São Paulo: Companhia das Letras, 2012, p. 208

Porto ressalta a análise de Maurice Duverger sobre o voto distrital, que abordava a "brutalidade" desse modelo de voto, em sua obra Sociologia Política. PORTO, Walter Costa. Op. cit., p. 73.

59 LEAL, Victor Nunes. Op. cit., p. 209.

60 Porto reproduz, ao tratar da Lei do Terço, trecho do artigo de José de Alencar: "Temos experimentados círculos, triângulos, diversas formas de manipulação, falta a eleição direta; é o travesseiro para o enfermo que não tem repouso.” In: PORTO, Walter Costa. Op. cit., p. 95.

61 PORTO, Walter Costa. Op. cit., p. 101. 
Lei saraiva] criava uma orientação política sem sujeito, um sistema representativo sem povo". 62

A Lei Saraiva exigiu o alistamento e instituiu o título de eleitor que, entretanto, não continha a foto do eleitor, o que, por óbvio, colocava em dúvida a legitimidade do processo eleitoral. Mesmo assim, observa Caggiano que o alistamento provocou outros efeitos: “(1) a legitimação da condição de eleitor; (2) identifica-se o domicílio do eleitor, (o que) fixa o local do exercício do voto e delimita o local onde o cidadão poderá concorrer a cargos eletivos, exercendo a cidadania na sua segunda faceta.”63

No ano de 1889, a República é proclamada e, em 1891, o Brasil tem sua segunda Constituição, ou a primeira Constituição republicana brasileira, ${ }^{64}$ com inspiração no modelo norte-americano. Foram abolidas as principais instituições monárquicas, como o Poder Moderador, e introduzido o sistema de governo presidencialista. A eleição do presidente da República passou a ser pelo voto direto, ${ }^{65}$ apesar das várias manifestações em contrário, como a de Ruy Barbosa. ${ }^{66}$ Eram eleitores os brasileiros do sexo masculino, ${ }^{67}$ maiores de 21 anos, excluídos, dentre outros, os analfabetos, que representavam grande parte da população acima dessa faixa etária.

A década de 1920 é marcada pelas revoluções tenentistas e, ainda, pelos problemas econômicos mundiais que levaram à crise de 1929. Washington Luís assume a presidência, em 1930, mas, sete meses após a eleição, teve início a Revolução de 30,

62 CARVALHO, José Murilo de. Op. cit.. p. 39.

CAGGIANO, Monica Herman Salem. Op. cit., p. 82.

Preâmbulo e trechos da <http://cpdoc.fgv.br/producao/dossies/AEraVargas1/anos20/CrisePolitica/Constituicao1891>. Acesso em: 12 ago. 2013

65 Ressalta-se que a primeira eleição presidencial que aconteceu um dia após a proclamação da Constituição foi indireta, e elegeu Deodoro da Fonseca para o cargo. A primeira eleição presidencial direta ocorreu apenas em 1894, e teve a participação de 2,2\% da população. CARVALHO, José Murilo de. Cidadania no Brasil: o longo caminho. 10. ed. Rio de Janeiro: Civilização Brasileira, 2008, p. 40.

66 SARASATE, Paulo. A Constituição do Brasil ao alcance de todos. Rio de Janeiro: Freitas Bastos, 1967, p. 105. O autor explica que a disputa foi acirrada, vencendo o voto direto por uma diferença de 5 votos.

67 As mulheres só votariam anos mais tarde, mas o voto feminino era defendido por Machado de Assis: "Elevemos a mulher ao eleitorado; é mais discreta que o homem, mais zelosa, mais desinteressada [...] convidemo-la a colaborar com o homem na oficia da política”. ANDRADE, Gentil. Pensamentos e reflexões de Machado de Assis. Rio de Janeiro: Civilização Brasileira, 1990, p. 114. 
que coloca Getúlio Vargas no poder, cujo governo, chamado de "provisório”, prometeu convocar uma Assembleia Constituinte, além de eleições, que só foram marcadas para maio de 1932, por meio de um decreto de Vargas. O clima de tensão instaurado com essa possibilidade de restabelecimento da legalidade constitucional, já que os tenentistas temiam perder o poder conquistado com o movimento de 30, culminou na Revolução Constitucionalista de 1932.

Como bem ressalta Marco Antonio Villa:

Apesar de tudo, a guerra civil acabou levando à confirmação da realização das eleições para a Constituinte em 3 de maio de 1933. Pela primeira vez as mulheres puderam votar em todo o país. O Brasil era o quarto país das Américas a conceder o voto às mulheres, depois do Canadá, Estados Unidos e Equador. Apesar da vitória histórica, no Rio de Janeiro, apenas 15\% doe eleitores registrados eram mulheres. Foram eleitas duas mulheres: uma pelo voto direto e a outra como representante classista.

Foi criada a Justiça Eleitoral e adotado o voto secreto. Dos 254 constituintes, 40 foram indicados: 20 pelos sindicatos e outros20 por entidades representativas do empresariado. Dos 214 eleitos, a distribuição foi quase idêntica à de 1890, apesar do crescimento populacional [...]. As três maiores bancadas continuaram a ser as de Minas Gerais (37), de São Paulo e da Bahia (22 cada uma). ${ }^{68}$

Além das inovações trazidas com o voto feminino e a representação proporcional, deve-se frisar que o Código Eleitoral de 1932 tentou moralizar o processo eleitoral, centralizando-o nos órgãos recém-criados, quais sejam, o Tribunal Superior Eleitoral e os Tribunais Regionais Eleitorais. A Justiça Eleitoral, com isso, ficou encarregada de todo o processo de alistamento, apuração dos votos e proclamação dos eleitores, acabando com as distorções cometidas pela política local.

O Código Eleitoral valorizou as ideias propostas pelo eminente professor Assis Brasil, que dedicou muito de seus estudos para o aprimoramento do modelo eleitoral no país. Seu livro A democracia representativa faz a defesa da representação e do critério da proporcionalidade, oferecendo, além disso, fundamentos para a adoção do sufrágio universal, “[...] um direito iniludível do indivíduo e [...] imperiosa condição de ordem e

68 VILLA, Marco Antonio. A história das constituições brasileiras. São Paulo: Leya, 2011, p. 47. 
progresso", ${ }^{69}$ das listas partidárias abertas e do voto nominal (um dos fatores de enfraquecimento dos partidos políticos).

Destaque merece ainda sua obra, ao tratar do importante princípio "one man, one vote”. ${ }^{70}$ Assis Brasil condena a desigualdade do voto e afirma que cada cidadão pode depositar apenas uma cédula na urna, já que “[...] a verdade é que a igualdade do voto é a melhor garantia da desigualdade natural das influências.”71

Segue-se uma fase de poucas inovações, nessa área de estudo. A Constituição de 1946 remete ao Código Eleitoral de 1932 e, depois disso, sobreveio o regime autoritário instituído pelo golpe militar, que foge do escopo desta tese, exatamente por implementar eleições artificiais, sem competitividade.

Em 1985, a Emenda Constitucional $n^{0} 25$ devolve aos analfabetos a capacidade política que a Constituição de 1891 lhes havia negado. Além disso, fixa o número de deputados federais por Estado, entre 8 e 60 (mínimo e máximo, respectivamente), o que, com a Constituição de 1988, é alterado para o teto de 70 em cada circunscrição, como estabelece o art. 45 , $\S 1^{\circ}$.

A ideia da democracia representativa é a de que governos são eleitos pelo voto popular e representam aqueles que neles votaram. Os candidatos oferecem propostas políticas e a população estuda essas plataformas, selecionando aquelas que querem ver implementadas. Para Przeworski, ${ }^{72}$ a função do voto é exatamente reunir essas preferências do eleitor para eleger o governo, que colocará essas medidas em prática, atendendo aos interesses e bem-estar da população. A força de seu ideal mantém o modelo vivo.

69 BRASIL, Joaquim Francisco de Assis. A democracia representativa na república - antologia. Brasília: Conselho Editorial do Senado Federal, 1998, p. 73.

70 Como explica Caggiano, a fórmula “each person is to receive one, and only one vote” foi celebrizada pelo julgamento do caso "Baker X Carr” nos Estados Unidos. CAGGIANO, M. H. Salem. Do direito de sufrágio ativo. Do corpo Eleitoral. In: CAGGIANO, Monica Herman Salem (Coord.); MESSA, Ana Flávia; ALMEIDA, Fernanda Dias Menezes de. Direito eleitoral em debate: estudos em homenagem a Cláudio Lembo. São Paulo: Saraiva, 2013, p. 81.

71 BRASIL, Joaquim Francisco de Assis. Op. cit., p. 122.

72 PRZEWORSKI, Adam. Minimalist conception of a democracy. In: SHAPIRO, Ian; CORDÓNHACKER, Cassiano (Ed.). Democracy's value. Cambridge: Cmbridge University Press, 1999. 
O estudo da operação eleitoral perpassa, portanto, pela análise dos eleitores e candidatos.

A Carta de 1988 devolveu a capacidade eleitoral para o analfabeto. A interdição de seu voto ocorria desde a lei imperial de 1881 (Lei Saraiva), que estabeleceu o “censo literário”, proposto por Ruy Barbosa, exigindo que o eleitor soubesse ler e escrever. A Constituição republicana de 1891 manteve o veto e foi somente com a promulgação da Emenda Constitucional $\mathrm{n}^{0} 25$, de 1985, que os analfabetos recuperaram seu direito de voto, facultativo, o que foi mantido pela Constituição de 1988.

A ampliação da capacidade eleitoral ativa ${ }^{73}$ ganhou força no período republicano, com movimentos que defendiam o voto secreto e o voto feminino, que foi autorizado com o advento do Código Eleitoral (Decreto n. 21.076/32), mas com restrições, pois exigia renda própria. Foi apenas a Constituição de 1934 que assentou esse direito em base constitucional, contudo, a restrição se mantinha, pois só podiam votar as mulheres que exerciam função pública remunerada. Villa assinala que, com a Carta de 1934,

Ficou definido que a eleição presidencial seria "por sufrágio universal, direto e secreto". Pela primeira vez as mulheres poderiam votar para presidente. Pena que isso só ocorreu em 1945, 11 anos depois, tendo em vista que as eleições de 1938 não ocorreram por causa do golpe do Estado Novo, em novembro de $1937 .^{74}$

Durante os sombrios anos do Estado Novo (1937-1945), houve o fechamento do Congresso e o brasileiro não exerceu direito de voto. O mesmo se deu com o golpe militar de 1964, que proibiu o voto direto para Presidente da República.

E é somente com a Constituição de 1946 que o direito de voto é ampliado a todas as mulheres, segundo o disposto em seu art. 131.

De acordo com o site do Tribunal Superior Eleitoral, atualmente,

\footnotetext{
73 Aquela que garante ao nacional o direito de votar nos pleitos eletivos, assunto que será abordado mais adiante com mais detalhes, ainda neste capítulo.

74 VILLA, Marco Antonio. Op. cit., p. 57.
} 
[a]lém da Presidência da República, exercem mandato duas governadoras, 11 senadoras, 45 deputadas federais e 134 deputadas estaduais.

Do total de eleitos em 2012, 8.287 foram mulheres, representando 13,19\%. Ao todo, foram eleitas 657 prefeitas, que correspondem a $11,84 \%$ do total das 5.568 vagas, e 7.630 vereadoras, o que equivale a $13,32 \%$ dos eleitos. ${ }^{75}$

Isso representa um crescimento de 12,2\% em relação a 2008.

As condições de elegibilidade estão elencadas na Constituição Federal, art. 14, $\S 3^{\circ}$. O mesmo art. 14 , no $\S 4^{\circ}$, determina serem inelegíveis os inalistáveis ${ }^{76}$ e os analfabetos, sendo possibilitado à lei complementar a extensão e a ampliação de novas hipóteses caracterizadoras de inelegibilidade, dentro dos parâmetros constitucionais. ${ }^{77}$

As mudanças trazidas na configuração da cidadania política, no Brasil, apenas reforçam o caráter democrático dessa Constituição cidadã e o espírito republicano que pressupõe a virtude e a confiança, tanto nos cidadãos como em seus representantes.

É possível aproximar esses valores com o modelo apresentado por Tocqueville, ao fazer sua jornada pela América. O ideal republicano reflete o valor da igualdade. E, aos olhos de Tocqueville, a democracia consiste na igualdade de condições. O teórico esteve atento aos princípios de organização da comunidade política e percebeu que os americanos construíam e viviam suas instituições de uma forma duradoura, uma vez que só o tempo conseguiria cristalizar as conquistas obtidas com a democracia. A política americana era um exercício diário, o que contribuía para que não houvesse pessoas consideradas intelectualmente superiores a outras. ${ }^{78}$

75 Disponível em: <http://www.tse.jus.br/noticias-tse/2013/Abril/serie-inclusao-a-conquista-do-votofeminino-no-brasil>. Acesso em: 26 out. 2013.

76 Inalistáveis são aqueles que não podem se alistar como eleitores, por exemplo, os estrangeiros, ou os conscritos, durante o período de serviço militar obrigatório.

77 Com base nisso foi aprovada a Lei Complementar $n^{\circ}$ 135/10, ou "Ficha Limpa", que alterou as causas de inelegibilidade antes explicitadas na Lei Complementar n 64/90. A análise dessas novas hipóteses será feita em momento posterior.

78 “[...] a colônia apresentava, cada vez mais, o espetáculo novo de uma sociedade homogênea em todas as suas partes. [...] Não creio que haja país no mundo em que, proporcionalmente à população, se encontrem tão poucos ignorantes e menos sábios do que na América. A instrução primária está ao alcance de todos; a educação superior não está ao alcance de quase ninguém. [...] Os americanos só podem, portanto, dar os primeiros anos de vida ao cultivo geral da inteligência. Não existe, portanto, 
Essa soberania popular cotidianamente exercida torna-se quase um princípio sagrado, que é percebido por todos os cidadãos e se perfaz em uma cultura política exemplar. Tocqueville enfatiza:

O povo participa da composição das leis [...] e de sua aplicação; podese dizer que governa diretamente, tanto é fraca e restrita a parte que toca à administração, tanto essa se ressente de sua origem popular e obedece ao poder de que emana. O povo reina sobre o mundo político americano como Deus sobre o universo. ${ }^{79}$

Um século depois, Gabriel Almond e Sidney Verba analisam o sistema democrático em cinco países - Estados Unidos, Alemanha, México, Itália e Reino Unido - e identificam suas estruturas políticas e cultura cívica, formando esses dois fatores o princípio inicial de suas análises e o padrão que deve ser buscado pelas nações. A democracia americana serve como exemplo dessa cultura, um parâmetro pelo qual se verifica o sistema político adotado. Para reter essa cultura política, são necessárias instituições dos mais diversos modelos, como a escola, a família, instituições voluntárias e de trabalho. ${ }^{80}$

Com essa breve relação, o que se quer afirmar é que, ao longo do tempo, vários analistas têm tratado da análise da democracia, seus institutos, suas variantes, mas parece ficar claro que a evolução contínua da democracia exige a participação cada vez mais intensa e vigorosa dos membros de dada comunidade, com o respeito às opiniões contrárias e com um povo que se autodetermine e se reformule. ${ }^{81}$ Devem-se

na América, classe em que a inclinação para os prazeres intelectuais se transmita com familiaridade e disponibilidade hereditárias e que tenha os trabalhos da inteligência em autoestima [...] estabeleceuse na América, nos conhecimentos humanos, certo nível mediano. TOCQUEVILLE, Alexis de. A democracia na América: leis e costumes de certas leis e certos costumes políticos que foram sugeridos aos americanos por seu estado social democrático. Livro I. Trad. Eduardo Brandão. 2 ed. São Paulo: Martins Fontes, 2005, p. 196-200.

79 TOCQUEVILLE, A. de. Op. cit. p. 202.

"Nossos dados têm demonstrado a educação ser o mais importante determinante das atitudes políticas; e também o mais manipulável. A grande vantagem da educação é que habilidades que podem levar anos para desenvolver pela primeira vez podem ser transmitidas muito mais facilmente sempre que haja alguém que as transmitia.” ALMOND, Gabriel; VERBA, Sidney. The civic culture. Political atitudes and democracy in five nations. USA: Little Brown and Company, 1965, p. 370.

81 Habermas trata da autodeterminação e da participação cidadã como condicionantes da transição para o Estado democrático de direito: “[...] o Estado moderno tem duas marcas constitutivas: a soberania do pode estatal [...] e a diferenciação do Estado em relação à sociedade. Com a mudança da soberania baseada no príncipe para a de cunho popular, esses direitos dos súditos transformam-se em direitos do homem e do cidadão, ou seja, em direitos liberais e políticos de cidadania. Do ponto de vista de uma tipologia ideal, tais direitos garantem não só a autonomia privada, mas também a autonomia política, que em princípio é atribuída com igualdade a cada um.” HABERMAS, Jurgen. A inclusão 
proporcionar formas de estimular a participação cidadã e a cultura cívica, para que os cidadãos se sintam capazes de discutir livremente os rumos que desejam tomar. Para Aristóteles, o melhor governo é “[...] aquele no qual cada um encontre a melhor maneira de ser feliz.” ${ }^{2}$ Cabe ao povo a eterna vigilância que, nesta tese, se defende seja facilitada e aprimorada pelos instrumentos disponibilizados na Internet. Fica aqui a reflexão de Santos:

\begin{abstract}
A luta pela cidadania não se esgota na confecção de uma lei ou da Constituição porque a lei é apenas uma concreção, um momento finito de um debate filosófico sempre inacabado. Assim como o indivíduo deve estar sempre vigiando a si mesmo para não se enredar pela alienação circundante, assim o cidadão, a partir das conquistas obtidas, tem de permanecer alerta para garantir e ampliar sua cidadania. ${ }^{83}$
\end{abstract}

\title{
1.2 Tratamento legal brasileiro
}

\section{Conforme lição de Assis Brasil:}

A lei eleitoral tem por fim estabelecer regras para que todos os que possam conscientemente votar votem ao abrigo da fraude e da violência; dessa concorrência de capacidades e influências mais ou menos culminantes, mais ou menos definidas, nascerá forçosamente a média do pensamento nacional. Bom ou mau o resultado, ele deve ser aceito, como o único natural, pois, legítimo.

Fica evidente, assim, que as normas do jogo eleitoral são essenciais para a configuração de um Estado democrático, por traçar as regras e princípios a serem obedecidos para tornar concreta a representação política, base operacional da democracia. O Direito Eleitoral reúne essas normas, estabelecendo o legítimo processo de escolha dos representantes, condição necessária para a avaliação da qualidade da democracia. Flávia Ribeiro muito bem aponta que o Direito Eleitoral se dedica “[...] ao estudo das normas e procedimentos que organizam e disciplinam o funcionamento do

do outro. Estudos de teoria política. Trad. George Sperber, Paulo Astor Soethe e Milton Camargo Mota. 3. ed. São Paulo: Loyola, 2007, p. 135.

82 ARISTÓTELES. A política. São Paulo: Martins Fontes, 1998, p. 59.

83 SANTOS, Milton. O espaço do cidadão. 7. ed. São Paulo: EDUSP, 2007, p. 105. 
poder de sufrágio popular, de modo que se estabeleça a precisa equação entre a vontade do povo e a atividade governamental." 84

Cláudio Lembo ${ }^{85}$ apresenta eloquente trabalho sobre a legislação brasileira que versa sobre Direito Eleitoral, desde 1532, com as Ordenações Manuelinas, que estipulavam, à época, “[...] em que modo se fará a eleição dos juízes, vereadores e outros oficiais”, até 1966, com as alterações ao Código Eleitoral do ano anterior. Depreende-se que, desde sempre, as regras eleitorais se sucederam de forma constante, ${ }^{86}$ sem muita sistematização, o que se reflete, nos dias de hoje, em leis muito criticadas e reiterados apelos por reforma eleitoral.

Além da Constituição Federal, vários outros diplomas legais foram aprovados, no sentido de promover disputas eleitorais estáveis, muitos deles tendo sido complementados ou interpretados por resoluções do Tribunal Superior Eleitoral, que, ao se valer do argumento de que está adaptando a lei a uma eleição específica, acaba por inovar a ordem jurídica nacional.

Assim, as normas do direito eleitoral brasileiro decorrem dessas três vias: Constituição Federal, legislação (complementar e ordinária) e resoluções do Tribunal Superior Eleitoral. Esse é o motivo dos tópicos a seguir.

\subsubsection{Constituição Federal de 1988}

A construção de uma democracia representativa tem início na opção constitucional pelo princípio representativo. Depois de adotado, a consequência prática é o estabelecimento de um parlamento, cujos membros serão escolhidos por meio de uma eleição. Desse modo, a Constituição Federal é o documento primordial para a organização da matéria eleitoral, o que é seguido pela Carta Magna brasileira, que

84 RIBEIRO, Fávila. Direito Eleitoral. Rio de Janeiro: Forense, 1976, p. 12.

85 LEMBO, Claudio. Cronologia básica do Direito Eleitoral Brasileiro. In: LEMBO, Cláudio; CAGGIANO, Monica Herman S. (Coord.). O voto nas Américas. Barueri, SP: Minha Editora; São Paulo: Cepes, 2008, p. 73-106.

86 Reale, em 1959, atestava o fato: “[...] no Brasil o Direito Eleitoral revela alto índice de experiências malogradas, renovando-se medidas ontem consideradas obsoletas, e envelhecendo em poucos meses as mais alvissareiras novidades.” REALE, Miguel. O sistema de representação proporcional e o regime presidencial brasileiro. Revista Brasileira de Estudos Políticos, Belo Horizonte, n. 7, p. 24, nov. 1959. 
consagra princípios fundamentais a serem observados pelos sistemas eleitoral e partidário do Brasil.

Estampados em seu art. $1^{\circ}$, estão o princípio republicano, que consagra o país como uma República Federativa, constituída pela união indissolúvel de Estados, Municípios e Distrito Federal; o princípio democrático, na singela explicação do poder do povo; o princípio da soberania popular, pelo qual o poder emana do povo; e o princípio do pluralismo político, que será analisado em capítulo adiante.

A soberania popular é um dos princípios mais importantes do direito eleitoral. A eleição deve ser uma expressão da opinião do povo, e o resultado das eleições precisa ser legítimo, uma representação fiel da vontade popular.

Para tanto, o voto deve ser livre. O eleitor tem o direito de votar em quem desejar, e não pode ser vítima de violência ou abuso de poder. O direito ao voto está previsto como um direito fundamental do cidadão, e não pode ser alterado nem por reforma constitucional (art. 60, $\S 4^{\circ}$, II), devendo ser direto, secreto e universal.

O art. 14 da CF é claro: “A soberania popular será exercida pelo sufrágio universal e pelo voto direto e secreto, com valor igual para todos, e, nos termos da lei, mediante: I - plebiscito; II - referendo; III - iniciativa popular.”87

Sufrágio, de acordo com as lições de Borja, “[...] consiste en la intervención direta del Pueblo, o de un amplio sector de él, en la creación de las normas jurídicas, en su aprobación o en la designación de los titulares de los órganos estatales”. ${ }^{8}$

A extensão do sufrágio ao contingente mais abrangente possível de pessoas responde ao esforço de realizar a identidade entre governantes e governados, legitimador do governo democrático. Na lição de Schmitt:

87 Recomendamos a leitura da Dissertação de Mestrado de autoria de Alexandre Sanson, que faz uma análise percuciente desses instrumentos de democracia semidireta. Disponível em: <http://www.dominiopublico.gov.br/download/teste/arqs/cp061534.pdf>. Acesso em: 10 fev. 2012.

88 BORJA, Rodrigo. Derecho político y constitucional. 2. ed. México D.F.: Fondo de Cultura Económica, 1991, p.215. Ou seja: “[...] consiste na intervenção direta do povo ou de um amplo setor dele, na criação das normas jurídicas, em sua aprovação ou na designação dos titulares dos órgãos estatais” (tradução livre). 
[...] la fuerza o autoridade de los que dominan o gobiernan no ha de apoyarse en cualesquiera altas cualidades inaccesibles al pueblo, sino sólo en la voluntad, el mandato y la confianza de los que han de ser dominados o governados, que de esta manera se gobiernan en realidade a sí mismos. ${ }^{89}$

O direito de sufrágio expressa-se pela capacidade de eleger e ser eleito.

Conforme a Constituição Federal, devem votar, obrigatoriamente, os maiores de 18 anos (CF, art.14, $\left.\S 1^{\circ}, \mathrm{I}\right)$ e, facultativamente, os analfabetos, os maiores de 70 anos, e os maiores de 16 e menores de 18 , nos termos do art.14, §1 $1^{\circ}$, II, “a”,"b” e “c”. Os cidadãos que atendam a essas condições têm o direito/dever de votar, o que representa a capacidade eleitoral ativa.

A liberdade de votar está intimamente ligada com a conquista de outras liberdades, como a liberdade de pensamento, de expressão e de associação. Elas se reforçam mutuamente para caracterizar a liberdade ampla da pessoa humana. O eminente professor português Jorge Miranda expõe:

Os direitos de liberdade englobam, na verdade, direitos de diferente conteúdo, de variável estrutura, e passíveis de diversa concretização ou realização. Englobam liberdades, direitos políticos, direitos irredutíveis a liberdades e a direitos políticos, garantias. Nem por isso, todavia, deixa de se justificar a sua aglutinação - por constituírem (ou poderem constituir) um sistema unitário à volta da ideia de liberdade e de limitação de poder (antes de mais, do poder do Estado em abstrato e do poder dos governantes, sejam quais forem, em concreto, o que se aplica, inclusive, aos direitos políticos) e por se traduzirem (ou poderem traduzir) num regime jurídico comum. ${ }^{90}$

A capacidade eleitoral passiva traduz o direito que o cidadão tem de candidatar-se a um cargo eletivo. ${ }^{91}$ A Constituição elenca as condições necessárias para o exercício dessa capacidade de ser eleito, em seu art. $14, \S 3^{\circ}$, exigindo, para tanto, nacionalidade brasileira, pleno exercício dos direitos políticos, alistamento eleitoral,

89 SCHMITT, Carl. Teoría de la Constitución. Trad. Francisco Ayala. Madrid: Alianza, 2006, p. 230: “[...] a força ou a autoridade daqueles que dominam ou governam não deve apoiar-se em qualquer qualidade inacessível ao povo, mas somente na vontade, no mandato e na confiança daqueles que hão de ser dominados ou governados que desta maneira se governam a si mesmos” (tradução livre).

90 MIRANDA, Jorge. Os direitos fundamentais - sua dimensão individual e social. Revista dos Tribunais, São Paulo, ano 1, p. 202, out./dez. de 1992.

91 O portal do TSE indica a lista com os dados atualizados dos 15.264 .775 de eleitores filiados a partidos políticos. A legenda com maior número de filiados é a do PMDB, seguida pelo PT. Disponível em: <http://filiaweb.tse.jus.br/filiaweb/>. Acesso em: 08 dez. 2013. 
domicílio eleitoral na circunscrição, filiação partidária, além de estabelecer a idade mínima para poder almejar a certos cargos.

Somente possui capacidade eleitoral passiva o candidato que estiver em pleno gozo da capacidade eleitoral ativa. Esse é também um pressuposto de elegibilidade.

As hipóteses de inelegibilidade, igualmente previstas na Constituição, têm o propósito de defender a democracia contra possíveis abusos. Lei complementar pode enunciar outras hipóteses, que não as previstas na Carta Magna (CF, art. 14, §9º).

Importante mencionar que as eleições devem ocorrer em um ambiente pacífico, sem traumas ou surpresas, sendo asseguradas as regras do jogo naquele momento, tentando evitar anulação de eleições que atentem contra a disputa em aberto ou que abram espaço para mudança de resultado pelos tribunais. Valiosa é a análise de Lowenstein, ${ }^{92}$ para quem a Constituição se valoriza, na medida em que favorece mudanças na estrutura social sem alteração do processo político.

Faria ressalta a importância da segurança jurídica eleitoral, pois ela garante a máxima efetividade dos direitos de cidadania e a estabilidade e coerência da disputa democrática. A segurança jurídica preservaria,

[d]o ponto de vista substantivo, os direitos de cidadania e a
manutenção do pluralismo ideológico, mediante a adoção de
mecanismos capazes de preservar as liberdades de opinião,
informação e participação. Do ponto de vista procedimental as
garantias para que o jogo democrático seja travado dentro de regras
precisas e estáveis, ainda que despidas de prescrições extensivas e
detalhadas. $^{93}$

Por fim, levanta-se aqui a questão da reeleição, presente na Constituição e merecedora de um ajuste.

\footnotetext{
92 LOWENSTEIN, Karl. Teoria de la constitución. Barcelona: Ariel, 1970, p. 199.

93 FARIA, José Eduardo. Entre a rigidez e a mudança. Revista Brasileira de Direito Constitucional, São Paulo, n. 2, p. 204, jul./dez. 2003.
} 
A equação democrática sempre elencou como um de seus elementos a necessidade da alternância de poder. ${ }^{94}$ Assim, a reeleição é um vício do sistema. Entretanto, esse instituto foi incorporado ao ordenamento pátrio com a Emenda Constitucional $n^{0} 16 / 1997$, que tornou reelegíveis para o cargo, por um único período subsequente, o presidente da República, os governadores de Estado e do Distrito Federal, os prefeitos e quem os houver sucedido ou substituído, no curso do mandato. A reeleição só foi possível em função de interesses e conluios políticos, e é difícil de ser eliminada do sistema brasileiro, já que a força inebriante do poder parece atingir a todos os que o conquistam.

Não bastasse isso, a Constituição Federal dispõe, em seu art. 14, § $9^{\circ}$, que é inelegível para presidente e vice-presidente da República quem não tiver se afastado do cargo que ocupa. Afinal, vicia-se o pleito, quando dele participa quem ainda está exercendo cargo ou emprego na administração pública. Isso afeta a idoneidade do sistema eleitoral, mas se tornou prática corriqueira no país, alardeada em todos os meios de comunicação, sem que haja punição aos seus praticantes. Mesmo a imposição de multas não consegue inibir a prática que, além de imoral, demonstra a falta de respeito por parte dos candidatos para com as leis e instituições do país.

O procedimento eleitoral é um momento único, em que todos os cidadãos são conclamados a decidir o futuro da nação, após um longo debate e avaliação de propostas. É o momento em que o político depende do cidadão. Portanto, deve ser assegurado em todas as Constituições, como elementar ao Estado Democrático de Direito.

\subsubsection{Lei 4.737/65 - Código Eleitoral}

O Código Eleitoral de 1965, instituído durante um regime de exceção, é o quinto diploma eleitoral brasileiro, ${ }^{95}$ com institutos ainda vigor, a despeito de já ter sido modificado por legislação de 1997.

\footnotetext{
94 “[...] não poderíamos deixar de apontar a alternância, ou seja, a efetiva oportunidade de mudança dos personagens no polo do poder, figura, no entanto, indissociável do fairplay [...]”. CAGGIANO, Monica Herman S. Oposição na política. São Paulo: Angelotti, 1995, p. 59.

95 Precedido pelo Decreto $n^{\circ}$ 21.076/32, Lei n ${ }^{\circ}$ 48/35, Decreto-Lei n ${ }^{\circ}$ 7.586/45 e Lei $n^{\circ}$ 1.164/50.
} 
O golpe militar de 31 de março de 1964 interrompeu de forma ilegítima a democracia no Brasil e colocou na presidência o marechal Castelo Branco.

A primeira questão eleitoral relevante do período diz respeito às eleições para governadores de Estado que, naquela época, não se davam todas ao mesmo tempo. Nesse sentido, em 1965, deveriam acontecer eleições para a Guanabara e para outros onze Estados brasileiros, provocando um alerta no meio militar, que receava a vitória de candidatos contrários a seus planos e projetos. Apesar de algumas mudanças ocorridas para evitar essa situação, no Rio de Janeiro e na Guanabara, ganharam candidatos de oposição ao regime. Por conta disso, foi baixado o Ato Institucional $n^{0} 2$, que estipulava eleições indiretas para a Presidência da República.

$\mathrm{O}$ art. $2^{\circ}$ do Código Eleitoral já previa a hipótese de eleição indireta: “Todo poder emana do povo e será exercido, em seu nome, por mandatários escolhidos, direta e secretamente, dentre candidatos indicados por partidos políticos nacionais, ressalvada a eleição indireta, nos casos previstos na Constituição e leis específicas”.

Seu art. $5^{\circ}$, § único, dispunha, ademais, que os militares eram alistáveis, desde que se enquadrassem em alguma das posições ali elencadas.

Durante esse período, todos os partidos políticos foram cassados, e o A.I. 2, embora prevendo a possibilidade de formação de novos partidos, na prática, levou à formação da Aliança Renovadora Nacional (Arena) e ao Movimento Democrático Brasileiro (MDB), o primeiro de situação e o segundo de oposição, mediante a adesão a um ou a outro. Iniciava-se aí um longo período de cassação de parlamentares, que calou muitas vozes do Poder Legislativo. Chacon resume:

Dois partidos surgiram com a dissolução dos treze anteriores: A Aliança Renovadora Nacional (ARENA) e o Movimento Democrático Brasileiro (MDB). A primeira reunindo basicamente udenistas e pessedistas, com adesistas dos mais variados tipos, e o segundo unindo os discordantes do golpe-revolução de 1964, sobretudo petebistas, com alguns pessedistas, raros udenistas e demais. ${ }^{96}$

96 CHACON, Vamireh. História dos partidos brasileiros: discurso e práxis dos seus programas. 2. ed. Brasília: Ed. Universidade de Brasília, 1985, p. 191. 
Em 1966, o Ato Institucional $\mathrm{n}^{0} 3$ ampliou as eleições indiretas para governadores e prefeitos. O Poder Executivo controlava o poder, mantendo-o bem afastado dos cidadãos.

O pior ainda estava por vir. A partir de 1968, a população acuada se mobiliza em protestos contra os militares. O setor estudantil organizou movimentos nas ruas, e greves explodiram pelo país. A gota d’água para os militares foi um discurso do deputado federal Moreira Alves, com fortes críticas ao regime. Por conta disso, ele foi julgado e, surpreendentemente, não foi cassado, provocando a ira dos militares, que instituíram o AI-5, ${ }^{97}$ o instrumento mais violento e repressivo de todo o regime militar. O Congresso foi fechado, afetando diretamente a Justiça e o Direito Eleitorais.

Por fim, “o pacote de abril” de 1977 determinava que um de cada três senadores que o Estado podia eleger seria indicado pelo governo.

Como se vê, esse foi um momento sombrio, que tolheu liberdades e retirou do cidadão a capacidade do votar e escolher representantes. O que há de se dizer é que o Código Eleitoral de 1965, recepcionado com status de legislação complementar pela Carta Magna de 1988, continuou sendo aplicado até que sobreviesse a Lei 9.504/97. Contudo, essa lei não revogou o Código Eleitoral de 1965, acabando por dispor sobre várias questões também estabelecidas neste último diploma.

Curioso notar que, desde a Constituição de 1934, a Justiça Eleitoral sempre teve a competência privativa para o processo das eleições estaduais e municipais. Entretanto, hoje em dia, pode ser feita uma alteração legislativa, por meio de lei complementar, que autorize a transferência da competência executiva acerca das eleições para outro órgão, que não a Justiça Eleitoral. A ela caberia apenas sua função típica jurisdicional. É o que estabelece a Constituição, em seu art. 121: “[...] lei complementar disporá sobre a organização e competência dos tribunais, dos juízes de direito e das juntas eleitorais”.

97 Em obra singular sobre a ditadura brasileira, Gaspari assim discorre sobre o AI-5: "Sem prazo de duração, o AI-5 diferia essencialmente de seus antecessores. No governo Castello os períodos de suspensão das franquias constitucionais tinham prazos. Diante disso a oposição sempre fingia-se de morta durante a ventania, sabendo que ela haveria de passar. Com o AI-5 esse recurso extinguiu-se. Conteve-se a atividade parlamentar oposicionista, e, sobretudo, submeteu-se à máquina do Estado.” GASPARI, Elio. A ditadura escancarada. São Paulo: Companhia das Letras, 2002, p. 232. 


\subsubsection{Lei Complementar $n^{0}$ 64/90 - Lei das inelegibilidades}

Essa lei trouxe hipóteses de inelegibilidades, que significam a ausência da capacidade de ser eleito (capacidade eleitoral passiva). Segundo Medina,

[...] a elegibilidade é o preenchimento das condições inerentes ao cidadão, garantindo-lhe o direito de ser votado, nascendo para o Direito Eleitoral com o registro da sua candidatura, objetivando a concorrer a cargos públicos eleitos. A inelegibilidade ocorre quando o cidadão não preenche as condições legais necessárias, ficando impedido de ser candidato. ${ }^{98}$

Pela Lei Complementar $n^{0}$ 64, art. $1^{0}$, são inelegíveis os inalistáveis. Inalistável é aquele proibido de obter inscrição em lista de eleitores: os menores de dezesseis anos, no momento do voto; o estrangeiro; o conscrito, durante a prestação do serviço militar obrigatório; aquele que não possui domicílio legal na respectiva circunscrição. ${ }^{99}$

Domicílio civil não se confunde com domicílio eleitoral, que leva em conta os vínculos políticos e sociais do interessado, como demarcado pelo TSE, no Ac. 16.397. Dessa maneira, a residência do candidato não fixa de forma determinante seu domicílio eleitoral. Ressalta-se que o interessado a candidatar-se deve ter domicílio eleitoral há pelo menos um ano no local.

Também são inelegíveis, de acordo com esse artigo, os analfabetos, que não sabem ler nem escrever, firmada a jurisprudência: “Alfabetização. Não há ilegalidade em procurar o juiz averiguar se quem pretende registro como candidato atende a esse requisito de elegibilidade, mediante a realização de teste, dispensado se trazida prova suficiente”. 100

Essa norma legal sofreu modificações substantivas depois da aprovação da Lei Complementar $n^{\circ}$ 135/2010, que estabelece, conforme o $\S 9^{\circ}$ do art. 14 da CF, casos de

98 MEDINA, Ademir Ismerim. Comentários à lei eleitoral. 3. ed. São Paulo: Quartier Latin, 2004, p. 34.

99 Práticas como a do senador José Sarney (PMDB-AP) devem, pois, ser coibidas. Político tradicional do Estado do Maranhão, o senador trocou seu domicílio eleitoral para aumentar suas chances de êxito eleitoral, o que contraria a intenção da lei.

100 Ac. N 13.000 de 12.9.96, rel. Min. Eduardo Ribeiro; NO mesmo sentido os acórdãos no 13.277, de 23.9.96, da lavra do mesmo relator, e 13.185, de 23.9.96, rel. Min. Ilmar Galvão. 
inelegibilidade, prazos de cessação e dá outras providências que visam a proteger a probidade administrativa e a moralidade no exercício do mandato. É dever salientar que hoje há novos prazos de afastamento do parlamentar que infringiu dispositivos constitucionais. Enquanto a Lei Complementar $n^{\circ}$ 64/90 fixava o período de inelegibilidade em 3 anos e contado ex tunc, a partir da Lei Complementar $n^{\circ}$ 135/2010, passou a ser de 8 anos, contado ex tunc. ${ }^{101} \mathrm{O}$ prazo da Lei Complementar 64/90 não era suficiente. Se o candidato quisesse concorrer ao mesmo cargo, isso seria possível, posto que as eleições para o mesmo cargo acontecem no país sempre de 4 em 4 anos. Além disso, a inabilitação do candidato, que antes dependia do trânsito em julgado da condenação, agora independe dessa sentença transitada materialmente, bastando decisão colegiada, ainda que contra ela tenha sido interposto recurso.

\subsubsection{Lei 9.096/95 - Lei dos partidos políticos}

Os partidos políticos possuem previsão constitucional e há uma forte tradição brasileira nesse sentido. Em relação à Constituição Federal de 1988, ela alçou os partidos à categoria de pessoa jurídica de direito privado, assegurando-lhes autoorganização e autonomia interna corporis. Por estarem no centro das disputas eleitorais, afirma-se que o Brasil vive uma democracia de partidos, os quais estabelecem as regras e procedimentos para a participação no pleito eleitoral, determinando, ainda, filiação obrigatória do candidato na busca pelo poder político.

Os partidos possuem regras de democracia interna que vinculam as agremiações partidárias ao princípio da legalidade. Nesse sentido, foi instituída uma disciplina legal específica, que busca a plena realização do dispositivo constitucional previsto no art. 17, o qual prevê autonomia partidária, complementada pela Lei 9.259/96. Nesse sentido, o art. $3^{\circ}$ da Lei $n^{\circ} 9.096$ fixa: “É assegurada, ao partido político, autonomia para definir sua estrutura interna, organização e funcionamento”.

A Lei n 9.096/95, combinada com a redação dada pela Lei nº 9.259/96, ambas em concordância com o estabelecido pela CF/88, estipula que os partidos políticos são pessoas jurídicas de direito privado, devendo ter seus atos constitutivos registrados no Cartório de Registro Civil de Pessoas Jurídicas e os estatutos registrados no Tribunal

101 De acordo com a Súmula no 19 do TSE. 
Superior Eleitoral. A Lei $n^{0}$ 9.259/96 afastou a necessidade de registro dos atos constitutivos na Justiça Eleitoral. Dessa forma, os partidos promovem os registros de seus estatutos e comunicam à Justiça Eleitoral as eleições de seus dirigentes e a filiação de seus militantes.

O art. 18 desse instituto legal estabelece: "Para concorrer a cargo eletivo, o eleitor deverá estar filiado ao respectivo partido pelo menos um ano antes da data fixada para as eleições, majoritárias e proporcionais”.

Esse prazo mínimo é considerado inconstitucional por alguns doutrinadores, como Roberto Amaral e Sérgio Sérvulo da Cunha (Manual das Eleições, p. 670), por entenderem que a Carta Magna apenas exige filiação partidária, sem menção a nenhum período mínimo.

É dever enfatizar o art. 26 lei dos partidos políticos, que determina a perda automática da função ou cargo exercidos, na respectiva Casa Legislativa, em função da proporção partidária, para o parlamentar que deixar o partido ao qual era filiado no momento em que foi eleito. De acordo com o legislador, o candidato se identifica com as ideias e princípios estabelecidos no programa e no estatuto partidário, e exerce seu mandato conforme as diretrizes legalmente estabelecidas pelo partido.

A rigor, o candidato depende dos votos da legenda, no modelo de eleição proporcional. De fato, o voto unipessoal dificilmente elege um candidato a deputado, seja ele estadual, seja federal, seja ainda um vereador. Para resolver essa questão, existe o quociente partidário, resultado dos votos dados aos partidos e aos candidatos. É por isso que o mandato não pertence ao candidato, mas ao partido, e o eleito perde seu cargo, na hipótese de infidelidade partidária.

A esse respeito, devem os partidos respeitar os ditames constitucionais e legais, aplicando essa determinação de forma ponderada, pois, do contrário, poderia haver uma verdadeira ditadura partidária. Nesse diapasão, Clève aponta que esse instituto

[...] não pode desviar-se de sua finalidade, que é a manutenção da coesão partidária, para permitir a persecução de objetivos outros que não aqueles legítimos (desvio de finalidade). Nem pode, ademais, transformar o parlamentar em mero autômato, em boca sem vontade, 
destinado apenas a expressar, sem independência e violentando a consciência e a liberdade de convicção, as deliberações tomadas pelos órgãos partidários, nem sempre constituídos por titulares de mandatos conferidos pelo eleitorado. ${ }^{102}$

Em outubro de 2007, o STF decidiu que o parlamentar eleito poderia perder o seu mandato, caso mudasse de legenda partidária. Consulta do $\mathrm{DEM}^{103}$ ao TSE provocou a possibilidade de perda de mandato ao político que trocasse de partido, ficando estabelecido que o mandato não pertencia ao político, mas ao partido ao qual ele é filiado. ${ }^{104}$

Apesar de outras consultas com o mesmo questionamento terem sido propostas anteriormente, como a consulta n. 9.948/89, a posição do TSE e do STF havia sido, por 19 anos (entre 1988 e 2007), a de que, na falta de previsão legal, não há punição para parlamentar que muda de partido após uma eleição.

Essa situação mudou com a Consulta $n^{0}$ 1.398/07, que perguntava: “[...] os partidos e coligações têm o direito de preservar a vaga obtida pelo sistema eleitoral proporcional quando houve pedido de cancelamento de filiação ou de transferência do candidato eleitos por um partido para outra legenda?” E, dessa vez, a decisão do TSE foi no sentido de que, se havia obrigatoriedade constitucional de o candidato de ser vinculado a um partido político, os partidos têm o direito de preservar os mandatos de parlamentares que deixam o partido. A estratégia usada nessa nova consulta foi a de não fazer referência à perda do mandato, mas apenas definir a titularidade desse mandato, se ele era do partido ou do candidato. Com um voto em desacordo, proferido pelo Min. Marcelo Ribeiro, ficou definido que era do partido.

Os partidos, amparados nessa resposta, dirigiram-se à mesa diretora da Câmara dos Deputados para ocupar as vagas dos deputados que haviam migrado de partido.

\footnotetext{
102 CLÈVE, Clèmerson Merlin. Fidelidade partidária - estudo de caso. Curitiba: Juruá, 1998, p. 26.

103 O PFL alterou sua denominação para Democratas (DEM), em março de 2007. A simbiose é profunda. Aqui, adotamos apenas DEM.

104 A punição com a perda de mandato a parlamentar que deixasse o partido pelo qual foi eleito foi prevista pela primeira vez, no país, pela EC $n^{0}$ 1/1969, instituída durante o governo militar, modificando a redação do art. 152 da Carta de 1967.
} 
Como a mesa indeferiu o requerimento, os partidos ingressaram com mandados de segurança $^{105}$ junto ao STF, que confirmou a tese do TSE.

Todavia, houve uma divergência quanto ao marco temporal, que foi resolvida com modulação da decisão do STF, prevista pela Lei $n^{0} 9.868 / 99$, § 27, que permite ao Supremo o controle sobre os efeitos práticos de suas decisões, possuindo autorização legal para restringir a lei no tempo e espaço. No caso da fidelidade partidária, o marco temporal definido foi a partir da decisão do TSE na resposta à consulta $n^{0}$ 1.398/07. Somente as migrações realizadas após essa data seriam passíveis de reivindicação pelos partidos.

É fácil entender que a excessiva mudança de partidos deforma a representação popular e que a mudança de legenda ofende a soberania popular. Porém, quando a Constituição estabelece exceções a hipóteses ou direitos, ou essas exceções estão expressas no texto constitucional, ou é dada uma autorização expressa para que uma lei o faça. Isso provoca um comprometimento do Legislativo, no sentido de lhe exigir atuação para garantir efetividade das normas. E, se o Legislativo se mantém inerte, deve ser acionado por outros mecanismos, para que, assim, seja garantido o equilíbrio e a harmonia dos poderes.

A jurisprudência do STF havia sido dominante, sempre entendendo que a troca de partido não é causa de perda de mandato. Esse novo entendimento, sem uma previsão legal, e oriundo de uma consulta feita ao TSE, é um resultado do ativismo judicial, uma prática preocupante, que se tem tornado corriqueira e que desrespeita o princípio da separação de poderes.

\subsubsection{Lei 9.504/ 97- Lei das Eleições}

Essa lei possui grande importância para o ordenamento jurídico brasileiro. A cada ano, era editada uma nova lei para tratar das eleições, situação que perdurou até 1997, com a edição da lei eleitoral, uma norma perene a regular todas as eleições posteriores.

105 MS No 26.602/07, impetrado pelo PPS; MS No 26.603/07 pelo PSDB; MS No 26.604/07, impetrado pelo DEM. 
Em seu art. $1^{\circ}$, ela estabelece o início das eleições, que se realizam sempre no primeiro domingo de outubro do ano eleitoral, sendo eleito o candidato que alcançar maioria absoluta de votos, não computados os em branco e os nulos (art. $2^{\circ}$ ). Explicita Medina:

São nulos os votos atribuídos a candidatos não registrados ou àqueles que tiverem sua inelegibilidade declarada antes da data da eleição. Serão também nulos os votos atribuídos a um partido político que não obteve o seu registro deferido pelo Tribunal Superior Eleitoral. ${ }^{106}$

Isso deriva do sistema de representação brasileiro, que é proporcional ao número de votos válidos obtidos por cada uma das legendas políticas. Esse artigo, ademais, deve ser interpretado junto com o art. 109, $\S 2^{\circ}$, do Código Eleitoral, valendo a determinação de que o partido ou a coligação que não obtiverem número de votos igual ao quociente eleitoral ${ }^{107}$ não terão eleito candidatos à Câmara dos Deputados, nem às Assembleias Legislativas, nem à Câmara Legislativa do Distrito Federal ou Câmara de Vereadores.

O art. $6^{\circ}$ da Lei Eleitoral trata da formação de coligações, possibilidade dada aos partidos políticos, desde que dentro da mesma circunscrição.

Questão polêmica e amplamente debatida surgiu, por exemplo, no caso da verticalização das coligações partidárias, originária da Resolução TSE n 21.002/2002, dada como resposta à Consulta TSE nº 715/2001, formulada pelo PDT. Essa resolução estabelecia que os partidos políticos que fizessem coligação para eleição da Presidência da República não poderiam formar coligação com outros partidos políticos para eleição de governador de Estado ou do Distrito Federal, senador, deputado federal, estadual ou distrital. Entendeu o TSE que deveria haver simetria entre as coligações nacionais e regionais, decisão que modifica o exercício do direito em relação às coligações eleitorais. O direito dos partidos políticos de realizar coligações assimétricas nos três âmbitos do Estado foi limitado, mesmo sem ter havido uma previsão legislativa. Afinal, o art. $6^{\circ}$ da Lei $n^{\circ} 9504 / 97$ fixa que

\footnotetext{
106 MEDINA, Ademir Ismerin. Op. cit., p. 21.

107 Cálculo utilizado para distribuição de cadeiras no sistema de votação proporcional, definido no Código Eleitoral Brasileiro e estudado no capítulo 2 desta tese.
} 
[é] facultado aos partidos políticos, dentro da mesma circunscrição, celebrar coligações para eleição majoritária, proporcional, ou para ambas, podendo, neste último caso, formar-se mais de uma coligação para a eleição proporcional dentre os partidos que integram a coligação do pleito majoritário.

Não se pode inferir que esse artigo apresenta algum tipo aberto, por isso, inovou o TSE a ordem legal, sem poder fazê-lo.

Foram propostas duas ADIs - ADI $n^{0}$ 2.628-3, proposta pela PFL, e ADI $n^{0}$ 2.626-7, do PCdoB, PL, PT, PSB e PPS - perante o STF, que decidiu não conhecer dessas ações, alegando impossibilidade de controle de constitucionalidade de ato normativo secundário.

Se o STF decidiu não atacar o mérito, o TSE o fez, sendo que as questões se basearam em temas como autonomia partidária, separação de poderes, princípio eleitoral da anualidade, ou seja, todas essas noções de estatura constitucional. ${ }^{108} \mathrm{~A}$ verticalização saiu vitoriosa com base no art. 17, I, da CF/88, que, no fundo, não constitui um princípio constitucional.

O STF, ao não acolher as ADIs, entendeu que não havia violação aos direitos constitucionais, mas uma mera interpretação de um artigo de lei. Com isso, regras importantes do processo eleitoral foram aprovadas e aplicadas no mesmo ano em que tiveram vigência, uma ofensa grave ao princípio da anualidade (art. 16 da CF/88).

O Congresso Nacional, insatisfeito com essa situação, resolveu agir e promulgou a EC $n^{0} 52 / 2006$, que alterou o $\S 1^{\circ}$ do art. 17 da CF/88 e eliminou a exigência da simetria entre as coligações eleitorais, de forma definitiva.

Esse caso é mais um exemplo de ativismo judicial, que autorizou uma atuação normativa do TSE, invadindo a autonomia partidária, o princípio da anualidade e as próprias escolhas do Poder Legislativo.

108 Assim, o Min. Sepúlveda Pertence afirmou que o art. $6^{\circ}$ da Lei $n^{\circ}$ 9.504/97 previa liberdade para que os partidos estabelecessem suas coligações, em função de sua autonomia. O min. Ilmar Galvão aduziu que disciplina sobre processo eleitoral trata de matéria de competência exclusiva do Congresso, de acordo com o art. 22, I da CF/88, ocorrendo usurpação da competência legislativa. E o Min. Marco Aurélio tratou da indiscutível inovação trazida ao processo eleitoral, em confronto com previsão constitucional. Isso apenas para citar alguns argumentos pertinentes e com base constitucional. 
Cabe destacar, ainda, o art. 23 e 24 da Lei $n^{\circ}$ 9.504/97, que abordam as doações.

A Constituição Federal estabelece que o povo é a fonte primária do poder estatal, podendo também exercer o poder por meio de representantes eleitos pelo voto direto. Dessa forma, é necessário haver um governo democrático e representativo que preserve a autonomia dos partidos e a igualdade de oportunidades de seus candidatos.

Os partidos precisam, por óbvio, de recursos financeiros para sua manutenção e para a realização de suas campanhas, e podem receber doações de pessoas físicas, sendo proibido aos partidos, nos termos da Constituição, art. 17, II, receber recursos de entidade ou governo estrangeiro.

O art. 23 da Lei $n^{\circ}$ 9.504/97 é regulamentado pelo art. 81 do mesmo diploma legal, que impõe limites às contribuições de pessoas físicas, ${ }^{109}$ tentando manter a igualdade de oportunidades no pleito e lisura eleitoral.

Doações de pessoas jurídicas são ainda autorizadas, bem como o uso de recursos próprios dos partidos políticos, que podem se valer da comercialização de bens e serviços e usar o valor auferido nas campanhas políticas.

Caso as normas de arrecadação sejam descumpridas, não haverá recebimento das quotas do Fundo Partidário (art. 25, da Lei nº 9.504/97), o que, para Cândido, é um dispositivo que “[...] comporta duas sanções. Uma, partidária, com a perda do direito ao recebimento da quota do Fundo Partidário. [...] A outra sanção é pessoal, destinando-se aos candidatos." 110

109 Em se tratando de menor, pode doar bens excluídos do usufruto e administração de seus pais, como, por exemplo, aqueles recebidos no exercício de uma atividade profissional (art. 1.693, inc. II, do Código Civil).

110 CÂNDIDO, Joel J. Direito Eleitoral Brasileiro. 11. ed. São Paulo: EDIPRO, 2004, p. 424. 
Essas sanções protegem o art. 14, § 9 ${ }^{\circ}$, da CF, garantindo eleições que fluem de forma normal e legítima, sem interferência do poder econômico, ${ }^{111}$ além de afastar abuso de exercício de função.

O mais importante é que haja transparência nessas doações. Sua falta fulmina a legitimidade das eleições no país.

\subsubsection{Lei 12.034/09 - Minirreforma política e eleitoral}

A Lei $n^{0} 12.034 / 2009$ representa um passo fundamental para a adequação da propaganda política, no Brasil, com as inovações trazidas na última década do século XX. Regras claras sobre o uso da Internet nas campanhas políticas foram estabelecidas. As propostas foram amplamente - e rapidamente ${ }^{112}$ - debatidas e houve intensa participação dos parlamentares de todos os partidos, recuperando, de certa forma, a imagem do Poder Legislativo, que atuou de maneira enérgica para conseguir analisar as sugestões enviadas por todos os partidos.

A autoria do projeto é do deputado Henrique Eduardo Alves (PMDB-RN), coordenado pelo deputado Flávio Dino (PCdoB/MA). Ao ir para o Senado, o projeto recebeu 67 emendas; todavia, ao voltar para a Câmara, 64 delas foram rejeitas, tendo sido mantidas apenas as três que se referiam às regras para a Internet.

A primeira delas foi a redação do art. 57-D da Lei $n^{0}$ 9.504/97, que privilegiou a manifestação de pensamento pela Internet, vedando o anonimato e garantido o direito de resposta. Esse artigo deixa claro que censura na rede virtual não é aceita.

111 Para Ribeiro, “[...] por abuso de poder econômico, para efeitos da lei eleitoral, pode-se entenderas infrações às normas de arrecadação e aplicação de recursos em campanha eleitoral, que configurem o uso ilegal de dinheiro, bens e serviços, para auxiliar determinado ou determinados candidatos, tentando influenciar ou influenciando na normalidade e legitimidade das eleições. RIBEIRO, Renato Ventura. Lei eleitoral comentada. São Paulo: Quartier Latin, 2006, p. 194.

112 O projeto de lei que deu origem à lei ordinária em questão foi o de $n^{0} 5.498 / 2009$, tendo sido apresentado em tempo recorde, apenas 8 dias. A tramitação na Câmara dos Deputados foi também muito ágil, no intuito de aprovar o projeto com pelo menos "um ano e um dia" de antecedência às eleições de 2010, respeitando a exigência do art. 16 da CF. A tramitação do projeto de lei está disponível em: $<$ http://www.camara.gov.br/proposicoesWeb/fichadetramitacao?idProposicao=440269>. Acesso em: 06 abr. 2012. 
$\mathrm{O}$ art. $7^{\circ}$ da Lei $\mathrm{n}^{0}$ 12.037/2009 dá permissão ao uso da Internet até mesmo no dia da eleição, não se aplicando a restrição prevista no parágrafo único do art. 240 do Código Eleitoral que trata de propaganda em geral.

E a redação do art. 57-F da Lei $n^{\circ}$ 9.504/97, dada pela Lei $n^{0} 12.034 / 2009$, eliminou o prazo de 24 horas que era antes estabelecido para que o provedor de Internet retirasse do ar propaganda considerada irregular pela Justiça Eleitoral. O prazo passa a ser fixado pela própria Justiça Eleitoral, de acordo com a análise do caso concreto.

Como essas alterações se referem à propaganda eleitoral na Internet, elas serão analisadas de forma mais detalhada em item próprio, no Capítulo 3.

Além disso, outras mudanças na lei partidária merecem menção.

O art. 41-A, §1º , passou a definir: "Para a caracterização da conduta ilícita, é desnecessário o pedido explícito de votos, bastando a evidência do dolo, consistente no especial fim de agir”. Com isso, o pedido de voto, ainda que implícito, caracteriza uma conduta ilícita, de forma que foi consagrada a "participação indireta do candidato". Todavia, para a tipificação dessa conduta, é imprescindível que o candidato seja o autor da ação, ou que tenha dela participado ou anuído. A alteração trazida pela Lei $\mathrm{n}^{\circ}$ 13.034/2009 à Lei no 9.504/97 tem respaldo no entendimento assentado no TSE, como aduz o Min. Sálvio de Figueiredo, em seu voto no Acórdão nº 19.566:

Não fosse isso, em face da costumeira criatividade dos candidatos e de seus colaboradores, correr-se-ia o risco de tornar inócua a citada norma, mantendo impunes e até mesmo estimulando os candidatos na prática de abusos e ilícitos que a sociedade, notadamente a mais próxima dos fatos, repudia com justificada veemência.

Se, por um lado, a negociação do voto para determinado candidato pode ser feita diretamente ou por interposta pessoa, por outro lado, ela tem que ser, necessariamente, dirigida a um eleitor, individualmente identificado. Uma promessa de campanha ou uma propaganda institucional do governo, como a propaganda do Programa Bolsa-Família, por exemplo, caracterizam-se como propostas impessoais e genéricas. 
Visando a ampliar a participação política das mulheres, essa lei garantiu reserva de recursos do Fundo Partidário e do tempo de propaganda na TV às mulheres.

O número de mulheres no Brasil equivale a 51\% da população. Apesar de representarem 51\% da população, sua participação no Poder Legislativo ainda padece de uma sub-representação que, no espírito da mudança trazida pelo art. 44, V, merece ser revista. Assim, programas que incentivem e proporcionem maior participação feminina nessa seara devem ser criados, e os partidos devem reservar $5 \%$ das verbas do fundo para tanto. Caso isso não aconteça, o $\S 5^{\circ}$ do inciso $V$ desse artigo 44 impõe uma sanção ao partido, que deverá, no ano seguinte, “[...] acrescentar o percentual de 2,5\% do Fundo Partidário para essa destinação, ficando impedido de utilizá-lo para finalidade diversa.”

A minirreforma eleitoral, entretanto, trouxe algumas situações preocupantes, como a aprovação das doações ocultas e das doações pela Internet, neste último caso, seguindo o sucesso do modelo das eleições presidenciais norte-americanas que levaram à eleição de Barack Obama.

Nesse sentido, pessoas físicas, e somente elas, podem fazer doações pela Internet para o seu candidato. Elas devem ser feitas mediante formulário eletrônico, nos limites legais que correspondem a $10 \%$ do rendimento bruto da pessoa física, no ano anterior às eleições, dispensando a assinatura do doador (art. 23, § $2^{\circ}$ da Lei $n^{\circ}$ 9.504/97). E o partido apenas indicará os doadores da Internet 30 dias após a eleição, no final da prestação das contas. Esse procedimento facilita a fraude e dificulta a investigação, de sorte que deveria ter sido coibido.

Ademais, a antiga lei eleitoral fixava o prazo inicial que possibilitava a doação por pessoa física, autorizado a partir do registro dos Comitês Financeiros. A nova lei não colocou esse marco explicitamente, mas ele deve ser mantido, em função do princípio da moralidade, previsto constitucionalmente. 
O artigo 23, III, inovou também, ao permitir que essa doação pela Internet seja feita por cartão de crédito, ${ }^{113}$ sendo, nesse caso, obrigatória a identificação do doador, cuja responsabilidade é do partido político, e a emissão de recibo eleitoral.

A lei fez a questionável previsão das doações ocultas (art. 23, § $2^{\circ}$, da Lei $\mathrm{n}^{\circ}$ 9.504/97, c.c. art. 39, $\S 5^{\circ}$, da Lei $\left.n^{\circ} 9.096 / / 97\right)$, que autoriza aos doadores colocar dinheiro no partido, e não diretamente no candidato, podendo essa doação ser realizada antes ou durante o período eleitoral. Agrava essa previsão legal o fato de a Lei Partidária não obrigar o partido a comprovar a origem dos recursos usados para saldar dívidas de campanha dos candidatos, na prestação de contas anual subsequente (art. 32). Tudo isso amplia as chances de fraude nas contas da campanha eleitoral de candidatos.

Por fim, convém lembrar que a minirreforma política introduziu uma mudança polêmica na Lei $n^{\circ}$ 4.737/65: o voto em trânsito para eleitores em território nacional que queiram exercer seu direito de voto nas eleições para Presidente e Vice-Presidente (art. 223-A, acrescentado ao Código Eleitoral).

A intenção da lei era assegurar a universalidade do voto, contudo, ela não previu a forma como esse voto seria viabilizado. Ora, para que o TSE permita que o eleitor brasileiro vote mesmo estando fora de seu domicílio eleitoral, é necessário um cadastro prévio desse eleitor, para que o nome dele conste do programa da urna eletrônica do local onde ele vai votar. O eleitor, portanto, tem que se programar para fazer esse cadastramento e saber onde estará nesse período. A urna eletrônica não pode ser colocada em rede, pois haveria a possibilidade de ela ser invadida por hackers ou crackers, ${ }^{114}$ interferindo na segurança do processo eleitoral. Não é simples!

O TSE editou a Resolução 23.215/2010, inovando a Lei $n^{0} 12.034 / 2009$, ao criar as condições para esse voto. Como a Lei n 9.504/97 proíbe o TSE de restringir direitos por resolução, esta medida não poderia ter criado regras limitadoras, mas o fez.

113 A Resolução no 23.216/2010 proíbe o uso de cartão de crédito emitido no exterior, corporativo ou empresarial, para esse fim.

114 “Há um certo sensacionalismo no uso da palavra 'hacker'. Seu sentido original refere-se a 'gênios' da computação. Figuras como Steve Jobs ou Bill Gates começaram como 'hackers'. Existe até um código de 'ética hacker' (bit.ly/9DmAgw). Quem não segue é chamado de 'cracker', que é a palavra para quem usa o conhecimento da rede para causar danos.” LEMOS, Ronaldo. Reação ao WikiLeaks põe Internet em risco. Disponível em: <http://www1.folha.uol.com.br/fsp/folhatee/fm2012201006.htm>. Acesso em: 20 dez. 2010. 
Assim, para que o eleitor possa votar fora de seu domicílio eleitoral, ele terá que se habilitar em um cartório eleitoral do Brasil, entre 15 de julho e 15 de agosto do ano em que ocorra eleição para Presidente ou Vice-Presidente; com isso, ele não poderá votar na sua seção de origem; se não estiver na capital de sua indicação, terá que justificar o voto, mesmo se estiver no seu próprio domicílio eleitoral.

O fundamento desse artigo foi a equiparação com o brasileiro que está em situação análoga no exterior. Como existe previsão legal para essa situação, abriu-se uma nova oportunidade de voto para o eleitor no Brasil. Todavia, a lei só dá essa autorização para o eleitor da capital, enquanto o eleitor no interior fica sem essa proteção, o que leva a uma inconstitucionalidade da lei.

Essa questão, com sorte, terá um final mais simples, quando se completar em todo o país o sistema de identificação especial eleitoral (biometria), ${ }^{115}$ que integrará a Justiça Eleitoral, o INSS e o Instituto de Identificação. Com a biometria plenamente realizada, qualquer eleitor poderá votar em qualquer lugar do território nacional.

\subsubsection{LC 135/10 - Lei da Ficha Limpa}

A Lei da Ficha Limpa transformou-se em tema recorrente no país, desde 2008, por ter conseguido reunir o significante número de cidadãos necessário para a aprovação do projeto de lei e pelo impacto causado no cenário eleitoral brasileiro.

O Movimento de Combate à Corrupção Eleitoral (MCCE), organização nãogovernamental voltada para o combate da corrupção eleitoral no Brasil, foi o responsável pela criação do projeto da Ficha Limpa e um dos principais organizadores dessa campanha.

Seus esforços foram bem-sucedidos. Conseguiram reunir 1,3 milhão de assinaturas para aprovar um projeto de lei de iniciativa popular cujo objetivo era exercer maior controle sobre a idoneidade dos candidatos.

\footnotetext{
115 O site do TSE disponibiliza o estágio em que esse cadastramento se encontra. Disponível em:
} <http://www.tse.jus.br/eleicoes/biometria-e-urna-eletronica/biometria-1>. Acesso em: 08 dez. 2013. 
Com isso, o projeto de iniciativa popular (PLP $n^{0}$ 518/2009) resultou na Lei Complementar $n^{0}$ 135/10 (Ficha Limpa), alterando a Lei Complementar $n^{\circ}$ 64/90 (Lei das Condições de Inelegibilidade), o que representou não apenas uma vitória pela moralidade eleitoral, mas também uma grande conquista da democracia, porquanto o instituto da iniciativa popular, que torna possível à população apresentar projetos de lei, é pouco utilizado no Brasil. ${ }^{116}$

O projeto de lei colheu as assinaturas por meio de um abaixo-assinado divulgado em todos os Estados da Federação e no Distrito Federal. Em 05 de maio de 2010, foi aprovado pela Câmara Federal, seguido da aprovação do Senado, em 19 de maio do mesmo ano, convertendo-se na Lei Complementar acima mencionada. ${ }^{117}$

O texto constitucional prevê, em seu art. $61, \S 2^{\circ}$, o instituto da iniciativa popular no ordenamento brasileiro e estabelece que ele poderá ser exercido “[...] pela apresentação à Câmara dos Deputados de projeto de lei subscrito por, no mínimo, um por cento do eleitorado nacional, distribuído pelo menos por cinco Estados, com não menos de três décimos por cento dos eleitores de cada um deles”.

A fundamentação do projeto se baseou no art. 14, § 9º da Constituição Federal. Esse dispositivo afirma que a soberania popular será exercida pelo sufrágio universal e pelo voto direto e secreto, mediante plebiscito, referendo ou iniciativa popular, possibilitando que Lei Complementar estabeleça casos de inelegibilidade que visem à lisura do pleito eleitoral, garantindo a probidade das eleições e impedindo o abuso da máquina administrativa e do poder econômico.

A proposta original do PLP n ${ }^{0}$ 518/2009 previa, como condição suficiente para impedir que o candidato concorresse a um cargo nas eleições, a condenação em primeira instância ou, conforme o crime, a denúncia recebida por órgão colegiado. O texto foi

116 Em cenário brasileiro, apenas quatro leis tiveram origem em projetos que partiram da iniciativa popular: Lei $n^{\circ}$ 8.930/94 (Lei dos crimes hediondos), Lei no 9.840/99 (contra a corrupção eleitoral), Lei $\mathrm{n}^{\circ}$ 11.124/05 (que trata do Sistema Nacional de Habitação de Interesse Social) e a Lei Complementar sob análise.

117 Ver o trâmite no site da Câmara dos Deputados. Disponível em: $<$ http://www.camara.gov.br/proposicoesWeb/fichadetramitacao?idProposicao=452953>. Acesso em: 10 out. 2010. 
alterado, prevalecendo a modificação do Substitutivo feito pelo deputado José Eduardo Cardozo (PT/SP), o qual exigiu condenação por órgão colegiado. ${ }^{118}$

Debate surgiu em relação à aplicação dessa Lei Complementar para as eleições de 2010. ${ }^{119}$ A tese de aplicabilidade foi corretamente afastada pelo Tribunal Superior Eleitoral, que levou em conta os princípios da anuidade eleitoral, da irretroatividade das leis e da segurança jurídica para sustentar sua decisão de que a Lei da Ficha Limpa passaria a valer somente a partir das eleições municipais de 2012, o que foi ratificado pelo Supremo Tribunal Federal.

Além dessa polêmica, o professor Fernando Almeida discorre sobre a polêmica em torno da constitucionalidade da lei.

Explica ele que a Lei Complementar $n^{\circ}$ 64/90 tinha como critérios de inelegibilidade: nacionalidade, alfabetização, idade, elementos circunstanciais ligados ao exercício de outros cargos, e outros elementos ligados à condenação pela prática de atos ilícitos. Entretanto, a modificação trazida pela Lei Complementar ${ }^{0}$ 135/10, “[...] além de ampliar substancialmente o rol de ilícitos a ensejarem inelegibilidade, passou a considerar suficiente, como indicativo de mácula na vida pregressa do candidato, decisões ainda não definitivas.”120

Relembrando as lições de Kelsen, Almeida alerta que, para que o ato seja contrário à ordem jurídica, há de ter havido decisão proferida de forma definitiva pelo órgão competente, com a análise de seu "sentido objetivo”. Com isso, a Lei Ficha Limpa opta por

[...] reforçar a decisão ainda subjetiva da autoridade judicial, em detrimento da decisão também subjetiva do eleitor.

\footnotetext{
118 Sem dúvida, prevaleceu a melhor técnica jurídica, posto que, de uma condenação em segundo grau, cabe recurso ao STJ, ao STF ou, se for matéria eleitoral, ao TSE. Neste caso, o recurso, além de não ter efeito suspensivo, tampouco discute matéria fática, apenas de direito.

119 Citamos aqui os leading cases decididos no STF e que se referem às renúncias de Joaquim Roriz e de Jader Barbalho de seus mandatos de senadores, para escaparem de processo de quebra de decoro parlamentar: RE 630147/DF e RE 631102/PA.

120 ALMEIDA, Fernando Dias Menezes. Estatuto do candidato: reflexões sobre a "Lei Ficha Limpa”. In: CAGGIANO, Monica Herman S. (Coord.); MESSA, Ana Flávia; ALMEIDA, Fernando D. M. de (Org.). Direito eleitoral em debate: estudos em homenagem a Cláudio Lembo. São Paulo: Saraiva, 2013, p. 71.
} 
Trata-se de uma opção, aliás, inserida numa tendência contemporânea de, conscientemente ou não, privilegiar o técnico-jurídico e rebaixarse o político. ${ }^{121}$

Ora, essa interpretação firme do texto legal é acertada. Afinal, sem o trânsito em julgado da decisão, os atos ficam adstritos à vontade subjetiva do julgador de primeira instância que, por vezes, pode ser modificada.

Em face dessa Lei Complementar $n^{0}$ 135/2010, foram ajuizadas as Ações Diretas de Constitucionalidade $n^{0} 29$ e $n^{0} 30$ do Distrito Federal e a Ação Direta de Inconstitucionalidade ${ }^{\circ}$ 4.578/Distrito Federal. Apesar de argumentos contrários, como os do Min. Gilmar Mendes ${ }^{122}$, a Lei Complementar $n^{0} 135 / 2010$ foi considerada constitucional. Convém ressaltar os votos do Min. Luiz Fux, que afirmou que a própria legitimidade da Constituição depende, em certo grau, da sua responsividade à opinião pública popular, e do Min. Joaquim Barbosa:

Não se pode negar que um projeto de lei de iniciativa popular que trata especificamente de um tema diretamente ligado à escolha dos nossos representantes revela muito mais do que uma simples mobilização social. Revela, sobretudo, um despertar de consciência a respeito do real significado da democracia e de um dos seus elementos constitutivos essenciais que é a representação política.

O Supremo Tribunal Federal entendeu pela constitucionalidade da lei em foco, por sete votos a quatro, e o argumento que prevaleceu foi o de que a impossibilidade da candidatura não era pena, mas pré-requisito. Com isso, os atingidos pela Lei Complementar $\mathrm{n}^{0} 135$ ficam impedidos de disputar eleições por pelo menos oito anos.

O referido documento legal alterou a Lei Complementar $n^{\circ}$ 64/1990, prevendo a possibilidade de inelegibilidade independentemente do trânsito em julgado da decisão condenatória, bastando a decisão proferida por órgão colegial competente e o argumento de ofensa a valores intangíveis, o que afronta os princípios da presunção de inocência. A leitura do STF foi a de que esse princípio é regra de maior força no campo penal e que

121 ALMEIDA, Fernando Dias Menezes de. Op. cit., p. 73.

122 Para Gilmar Mendes a aprovação da lei complementar estava sendo influenciada pela opinião pública momentânea que pedia a moralização da política. Todavia, não se pode relativizar direitos fundamentais em função do clamor público, por isso sua manifestação contrária. Afirmou, ademais, que a morosidade da justiça deve ser enfrentada. Assim, ao invés da suspensão dos direitos políticos sem trânsito em julgado de sentença, dever-se-ia investir em uma justiça mais célere, evitando decisões injustas. 
só possui caráter de pena, no campo eleitoral, nas hipóteses de perda ou suspensão dos direitos políticos, de acordo com o art. 15, III, da CF/88. Houve uma fragilização do princípio da presunção de inocência em relação à proteção do interesse público de se ver protegidos contra candidatos moralmente desqualificados. Ora, para isso, o cidadão tem o voto, ou seja, se o representante é inapto ou ímprobo, basta não receber o voto popular.

É fácil perceber que houve um grande clamor popular pelo tema, com a coleta de mais de um milhão de assinaturas de cidadãos envolvidos no debate, denotando o prazer de uma participação ativa imbuído de um ideal republicano, o que é fundamental no processo eleitoral de um país democrático. Todavia, com base nos apontamentos de Almeida, ressalta-se que algumas decisões jurisdicionais vão na contramão de princípios claros estabelecidos na Carta Magna e que são igualmente importantíssimos para a condução segura do pleito eleitoral, devendo ser privilegiados nas decisões dos tribunais.

\subsection{Histórico e relevância da Justiça Eleitoral no Brasil}

A Justiça Eleitoral brasileira é uma Justiça de vanguarda, um modelo de bom funcionamento dentro do Poder Judiciário, observado em muitos países por diversos operadores do Direito.

Eleição no Brasil é uma prática corriqueira, que começou bem antes da Independência. No período colonial, já havia eleições indiretas para a escolha dos membros das Câmaras Municipais. Sem dúvida, o brasileiro está habituado a votar e gosta de votar.

A estrutura dos órgãos do Poder Judiciário brasileiro previu uma Justiça Eleitoral, que possui seara de atuação específica e standards que lhe são peculiares. Seus procedimentos atendem às questões que surgem nas eleições e que precisam ser prontamente definidas, ${ }^{123}$ possuindo capacidade interpretativa mediante resoluções.

123 O processo eleitoral é célere e as questões devem ser prontamente respondidas, pois um fato inverídico divulgado em um período eleitoral pode atingir diretamente o voto do eleitor e provocar danos irreversíveis. Por isso, se a parte interessada não se manifesta no momento apropriado, não 
Seu instrumental visa a garantir seriedade e lisura ao processo eleitoral. A autonomia do órgão regulador frente aos interesses político-partidários é fundamental, nesse sentido, ${ }^{124}$ e é isso o que se observa, quando da análise desse órgão, o qual apresenta uma atuação independente dos órgãos majoritários e um modelo de governança eleitoral neutro, em relação aos interesses políticos.

A Justiça Eleitoral foi criada, como apontado anteriormente, em 1932, fruto dos ideais almejados pela Revolução de 30, que se rebelou contra as negociações políticoeleitorais dos grupos dominantes e ergueu a bandeira da moralização das eleições, propondo um processo eleitoral mais transparente, conduzido por uma justiça realmente imparcial e exclusivamente responsável pelo tema. Com a sua instauração, os poderes executivo e legislativo perderam o controle do processo eleitoral e as câmaras legislativas deixaram de conduzir a verificação dos mandatos.

A competência da Justiça Eleitoral inclui a fase de diplomação dos candidatos, estendendo-se até o exame das ações propostas durante a fase do processo de propaganda política eleitoral, além da votação, incluindo as ações de impugnação ao mandato eletivo e ao recurso contra diplomação. O ato de posse já não é competência da Justiça Eleitoral.

A Constituição Federal, em seu artigo 118, determina: “São órgãos da Justiça Eleitoral: I - O Tribunal Superior Eleitoral; II - os Tribunais Regionais Eleitorais; III os Juízes Eleitorais; IV - as Juntas Eleitorais.”

O Tribunal Superior Eleitoral (TSE) foi criado em 24 de fevereiro de 1932. Atualmente, é composto de, no mínimo sete membros, sendo que a CF, em seu art. 96, II, autoriza seu incremento. São três ministros eleitos dentre os membros do STF, dois ministros eleitos entre os membros do STJ e dois Ministros nomeados pelo presidente da República, escolhidos dentre 6 advogados de notável saber jurídico e ilibada reputação, indicados pelo STF (art. 119 da CF). Para cada ministro efetivo, é eleito um substituto,

poderá reclamar posteriormente (CE, ART. 171). Também não se admite a recontagem de votos, se não tiver ocorrido recurso após a apuração de cada urna (CE, art. 181). A preclusão é fatal, nesse ramo do Direito.

124 SADEK, Maria Tereza. A justiça eleitoral e a consolidação da democracia no Brasil. São Paulo: Konrad Adenauer, 1995. 
escolhido pelo mesmo processo. O Tribunal elege seu presidente e vice-presidente, dentre os ministros do STF, e o corregedor geral, dentre os ministros do STJ.

Órgão máximo da Justiça Eleitoral, o TSE tem suas principais competências fixadas pela Constituição Federal e pelo Código Eleitoral (Lei $n^{0} 4.737 / 1965$ ), e a ele cabe o exame das questões eleitorais em última instância. Exerce papel fundamental na construção da democracia brasileira e no fortalecimento da cidadania, atuando conjuntamente com os tribunais regionais eleitorais (TREs), que são os responsáveis diretos pela administração do processo eleitoral. Possui grande relevância na interpretação das normas eleitorais, editando resoluções para o entendimento da legislação eleitoral. Salienta-se que, nesse caso, sua função é apenas sintetizar as normas legais, colocando-as em linguagem mais objetiva, clara e direta, sem ter o direito de inovar a ordem jurídica, ${ }^{125}$ pois somente a União pode legislar sobre Direito Eleitoral (CF, art. 22, I).

As decisões do TSE são irrecorríveis, com exceção daquelas contrárias à Constituição Federal, para as quais cabe recurso extraordinário, além das decisões denegatórias de habeas corpus ou mandado de segurança (art. 121, § $3^{\circ}$, CF). Possui jurisdição penal, abrangendo todos os crimes eleitorais e os que lhe forem conexos. A Constituição, porém, excepciona a competência da Justiça Eleitoral para julgar crimes eleitorais, ainda que de natureza comum, no caso de eles terem sido praticados por Governador de Estado, na prerrogativa constitucional. Nesse caso, a competência é do STJ (art. 105, I, a). Se o crime tiver sido cometido por Prefeito, será decidido no Tribunal de Justiça (art.29, VIII).

O art. 22 do Código Eleitoral trata das competências desse órgão, que incluem o registro e a cassação dos registros de partidos políticos, ${ }^{126}$ e a decisão sobre os

125 Para Marchetti, possuímos um modelo que propicia a judicialização da política. "Uma das consequências mais notórias desse fenômeno pode ser medida em diversos casos recentes quando o TSE, interpretando a legislação de modo arrojado, acabou criando novas regras.” MARCHETTI, Vitor. O "Supremo Tribunal Eleitoral”: a relação entre STF e TSE na governança eleitoral brasileira. Revista Brasileira de Estudos Constitucionais - RBEC, Belo Horizonte, ano 5, n. 20, p. 174, out/dez/2011.

126 Exemplo recente foi a decisão pelo TSE da criação do Partido Republicano da Ordem Social (PROS) e o indeferimento do pedido de criação da Rede. Disponível em: <http://acervo.folha.com.br/fsp/2013/10/04/2/>. Acesso em: 04 out. 2013. 
conflitos de jurisdição entre Tribunais Regionais e juízes eleitorais de Estados diferentes.

O TSE concentra os poderes de regulamentar, administrar e julgar o processo eleitoral brasileiro, e não há qualquer espaço para a interferência do Poder Executivo ou Legislativo, no resultado final das eleições. É uma configuração peculiar, porque há um acúmulo de atribuições, e o órgão se vê sob a reponsabilidade de administrar e operar todo o processo eleitoral, regulamentar os procedimentos, fiscalizar e decidir o contencioso de natureza eleitoral, mesmo quando envolve membros da própria Justiça Eleitoral como parte no processo.

Já os Tribunais Regionais Federais são instâncias de $2^{\circ}$ grau da Justiça Eleitoral e avaliam os recursos. São formados por sete membros, havendo um tribunal instalado na capital de cada Estado, incumbido de coordenar as eleições na sua unidade federativa e de exercer a função de segunda instância jurisdicional.

O art. 120 da CF prevê como se dá a escolha dos membros do TRE, com a escolha de juízes pelos Tribunais de Justiça, que também elaboram uma lista sêxtupla e a remetem ao Presidente da República, dela selecionando dois advogados para completar a composição.

A Lei $n^{0}$ 9.504/97, em seu art. 96, prevê que os Tribunais Regionais são competentes para designar juízes auxiliares a fim de apreciar reclamações ou representações apresentadas durante o período eleitoral.

Como a celeridade é imprescindível, as decisões dos Tribunais Regionais Eleitorais somente são passíveis de recurso ao TSE nos termos do art. 121, § $4^{\circ}$, da CF, ou seja, se houver alguma disposição expressamente contrária à CF, ou houver divergência de lei entre dois ou mais tribunais eleitorais, dentre outros.

Destaca-se, ainda, que esses tribunais são responsáveis pela fiscalização das contas das campanhas políticas, exceto para o cargo de Presidente da República. ${ }^{127}$

127 BRASIL. AG - 8909/SP, Rel. José Augusto Delgado. 
Os Tribunais Regionais Eleitorais escolhem os juízes eleitorais que exercerão o cargo por dois anos (art. 121, $\S 2^{\circ}$, da CF). Esse rodízio possibilita a todos os magistrados essa experiência no campo eleitoral. A esses juízes ${ }^{128}$ aplica-se a Lei Orgânica da Magistratura Nacional (LOMAN), cabendo-lhes exercer a jurisdição eleitoral e a comum.

Por sua vez, o Juiz eleitoral é escolhido pelo TRE dentre os juízes de direito do Estado. A Justiça Eleitoral de primeiro grau está dividida em zonas eleitorais, às quais pertencem os eleitores. O juiz eleitoral de uma zona aprecia e julga todas as questões eleitorais que por ali passarem - essa é a sua jurisdição.

A Junta Eleitoral só atua em ano eleitoral, sendo, pois, um órgão temporário. A função das Juntas é essencial para a fluidez do processo eleitoral, pois são elas que apuram as eleições e realizam a diplomação dos candidatos eleitos. A Junta presta auxílio aos juízes eleitorais, colaborando na resolução da quantidade de conflitos que surgem nessa época para que, assim, os juízes possam exercer as suas funções de forma adequada. Presidida por um juiz de Direito e composta por dois ou quatro cidadãos de notória idoneidade, “[...] as Juntas Eleitorais constituem-se em aspecto peculiar de organização da Justiça Eleitoral, pois são órgãos de primeira instância formados de maneira colegiada”. ${ }^{129}$ Qualquer decisão proferida deve conter a manifestação do Juiz Presidente e de mais dois ou quatro cidadãos, sob pena de nulidade por incompetência absoluta.

Interessante a observação de Marchetti sobre esses órgãos:

Não há no modelo brasileiro um órgão com corpo de direção próprio e exclusivo. Apesar do TSE, dos TREs e dos Cartórios Eleitorais, onde atuam os juízes eleitorais, serem permanentes e, portanto, contarem com um corpo funcional próprio e estável, os juízes e ministros que se tornam membros da Justiça Eleitoral não são obrigados a se desligarem das outras atividades que desempenham nos outros ramos da Justiça. Nem mesmo os advogados selecionados são obrigados a

128 Os juízes eleitorais são obrigatoriamente juízes de Direito, diferentemente do que ocorre nas Juntas Eleitorais, em há um Juiz de Direito e vários juízes leigos.

129 CITADINI, Antonio Roque. Código eleitoral anotado e comentado. 2. ed. São Paulo: Max Limonad, 1985, p. 83. 
interromper suas atividades profissionais. ${ }^{130}$

Essa estrutura, não obstante, tem-se mostrado capaz de conduzir um processo decisório imparcial e de reputação positiva:

Há que se reconhecer que, de um lado, a temporariedade e a cooperação acabam trazendo algumas dificuldades relacionadas ao alto grau de dedicação e especialização necessários para o desempenho das atribuições da Justiça Eleitoral e ao pouco tempo disponível para tanto, dado o apertado calendário eleitoral e o frequente acúmulo de funções entre os magistrados. A experiência demonstra, no entanto, que essas dificuldades práticas acabam sendo superadas pela notável dedicação dos servidores e magistrados. ${ }^{131}$

Existem, ainda, as mesas receptoras, formadas por auxiliares designados pelo Juiz Eleitoral para prestarem serviços gratuitos à Justiça Eleitoral, exercendo atividades administrativas que permitem ao cidadão exercer o direito de voto, todas elencadas no artigo 38 do Código Eleitoral. São formadas por um Presidente, um primeiro e um segundo mesários, dois secretários e um suplente, todos nomeados sessenta dias antes da eleição, por meio de audiência pública, comunicada com cinco dias de antecedência.

Caso fique constatado que algum mesário possui vínculos com algum candidato, pode-se entrar com uma reclamação ao juiz eleitoral, em cinco dias, e dessa decisão cabe recurso para o Tribunal Regional Eleitoral em três dias (Lei n n 9.504/97, art. 63).

O não comparecimento de um dos membros da mesa receptora no dia das eleições leva a uma multa de 50\% de um salário mínimo à época, mas ele pode justificar sua ausência em até trinta dias após a eleição.

O grande destaque da Justiça Eleitoral brasileira está em sua ampla adesão popular, credibilidade e celeridade, que tem garantido resultados legítimos e dificilmente contestados, com aceitação da alternância de poder e preservação das

130 MARCHETTI, Vitor. O “Supremo Tribunal Eleitoral”: a relação entre STF e TSE na governança eleitoral brasileira. Revista Brasileira de Estudos Constitucionais - RBEC, Belo Horizonte, ano 5, n. 20, p. 169, out./dez. 2011.

131 MACHADO, Marcelo Passamini. A Justiça Eleitoral. In: CAGGIANO, Monica Herman S. (Coord.). Direito eleitoral em debate: estudos em homenagem a Cláudio Lembo. São Paulo: Saraiva, 2013, p. 273. 
instituições. É notável a assertiva de Marchetti:

O bem maior para as instituições reguladoras da competição política é a garantia da lisura do processo eleitoral. A legitimidade do resultado das urnas é condição sine qua non para que as principais forças políticas aceitem os resultados eleitorais. Vale ressaltar que boa parte das atividades de governança eleitoral diz respeito à garantia das oportunidades para que grupos políticos distintos vençam as eleições e, principalmente, tenham sua vitória reconhecida e aceita. Só há chance de disputa na medida em que os grupos políticos estão aptos e confiantes para disputar eleições. ${ }^{132}$

Muito contribui para isso a inserção da urna eletrônica no modelo eleitoral brasileiro.

A inserção das urnas eletrônicas chamou a atenção para o eficiente processo eleitoral brasileiro pela credibilidade com a coleta dos votos, que diminui a manipulação humana da contagem e conferência de votos. A manifestação da vontade por meio dessas urnas evita fraudes e propicia apuração de resultados em 24 horas. Citando Nicolau: “[...] pouca gente duvida da legitimidade do processo eleitoral brasileiro. As fraudes foram praticamente eliminadas. A urna eletrônica permite que os resultados sejam proclamados poucas horas depois do pleito."133

Esse processo se tornou tecnologia nacional para exportação e serve de referência mundial, principalmente se comparado ao demorado processo de contagem de votos na maior democracia do mundo, os Estados Unidos. ${ }^{134}$ Curioso observar que parece haver uma separação entre políticos e resultados eleitorais, os primeiros tão

132 MARCHETTI, Vitor. Op. cit., p., 166-167.

133 NICOLAU, Jairo Marconi. História do voto no Brasil. 2. ed. Rio de Janeiro: Jorge Zahar, 2004, p. 8.

134 Nos Estados Unidos, no ano de 2000, houve grande impasse na apuração, e um erro do tipo dimple chads. Às vezes, ao não usar a cédula perfurada para votação, ao invés de perfurar a cédula, o eleitor deixa o espaço ao lado do nome do seu candidato com uma espécie de "barriga”, uma ondulação característica de uma perfuração incompleta, o que gera problemas na aferição do voto pelas máquinas. Isso criou um enorme problema que colocou em suspenso o resultado das eleições presidenciais. Naquele ano, uma das emissoras de televisão mais poderosas do mundo, a FOX, declarou George Bush presidente vitorioso no Estado da Flórida e, consequentemente, nas eleições, e os canais concorrentes acompanharam a notícia. Seguiu-se uma batalha judicial que paralisou o país por semanas e instâncias judiciais contínuas, até a Suprema Corte decidir que a vitória era de George Bush. Recontagens posteriores demonstraram que Bush não havia ganhado na Flórida, onde efetivamente vencera $\mathrm{Al}$ Gore, porém, já era tarde demais para que o erro fosse revertido. Cabe lembrar que a Suprema Corte da época possuía maioria republicana. 
descrentes e desacreditados pela população, e os últimos, tidos como uma referência de retidão.

No ano de 1996, foi introduzida a urna eletrônica nas eleições brasileiras. Bastava que o eleitor digitasse o número de seu candidato ou de seu partido de escolha. Na primeira eleição informatizada da história do país, foi possível assistir a uma aula de democracia e cidadania, que transcorreu no pleito municipal em 57 cidades brasileiras. $^{135}$

Para que isso fosse possível, o TSE conduziu um exaustivo processo de cadastramento para ter um banco de dados que contivesse a grande parcela da população apta a votar nas eleições, tendo que gerenciar esses nomes e suas correspondentes zonas eleitorais, de sorte a conseguir alcançar a máxima efetividade desse novo sistema. Esse processo, pode-se afirmar, teve início em 1982, ano em que foi eliminado da legislação eleitoral o voto vinculado, o qual determinava ao eleitor que, se ele votasse em um partido para o governador, ele teria de votar no mesmo partido para os outros cargos que elegesse, uma herança da ditadura militar. Para as eleições seguintes, seria necessário um cadastramento.

Assim, em 1986, foi realizado o recadastramento de 69,3 milhões de eleitores, em todo o território nacional, sob a supervisão do TSE. ${ }^{136}$ Esse recadastramento foi feito por intermédio de um cadastro numérico nacional, o que possibilitou a identificação de todos os eleitores e viabilizou o voto eletrônico alguns anos mais tarde. O processo de informatização total foi concluído em 2000, ano em que a urna eletrônica foi usada em todo o território nacional, no pleito municipal.

A eficiência para a implantação do sistema da urna eletrônica foi inconteste, e, em seis anos, todos tiveram que deixar as cédulas de papel para trás, aprendendo a definir o futuro do país por um sistema eletrônico.

\footnotetext{
135 Disponível em: <http://www.tse.jus.br/eleicoes/eleicoes-anteriores/eleicoes-1996/municipios-comvotacao-eletronica>. Acesso em: 20 abr. 2013.

136 Disponível em: <http://www.brasil.gov.br/sobre/cidadania/eleições-2010/historia/histoiado-voto-eletronico-no-brasil>. Acesso em: 20 abr. 2012.
} 
Para garantir ainda mais lisura ao processo de votação, desde 2008, tem-se executado um novo cadastramento dos eleitores, agora por meio de impressão digital (biometria), substituindo as cédulas de papel, no intuito de aprimorar o sistema de voto eletrônico brasileiro, que é eficiente, mas pode ficar ainda melhor, sempre buscando a manutenção e a segurança do sistema tecnológico e o zelo com a democracia.

Foi o TSE o órgão a pressionar o governo pela implementação das urnas eletrônicas, resultando na aprovação da Lei $n^{0}$ 7.444/85, que ordenava a unificação do cadastro de eleitores com o uso da computação, ficando o recadastramento a cargo do TSE. ${ }^{137}$ Dez anos mais tarde, novo lobby do TSE no Congresso Nacional resultou na Lei $n^{\circ}$ 9.100/95, que permitiu o uso das máquinas de votar eletrônicas. À frente de seu tempo, o art. 152 da Lei $n^{0} 4.73$ de 1965 já abordava o uso desses mecanismos: "Poderão ser utilizadas máquinas de votar, a critério e mediante regulamentação do Tribunal Superior Eleitoral”.

Em 2002, foi introduzida uma versão que tinha acoplada a si um módulo com uma impressora que produzia um voto físico, mas esse voto impresso foi abandonado pela Lei $n^{\circ} 10.740 / 2003$ e só deverá ser reintroduzido a partir de 2014, segundo o art. $5^{\circ}$ da Lei n ${ }^{0}$ 12.034/2009. Por esse motivo, os modelos de urnas eletrônicas de 2009 e 2010 possuíam um encaixe lateral para o chamado Módulo Impressor Externo, onde futuramente será conectada uma impressora que imprimirá os votos dos eleitores.

Infelizmente, essa novidade trazida pela Lei $\mathrm{n}^{0}$ 12.034/2009 representa um retrocesso na história dos costumes eleitorais do país.

A urna eletrônica "é um microcomputador de uso específico para eleições, com as seguintes características: resistente, de pequenas dimensões, leve, com autonomia de energia e com recursos de segurança”. ${ }^{138}$ Possui sistemas de criptografia e assinaturas digitais. É evidente que é um sistema falível, como, de resto, toda outra máquina ou equipamento produzido pelo homem, também falível. Mas o sistema de impressão de voto cria mais problemas do que certezas, podendo colocar em risco um sistema que

\footnotetext{
137 Naquela época, o TSE que também decidiu eliminar a foto no título eleitor, dando espaço para fraudes.

138 Disponível em: <http://www.tse.jus.br/eleicoes/biometria-e-urna-eletronica/urna-eletronica>. Acesso em: 09 dez. 2013.
} 
tem-se mostrado um dos mais avançados do mundo, em tecnologia de segurança e eficiência.

Para o relator do projeto que culminou na Lei $\mathrm{n}^{0} 12.034 / 2009$, deputado federal Flávio Dino, o voto impresso complementar ao voto eletrônico traria mais segurança ao sistema, porque os votos de papel são, nesse modelo, confrontados com o resultado apurado eletronicamente ${ }^{139}$. Assim, no dia da votação, o eleitor digita os números de seus candidatos e, em seguida, pode ver um “espelho do voto”, nos termos da lei, confirmando ou não seu voto. Se ele entender que o voto está errado, pode corrigi-lo. Entretanto, a lei não tratou do caso de dupla discordância do eleitor, ou seja: se, depois de corrigido o voto, o eleitor verificar o "espelho" e achar que aquilo não condiz com sua intenção, o que ocorre? Além de tumultuar o processo eleitoral, levantando suspeitas sobre a lisura do procedimento e de atrasar o andamento dos trabalhos, o eleitor, provavelmente, terá que votar manualmente, registrando o incidente em ata. Se este for o único caso a acontecer naquela seção, ter-se-á conhecimento do voto e do nome do eleitor, porquanto, a nova lei permite identificação do eleitor na auditoria. Essas são medidas inaceitáveis, pois atingem frontalmente o princípio constitucional do sigilo do voto.

O TSE já passou por uma experiência dessas, em 2002, e o resultado não foi bom. As impressoras acopladas às urnas tiveram muitas falhas, o equipamento era lento, as bobinas travavam, as filas foram longas e os votos impressos acabaram tendo que ser manuseados por Juízes Eleitorais e outros auxiliares, o que é sempre uma preocupação, sem mencionar o significativo aumento do custo.

Em outubro de 2011, uma liminar que suspendia os efeitos desse dispositivo foi concedida pelo STF na Ação Direta de Inconstitucionalidade $\mathrm{n}^{\circ}$ 4543. Tendo em vista a proximidade das eleições de 2014, o Plenário do STF decidiu, no final de 2013, pela inconstitucionalidade do art. $5^{\circ}$ da Lei $\mathrm{n}^{\circ} 12.034 / 2009$, reafirmando os argumentos

139 O modelo funciona, basicamente, assim: a urna eletrônica exibe a relação dos votos do eleitor. Após a confirmação, a urna imprime o voto, depositado automaticamente em um ambiente lacrado, sem ser manuseado pelo eleitor. Depois de apurados os votos, a Justiça Eleitoral sorteia 2\% das urnas de todas as zonas eleitorais, e uma auditoria independente compara os votos em papel com o boletim das urnas eletrônicas. 
firmados no julgamento da liminar de que o dispositivo de impressão de voto fere o sigilo e a inviolabilidade do voto previstos pelo art. 14 da Constituição Federal. 


\title{
CAPÍTULO II - ELEIÇÕES E PARTICIPAÇÃO POPULAR
}

\author{
na rua \\ sem resistir \\ me chamam \\ torno a existir \\ Paulo Leminski ${ }^{140}$
}

\subsection{Sociedade civil}

\subsubsection{Conceito}

Desde Hobbes, ${ }^{141}$ a sociedade civil é identificada como um dos níveis mais elevados do desenvolvimento humano, no qual o homem reconhece suas potencialidades éticas e consegue elaborar uma comunidade política.

O núcleo central do estudo sobre a sociedade civil é a sua diferenciação do estado de natureza, ou seja, é a partir do momento em que o homem usa sua capacidade de raciocínio para suplantar os efeitos daninhos provocados pelo estado de natureza que ele consegue superar esse estado primitivo da humanidade, e a sociedade civil aparece para se tornar sinônimo de sociedade civilizada.

No estado de natureza de Hobbes, cada um era o juiz de suas ações e, por não haver um Estado que instaurasse a ordem e preservasse a vida dos indivíduos, cada um deles representava uma ameaça ao outro, em um ambiente de puro caos.

Hobbes, contratualista, estabelece, assim, uma instância que teria como função primordial a proteção da vida de todos. É a instauração do Estado que faz o homem abandonar o estado de natureza, quando é firmado esse "contrato" o qual estabelece que os indivíduos alienam seus direitos naturais em nome do Estado, soberano absoluto.

140 LEMINSKY, Paulo. Toda poesia. São Paulo: Companhia das Letras, 2013, p. 117.

141 A dicotomia fundamental da origem do Estado encontrada no jusnaturalismo está no estado de natureza x estado civil proposto por Hobbes, em seu Leviatã, escrito em 1651. Conforme o autor inglês, o estado de natureza representava uma condição social sem a presença de um Estado instituído que, por conta disso, transformava os homens em uma ameaça aos olhos de seus pares. Na busca da autopreservação, estariam os homens em constante ambiente bélico, em um estado de guerra de “todos contra todos”. HOBBES, Thomas. Leviatã. São Paulo: Martin Claret, 2004. 
Locke, ${ }^{142}$ no mesmo sentido, idealiza o estabelecimento de um contrato social que faz surgir a sociedade civil, com a superação de um estado de natureza, que, no entanto, era diferente do modelo hobbesiano. De acordo com Locke, havia harmonia e equilíbrio nesse estágio, mas a ocorrência de violações à propriedade privada - que, para Locke, precediam o surgimento do Estado - impunham a presença de um ente que controlasse os direitos naturais do homem. O papel fundamental do Estado é proteger a propriedade privada, direito natural do indivíduo, que antecede o Estado e a sociedade civil.

O pensador genebrino Jean-Jacques Rousseau, apesar de também adotar um modelo de contrato social, traz formulações muito diferentes das de Hobbes e Locke.

Rousseau anota, em seu $O$ contrato social, ${ }^{143}$ que o Estado estava subordinado ao povo, de fato, o verdadeiro soberano. Por isso, o contrato é elaborado para preservar e maximizar a vontade geral ${ }^{144}$ e o interesse comum.

O homem rousseuniano do estado de natureza preocupa-se com a sua sobrevivência e não entra no estado de competição ou guerra com os demais. Como o homem vai ficando mais racional e consciente de suas condições no mundo, ele percebe a necessidade de se socializar, cooperando com os outros indivíduos para o progresso da sociedade, o que implicará seu próprio desenvolvimento. Por conta disso, é fixado um pacto legítimo e voluntário, que gera uma ordem social igualitária.

A interpretação de Hegel rompe a teoria contratualista, por rejeitar a existência de um contrato a marcar a transição do estado de natureza para a sociedade civil. Pela

\footnotetext{
142 A obra, escrita em 1690, novamente realça a relação jusnaturalista, tratando a sociedade civil como uma sociedade com um Estado: "Os que estão unidos em um corpo, tendo lei comum estabelecida e judicatura - para a qual apelar - com autoridade para decidir controvérsias e punir os ofensores, estão em sociedade civil uns com os outros[...]”. LOCKE, John. Segundo tratado sobre o governo civil. São Paulo: Martin Claret, 2005.

143 ROUSSEAU, Jean-Jacques. O contrato social. Trad. Antonio de Pádua Danesi. 4. ed. São Paulo: Martins Fontes, 2006.

144 Vontade geral entendida não como uma soma numérica de vontades particulares, mas como a identificação do que há de comum nas vontades individuais. Para Coutinho, o liberalismo é marcado pela vontade de todos, que é identificada por essa soma de interesses individuais, enquanto a vontade geral está ligada à noção de democracia, pois pressupõe um consenso sobre o que é o interesse comum e o que é melhor para a sociedade. COUTINHO, C.N. Crítica e utopia em Rousseau. Lua Nova, São Paulo, n. 38, p. 23-27, 1996.
} 
sua abordagem, apresentada em sua Filosofia do Direito, de 1821, a sociedade civil exibe uma natureza mais elevada, emancipada de princípios subjetivos e particulares. Por isso, ela não deve mais ser interpretada em função dos interesses egoísticos de cada indivíduo, o que sempre comprometeu sua relação com os demais membros sociais, e acaba por prejudicar a moralidade dos indivíduos. A vontade geral dessa sociedade está assentada sobre uma base objetiva de interesses, que nascem de ligações concretas entre os indivíduos, e não de uma noção abstrata como a de Rousseau. Sua sociedade civil está ligada à eticidade ${ }^{145}$ e, a partir disso, Hegel elabora sua ideia de Estado.

Esclarece Rosenzweig: “A eticidade mesma não lhe é senão apenas uma parte da filosofia do Espírito 'objetivo', e esta, é uma parte da filosofia do Espírito [...], ‘Espírito’ como unidade superior entre pensamento e objeto, entre lógica e natureza.»146

A vontade do indivíduo hegeliano é racional, e ela é conduzida de forma a penetrar no Estado. É dessa vontade, que é a própria inteligência ou “[...] o sangue especial que fluía pelas artérias deste organismo estatal”, ${ }^{147}$ que deriva a formação do Estado. Esse indivíduo verdadeiramente ético reconhece o conteúdo essencial do Estado, que é soberano, e deve ser construído e preservado, fazendo com que as ideias éticas da sociedade e da família soem em acorde.

Hegel apresenta a sociedade civil sob três diferentes vértices. Um deles diz respeito ao mundo privado e familiar. O segundo retrata a ligação da sociedade civil com um sistema de instituições, indicadas pelas corporações, pelo Judiciário e pela polícia. Por fim, há um aspecto estatal da sociedade civil, representado por um Estado nacional e internacional. Esse Estado não nasce de um pacto ou contrato, nem é fruto da passagem do estado de natureza para o estado civil; ele deriva de um princípio racional

\footnotetext{
145 HEGEL, G.W.F. Filosofia do direito. Trad. Orlando Vitorino. 2. ed. São Paulo: Martins Fontes, 2003. $\S \S 182-256$.

146 ROSENZWEIG, Franz. Hegel e o Estado. Trad. Ricardo Timm de Souza. São Paulo: Perspectiva, 2008, p. 410.

147 ROSENZWEIG, Franz. Op. cit., p. 412.
} 
e universalizante, fazendo a intermediação entre público e privado, por intermédio de suas instituições. ${ }^{148}$

Hegel afirma, ademais, que o bem-estar do indivíduo está ligado ao bem-estar de todos, por isso surgem as associações, ${ }^{149}$ nas quais os indivíduos desenvolvem noções de cooperação que serão vitais em uma organização democrática.

O direito de associação é marcado, anos mais tarde, em 1835, na obra de Tocqueville. Ao se aprofundar no conceito de democracia na América, ${ }^{150}$ o autor entende que sociedade civil são os interesses privados associados, uma forma de os cidadãos fazerem valer seus desejos diante do Estado, incluindo o direito de se opor ao poder central e o de interferir nas instituições, para conquistar um bom governo.

Há diferentes maneiras de se servir desse direito de associação. Ele pode ser caracterizado pela adesão pública de um número qualquer de indivíduos que se associam em busca de um objetivo claramente definido. Essa associação não é tão forte ou influente quanto uma associação política, a qual possui foco de ação mais amplo, de alcance nacional, e exerce influência sobre um grande grupo. O grau mais amadurecido desse direito de associação está na formação de colégios eleitorais, da qual saem os mandatários que farão a representação dos associados em uma assembleia central, o que seria o próprio sistema representativo. E ressalta: “Na América, a liberdade de se associar com finalidades políticas é ilimitada.”151

O direito de associação só existe em função do valor dado à liberdade e à igualdade na vida social da América.

148 Com isso, “[...] Hegel acaba também por legitimar a necessidade do pluralismo político-institucional. É com essa mediação que os indivíduos singulares passam de massa informe a sujeitos organizados em seus interesses, e é por meio dela que os defendem.” DURIGUETTO, Maria Lúcia. Sociedade civil e democracia: um debate necessário. São Paulo, Cortez, 2007, p. 46.

149 “O mérito de Hegel constitui em lhe atribuir, com plena consciência, um sentido altamente restritivo: ele chama de sociedade a vida humana em comum no interior de associações relativamente amplas, mesmo no Estado e para além dele, na medida em que ela não se constitui na vida do Estado mesmo, mas estabelece relações mais ou menos abrangentes com o Estado. Com isso, ele estabeleceu a possibilidade de acolher em seu sistema um conceito jusnaturalista da relação entre o homem e a sociedade, sem lhe permitir assumir a posição dominante.” ROSENZWEIG, Franz. Op. cit., p. 450.

150 TOCQUEVILLE, Alexis de. A democracia na América: leis e costumes de certas leis e certos costumes políticos que foram sugeridos aos americanos por seu estado social democrático. Livro I. Trad. Eduardo Brandão. 2. ed. São Paulo: Martins Fontes, 2005, p. 218-227.

151 TOCQUEVILLE, Alexis de. Op. cit., p. 222. 
Só que essa igualdade política, que implica considerar os cidadãos livres e iguais, será questionada por Marx. Os interesses particulares, a propriedade privada e as relações capitalistas de produção geram diferenças entre os cidadãos, e essa desigualdade de classe econômica provoca consequências na esfera política. O Manifesto do Partido Comunista, ${ }^{152}$ de Marx e Engels, conclui que o Estado depende do poder econômico e obedece às determinações da classe dominante, que se vale da opressão da classe trabalhadora para manter-se no poder. É pela luta que os trabalhadores tomarão o poder, socializando os meios de produção e fazendo com a sociedade deixe de se calcar sobre bases materiais.

Bobbio faz conhecida observação sobre a teoria de Gramsci e afirma que esse cientista político trouxe grande inovação à visão marxista, a partir do momento em que incluiu a sociedade civil na superestrutura, como parte do Estado, ${ }^{153}$ e não na infraestrutura econômica, como aduzia Marx, trabalhando de forma detalhada a proliferação dos movimentos de massa provocada pelos sindicatos, partidos e associações. $^{154}$

Dessa forma, para Gramsci, ${ }^{155}$ a sociedade civil faz parte do Estado integral, e é imprecisa a separação entre estrutura e superestrutura, pois os dois momentos são dialeticamente estruturados, sendo a leitura da correlação de forças em um dado período concreto que revelará maior importância de um ou de outro. São instâncias distintas, porém, articuladas, em que há uma combinação de força (Estado) e consenso (sociedade civil). A sociedade civil é o local em que ocorre a luta de classes pela hegemonia, concebida como a capacidade de determinada classe dirigir moral e intelectualmente

152 MARX, Karl; ENGELS, Friedrich. Manifesto do partido comunista. São Paulo: Cortez, 1998.

153 “Enquanto em Marx o momento da sociedade civil coincide com a base material (contraposta à superestrutura onde estão as ideologias e as instituições), para Gramsci o momento da sociedade civil é superestrutural”. BOBBIO, Norberto. Estado, governo, sociedade. Trad. Marco Aurélio Nogueira. 3. ed. Rio de Janeiro: Paz e Terra, 1997, p. 39.

154 Coutinho alerta que o fato de Gramsci ter dado ênfase à análise da superestrutura e ter relegado a esfera infraestrutural a uma segunda posição não significa que a esfera econômica não seja fundamental para o estudo da sociedade civil. Gramsci apenas opta por enfatizar a superestrutura, sem deixar de reconhecer as complexas intermediações econômicas, culturais e institucionais que a permeiam. A dominação cultural/simbólica é, muitas vezes, mais eficiente para a atuação da sociedade civil que a própria categoria econômica que, assim, é um dos fatores de conformação da sociedade, mas não o único. COUTINHO, C.N. Democracia e socialismo. São Paulo: Cortez, 1992, p. 73.

155 GRAMSCI, Antonio. Cadernos do cárcere. Vol. 3. Rio de Janeiro: Civilização Brasileira, 2011. 
toda a sociedade. A conquista da hegemonia pressupõe o desenvolvimento de uma consciência crítica, pela qual o ser social constrói sua própria história e se envolve ativamente com os demais atores sociais, saindo de uma situação de passividade e manipulação. Com isso, tem-se a superação dos interesses individuais em nome da construção da consciência ético-política, com a consequente formação de grupos com os mesmos valores ideológicos e os quais superam seus limites até que seja concretizada a hegemonia. Assim, em Gramsci,

[...] a formação de uma consciência crítica, assim como a participação ativa são os alicerces de uma ação política que procura conquistar a hegemonia, uma vez que, se não é a consciência que determina o ser social, é por meio desta que os sujeitos sociais podem construir sua "eticidade” e sua própria história. A práxis política constitui, desse modo, o campo particular de mediação e formação de cultura, do consenso e da construção de uma nova hegemonia. ${ }^{156}$

Esses sujeitos ativos e conscientes de seu papel social, todavia, podem estar dispersos na sociedade. O papel agregador e mediador será exercido pelo partido político, que assume a função de direção e articulação desses grupos em movimentos sociais organizados e fortalecidos, os quais se movem com o intuito de atingir seus objetivos. Se o capitalismo fragmenta os interesses de classe, o associativismo cimenta uma organização política, mas desde que seja considerado politicamente.

A evolução do conceito de sociedade civil, nos termos de Gramsci, passa, portanto, por transformações significativas, saindo de uma posição subordinada ao Estado, ou mesmo separada dele, para uma outra, na qual tem de conviver com esse Estado, na tentativa de, assim, conquistar seus interesses. Durigueto é mais uma vez mencionada, pela precisão da análise:

[Gramsci] elabora, assim, um novo conceito de sociedade civil, diferenciando-o da tradição jusnaturalista (sociedade civil não é a esfera das liberdades econômicas, dos contratos); não está orientada em função do Estado (como queria Hegel), nem se reduz ao espaço exclusivo das relações econômicas e da hegemonia burguesa, tal como Marx a definira. Mas em Gramsci, sociedade civil é a esfera em que as classes organizam e defendem seus interesses e disputam a hegemonia. ${ }^{157}$

\footnotetext{
156 DURIGUETO. Maria Lúcia. Sociedade civil e democracia: um debate necessário. São Paulo: Cortez, 2007, p. 63.

157 DURIGUETO, Maria Lúcia. Op. cit., p. 55.
} 
Sob uma perspectiva social-democrata, John Rawls ${ }^{158}$ apresenta sua teoria da política da justiça como equidade (justice as fairness), que pressupõe uma deliberação racional dentro do contexto democrático que, por meio de suas instituições, chegaria a um critério distributivista. São esses critérios e recursos que permitem a inclusão social e que reconhecem aqueles mais excluídos como reais sujeitos de direitos.

Rawls $^{159}$ reforça a ideia de contrato entre os indivíduos para fortalecer um sistema de liberdades a ser partilhado por todos, em função do atuante papel da justiça, que deve se impor para favorecer quem tem menos oportunidades sociais.

A crítica que se faz é que Rawls parece não levar em conta os conflitos internos, que pressionam as mudanças. A Justiça pode construir leis que expressem um pacto de respeito e igualdade, mas ela não atua sozinha, pois a sociedade é dinâmica e vários atores interferem em suas transformações. A democracia é constitutiva da cidadania, que, por sua vez, é construída de forma lenta nas lutas sociais pelo direito de voto, nas quais se organizam diversos partidos que promovem programas, criando novas pactuações políticas para garantir o direito de todos a uma sociedade livre e justa. Não é apenas uma instituição, mas as instituições, o Estado, os cidadãos e a economia, um amplo conjunto correlacionado que alcança a sociedade democrática.

Como se vê, o século XX exibe um profundo debate sobre o conceito de sociedade civil, explicitado de vários ângulos, por autores de forte influência na literatura política e acadêmica, e volta a ser foco das atenções com a crise nos países da Europa Central, que presenciou a liderança da sociedade civil nos movimentos pela queda dos regimes comunistas e pelo retorno à democracia. O modelo do Estado onipotente e a centralidade do partido único foram rechaçados, com o propósito de ampliação do espaço da sociedade civil.

Na América Latina, entre as décadas de 1970 e 1980, houve igualmente o ressurgimento de organizações e movimentos populares, sindicatos, partidos de

\footnotetext{
158 RAWLS, John. Justiça como equidade: uma concepção política, não metafísica. Lua Nova, São Paulo, vol. 25, p. 25-60, 1992.

159 RAWLS, John. Uma teoria da justiça. Brasília: Editora UnB, 1981.
} 
esquerda que fizeram a sociedade pensar sobre a elaboração de novos projetos sociais que colocariam fim às ditaduras militares.

Ao mesmo tempo, Europa e Estados Unidos debatem a crise do Welfare State, que, apesar das conquistas alcançadas e oferecidas à população, no campo dos direitos sociais e da melhoria de funcionamento das instituições, precisava ter uma sociedade mais atuante, que gerasse novos movimentos sociais a questionar o próprio papel do Estado. Teóricos como Jürgen Habermas, Pierre Rosanvallon e Boaventura de Souza Santos, assim como Francisco Weffort, Leonardo Avritzer e Gurza Lavalle, elaboram diversas propostas para uma nova sociedade civil, com forte apelo à participação direta de seus membros, o que provocou o surgimento de novos atores sociais, representados pelas cooperativas, partidos de esquerda, organizações não governamentais, para citarmos apenas alguns. Não há mais apenas sociedade civil de um lado e Estado do outro, e a sociedade não tem que depender do Estado: ela pode criar formas de cooperação que incluam os excluídos e atenuem as desigualdades sociais. A pluralidade de novos grupos sociais “[...] favorece a participação interativa e a formação de uma esfera pública na qual as ações do Estado e do mercado são limitadas e/ou influenciadas pela sociabilidade associativa”. ${ }^{160}$

Lavalle ${ }^{161}$ acentua que esses novos atores excluem os sujeitos políticos tradicionais personificados pelos partidos políticos, igrejas e universidades, os quais promoveram, outrora, reflexões substanciais sobre o papel do cidadão. Há uma reestruturação da comunicação na esfera pública, que se reporta e um “diálogo público civilizado”, ${ }^{162}$ que “[...] busca expandir e proteger espaços para a liberdade negativa e a liberdade positiva, e recriar formas igualitárias de solidariedades sem prejudicar a autorregulação econômica”. 163

É no final dos anos 1990 que Anthony Giddens ${ }^{164}$ propõe sua “Terceira Via”, concebendo a sociedade civil como um sujeito de cooperação a representar uma das

\footnotetext{
160 COSTA, S. A democracia e a dinâmica da esfera pública. Lua Nova, São Paulo, n. 36, p. 59, 1995.

161 LAVALLE, G.A. Crítica ao modelo da nova sociedade civil. Lua Nova, São Paulo, n. 47, 1999.

162 HABERMAS, Jürgen. Teoria de la acción comunicativa. Madrid: Taurus, 1987, p. 57.

163 AVRITZER, L. (Org.). Sociedade civil e democratização. Belo Horizonte: Del Rey, 1994, p. 17.

164 GIDDENS, Anthony. The third way: the renewal of social democracy. Cambridge: Polity Press, 1998.
} 
esferas decisivas de poder, em conjunto com o governo (Estado) e a economia, isto é, não há mais o afastamento da figura do Estado, que é visto como outra peça essencial do jogo para a reconstrução da sociedade civil. Esses três pilares atuam em conjunto, o que muito agradou aos neoliberais. Afinal, a sociedade civil torna-se despolitizada, ela não é mais um espaço de conflitos, ela atua pontualmente, cada comunidade da sociedade civil pensa na representatividade do seu próprio grupo e deixa projetos políticos globais de lado. As organizações em geral, como as mencionadas ONGs, fundações e voluntariado, alinham-se ao Estado, executando políticas que complementam suas funções e, ao mesmo tempo, controlando os eventuais conflitos que possam surgir. É como se elas estivessem plenamente imbuídas de um espírito de generosidade e cooperação gratuita, para promover o desenvolvimento da democracia em suas comunidades. Explana o autor:

\begin{abstract}
Os movimentos sociais proporcionam vislumbres de futuro possíveis e são em parte veículos para sua realização. Mas é essencial reconhecer que [...] eles não são necessariamente a única base de mudanças que podem conduzir a uma mundo mais seguro e humano. Outras influências, contudo, influindo a força da opinião pública, as políticas das corporações de negócios e dos governos nacionais, e as atividades de organizações interacionais, são fundamentais para a obtenção de reformas básicas. [..] O poder, em seu sentido mais amplo, é um meio de conseguir que as coisas sejam feitas. ${ }^{165}$
\end{abstract}

A sociedade civil se volta aos seus interesses privados e deixa de representar um espaço de luta de classes. Com isso, a prática política se esvai, o que se mostra uma tendência contrária à democracia. O apelo por uma maior participação popular não decorre de uma construção cidadã, mas de uma manipulação das elites, demonstrando que a sociedade é homogênea, um ambiente onde os cidadãos e os movimentos sociais estão preocupados com o bem-estar geral, um espaço que significa a “[...] tradução concreta da consciência benemérita dos cidadãos, dos grupos organizados, das empresas e das associações.”166

\footnotetext{
165 GIDDENS, Anthony. As consequências da modernidade. Trad. Raul Ficker. São Paulo: Editora da UNESP, 1991, p. 161.

166 NOGUEIRA, M.A. Sociedade civil, entre o político-estatal e o universo gerencial. Revista Brasileira de Ciências Sociais, São Paulo, v. 18, n. 52, p. 57, 2003.
} 
Retornando a Duriguetto, ${ }^{167}$ a autora entende que Gramsci, nesse seu percurso de construção de um novo projeto societário, não esclarece como seria possível articular a pluralidade de organizações da sociedade civil com fins de construir uma democracia socialista. Volta-se a autora, então, aos escritos de dois autores, Togliatti e Ingrao, para a formulação dessa resposta.

Togliatti entende que a pluralidade de organizações deve buscar os institutos representativos democráticos tradicionais para unir a sociedade civil em torno de consensos, em um processo de fortalecimento institucional que superaria o capitalismo de forma gradual, por intermédio de reformas econômicas conduzidas pelas instituições e que resultariam em uma sociedade socialista.

Para Ingrao, o processo de unificação de consensos surgiria de dentro dos próprios espaços plurais, e a unidade social viria de alianças feitas entre as várias camadas sociais para atingir reivindicações necessárias e profundas, que transformariam as próprias instituições:

A centralização [...] nos institutos de democracia política significa a luta pela criação, em todos os espaços, de movimentos populares organizados, fortes, conscientes de seus objetivos políticos e capazes de realizá-lo através de ações e lutas unitárias. Tal como em Gramsci, a instância articuladora dessa unidade é o partido político. Caberia ao partido a construção dessa mediação que seria tecida na superação das limitações das posições corporativas e setoriais da sociedade civil pela projeção unitária de sua ação sócio-política a partir da síntese de suas problemáticas. ${ }^{168}$

Deixando de lado o ideal que almeja alcançar uma sociedade socialista - termo desgastado e que parece ter perdido a utilidade, no mundo atual - parece evidente que a sociedade civil se encontra em um processo de embate entre suas estruturas política, econômica e cultural, o qual precisa ser repensado de forma célere. A identificação com o terceiro setor não tem ampliado o horizonte emancipatório da sociedade, que tampouco é um espaço da razão e do agir comunicativo, e nem pode ser reduzida à identificação com o mercado, como quer o neoliberalismo. A sociedade precisa das

\footnotetext{
167 DURIGUETO, Maria Lúcia. Op. cit., p. 68-72.

168 DURIGUETO, Maria Lúcia. Op. cit., p. 69.
} 
instituições intermediárias de articulação de poder, no entanto, essas instituições, principalmente o partido político, também carecem de reformulação e aprimoramento. Por isso, o que se propõe é um fortalecimento da sociedade civil pela Internet, uma nova esfera pública democrática que atrai cada vez mais diferentes camadas sociais, colocando-as diante de orientações diversas e discursos multifacetados, possibilitando uma mediação dos processos de interação social e uma nova base de construção da sociedade política.

Nesse diapasão, preciosa é a revisão do conceito de sociedade civil trazida por Pérez Luño e seu cibercidadão. O autor aborda o tema da teledemocracia, termo que designa o conjunto de teorias e fenômenos que tratam dos avanços tecnológicos nos processos de participação política. Seus elementos constitutivos possuem três exigências básicas: do ponto de vista metodológico, deve haver aplicação das tecnologias em larga escala, conforme proporcionado pela televisão e Internet; quanto ao seu objeto, essas TICs devem se projetar sobre processos de participação política dos cidadãos; em relação à sua aplicação, as tecnologias de comunicação só podem ser usadas com esse propósito nas sociedades democráticas. ${ }^{169}$

Essa projeção das novas tecnologias, notadamente, da Internet, sobre as esferas política e jurídica da sociedade representa o futuro da cidadania, que pode ser interpretada de duas formas: uma positiva, que significa o uso autêntico, democrático e éticos dessas ferramentas no incentivo à participação política, que, em um última instância, resultaria em uma participação com vocação planetária (cibercidadania); e uma negativa, que trata do cidadãos como meros sujeitos passivos, manipulados pelos poderes público e privado (cidadania.com). ${ }^{170}$

Assim, vislumbra-se uma sociedade civil que pode se valer dos sites, blogs, twitter e facebook para buscar uma aproximação entre candidatos e eleitores; que pode criar um canal direto com a Administração, tornando os serviços mais eficientes e a

169 PÉREZ-LUÑO, PÉREZ LUÑO, Antonio Enrique. ¿CibercidadanÍ@ o ciudadaní@.com? Barcelona: Gedisa, 2004, p. 60.

170 PÉREZ-LUÑO, PÉREZ LUÑO, Antonio Enrique. Op. cit., p. 100: “[...] una ciubercidadanía, que implique un nuevo modo más auténtico e instalado en los parâmetros tecnológicos del presente, pra una participación con vocación planetária; [...] un polo negativo, que pueden incubar una indeseable ciudadanía.com". 
Administração mais transparente; uma sociedade que pode dar sua opinião sobre diferentes ações governamentais e propor novos projetos. Enfim, uma sociedade civil articulada, a qual se manifesta em rede e promove o fortalecimento da cultura cívica.

Obviamente, problemas há para sua implementação, muitos deles já debatidos por outros autores, ${ }^{171}$ que ressaltam a apatia política para que haja esse engajamento ou a falta de maturidade política para essa ingerência. Todavia, os pontos positivos da cibercidadania suplantam os negativos, e o que pode ocorrer no futuro próximo é o uso das novas tecnologias para renovar e melhorar o processo político das sociedades democráticas, porquanto essas ferramentas podem propiciar uma nova forma de participação cidadã, com maior estímulo à operação democrática direta e semidireta, que poderá regular as disfunções dos sistemas eleitorais ou, ainda, será eficaz no combate à corrupção. Ademais, a telemática pode atenuar ou até mesmo eliminar a manipulação da opinião pública, já que pesquisas e sondagens instantâneas pela Internet reduziriam a probabilidade de se usar a opinião pública de forma tendenciosa, de sorte a possibilitar que mais cidadãos se manifestassem, e não apenas grupos pequenos e específicos. $^{172}$

O poder político deriva da sociedade civil. O povo possui direitos políticos efetivos e deve conhecê-los e saber usá-los, para que ocorram avanços na sociedade. Um governo democrático tem que respeitar os cidadãos e neles fazer despertar a consciência de que eles possuem o poder. Deve-se resgatar o sentido de povo como elemento constitutivo do Estado, e não um objeto de suas ações ou um ser passivo que acata suas ordens e reformas sem protestar. Urge que a sociedade civil e o seu povo, constituído pelos cidadãos, busque uma ressignificação, para além de sua concepção clássica, agindo e se organizando para conquistar a inclusão e o respeito aos direitos fundamentais. Governar democraticamente é organizar a maneira de repartir o poder com os cidadãos e fazer a todos corresponsáveis pela tomada de decisões que busquem a satisfação das necessidades coletivas. Democracia, não é simplesmente um sistema

\footnotetext{
171 SARTORI, Giovanni. Op. cit. Ou, ainda, Cass Sunstein, que faz críticas mais moderadas, no sentido de que se deve reconhecer que as novas tecnologias devem ser usadas no processo político, mas com calma, já que o acesso de muitas pessoas a muitas informações pode dificultar o consenso e a coesão estrutural da sociedade. Cf. SUNSTEIN, Cass. Republic.com. Princeton: University Press, 2001.

172 PÉREZ-LUÑO, PÉREZ LUÑO, Antonio Enrique. Op. cit., p. 74-84.
} 
político, mas um modo de conviver socialmente, resolvendo os conflitos de forma pacífica.

\subsubsection{Relação entre sociedade civil e Estado}

As democracias do final do século XX e do século XXI continuam a enfrentar grandes desafios, agora com a presença de novos personagens. A crise de representatividade afastou a sociedade civil dos partidos políticos, e a carência de novas ideologias provocou a pressão pela reconstrução de sistemas políticos e modelos de governança capazes de oferecer propostas de governabilidade. Além disso, possibilitaram o surgimento de movimentos sociais que se apropriam desse papel de representantes dos interesses e das demandas dos cidadãos, os quais são impactados pelos meios de comunicação, ${ }^{173}$ como as mídias sociais, capazes de estimular o debate e aproximar o Estado da sociedade.

Manuel Castells assevera que ocorre uma nova forma de relação entre economia, Estado e sociedade, resultado da revolução tecnológica que está na base da “sociedade de informação.”174 Essa transformação sofre constante mudança, dados os efeitos do fenômeno da globalização e revolução tecnológica da informação, que não para de surpreender o mundo. Freitas ilustra a situação:

Nunca pareceu tão claro a todos que a história não é linear nem apenas uma relação de causa-efeito, passível de ser apreendida mediante um mero esforço de análise das variantes envolvidas. Talvez tenhamos, como nunca, a verdadeira noção do que significa a palavra complexidade. Hoje também é mais fácil admitir que apenas um conhecimento inter e multidisciplinar permitirá entender melhor essa

173 Os meios de comunicação representados, ao longo da história, pela imprensa, jornais, rádio, televisão, Internet ou celular, sempre influenciaram o comportamento político, apesar da falta de uma legislação mais assertiva: "O Estado brasileiro manteve, durante dois séculos, um comportamento opaco em relação às políticas públicas de comunicação. Não obstante existissem diretrizes para regular o sistema nacional de comunicação massiva, primeiro a imprensa e depois a mídia eletrônica, ele nunca esteve articulado num corpo doutrinário autônomo. [...] Em termos constitucionais, a única política transparente durante o Império ou a República foi a do controle da imprensa. Mantivemos uma atitude pendular entre a garantia da liberdade de expressão e a punição dos abusos cometidos. [...] Os longos períodos autoritários da nossa organização política deixaram marcas profundas no ethos brasileiro. Tanto assim que, ao impor-se a comunicação como tema relevante da agenda internacional, na segunda metade do século XX, nosso comportamento diplomático foi de hesitação e dubiedade.” MELO, José Marques de. A esfinge midiática. São Paulo: Paulus, 2004, p. 310. Importante é também indagarmos se essas plataformas melhoram ou não a qualidade da democracia.

174 CASTELLS, Manuel. A sociedade em rede. A era da informação: economia, sociedade e cultura, v. 1. Trad. Roneide Venancio Majer. 6. ed. São Paulo: Paz e Terra, 2012. 
realidade multifacetada. As sociedades, em geral, e os indivíduos, em particular, têm sofrido os impactos desse vendaval que está sendo chamado de sociedade da informação, terceira onda, sociedade pósindustrial, era da comunicação, sociedade de serviços ou ainda sociedade do conhecimento. ${ }^{175}$

Para melhor compreender os movimentos sociais, é interessante recuperar as diversas correntes sociológicas que tentam, desde os anos 1930, ${ }^{176}$ estabelecer definições e constatações sobre esses fenômenos.

Entre os anos 1930 e 1960, predominou a teoria da desmobilização política. ${ }^{177}$ A socióloga Ângela Alonso destaca os estudos conduzidos por Adorno e Riesman, que insistiam na prevalência do particular, na primazia do indivíduo sobre a sociedade, situação que floresceu graças à evolução do capitalismo na sociedade de massas, o qual estimula o consumo e a prevalência dos interesses pessoais. O enfoque abordado é o da psicologia social e envolve a análise de atitudes e opiniões individuais. $\mathrm{O}$ acontecimento de uma mobilização social nesse cenário era pouco provável e, mesmo que viesse a acontecer, não seria canalizada pelas instituições da época. Aliás, é a construção desse perfil individualista que propicia a ascensão da personalidade autoritária ${ }^{178}$ e preconceituosa, que não aceita um modelo contrário aos seus interesses e resulta no aparecimento dos sistemas totalitários da época. Os movimentos sociais, sob esse prisma, eram formas irracionais de comportamentos coletivos.

O enfoque muda a partir dos anos 1960, com o surgimento de várias mobilizações sociais na Europa e nos Estados Unidos. Ainda não eram manifestações políticas, no sentido de tomada do poder estatal, mas movimentos que defendiam o pacifismo - consequência evidente depois das grandes guerras, principalmente na Europa - e lutavam pelos direitos civis, buscando o reconhecimento da mulher na

175 FREITAS, Maria Esther. Cultura organizacional: identidade, sedução e carisma. Rio de Janeiro: Editora FGV, 1999, p. 30-31.

176 Em termos práticos, é inegável que já havia, muito antes desse período, associações, passeatas, grupos de pressão, propostas de mudanças anunciadas através da imprensa e outras formas de reivindicação. Adotamos a abordagem feita por Alonso, por entendermos que é a partir desse período que as identidades coletivas são formadas e, com isso, conseguem identificar seus interesses de maneira mais clara, criando estruturas unificadas e negociando com autoridades.

177 Termo usado por Alonso em suas pesquisas sobre o tema: ALONSO, Ângela. As teorias dos movimentos sociais: um balanço do debate. Lua Nova, São Paulo, nº 76, p. 50, 2009.

178 Para aprofundamento do tema, recomenda-se a leitura da obra A personalidade autoritária, de T. W. Adorno, iniciada em 1944 e publicada em 1950, cujas pesquisas refletem sobre o alheamento do indivíduo e as condições para o desenvolvimento do indivíduo potencialmente fascista. 
sociedade. Todavia, por terem nascido de ações sociais e ocorrerem fora das instituições políticas, podem, sem dúvida, ser chamados de movimentos sociais.

No final dos anos 1970, explica Alonso, aparece a Teoria de Mobilização de Recursos (TMR), cujo enfoque não era a entender o porquê da mobilização em si, mas entender o processo de formação dessa mobilização, que só era viável quando bem calculados seus benefícios e custos e que só atingiria seus objetivos, se tivesse uma infraestrutura racional e hierarquizada, ativistas e apoiadores, além de recursos financeiros capazes de assegurar vida longa ao movimento. Era uma teoria que equiparava a ação social a uma empresa e que, por isso mesmo, recebeu muitas críticas, abrindo espaço para as outras duas teorias dos movimentos sociais: a Teoria do Processo Político (TPP) e a Teoria dos Novos Movimentos Sociais (TNMS).

Ambas repelem a ênfase no papel da economia e da burocracia como variáveis dessas ações, a primeira valorizando a mobilização política e a segunda estribando-se na teoria da mudança cultural.

Charles Tilly é a principal referência no que tange à TPP. Através de sua obra From mobilization to revolution, o autor mostra que é necessária uma coordenação entre “[...] solidariedade, produto de catnet, isto é, da combinação entre o pertencimento a uma categoria (catness) e a densidade das redes interpessoais vinculando os membros do grupo entre si (netness).” ${ }^{179}$ Contudo, a solidariedade em si não gera ação; ela também depende de recursos materiais, mas eles não são prioritários: como na primeira teoria, eles são um acessório da ação política.

De acordo com Cohen e Arato, ${ }^{180}$ a obra de Tilly conclui que a ação coletiva pressupõe o desenvolvimento da autonomia do social e a existência de espaços políticos democráticos, com instituições representativas e capazes de garantir direitos. O ponto fraco da teoria é ela não conseguir vislumbrar a possibilidade de novas organizações ou espaços sociais, nem uma nova identidade coletiva. Ele enfrenta somente a dimensão

\footnotetext{
179 ALONSO, Ângela. Op. cit., p. 55.

180 COHEN, Jean; ARATO, Andrew. Civil society and political theory. Massachusetts: The MIT Press, 1982.
} 
relevante para a análise da mobilização de um grupo específico que compete pelo poder e pela realização de seus interesses. ${ }^{181}$

A Teoria dos Novos Movimentos Sociais (TNMS) reúne, dentre seus principais teóricos, Touraine, Habermas e Melucci. ${ }^{182}$

Os ensinamentos de Alan Touraine ${ }^{183}$ têm por base a emergência de um novo tipo de sociedade, chamada, a princípio, de “sociedade programada” e, depois, de “sociedade pós-industrial”. O autor percebe o deslocamento dos conflitos, que antes tinham foco na relação indústria e trabalho, e passa a ser uma pressão social por novas formas de vida e novas conquistas, tudo isso possibilitado pelo avanço das instituições democráticas e pela expansão dos direitos:

Os novos sujeitos não seriam, então, classes, mas grupos marginais em relação aos padrões de normalidade sociocultural. Isto é, poderiam vir de todas as minorias excluídas (Touraine lista negros, hispânicos, índios, homossexuais, mulheres, jovens, velhos e intelectuais) e teriam em comum uma atitude de oposição. Seus exemplos principais são os movimentos feminista e ambientalista. ${ }^{184}$

Habermas constrói igualmente teorias relativas aos processos de construção de identidades, nas quais os sujeitos elaboram sentidos e significados para suas ações, a partir do próprio agir coletivo. O Estado cresceu e passou a ter um papel regulador, porém, não conseguiu dar conta das políticas sociais, o que alimentou a interação social e a “colonização do mundo da vida”. O ator só pode executar seu plano de ação, se tiver a ajuda de outro ator, de sorte que se tem o compartilhamento de ideias resultantes de interações linguísticas intersubjetivas entre os participantes de uma comunidade. ${ }^{185}$

Observa Alonso que, para Habermas,

181 COHEN, Jean. Strategy or identity: new theoretical paradigms and contemporary social movements. Social research, Nova York, v. 52, nº 4, p. 663-716, 1985.

182 ALONSO, Ângela. Op. cit., p. 59.

183 TOURAINE, Alan. O retorno do actor: ensaio sobre sociologia. São Paulo: Instituto Piaget, 2006.

184 ALONSO, Ângela. Op. cit., p. 60.

185 HABERMAS, Jürgen. Teoria de la acción comunicativa. Madrid: Taurus, 1987. O autor estabelece uma oposição entre o mundo da vida e os sistemas, o que equivaleria à oposição entre economia e política, ou, ainda, o símbolo de passagem das sociedades arcaicas para as modernas. 
[o]s genuinamente "novos" movimentos sociais seriam os insurgentes contra a colonização do mundo da vida, contra os papeis institucionalizados de consumidor da sociedade de mercado, de cliente dos serviços públicos do Welfare State, e mesmo de cidadão, fazendo a crítica das instituições políticas. Seriam propositores de novas formas de cooperação e de comunidade. Os exemplos: os movimentos de jovens, o alternativo, o ambientalista e o pacifista. ${ }^{186}$

O italiano Alberto Melucci, no mesmo sentido, argumenta que o capitalismo não se apoia mais apenas no controle da força de trabalho, exercendo influência sobre as relações sociais e a identidade individual. Na “sociedade da informação”, há um novo padrão de dominação e as zonas de conflito são qualificadas pelas próprias relações interpessoais de consumo, lazer, relações com o ambiente, dentre outras. Assim, a ação dos movimentos está “[...] estritamente entrelaçada com a vida cotidiana e com a experiência individual”, ${ }^{187}$ havendo uma autonomia cada vez maior em relação aos sistemas políticos.

Define movimento político como “[...] uma forma de ação coletiva (a) baseada na solidariedade, (b) desenvolvendo um conflito, (c) rompendo os limites do sistema em que ocorre a ação.” ${ }^{188}$ Assim, exige-se dos atores que eles se sintam parte de uma unidade social e que reconheçam seus pares (solidariedade). A partir do momento em que dois atores quiserem se apropriar de algo em comum, surge o conflito.

Melucci condena as teorias que tratam da irracionalidade das massas, bem como aquelas que entendem que condições sociais determinam o comportamento dos atores do grupo. Para ele, o movimento social ocorre porque os atores estabelecem uma identidade coletiva, isto é, aquilo que une os indivíduos à medida que eles negociam, se comunicam, tomam decisões e reconhecem o que têm em comum. Portanto, não é algo dado, e a identidade coletiva depende de um sistema de ação, um processo de construção que engloba as emoções, intuições e criatividade dos atores. Todavia, ele não aborda as crises econômicas ou as contradições do sistema como variáveis a influenciar os movimentos sociais. A postura do indivíduo é o cerne da teoria:

\footnotetext{
186 ALONSO, Ângela. Op. cit., p. 63.

187 MELUCCI, Alberto. A invenção do presente: movimentos sociais nas sociedades complexas. Petrópolis, RJ: Vozes, 2001, p. 28.

188 MELUCCI, Alberto. Um objeto para os movimentos sociais. Lua Nova, São Paulo, n. 17, p. 57, jun. 1989.
} 
[...] ao emergir de ações concretas, contribuem fatores facilitadores de tipo conjuntural (como, por exemplo, a estrutura de oportunidades políticas, a existência de empreendedores, o grau de equilíbrio ou crise do ambiente, etc.). Mas esses fatores não poderiam operar se o ator não tivesse a capacidade de percebê-los e integrá-los em um sistema de orientação que constitui a estrutura condutora da sua ação. ${ }^{189}$

Depreende-se que, para Touraine, Habermas e Melucci, os movimentos sociais não se limitam a uma classe de trabalhadores. Eles se voltam para questões do cotidiano em prol da melhoria das condições de vida, da formação de estruturas democráticas e da afirmação e reconhecimento de novas identidades e valores e conseguem, com isso, explicar e compreender as demandas que surgem a partir da segunda metade do século XX. Outrossim, são movimentos dirigidos para a própria sociedade civil, em ações diretas, descentralizadas e sem uma hierarquia, tendo consciência de que as mudanças serão conquistadas a longo prazo.

É desde os anos de 1980 que se notam críticas às teorias acima e novas formulações sobre a relação da sociedade civil com o Estado.

A TNMS é criticada por tratar dos movimentos sociais de uma forma muito idealizada, como se eles representassem, em si, um sujeito revolucionário desvinculado da relação político-institucional. Além disso, essa teoria privilegia a busca de identidades e demandas simbólicas, sem valor material, como algo inovador. Aponta Plotke $^{190}$ que, no fundo, isso não é novo. As manifestações de décadas anteriores já tinham os mesmos anseios, porém, eles não tiveram destaque nos estudos da época, face ao enfoque economicista utilizado.

Esses Novos Movimentos Sociais formam um conjunto de expressões culturais, de identidades coletivas fluidas que parecem não ter ligação com ações políticas conduzidas em um determinado histórico, o que esvazia a teoria, porquanto a desloca de um processo político. A reflexão de Gohn é clara, nesse sentido:

A teoria do NMS usou o clássico binômio causa-efeito, sem entrar no mérito do conjunto de processos que configuram os movimentos como tais. Da política se extraiu a questão da ideologia, tomada como

189 MELUCCI, Alberto. Op. cit., 2001, p. 47.

190 PLOTKE, D. What's so new about new social movements? Socialist review, Londres, v. 20, n. 1, pp. 46-87, 1992. 
conjunto de representações que configuram uma visão de mundo; mas o caráter dessas representações coletivas, como parte de projetos políticos mais abrangentes, não foi tratado. Ou seja, são análises de conteúdo em que há recortes e certos aspectos da realidade que poderão não ter correspondência com formas empíricas num certo momento histórico. ${ }^{191}$

Em relação à Teoria de Mobilização de Recursos (TMR) e à Teoria do Processo Político (TPP), merece destaque a mencionada obra de Jean Cohen sobre os movimentos sociais contemporâneos. O autor critica a teoria da mobilização de recursos, por ser incapaz de explicar como se formam as identidades coletivas. A preocupação com a questão objetiva dos recursos financeiros necessários para a constituição do movimento deixa de elucidar a formação de nexo interno necessário à ação coletiva. E a teoria do processo político, de outro lado, é falha, por não abordar o aspecto cultural dos movimentos, adotando um recorte que coloca a sociedade política em relação de predominância sobre a sociedade civil. ${ }^{192}$

Ao longo dessas várias teorias verificadas nessas últimas décadas, percebe-se uma importância atribuída aos componentes psicológicos em confronto com os sociológicos, situação que se altera quando o papel dos agentes ganha relevo e se torna capaz de influenciar o sistema político como sujeito de poder. É com esse novo olhar que o cidadão se vê capaz de participar da tomada de decisão, apto a propor leis e projetos sobre a condução do Estado.

No Brasil, o avanço do processo de democratização multiplica os movimentos sociais. ${ }^{193}$ A atuação dos sindicatos ${ }^{194}$ e os movimentos populares foram importantes nesse processo de transição democrática e, durante a elaboração da Constituição de 1988, conseguiram se articular e apresentar suas reivindicações, muitas delas ouvidas e colocadas na Carta Magna. Depois disso, no decorrer da década de 90, marcada por orientações neoliberais que diminuíram o papel do Estado e flexibilizaram os direitos

\footnotetext{
191 GOHN, Maria da Glória. Teoria dos movimentos sociais. São Paulo: Loyola, 2004, p. 66.

192 COHEN, Jean. Op. cit., p. 682.

193 Pode-se afirmar que, desde a metade dos anos 1970, apareceram iniciativas de articulação mesmo em um clima de repressão política. A princípio eram iniciativas atomizadas, as quais lutavam por conquistas parciais, mas, ao longo dos anos, foram se fortalecendo e ganhando expressão no cenário político nacional.

194 O movimento sindical aparece revitalizado na década de 1970, na região do ABC paulista, a qual concentra as indústrias automotivas e eletrônicas do país. Mobilizam-se em greves na busca da valorização do papel dos trabalhadores e na luta por direitos no local de trabalho.
} 
sociais, o papel dos movimentos sociais foi ainda mais significativo, inaugurando experiências de gestão estadual e municipal.

Importante lembrar que inúmeros outros segmentos, e não somente os movimentos sociais, atuam nesse enfrentamento com o Estado e no questionamento das estruturas de poder. Um expressivo exemplo é o papel desempenhado pelas organizações não-governamentais (ONGs) e por segmentos do terceiro setor, ${ }^{195}$ que, agindo como grupos organizados, promovem diversas formas de luta para conquista da cidadania. ${ }^{196}$ Os Conselhos Gestores, Conselhos Municipais e o Orçamento Participativo são mecanismos institucionalizados e criados pelo Estado para promover a participação da sociedade na discussão das políticas públicas. Apesar de terem atuação discreta, são iniciativas que estimulam a reflexão sobre a relação entre a sociedade civil e o Estado.

Com efeito, a dualidade entre sociedade civil e Estado esteve sempre presente no caso brasileiro; faz parte da lógica da ação política, caracterizada pela inexistência histórica de um espaço comunicativo. No Brasil - e talvez em toda a América Latina -, as mediações sociais foram em grande parte conduzidas pelos meios de comunicação de massas. E os novos atores sociais que surgiram nessa transição para a democracia, ${ }^{197}$ como as ONGs, associações de bairro etc., ainda revelam dificuldades em se desvencilhar do jogo político comandado pelas elites democráticas, o que lança dúvidas sobre a real eficácia desses espaços institucionais.

195 Embora, a rigor, todos possuam suas definições próprias, muitas vezes as distinções são difíceis de serem estabelecidas. Alguns movimentos sociais adquirem um caráter mais institucional, como representantes ou mediadores de certos interesses. Por isso, a dificuldade do conceito. Aqui, tratamos todos eles como estruturas legítimas, com base na sociedade civil e, na sua maioria, nãoinstitucionais.

196 "Pode-se deduzir que, enquanto a cidadania atua na esfera estatal, a sociedade civil atua na esfera pública, onde associações e organizações se engajam em debates, criam grupos e pressionam em direção a demandas a determinadas opções políticas, produzindo, consequentemente, estruturas institucionais que favoreçam a cidadania.” KUNSCH, Margarida M. K. Organizações, cidadania, comunicação e os limites entre as estratégias e a ética. In: MOREIRA, Sônia Virgínia. Mídia, ética e sociedade. Belo Horizonte: PUC Minas/INTERCOM, 2004, p. 100.

197 Transição marcada pela campanha das “diretas já”, que poderia ter criado um vínculo entre a sociedade civil e a sociedade política, contudo, ao contrário, provocou uma ruptura ainda maior entre as duas, já que o próprio movimento pelas “diretas” não conseguiu romper com o patrimonialismo nem provocou mudanças na cultura política do país, marcada pela corrupção, por exigências clientelistas e negócios escusos. Por outro lado, a última década do século XXI reflete um novo consenso sobre a necessidade de transparência, prestação de contas e a necessidade da lei para punir ações criminosas. 
Além disso, muitos desses espaços são criados por lei, espalhando-se pelo país sem muita fiscalização ou orientação. Em muitos desses conselhos, não são tomadas decisões significativas e tampouco são discutidas questões orçamentárias. Embora sejam espaços de atuação das entidades civis, ainda não conseguem agregar as demandas da sociedade civil. Deveriam ser espaços destinados à partilha real do poder e tornam-se apenas mais um espaço de descrédito do cidadão.

A democracia reside na vontade dos cidadãos de agirem, de maneira responsável, na vida pública. O espírito democrático forma uma consciência coletiva que estimula iniciativas da sociedade civil incorporadas nas ações dos movimentos sociais para promover direitos e a cidadania. As instituições não podem prescindir de uma comunicação viva e permanente, que agregue valores e facilite os processos interativos e organizacionais com seus diferentes públicos, com a opinião pública e com a sociedade em geral, sempre sob o comando da moral e da ética. E gradualmente o Estado passa a ver esses movimentos e arranjos sociais como parceiros estratégicos e necessários para a melhor atuação das instituições no âmbito de uma governança democrática, principalmente quando se está diante de uma série de transformações no cenário político internacional e da globalização, pois delas decorrem novas demandas e questionamentos, exigindo uma cooperação ainda maior entre Estado e sociedade civil.

Manuel Castells faz significativa abordagem do conceito de sociedade em rede, tema de seus estudos desde a década de 1990. O autor relaciona o conceito de redes com a globalização e as questões econômicas contemporâneas que surgem com o fim do socialismo, a reestruturação do capitalismo, o enfraquecimento dos movimentos dos trabalhadores, a interação global dos mercados financeiros e o advento das tecnologias de informação, que se caracterizam por uma linguagem digital universal e sem barreiras.

É um mundo que passa por profundas mudanças. Indivíduos que antes se encontravam dispersos ou em isolamento agora podem encontrar uma causa em comum apenas empregando ferramentas tecnológicas. São formadas redes internacionais que defendem as mais diferentes causas, ampliando o alcance das ações sociais e desenvolvendo estratégias mais eficazes de defesa de seus interesses. 
Essa possibilidade de comunicação rápida e barata possui relevância não só globalmente, mas também localmente. As redes de movimentos sociais são marcadas por uma organização horizontal, que propicia simples circulação de informação e articulação entre seus membros. Nascem e se desenvolvem na sociedade civil e apresentam novas demandas sociais. Não conhecem barreiras de integração, passando a conhecer e integrar outros movimentos sociais que ampliam a força da rede. ${ }^{198}$ Representam, assim, um espaço público surpreendente, o qual possibilita várias interações políticas e sociais, formam alianças entre grupos locais e podem adquirir dimensão internacional.

Scherer-Warren frisa que as redes são formas de organização pautadas pelo desejo e transformação da realidade social, e nas quais as práticas de solidariedade, reciprocidade e compartilhamento de ações são potencializadas pelas tecnologias de informação, sobretudo pela Internet.

Além da atividade associativa, da facilidade organizacional e economicamente compensadora, e de sua dinâmica informal, as redes possuem a capacidade de mobilizar um grande número de cidadãos, além de estimularem a "inteligência coletiva”, que valoriza o pertencimento e o envolvimento em projetos coletivos.

Lévy define inteligência coletiva como sendo aquela “[...] distribuída por toda parte, incessantemente valorizada, coordenada em tempo real, que resulta em uma mobilização efetiva das competências”. ${ }^{199}$ Para haver mobilização das competências, o mesmo autor afirma que elas precisam ser identificadas e reconhecidas em sua diversidade. Com isso, os movimentos sociais de outrora são revigorados, pois o espaço público virtual aprimora a valorização e inclusão do outro e cria um ambiente de mobilização do pensamento coletivo direcionado para governar ou apresentar propostas de governo para a cidade, o estado, o país. Com isso, a relação entre sociedade civil e

198 Scherer-Warren ressalta esses aspectos da resistência contra a dominação e da produção de novas identidades como relevantes desdobramentos trazidos pelas comunicações virtuais. SCHERERWARREN, Ilse. Movimentos sociais e educação na era da informação. Revista de Educação Pública, Cuiabá, v. 19, p. 139-145, 2002.

199 LÉVY, Pierre. A inteligência coletiva: por uma antropologia do ciberespaço. Trad. Luiz Paulo Rouanet. 5. ed. São Paulo: Loyola, 2007, p. 28. 
Estado ganha um novo sentido, mais democrático e mais capacitado a traduzir o pensamento plural.

As manifestações de junho e julho de $2013^{200}$ surpreenderam, porque quebraram o paradigma sempre presente em vários discursos de que a população é apática, desinteressada pela coisa pública e desmobilizada. ${ }^{201}$ Fato foi que políticos e partidos estavam atônitos, desconcertados e sem saber como lidar com a situação. As palavras de Falcão resumem o momento:

No fundo, os partidos têm uma relação de amor e ódio com as organizações sociais. Dependem delas, como viveiros que são dos eleitores. Mas temem a concorrência. Esta ambiguidade acaba por paralisá-los. Nem apoiam, nem criticam. Ausentam-se. Foi o que aconteceu. ${ }^{202}$

O grande historiador Sérgio Buarque de Hollanda tratou do brasileiro cordial, uma herança deixada pelo mundo ibérico, marcada pela inaptidão do brasileiro para construir uma ordem pública, e pela condição de conformidade com as regras que reafirmam a pessoalidade na relação entre sociedade e Estado. ${ }^{203}$

Foi Gilberto Freyre, contudo, com sua análise cultural, que conseguiu explicar como essa sociedade escravocrata é conformista. Em Casa Grande e Senzala, ${ }^{204} \mathrm{um}$ marco interpretativo sobre a história da educação e da cultura do país, o autor apresenta

200 Movimentos que tomaram de assalto o país e representaram um fato político novo na sociedade brasileira, pois surgiram de uma reclamação pontual sobre o aumento da tarifa do transporte público e transcenderam essa demanda, atingindo as instituições da democracia representativa e deixando evidente que os cidadãos não se sentem bem representados por aqueles que elegeram. Um alerta aos políticos, os quais também não sabem como interpretar essas manifestações.

201 Há mobilizações em curso; talvez não estejam ocorrendo na velocidade requerida ou com a organização necessária, mas há iniciativas em movimento. No Brasil, os abaixo-assinados virtuais se popularizaram e traduzem a indignação popular, influenciam a cobertura da imprensa e elaboram projetos de lei, como a Lei Ficha Limpa. Cinco meses depois de ser lançada no Brasil, por exemplo, a CHANGE, plataforma de petições online, presente em 196 países, conquistou mais de 525 mil usuários brasileiros, entre ONGs e pessoas físicas. A tecnologia permite a mobilização, um despertar do cidadão, mesmo que de forma superficial; entretanto, ainda é necessário aprimorar o debate e as reflexões sobre os projetos sociais.

202 FALCÃO, Joaquim. Democracia, direito e terceiro setor. Rio de Janeiro: Editora FGV, 2004, p. 41.

203 No Brasil, teríamos "[...] certa incapacidade, que se diria congênita, de fazer prevalecer qualquer forma de ordenação impessoal e mecânica sobre as relações de caráter orgânico e comunal, como o são as que se fundam no parentesco, na vizinhança e na amizade." HOLLANDA, Sérgio Buarque de. Raízes do Brasil. São Paulo: Companhia das Letras, 1995, p. 137.

204 FREYRE, Gilberto. Casa grande \& senzala: formação da família brasileira sob o regime de economia patriarcal. Rio de Janeiro: Maia \& Schmidt, 1953. 
as peculiaridades da formação brasileira, conduzida por uma ideologia que tende a apagar as diferenças, com um sentimento de inconformismo que integra os contrários, estabelecendo uma comunicação recíproca entre diferentes.

Essas análises praticamente indiscutíveis, pela sua incontestável contribuição e inteligência, todavia, não reconhecem qualquer traço de racionalidade trazido pelo pensamento moderno, o que dificulta explicações sobre esses movimentos sociais. Em entrevista na Folha de S. Paulo, o sociólogo Francisco de Oliveira afirmou que esses movimentos, que “[...] assustaram os donos do poder”, foram significativos para provar uma mudança nesse paradigma da sociedade brasileira pacata, constituída por “[...] um conformismo que só explode em violência privada”. ${ }^{205}$ As revoltas de junho levaram uma multidão de aspirações e frustrações para as ruas e, apesar das reivindicações fluidas, elas conseguiram provocar uma polarização política, sinal de amadurecimento da sociedade. O sistema político está em descompasso com o grau de democracia brasileiro e precisa ser provocado e modificado para se adequar, principalmente, ao diálogo proposto pelos novos participantes desse movimento: a juventude brasileira.

Cumpre lembrar que, não obstante os poucos ganhos concretos obtidos, o relevante foi ter havido o despertar da população, o que só foi possível pela força e dinamismo das mídias sociais. A revolução, no fundo, é sempre a mesma, porque os ideais de igualdade e liberdade não mudam. Tocqueville apontava as mesmas questões no momento que precedia a grande Revolução Francesa. Importante é haver a ruptura, mesmo que gerada por ideais e ilusões que sempre se repetem; importante é levar os jovens às ruas em busca de uma transformação radical, que nunca é completa, mas precisa ser iniciada em algum momento. ${ }^{206}$

205 Íntegra disponível em: <http:// http://www1.folha.uol.com.br/poder/2013/11/1368697-assustarem-osdonos-do-poder-e-isso-foi-otimo-diz-o-sociologo-chico-de-oliveira.shtml>. Acesso em: 09 nov. 2013.

206 “Eu não achava que a jornada de 22 fosse capaz de produzir inquietações sérias. A multidão já enchia as ruas, mas parecia composta de curiosos e descontentes, mais do que sediciosos: o soldado e o burguês trocavam cumprimentos ao se encontrar e, entre a multidão, eu ouvia menos gritos que gracejos. Sei que não se deve confiar nessas aparências. São os moleques de Paris que costumam empreender insurreições, e em geral alegremente, como escolares que saem em férias.” O cenário das revoltas em muito se assemelha, seja no século XVIII, seja no XXI, e elas ocorrem porque atingem o ponto de saturação e a sociedade clama por uma mudança, recobrando os valores democráticos do poder nas mãos do povo. Apesar de seu viés negativo, com pontos de violência e uma abordagem depreciativa de setores da mídia, o resultado final nunca é nulo, porque, ainda que com poucas conquistas, ou até mesmo com a derrota, a história nos mostra que o povo sempre volta a se reerguer 
É evidente que a espaço público virtual não é perfeito. Em seu interior também se desenvolvem relações de conflito e de poder, a partir do momento em que um ator ganha centralidade na rede e exerce influência sobre os demais atores, controlando os fluxos de informação e as escolhas na rede, o que precisa ser evitado.

Outro ponto negativo são os ataques digitais que acontecem na rede, com acessos desautorizados ao sistema on-line que, além de prejuízos contornáveis, podem causar sérios conflitos políticos.

Entretanto, o saldo é positivo. Além do exposto acima, as redes aprimoram a responsabilidade política e a prestação de contas (accountability), ambas primordiais em uma sociedade democrática.

A responsabilização das instituições sociais e dos indivíduos é a base dos governos representativos. A ausência desse procedimento pode levar a um longo período de instabilidade política, econômica e social. O termo inglês responsibility significa que o portador do mandato representativo possui responsabilidade política independente, podendo adotar critérios com base em seu juízo próprio na consecução do interesse público. O representante não representa apenas interesses segmentados daqueles que nele votaram, mas o interesse público. Tem o dever de lealdade, mas não pode se deixar controlar por interesses corporativos.

Ao contrário, o termo accountability compreende a prestação de contas e, nesse caso, o representante pode ser efetivamente responsabilizado pelos eleitores, em virtude de seus atos. O julgamento do eleitorado é retrospectivo, podendo reeleger ou não o representante ou governo em função de suas decisões. Não eleger é, nitidamente, uma sanção, que configura responsabilização.

O tema da accountability é aprofundado por O’Donnell, ${ }^{207}$ que focaliza suas duas formas: vertical e horizontal. A primeira é uma relação entre partes desiguais, na

para fazer valer sua causa. Cf. TOCQUEVILLE, Alexis de. Lembranças de 1848: as jornadas revolucionárias em Paris. Trad. Modesto Florenzano. São Paulo: Companhia das Letras, 2011, p. 66. 
qual os cidadãos exercem controle sobre as ações do governo, valendo-se, sobretudo, do processo eleitoral. Já a accountability horizontal envolve partes hierarquicamente iguais em uma relação, com a inclusão de mecanismos de controle e verificação (checks and balances).

Ora, no ambiente virtual, a prestação de contas torna-se mais transparente e pode ser avaliada e controlada quase que de forma instantânea. Esse é um ambiente que amplia a informação pública e aproxima os governantes dos cidadãos, em um espaço de produção e recepção de conteúdo direto o qual oferece ao governante a possibilidade de adequar sua gestão ao interesse coletivo e, ao governado, oferece a chance de se fazer ouvir. Falar em accountability na ágora virtual é ativar os laços de responsabilização do Estado e estimular a vigilância sobre a res publica.

Além disso, as redes são estruturas dinâmicas que causam impacto e repercussão imediatos, articulando grupos de manifestantes que podem estar dispersos geograficamente, mas que estão unidos em ideologias compartilhadas.

Por tudo isso é que a Internet é cada vez mais uma ferramenta fundamental para a participação política e o engajamento nas lutas sociais. As manifestações que ocupam as redes criam movimentos sociais diversificados e que podem ser articulados em larga escala, incentivando o agir do cidadão e introduzindo novas formas de se fazer política. Vários atores sociais surgem e se conectam, sentindo-se capazes de desencadear mudanças. Nota-se que, apesar das várias formulações novidadeiras, na grande maioria, são os clássicos e prestigiados valores universais os que acabam sendo defendidos, como os direitos humanos, a liberdade de expressão, a preservação ambiental, a tolerância, o respeito, dentre outros. Essa forma de agir ainda está em processo de construção. Há muitas transformações pela frente que precisam ser

que concorre com a obrigação de prestar contas (accountability), mas também a própria obrigação de prestar contas co-existe com outros termos - por exemplo, respondibilidade (answerability), ou com outras dimensões mais concludentes - a obrigação de suportar as consequências legais dos seus actos (liability).” LOMBA, Pedro. Teoria da responsabilidade política. Coimbra: Coimbra Editora, 2008, p. 82. E também a tese de doutoramento defendida por Bruno C. Lorencini, na Universidade de São Paulo, intitulada A responsabilidade do poder político no Estado constitucional sob o paradigma da “democratic responsiveness”, 2013. LORENCINI, Bruno C. A responsabilidade do poder político no Estado constitucional sob o paradigma da “democratic responsiveness”. 2013. Tese (Doutorado em Direito) - Universidade de São Paulo, São Paulo, 2013. 
estimuladas e assimiladas, contribuindo para a formação e a manutenção da cidadania contemporânea.

\subsubsection{Liberdade de expressão e manifestação}

O aprofundamento da democracia e o fortalecimento da cidadania por meio das novas possibilidades virtuais só são possíveis se estiver presente a liberdade, elemento fundamental do Estado Democrático de Direito, mais especificamente a liberdade de expressão e de manifestação.

O constitucionalismo moderno surge no século XVIII, fruto das Revoluções Francesa e Americana. Cumpre mostrar a lição de Dippel:

[...] a importância singular da Declaração dos Direitos de Virgínia de 1776 reside no facto de ter estabelecido o catálogo completo dos traços essenciais do constitucionalismo moderno, características cuja natureza constitutiva é hoje tão válida quanto há cem anos atrás: soberania popular, princípios universais, direitos humanos, governo representativo, a constituição como direito supremo, separação dos poderes, governo limitado, responsabilidade e sindicabilidade do governo, imparcialidade e independência dos tribunais, o reconhecimento do povo do direito de reformar o seu próprio governo e do poder de revisão da Constituição. ${ }^{208}$

Liberdade, democracia e constitucionalismo são temas interligados e complexos. A liberdade é um dos pilares da democracia, que significa, por sua vez, o poder do povo, o qual possui a capacidade de condução das questões politicamente relevantes de sua comunidade, inclusive o próprio conteúdo da Constituição.

Ensina o mestre Ferreira Filho que o constitucionalismo é o movimento político e jurídico que institui regimes constitucionais, ou seja, “[...] governos moderados, limitados em seu poder, submetidos a Constituições escritas.”209 Dentre os requisitos para a instauração de um regime constitucional, relaciona o autor a necessidade de haver um poder estabelecido, uma opinião pública ativa e um certo nível de desenvolvimento socioeconômico e cultural do povo.

208 DIPPEL, Horst. História do constitucionalismo moderno. Trad. Antônio M. Hespanha e Cristina N. da Silva. Lisboa: Fundação Calouste Gulbenkian, 2007, p. 10.

209 FERREIRA FILHO, Manoel Gonçalves. Curso de direito constitucional. 36. ed. São Paulo: Saraiva, 2010, p. 33-34. 
O constitucionalismo, pois, implica limitação de poder, que, em última instância, é o poder do povo, quando se observa um ambiente democrático. Surge aqui uma tensão entre poder constituído e poder constituinte, entre democracia e constitucionalismo, mas uma tensão que leva à própria manutenção da constituição. Ora, se é o povo soberano que cria as leis de sua comunidade política e que fixa uma ordem normativa, então o povo pode exigir que essa ordem seja respeitada por todos. $\mathrm{O}$ povo soberano torna-se, assim, o povo unido em torno de um Estado, capaz de propor as leis que regem o grupo. E, mais uma vez, a anotação de Ferreira Filho se impõe:

O reconhecimento de que o povo é o titular do poder constituinte pouco esclarece quanto ao exercício deste mesmo poder. Quer dizer, o povo pode ser reconhecido como titular do poder constituinte, mas não é jamais quem o exerce. Ele é titular passivo ao qual se imputa uma vontade constituinte sempre manifestada por uma elite. ${ }^{210}$

O poder constituinte atua de forma permanente. Para Müller, entretanto, esse seria um poder real apenas se os poderes constituídos fossem efetivamente exercidos pelo próprio poder constituinte. A queixa de Müller é no sentido de ver o povo ser invocado nos documentos constitucionais, mas pouco ser dito sobre o seu poder:

[...] vem à mente também a fórmula do "government of, by, and for the people”, cuja nitidez distintiva contudo não tem muito alcance. Especialmente incerto é aqui aquele "of" the people, que deveria, dependendo da práxis normativa, ser ainda resgatado, como grandeza de atribuição "nos bastidores" da ação do Estado ou ser banido do discurso democrático na sua versão icônica. ${ }^{211}$

Há muitas abordagens e estudos sobre o tema do poder constituinte. Sièyes, por exemplo, na clássica obra $O$ que o terceiro Estado?, ${ }^{212}$ compreendia a Constituição como um documento de supremacia indiscutível, obra do poder constituinte, a que se submetiam os poderes constituídos. O cerne de sua teoria está na ideia de que o poder pertence à Nação, que é a própria lei, soberana e determinada pela razão.

210 FERREIRA FILHO, Manoel Gonçalves. O poder constituinte. 5. ed. São Paulo: Saraiva, 2007, p. 31.

211 MÜLLER, Friedrich. Quem é o povo: a questão fundamental da democracia. Trad. Peter Naumann. 4. ed. São Paulo: Revisa dos Tribunais, 2009, p. 69.

212 SIEYÈS, Emmanuel J. Que é o Terceiro Estado? Trad. Norma Azeredo. São Paulo: Líber Juris, 1988. Sua tese sobre a supremacia da Constituição deu argumentos para o controle de constitucionalidade das leis, tendo servido de premissa para que o juiz Marshall, da Suprema Corte norte-americana, no caso Marbury x Madison, defendesse o controle de constitucionalidade feito por tribunais e por juízes monocráticos, isso no ano de 1803. 
Se, na Idade Média, o poder era fruto da expressão divina e o monarca reinava absoluto, na Revolução Francesa, o Poder Constituinte pertencia à nação ou ao povo burguês e, mais tarde, nas revoluções russas, esse poder estava com o proletariado.

Maurice Hauriou, sem muito se afastar da teoria de Sieyès, enxerga a nação como titular do o Poder Constituinte, bem como de todos os demais poderes constituídos. Conforme o autor, existe a superlegalidade ${ }^{213}$ constitucional, que é maior do que a própria constituição escrita, por isso, pode criar e modificar essa constituição.

A construção kelseniana ${ }^{214}$ identifica Estado e Direito, hierarquiza as normas jurídicas e permite que toda a atividade estatal seja limitada pelo Direito. A Constituição é a norma fundamental dessa estrutura e a eficácia das leis é condição de validade da ordem jurídica.

Insta sublinhar a obra de Carl Schmitt, ${ }^{215}$ para quem a Constituição é fruto de uma decisão política fundamental, da qual emana a validade de todo o ordenamento. Essa vontade política é representada, em uma democracia, pelo povo. A Constituição é, por conseguinte, fruto do povo, fruto desse ser político que está acima e além da própria constituição, e não de uma norma válida ou eficaz. ${ }^{216} \mathrm{O}$ poder constituinte é superior e engloba os demais poderes, sendo o único capaz de resolver todos os conflitos, lacunas ou questões concernentes à decisão política fundamental.

Nestes breves comentários sobre contribuições tão expressivas, deseja-se concluir que os conceitos de Constituição e Poder Constituinte são inseparáveis e que o ideal seria diminuir a tensão a envolvê-los, reforçando a noção de que, no direito constitucional moderno, o sujeito do poder constituinte é o povo, e a democracia não

213 HAURIOU, Maurice. Principes de droit publique. 2. ed. Paris: Recueil Sirey, 1916, p. 678. "Il nous reste à parler de la loi constitutionnelle considérée comme une loi spéciale supérieure aux lois ordinaires et de sa souveraineté en tant qu'elle entraîne la limitation de la souveraineté du gouvernement, particulièrement du pouvoir légilslatif.”

214 KELSEN, Hans. Teoria geral do direito e do estado. Trad. Luís Carlos Borges. São Paulo: Martins Fontes, 2000.

215 SCHMITT, Carl. Teoría de la constitución. Madrid: Alianza, 1982.

216 “É especialmente inexato caracterizar como Poder Constituinte, ou pouvoir constituant, a faculdade atribuída e regulada sobre a base de uma lei constitucional de mudar, i.e., de revisar determinações legais constitucionais.” Pinto Ferreira ao se referir à não aceitação de um poder derivado por Schmitt. In: PINTO FERREIRA. Princípios gerais de direito constitucional moderno. $1^{0}$ vol. São Paulo: Revista dos Tribunais, 1971, p. 50. 
precisa se opor ao constitucionalismo concebido como poder constituído. O poder constituinte é soberano e deve buscar a valorização da igualdade ${ }^{217}$ e da liberdade, por meio de instrumentos que permitam maior atuação do povo e possibilitem decisões coletivas. Devem ser ampliados os mecanismos de acesso ao processo de decisão, que atinjam a construção de um espaço comum, caracterizado pela implicação de todos os cidadãos no sistema de decisões políticas. Nesse sentido, a democracia eletrônica ganha relevo, porquanto capaz de rearticular povo, constitucionalismo e democracia, em um processo político inclusivo, que revigora as instituições democráticas e amplia os canais de manifestação, expressão e participação.

A liberdade de expressão é garantida pela Declaração Universal de Direitos Humanos, que, em seu artigo XIX, assegura a todo ser humano “[...] direito à liberdade de opinião e expressão, sem interferências, direito de ter opiniões e de procurar, receber e transmitir informações e ideias por quaisquer meios e independentemente de fronteiras."218

A noção de Constituição, nesse documento solene, que protege um conjunto de direitos e garantias e estabelece a organização e funcionamento do Estado, se vincula, indissociavelmente, à noção de liberdade e liberdades. A Constituição brasileira de 1988, que, como não poderia deixar de ser, segue essa mesma configuração, previu a proteção à liberdade de expressão. O legislador assegurou a livre manifestação do pensamento, sendo vedado o anonimato (art. $5^{\circ}$, IV) e garantiu igualmente a liberdade de expressão da atividade intelectual, artística, científica e de comunicação, independentemente de censura ou licença (art. 5º IX). O direito ao acesso à informação está previsto no inciso XIV do art. $5^{\circ}$ e, ainda, o inciso VI do mesmo artigo aborda a liberdade religiosa.

Seguindo a mesma orientação adotada pela Declaração Universal dos Direitos Humanos, o texto constitucional tratou da dupla acepção da liberdade de expressão: um

\footnotetext{
217 Não se trata aqui de uma visão liberal de igualdade, que torna os cidadãos de Rousseau iguais em face do contrato social, ou iguais membros de uma Nação, como pretendia Sieyès. Pleiteia-se a igualdade jurídica, que compõe a cidadania e permite que todos se tornem titulares de direitos. Esse primeiro passo é necessário para a obtenção futura de uma igualdade ainda mais ampla.

218 Disponível em: <http://www.ohchr.org/EN/UDHR/Documents/UDHR_Translations/por.pdf>. Acesso em 11 jun. 2013.
} 
deles é poder expressar o pensamento; o outro é o direito das demais pessoas de ter acesso à manifestação de outrem.

No capítulo sobre “Comunicação Social” da Constituição, o legislador volta a tratar dessas liberdades, referindo-se às manifestações emitidas por órgãos da imprensa e outros meios de comunicação. Assim, o art. 220, caput, assegura a liberdade de manifestação do pensamento, da criação, da expressão e informação, sob qualquer forma e veículo, enquanto o art. 220,§ $1^{\circ}$ protege a liberdade de informação jornalística.

No entender do Supremo Tribunal Federal, a liberdade de expressão engloba a livre manifestação do pensamento, as críticas e a possibilidade de exposição de fatos históricos. No Habeas Corpus 83.125-7, de relatoria do Min. Marco Aurélio, em que se argui a publicação de um livro sobre a ditadura militar, por ser considerado ofensivo ao Exército, o ministro relator afirmou não haver Estado Democrático de Direito sem a observância da liberdade de expressão, destacando o parecer da Procuradoria Geral da República:

[...] seria verdadeiramente aberrante tachar de inverdade uma tela tão triste de nossa história recente como a da repressão e da tortura, nem se podendo, em nome da proteção da honra e da intimidade, restringir a livre manifestação do pensamento quando se trata da discussão e crítica de arbitrariedades patrocinadas ou consentidas pelo Poder Público. ${ }^{219}$

Nesses termos, afirma-se que a liberdade de expressão é um direito fundamental $^{220}$ do indivíduo, pelo qual ele pode externar seus pensamentos, opiniões e conflitos sobre os mais variados temas, sendo fundamental para que a sociedade encontre, desse modo, a adequação entre mudança e estabilidade, entre contestação e consenso. Engloba a possibilidade de apresentar críticas e discordâncias, sinalizando que o ambiente é democrático e pluralista.

219 BRASIL, STF, HC 83.125, Rel. Min. Marco Aurélio, julgamento em 16 set. 2003, Primeira Turma, DJ de 7 nov. 2003.

220 De acordo com Jorge Miranda, os direitos fundamentais são “[...] os direitos ou as posições jurídicas subjectivas das pessoas enquanto tais, individual ou constitucionalmente consideradas, assentes na Constituição.” MIRANDA, Jorge. Manual de direito constitucional. Tomo IV, 2. ed. Coimbra: Coimbra Editora, 1998, p. 07. 
A liberdade de expressão é uma manifestação individual ou coletiva. Por isso é que ONGs, sindicatos, partidos políticos, dentre tantas outras instituições representativas de classes ou grupos de pessoas, têm condições de expor suas escolhas, podendo inclusive exercer pressão social por mudanças, como ocorre no caso dos movimentos sociais.

A liberdade de expressão é um elemento estruturante da ordem democrática constitucional, uma vez que autoriza a oposição ao governo, a disseminação de ideias plurais, a atuação livre da imprensa e a troca de informações, quem garante a vigilância e preservação dos direitos fundamentais e da própria democracia. Sem liberdade de expressão não seria possível haver democracia representativa.

A diferença entre a liberdade de opinião e a de expressão pode ser assim colocada:

[...] enquanto opinião diz respeito a um juízo conceitual, uma afirmação do pensamento, a expressão consiste na sublimação da forma das sensações humanas, ou seja, na situação em que o indivíduo manifesta seu sentimento ou sua criatividade, independente da formulação de convicções, juízos de valor e conceitos. ${ }^{221}$

O direito não opera em termos absolutos; há a constante necessidade de imposição de limites. Os direitos fundamentais são interdependentes e se fortalecem reciprocamente, todavia, devem atender aos limites traçados pela Constituição, sendo feito um balizamento entre os direitos fundamentais, a fim de que seja preservado o equilíbrio entre eles. Para tanto, aplica-se o princípio da proporcionalidade e da ponderação com outros direitos.

A imposição de limites e uma interpretação cuidadosa dos princípios constitucionais da liberdade de manifestação e de expressão, em conjunto com a inviolabilidade à honra e à vida privada (art. $\left.5^{\circ}, \mathrm{X}, \mathrm{CF}\right)$ e a proteção da imagem $\left(\operatorname{art.~} 5^{\circ}\right.$, XXVII, a, CF), são cada vez mais importantes, devendo-se evitar a censura prévia, para a qual existe vedação constitucional (art. 220, § 2 , CF). A posição do STF sobre o tema pode ser singelamente identificada, quando ele afirma que “[...] não cabe ao Estado, por

221 ARAÚJO, Luiz Alberto David; NUNES JÚNIOR, Vidal Serrano. Curso de direito constitucional. 6. ed. São Paulo: Saraiva, 2002, p. 103. 
qualquer de seus órgãos, definir previamente o que pode ou o que não pode ser dito por indivíduos e jornalistas”, ${ }^{222}$ privilegiando a liberdade de expressão e ratificando o regime democrático erigido pela Lei Fundamental do Brasil, regime da plena e livre circulação de ideias.

Não obstante seu caráter de direito fundamental, o STF reconhece a fixação de limites:

Liberdade de expressão. Garantia constitucional que não se tem absoluta. Limites morais e jurídicos. O direito à livre expressão não pode abrigar, em sua abrangência, manifestações de conteúdo imoral que implicam ilicitude penal. As liberdade pública não são incondicionais, por isso devem ser exercidas de maneira harmônica, observados os limites definidos na própria Constituição Federal (CF, ARTIGO $5^{\circ}, \S 2^{\circ}$, primeira parte). O preceito fundamental da liberdade de expressão não consagra 'direito à incitação ao racismo', dado que um direito individual não pode constituir-se em salvaguarda de condutas ilícitas, como sucede com os delitos contra a honra. Prevalência dos princípios da dignidade da pessoa humana e da igualdade jurídica. ${ }^{223}$

Pode-se sustentar que a liberdade de expressão brasileira é, pois, responsável, e estriba sua admissão desde que dentro de limites explícitos, como o direito de resposta e a proibição ao anonimato, e limites implícitos, como se dá no julgado acima citado.

A lei eleitoral impõe regras rígidas de limitação à liberdade de expressão, durante o período eleitoral, sendo proibido falar tudo o que se pensa sobre políticos e parlamentares. Os candidatos, por sua vez, não podem expor, injuriar nem caluniar outros competidores em disputa pelo poder político. Essa limitação do direito de expressão ocorre em prol do interesse público. Como os atos e condutas daqueles que disputam um cargo público são de interesse de todos, a lei eleitoral prevê limites que objetivam evitar crimes contra a honra ou imagem, ou outros abusos e excessos infundados, os quais, dada a facilidade de serem difundidos, podem causar prejuízos irreversíveis ao candidato e influenciar a opinião pública.

222 ADI 4.451 - REF - MC, Rel. Min. Ayres Britto, julgamento em 2 set. 2010, Plenário, DJe de $1^{\circ}$ jul. 2011.

${ }^{223}$ BRASIL, STF, HC 82.424, Rel. p/ o ac. Min. Maurício Corrêa, julgamento em 17 set. 2003, Plenário, DJ de 19 mar. 2004. 
Necessário sublinhar que, se as discussões acontecem dentro de um limite razoável ao jogo político, elas serão aceitas, sem haver a incidência do estabelecido pelo Código Eleitoral, privilegiando-se a liberdade de manifestação e expressão. O espírito da lei é coibir a campanha negativa, mas é claro que críticas objetivas aos candidatos, às suas administrações ou programas, mesmo que às vezes não sejam tão polidas, são aceitas. Nas palavras de Coneglian:

Não constitui ofensa a simples crítica eleitoral, a crítica a programa de partido, à realização de ato, à atitude administrativa do ofendido. [...] O homem público, principalmente o que está no exercício do poder de administração, ou aquele que se submete ao crivo de uma eleição, fica sujeito a críticas mais exacerbadas e generalizadas. Muitas vezes, essa crítica é injusta, mas não chega a caracterizar injúria ou difamação. ${ }^{224}$

O advento das tecnologias de comunicação exerceu forte influência sobre a liberdade de expressão, franqueando o acesso de milhões de brasileiros a uma enorme quantidade de conteúdo à disposição na Internet, de sorte a facultar que a transmissão de sentimentos, problemas, soluções e notícias fosse feita diretamente pelos cidadãos.

Em 1997, surgem os blogs, que logo se tornam muito usados pelos brasileiros devido à sua facilidade de elaboração, edição e atualização. A grande maioria desses pequenos sites de estrutura simplificada se transforma em uma espécie de diário virtual e aborda temas cotidianos que envolvem a família, o trabalho e outros interesses de quem o escreve. ${ }^{225}$ Depois, ganhou evidência no meio profissional, junto a jornalistas, profissionais do marketing e da propaganda e aqueles responsáveis por fazer a gestão de redes sociais.

224 CONEGLIAN, Olivar. 2004, p. 219. Propaganda eleitoral - de acordo com o Código Eleitoral e com a Lei $n^{\circ}$ 9.504/97. 6. ed. Curitiba: Juruá Ed., 2004, p. 219. Exemplo de jurisprudência com essa orientação é a do juiz eleitoral Oswaldo Horn: "Se crítica houve, não excedeu aos limites legais, tampouco denotou caráter ofensivo, até porque a Constituição Federal assegura a liberdade de expressão como consectário do estado democrático de direito.” BRASIL. TRESC. Acórdão $\mathrm{n}^{\circ}$ 19.250, 2004.

225 Os números impressionam. De acordo com o serviço de busca em blogs Technoratti, há 35,5 milhões de blogs e, a cada dia, são criados, em média, 75 mil blogs. Disponível em: <http://idgnow.uol.com.br/internet/2006/04/18/idgnoticia.2006-04-18.8581859551/>. Acesso em: 16 nov. 2012. 
No ano de 2004, surgiu o Facebook, um fenômeno da Internet, com um número impressionante de usuários no Brasil e no mundo. ${ }^{226}$ Dois anos mais tarde é criado o Twitter, um microblog que permite ao usuário enviar e receber mensagens de até 140 caracteres. A popularização da Internet e o grande uso das redes sociais elevou a disseminação da propaganda eleitoral negativa e dificultou enormemente o trabalho da Justiça Eleitoral e daqueles que militam na área, que precisam acompanhar o ritmo da Internet.

Com o intuito de definir balizas a comportamentos inaceitáveis nesse campo, a Lei n. 9.504/97, em seu art. 57-F, institui a responsabilização dos provedores de conteúdo, se comprovado seu prévio conhecimento. Já o artigo 53 proíbe censura prévia aos programas eleitorais gratuitos, mas veda a veiculação de propaganda que possa degradar ou ridicularizar o candidato.

A Internet agravou o problema da postagem e veiculação de informações anônimas. A Constituição Federal, em seu art. 5 , V, assegura o direito de resposta, também previsto pela lei eleitoral, conforme estabelece seu art. 58 (Lei nº 9.504/97):

Art. 58. A partir da escolha de candidatos em convenção, é assegurado o direito de resposta a candidato, partido ou coligação atingidos, ainda que de forma indireta, por conceito, imagem ou afirmação caluniosa difamatória, injuriosa ou sabidamente inverídica, difundidos por qualquer veículo de comunicação social.

Todavia, esse direito de reposta se apresenta ineficaz, no ambiente virtual. São inúmeros servidores localizados em diferentes partes do mundo, as informações são disseminadas de forma muito rápida, as comunidades virtuais possibilitam aos seus usuários a retransmissão das informações, de maneira que não se pode traçar o caminho percorrido por essa informação inverídica ou difamadora. Esse é um grave problema trazido pela rede e difícil de ser solucionado de forma satisfatória. Mais um desafio para a democracia.

226 De acordo com o site Olhar Digital, o Facebook Brasil possui 76 milhões de usuários ativos, sendo que 47 milhões navegam pelas suas páginas diariamente. Disponível em: <http://olhardigital.uol.com.br/noticia/37493/37493>. Acesso em: 10 out. 2013. 


\subsection{Representação política e sistemas eleitorais}

Durante os últimos duzentos e poucos anos, o desenho institucional da democracia tem sido praticamente o mesmo. "Foi a Revolução Francesa que consagrou o novo modelo democrático, o modelo da Democracia representativa." ${ }^{227}$ A inevitabilidade da representação, todavia, não a isenta de críticas e leva à elaboração de diversas teorias, com o intuito de aproximá-la do ideal democrático, na busca de conceitos mais justos e fidedignos, que aproximem o cidadão de parcela do poder.

Se representar é tornar presente alguma coisa que de fato não está, ${ }^{228}$ importante saber quem elege o representante. Nesse sentido, é oportuna a abordagem do conceito de cidadão e cidadania, para que ficasse definida a organização da sociedade, sua formação histórica, e como se dá o processo de ampliação da cidadania pelo voto. Entender o modo como é formado o corpo de representantes também é fundamental para a compreensão do modelo democrático. Por isso, a menção aos sistemas eleitorais.

A democracia brasileira não é caracterizada, apenas, pela vontade da maioria. É também uma democracia com mecanismos de participação semidireta, inclusiva, que adota o sistema eleitoral proporcional, que permite a participação das minorias, que preza o pluralismo político e dá condições para que opiniões dissonantes formem a vontade política.

Não que a democracia direta proposta em Atenas não tenha sido relevante. Muito pelo contrário. A democracia ateniense possui incontáveis méritos, que tentam ser resgatados até hoje, por vários autores de diversas nacionalidades. Apesar do pequeno número da população que efetivamente participava das discussões na ágora, ${ }^{229}$

227 FERREIRA FILHO, Manoel Gonçalves. Sete vezes democracia. São Paulo: Convívio, 1977, p. 45.

228 A obra clássica de Pitkin nos mostra que não há um conceito unívoco de representação. Ela parte da origem da palavra e interpreta seu significado em diferentes períodos históricos, seja no Iluminismo, passando pela representação formal, até a ideia da representação por confiança, que é tornar presente algo que não está, desenvolvida a partir das lições de Burke: "This introduces the idea of the professional or expert, and shifts the emphasis from mere substitution [...] toward trusteeship where the representative must be given a free hand to exercise his superior wisdom or skill.” PITKIN, Hannah Fenichel. The concept of representation. Berkeley: University of California Press, 1967, p. 135.

229 Ora, nessa época, ainda não havia a ideia de indivíduo que se opunha ao Estado, o que só surgiu na Idade Média. O que havia era autogoverno, decisões e leis obtidas com a participação de todos. O individualismo só aparece mais tarde, com São Tomás de Aquino, como afirma Villey. VILLEY, 
os gregos inventaram o valor democrático em si, o poder do povo, e seu modelo se orientava pelas premissas definidoras da democracia: igualdade, liberdade e respeito à lei.

Todavia, se o povo decidia soberanamente, ${ }^{230} \mathrm{o}$ dirigente político tinha que convencer a pólis, em cada reunião, da superioridade de suas propostas. Surgia aí a figura do demagogo, que tinha a função de influenciar a decisão dos cidadãos nos destinos do Estado. Ele despertava a paixão dos cidadãos por uma outra decisão, o interesse geral acabava ficando em posição secundária. A Guerra do Peloponeso, ${ }^{231}$ conflito que opôs Atenas e Esparta, representou o declínio da civilização grega e o fim da democracia ateniense.

Do século III a.C. ao século XVIII, a democracia não merece grande preocupação dos pensadores políticos, nem se traduz em experiências concretas. Não havia democracia em Roma, mas apenas um governo misto. ${ }^{232}$ E, na Idade Média, não houve democracia, mas apenas a formação de Repúblicas independentes.

No século XVIII, opera-se uma quebra cultural que altera paradigmas e influencia os dias de hoje. O homem passa a perceber-se centro da vida e do mundo e vê o triunfo do Iluminismo. A razão se torna a medida de todas as coisas e reconstrói o mundo, e o homem passa a ser tratado como indivíduo e não mais como elemento de

Michel. Filosofia do direito - definições de fins do direito. Os meios do direito. Trad. Márcia Valéria Martinez de Aguiar. São Paulo: Martins Fontes, 2003, p. 125-127.

230 Berlin, a despeito de não inaugurar o debate, empenhou-se em provar a superioridade da liberdade negativa, para ele, a única digna de reconhecimento: “[...] the notion of 'negative' liberty [...] however disastrous the consequences of its unbridled forms, has not historically been twisted by its theorists as often as or as effectively into anything so darkly metaphysical or socially sinistre or remote from its original meaning as its 'positive' counterpart.” BERLIN, Isaiah. Four essays on liberty. Oxford: Oxford University Press, 1969, p. XLVII.

231 Essa guerra durou de 431 a 404 a.C. Disponível em: <http://pt.wikipedia.org/wiki/Guerra_do_Peloponeso>. Acesso em: 8 set. 2013.

232 Como explica Bobbio, a Antiguidade Clássica nos brindou com Aristóteles e Platão, mas também com Políbio, que, além de apresentar sua teoria de formas de governo e classificar a democracia como umas das boas formas de governo popular, estabeleceu a necessidade de uma constituição, enfatizando: "Deve-se considerar a constituição de um povo como a causa primordial do êxito ou do insucesso de todas as ações.” BOBBIO, Norberto. As teorias das formas de governo. Trad. Sérgio Bath. 9. ed. Brasília: Editora UnB, 1997, p. 65. 
uma coletividade. ${ }^{233}$ Essa mudança de pensamento, como não poderia deixar de ser, atinge as instituições políticas que desembocam na democracia representativa.

O Iluminismo se opunha ao Absolutismo e se propunha retirar o poder das mãos do rei. É um projeto de emancipação humana que quer se contrapor ao poder estatal, legitimando o poder do homem sobre o homem (e, talvez, esse projeto iluminista ainda esteja em construção, ganhando fôlego com as teorias que revigoram a democracia e o agir humano). Dessa maneira, faz sentido ser esse um momento de transição de uma concepção antiga para uma moderna, no que se refere à forma democrática de governo.

Rousseau é um pensador crucial para fundamentar essa transformação. O idealizador da concepção moderna de democracia trabalhou as noções de vontade geral e soberania popular. A vontade geral se contrapõe ao fundamento quantitativo da vontade de todos, ou seja, é uma vontade que transcende as vontades particulares de cada um e que sugere que o cidadão possui uma vontade de interesse coletivo. Nesse momento, ele passa de indivíduo a cidadão.

A soberania, por seu turno, pertence a todos os membros que compõem a sociedade e é fundamentada na vontade geral, que é una, pura e incorruptível.

Assim, a pergunta que se deve propor na Assembleia do povo, por meio do voto, é se a lei está de acordo com a vontade geral. ${ }^{234}$

O importante desse contrato social elaborado por Rousseau é que dele decorre a ideia de legitimidade e unanimidade democráticas. O homem é livre e se une aos demais, não para perder a liberdade, mas para legitimá-la, pois somente os homens livres podem aceitar o poder de que ele tenha plena participação e no qual todos são governantes e governados.

Depois dele, Constant, em seu aclamado discurso "Da liberdade dos antigos comparada à dos modernos”, aponta que o governo representativo, que nasce com a

${ }^{233}$ Iluminismo é um projeto que parte da "[...] primazia da pessoa contra qualquer pretensão de colectividade”. In: GARY, J. O liberalismo. Trad. M. H. Costa Dias. Lisboa: Estampa, 1988, p. 12.

234 ROUSSEAU, J.J. Do contrato social. São Paulo: Martin Claret, 2000, p. 96. 
Revolução Francesa, precisa ser adotado, como símbolo de uma passagem sine qua non da concepção antiga para a moderna. Em suas palavras:

Daí vem, Senhores, a necessidade do sistema representativo, [...] uma procuração dada a um certo número de homens pela massa do povo que deseja ter seus interesses defendidos e não têm, no entanto, tempo para defendê-los sozinho. [...] os povos, para desfrutar da liberdade que lhes é útil, decorrem ao sistema representativo, devem exercer uma vigilância ativa e constante sobre seus representantes e reservarse o direito de [...] afastá-los, caso tenham traído suas promessas.[...] Eis por que, tendo em vista que a liberdade moderna difere da antiga. ${ }^{235}$

A essência da democracia está na sua titularidade: é um poder do povo, o soberano, que, no caso da democracia representativa, escolhe seus representantes para o exercício do governo. A democracia moderna é fruto do desenvolvimento da representação combinada com a igualdade proporcionada pela lei. Se todo o poder emana do povo e todos são livres e iguais em direito, todos deveriam ter as mesmas condições e o mesmo espaço de participação, mas isso não acontece, provocando uma contradição na articulação da ideia. A questão é abordada por John Stuart Mill, o primeiro a tratar do governo representativo, pelo qual o povo exerce o poder elegendo seus representantes em eleições periódicas. Para o filósofo, a democracia possui um valor ético: “[...] o maior mérito eu pode possuir uma forma de governo é o de promover a virtude e a inteligência do próprio povo.” ${ }^{236}$ Além disso, sua obra traz grande contribuição, ao valorizar a educação pública, que deve alcançar a todos os cidadãos, de todos os setores da sociedade:

[...] é através da discussão política, e da ação política coletiva, que um homem, cujos interesses são limitados por suas ocupações diárias a um círculo estreito, aprende a simpatizar com seus concidadãos e se torna um membro consciente da grande comunidade. ${ }^{237}$

Mill é também grande defensor da liberdade política e da liberdade individual, ${ }^{238}$ por entender que elas equilibram os efeitos que podem advir do progresso

235 CONSTANT, Benjamin. Da liberdade dos antigos comparada à dos modernos. Disponível em: $<$ http://caosmose.net/candido/unisinos/textos/benjamin.pdf>. Acesso em: 8 set. 2013.

236 MILL, John Stuart. Considerações sobre o governo representativo. Brasília: Editora da Universidade de Brasília, 1981, 19.

237 MILL, John Stuart. Op. cit., p. 19.

238 "That principle is, that the sole end for which mankind are warranted, individually or collectively, in interfering with the liberty of action of any of their number, is self-protection. That the only purpose 
e da civilização. A personalidade individual deve se desenvolver - por isso, até, a preocupação com a educação política - e realizar suas capacidades, defendendo-se das interferências hostis sobre sua autonomia.

O ambiente que melhores condições oferece para o desenvolvimento das faculdades humanas, da educação, da liberdade, seria a democracia representativa, pela qual os homens são formados para se organizar e buscar avanços em prol do bem comum, estimulando a participação política do maior número de cidadãos. ${ }^{239}$

Pode-se afirmar que a grande reivindicação desse momento era o sufrágio universal, a plena participação política, uma leitura inglesa da democracia, por isso, até mesmo, um inglês apresenta o termo democracia representativa, que evidencia a preocupação com a participação da maioria (e não da totalidade). A partir disso, a democracia representativa evolui e passa a ser vista como o melhor do modelos, no contexto da modernidade.

As críticas não tardam a surgir. O pensamento político socialista ${ }^{240}$ contesta o caráter democrático da representação e a adoção de um sistema eleitoral modelado pela razão burguesa. Só seria possível um governo de todos com a progressiva tomada de poder pelo proletariado, com a dissolução da propriedade privada e a rejeição aos valores burgueses.

Outra expressiva e sempre atual crítica (que será retomada na análise sobre os partidos políticos) é a formação de uma elite: ${ }^{241}$ a classe política. Os partidos acabam

for which power can be rightfully exercised over any member of a civilized community, against his will, is to prevent harm to others.” MILL, John S. On liberty. New Haven: Yale University Press, 2003, p. 80.

239 Mill demonstra preocupação equivalente à de Tocqueville sobre a possível emergência da ditadura da maioria, que precisa ser evitada, sendo garantida a voz das minorias. Idem, p. 94 e 117.

240 Os críticos dessa visão indagam: “[...] where the 'workers' come from; how they got to be workers; and why that is what they want to be. In the way same way, (male) socialists hardly ever discuss how the sexual division of labor constitutes itself.[...] Pseudo representation, party oligarchy, impervious bureaucracy, unresponsive planning, and male domination, are not a series of malign institutions that have been accidently tacked on, as it were, to the contemporary division of labor in industrial societies. They are rather the expression of that division of labor.” GREEN, Philip. Retrieving democracy in search of civic equality. New Jersey: Rowman \& Allanheld, 1985, p. 9.

241 Michels, Pareto e Mosca são os cientistas políticos que fundam a teoria das elites, existindo para eles somente duas classes: a que dirige e a que é dirigida. A "lei de bronze” da oligarquia de Michels percebe que o partido, ao ganhar força, concentra o poder nas mãos de uma minoria, provoca o 
sendo controlados por um pequeno grupo que quer manter a continuidade no poder e, para isso, criam uma oligarquia centralizadora, que se afasta da vontade real dos cidadãos, em um trajeto antidemocrático inerente à estrutura partidária. Decorre, dessa característica, a importância da democracia interna dos partidos.

Diante dessas perspectivas, é possível resgatar a democracia representativa? ${ }^{242}$

Kelsen introduz a democracia pelos partidos. Em sua visão procedimental da democracia, o autor enfatiza a necessária presença desses organismos como instrumentos de racionalização do poder. Ora, diante da pluralidade de interesses visíveis na sociedade, não de pode admitir que a vontade geral seja a manifestação de apenas um desses grupos de interesse. Aqueles contrários aos partidos são as “[...] forças políticas que visam ao domínio absoluto dos interesses de um só grupo.” ${ }^{243}$ Os partidos atuariam na conciliação entre esses interesses opostos, realizando acordos, "[...] a fim de que a vontade geral seja capaz mover-se ao longo de uma linha média." ${ }^{244} \mathrm{O}$ consenso resultante desses acordos equivale à vontade geral, democrática, superior aos partidos e aos interesses individuais. Desse modo, “[...] a democracia do Estado moderno é a democracia indireta, parlamentar, em que a vontade geral diretiva só é formada por uma maioria de eleitos pela maioria dos titulares dos direitos políticos.”245

Ao apresentar essa configuração, Kelsen influencia constituições e a lei eleitoral, pois se torna precursor da ideia de fidelidade partidária. $^{246}$

crescimento da burocracia partidária e o distanciamento dos dirigentes das vontades dos representados. Infelizmente, até hoje, essa é uma visão difícil de ser rebatida.

242 A democracia representativa é simbolizada pelo voto, meio de escolha dos representantes. Rousseau, em seu Contrato Social, já afirmara que o homem nasce livre, mas deixa de sê-lo a partir do momento em que escolhe seus representantes. Deve-se deixar de identificar democracia apenas com o momento eleitoral e o cidadão como sendo um mero eleitor: “L'esprit public est encore ce qu'on appelle le civisme, c`est-à-dire l'état d'esprit du citoyen conscient, et c'est ici qu'il faut se souvenir que le citoyen n'est pas l'electeur et que le civisme n'est pas l'electorat; l'electorat est une fonction de gouvernement, le civisme est une fonction de sujétion, l'électeur est un agent du gouvernement, le citoyen est un collaborateur libre du gouvernement. HAURIOU, Maurice. Principes de droit public. 2. ed. Paris: Recueil Sirey, 1916, p. 661.

243 KELSEN, Hans. A democracia. Trad. Ivone C. Benedetti. São Paulo: Martins Fontes, 1993, p. 41.

244 Ibidem.

245 KELSEN, Hans. Op. cit., p. 43.

246 Caggiano explica que a Constituição checoslovaca de 1920, de redação de Kelsen, já contém a vinculação do representante eleito ao seu partido, destacando que essa cláusula foi adotada pela 
A democracia está intrinsecamente ligada à presença dos partidos políticos, que, apesar das várias críticas - merecedoras - que recebem, ainda se apresentam como a essencial forma de intermediação entre representantes e representados. Nesses termos:

As funções partidárias se apresentam qualificadas e com a aparente insubstitutibilidade dos partidos políticos nas atividades do Estado moderno. Hoje, impera o que muitos estudiosos chamam de Sistema de Partidos.

Vive-se, pois, atualmente, o que os analistas denominam a Idade de Ouro dos partidos, em razão das importantes funções que assumiram estas agremiações na sociedade e nos assuntos de Estado. ${ }^{247}$

Maurice Duverger é o autor a capitanear a transformação essencial dos partidos, verificando neles um duplo papel na democracia. Em 1951, ao lançar a obra Les partis politiques, Duverger resgata os partidos da situação de desconfiança em que eles se encontravam, com a sombra da oligarquia a rondar os governos representativos e a depreciar o papel partidário. Desenvolve seu raciocínio afirmando que, mesmo havendo a estrutura oligárquica, os partidos de massa são capazes de conduzir o povo à pólis, pois a elite política a ser formada virá das camadas populares. Eles alcançam a classe dirigente em um movimento vertical de mobilidade política e social.

Além dos partidos de massa, existem ainda os partidos de quadro, que equivalem à representação política abstrata, pela qual os parlamentares têm a incumbência de fazer as leis e as políticas de governo, sem demonstrar vínculos entre povo e elite.

Com esse desenho, a democracia representativa ficou mais complexa, exigindo disciplina e sistemas partidários que realmente espelhassem os diversos interesses de classe. Ao mesmo tempo, a formulação dos partidos de massa favoreceu uma conciliação viável e otimista entre as elites e a representação dos diversos interesses sociais. Nas palavras do mestre francês:

Constituição portuguesa de 1982/RC 1997, que, em seu art. 160, trata de perda de mandato para aquele deputado que se inscrever em partido diverso daquele pelo qual foi eleito. CAGGIANO, Monica Herman S. A fenomenologia dos trânsfugas no cenário político-eleitoral brasileiro. In: CAGGIANO, Monica Herman S. (Org.). O voto nas Américas. São Paulo: CEPES, 2008, p. 229.

247 LEMBO, Cláudio. Participação política e assistência simples no direito eleitoral. Rio de Janeiro: Forense Universitária, 1991, p. 62-63. 
Um sistema [de partidos] permite ao mesmo tempo a constituição de uma classe dirigente oriunda do povo, que substitui as classes antigas. Em relação a este último ponto, partido único e regimes pluralistas se aproximam. A significação mais profunda dos partidos políticos é que eles promovem a criação de novas elites, que restituem o verdadeiro sentido da representação, o único sentido real. Todo governo é oligárquico por natureza: mas a origem das oligarquias e sua formação podem ser muito diferentes, e é isso que determina sua ação. É preciso substituir a fórmula governo do povo para o povo pela seguinte: governo do povo por uma elite oriunda do povo. ${ }^{248}$

Em decorrência, a democracia representativa não apenas é compatível com os partidos de massa, como só consegue ser operacionalizada por eles.

Suas premissas também são fundamentais para determinar a influência do sistema eleitoral sobre o sistema partidário. ${ }^{249}$

Exsurge uma nova vertente democrática, denominada participativa, que valoriza os instrumentos do referendo, plebiscito, iniciativa popular, assim como as audiências públicas e outras formas que propiciem um debate democrático mais amplo, privilegiando a qualidade da democracia. Apesar da nova classificação, o modelo continua sendo o da democracia representativa, que apenas se vale de outras possibilidades de aproximação do representante com representado. Afinal, representação e participação não são termos contraditórios, sendo mais do que necessário admitir-se que a representação atenderá aos valores democráticos, quanto mais intenso for o processo participativo.

Raciocínio similar é desenvolvido com respeito à democracia eletrônica. É fato que o mundo se transformou radicalmente com o implemento das novas tecnologias de comunicação, as quais passaram a ser utilizadas para suplementar e corrigir aspectos das práticas políticas e sociais do Estado e dos cidadãos, em benefício do teor democrático da comunidade política.

248 DUVERGER, Maurice. Os partidos políticos. Trad. Cristiano Monteiro Oiticica. Rio de Janeiro: Zahar, 1970.

249 É uma teoria que, como todas as outras, suscita críticas e questionamentos. Katz e Mair afirmam de forma categórica que essa classificação não corresponde à realidade. Os partidos de quadros viram crescer sua estrutura organizacional e os partidos de massa perderam seus militantes e filiados. KATZ, Richard; MAIR, Peter. The membership of political parties in Western democracies. European Journal of Political Research, Colchester, 22, p. 329-345, 1992. Mais relevante é que as leis de Duverger são até hoje estudadas e mantêm viva a análise dessas organizações, com propostas de novas configurações. 
Entretanto, essa democracia eletrônica, democracia digital ou e-democracia denota a mesma democracia representativa, agora aprimorada e reforçada pelo uso da Internet. Os requisitos da democracia - liberdade de expressão e opinião, accountability, pluralismo, representação das minorias, dentre outros - mantêm-se inalterados. A democracia digital pode aumentar as experiências de democracia direta, mas não representa um retorno ao modelo ateniense, por meio de uma ágora virtual. As iniciativas digitais fortalecem a democracia, porém, ainda em seu standard representativo. Mesmo porque, se democracia direta houvera, os cidadãos teriam que responder a diversas perguntas sobre os mais variados temas referentes aos rumos da comunidade política. Nesse caso, quem elaboraria e determinaria o momento do questionamento? Teria de haver um grupo que orientasse esse processo. Não seriam eles representantes?

Montesquieu $^{250}$ já colocou o problema da capacidade para a discussão dos assuntos políticos. A capacidade de discutir os negócios públicos nem sempre é a condição essencial para decidir se o povo pode governar-se, o que depende mais da apreciação do mérito, da apreciação da conveniência e oportunidade da situação posta. Algumas deliberações, inevitavelmente, dependem de conhecimento especial ou técnico, para o qual o bom senso nem sempre é suficiente. Essa condição e a capacidade de apreciar todo e qualquer tipo de problema que envolva o Estado não são inerentes a todos, ${ }^{251}$ mas essa construção da democracia representativa moderna não simplifica ou altera os valores democráticos em sua essência, pois ainda estão presentes os requisitos do sufrágio universal, das eleições honestas e livres, a alternância de poder, as fontes alternativas de informação. ${ }^{252} \mathrm{O}$ importante não é retornar à democracia direta, mas melhorar a qualidade da democracia representativa. A sugestão que fica é que essa melhora ocorra via tecnologias digitais de comunicação.

250 MONTESQUIEU, Charles Louis de Secondat, baron de la Brède et de. Do espírito das leis. Trad. Gabriela de Andrada Dias Barbosa. Rio de Janeiro: Ediouro, 1985.

251 “Si por Pueblo se entende todos y cada uno de los ciudadanos, dificilmente tendrán una información adecuada sobre todos los problemas, ni tempo para adquirirla, ni muchas veces refléxion y responsabilidade para assumir todas las consecuencias de uma decisión.” SÁNCHEZ AGESTA, Luis. Democracia y processos electorales. Costa Rica: CAPEL, 1986, p. 12.

252 Dahl mencionou sua poliarquia, pois o modelo democrático ideal era - e é - inatingível. Dentre nós, Ferreira Filho defendeu ideia da democracia possível. Talvez pensar nessas aproximações do ideal democrático seja, no fundo, oferecer contribuições mais efetivas do que a exaustiva busca pelo real poder do povo. DAHL, Robert A. On democracy. New Haven: Yale University, 1998; FERREIRA FILHO, Manoel Gonçalves. A democracia possível. São Paulo: Saraiva, 1972. 
Se a democracia moderna não pode ser desprovida de representação, a democracia representativa implica a existência de uma eleição, o instrumento por excelência da governança democrática, que propicia aos cidadãos com iguais direitos a possibilidade de escolher livremente, dentre as várias opções que se apresentam, aquela que mais se coaduna com suas crenças e opiniões, influindo, assim, nas decisões da sociedade. Nesse sentido, a lição de Amado:

Não é o ato de votar que caracteriza o voto; é o nexo político entre o votante e o votado. Nos países em que há ideias políticas em jogo, o eleitor vota por suas ideias, seus pontos de vista, seus interesses; e escolhe, então, os indivíduos que a seu ver melhor representam essas ideias ou melhor podem combater por elas. ${ }^{253}$

O voto ${ }^{254}$ é o principal fator de mobilização nacional, é um exercício de poder legítimo, uma força orientada e disponibilizada em favor da cidadania e da democracia. Para se chegar ao momento do voto, é necessário estabelecer uma série de regras e procedimentos que abrangem questões de estrutura constitucional e envolvem o sistema partidário, determinando como devem ser conduzidas as eleições. É o sistema eleitoral o responsável por delimitar essas questões, podendo ser definido como

[...]a forma de expressão da vontade eleitoral, o modo como a vontade dos eleitores de escolher este ou aquele candidato, esta ou aquela candidatura, se patenteia num resultado global final, o modo como a vontade (psicológica) de cada eleitor ou dos eleitores no seu conjunto é interpretada ou transformada na vontade eleitoral (vontade jurídica que se traduz, nomeadamente, na distribuição dos mandatos ou lugares no Parlamento). ${ }^{255}$

253 AMADO, Gilberto. Eleição e representação. 3. ed. Rio de Janeiro: Sá Cavalcante, 1969, p. 52.

254 “Considerando-se que o sufrágio universal foi introduzido na Inglaterra apenas em 1918, que, na França, foi necessário esperar até 1945 para que as mulheres fossem às urnas, que nos Estados Unidos apenas há pouco mais de uma década a Suprema Corte e a constituição (24a emenda) proibiram as taxas eleitorais (poll taxes) e os testes de seleção que, em certos países, excluíam do escrutínio até $15 \%$ dos cidadãos (os negros) que tinham só teoricamente o direito do voto, pode-se dizer que o sufrágio universal é uma instituição relativamente recente.” HAMON, Francis; TROPER, Michel; BURDEAU, Georges. Direito constitucional. Trad. Carlos Souza. Barueri, SP: Manole, 2005, p. 52.

255 MIRANDA, Jorge. Manual de direito constitucional - estrutura constitucional da democracia. Tomo VII. Coimbra: Coimbra Editora, 2007, p. 61. 
Explica Caggiano: ${ }^{256}$ "Sistemas ou técnicas eleitorais configuram, na realidade, instrumentos procedimentais idealizados com vistas à seleção dos governantes pelos governados”. As técnicas eleitorais ou fórmulas eleitorais extraem o resultado das urnas e determinam o procedimento do voto, o como votar, as técnicas de escrutínio, traduzem votos das urnas em número de cadeiras e, consequentemente, definem o grau de poder.

Os sistemas eleitorais possuem várias classificações, dependendo de vários critérios, o que faz com que o pesquisador circule por um terreno árido e complexo, mas, ao mesmo tempo, instigante, de maneira que o tema é objeto de tantas obras nacionais e internacionais que brindam os estudiosos com sua ótica inovadora.

De acordo com a didática classificação trazida por Jairo Nicolau, ${ }^{257}$ os sistemas eleitorais podem ser divididos em dois grandes grupos: representação majoritária e representação proporcional.

O sistema majoritário fundamenta-se em uma ideia simples: considera-se eleito o candidato que obtiver maior número de votos. Essa regra da maioria, em um sistema democrático, parece ser muito razoável, porque indica o grupo com maior expressão política e que, em decorrência, deveria se impor nessa seara.

Deve-se levar em consideração, todavia, a observação de Silva:

A importância da regra da maioria nos regimes democráticos é indiscutível, mas maioria e democracia não são expressões equivalentes e nem mesmo estão relacionadas. Em primeiro lugar, pode haver utilização da regra da maioria sem que haja democracia, quando aquela é utilizada com o simples propósito de esmagar os direitos das minorias. [Assim] a regra da maioria é simplesmente uma regra dentre outras a serviço da democracia, é meramente uma das formas da tomada de decisão, que não pode ser elevada a um princípio democrático. ${ }^{258}$

256 CAGgIANO, Monica Herman Salem. Sistemas Eleitorais x Representação Política. 1987. Tese (Doutorado em Direito) - Faculdade de Direito da Universidade de São Paulo. São Paulo, 1987, p. 11.

257 NICOLAU, Jairo Marconi. Sistemas eleitorais. 5. ed. Rio de Janeiro: Editora FGV, 2004, p. 10.

258 SILVA, Luís Virgílio Afonso da. Sistemas eleitorais. tipos, efeitos jurídico-políticos e aplicação ao caso brasileiro. São Paulo: Malheiros, 1999, p. 127. Sartori apresenta ideia no mesmo sentido, indagando: por que usar a regra da maioria, e não a regra da unanimidade? O cientista italiano entende que esses são critérios de tomada de decisão, e que a regra da maioria não pode ser defendida 
O objetivo principal do sistema majoritário ${ }^{259}$ é respeitar a decisão dos cidadãos, que depositam a maior quantidade de votos em determinados candidatos, os quais asseguram, com isso, maioria parlamentar suficiente para facilitar a governabilidade.

Retomando a classificação de Nicolau, a eleição pelo sistema majoritário pode dar-se por maioria simples, dois turnos e voto alternativo. ${ }^{260}$

Pelo sistema da maioria simples, reputa-se eleito o candidato com maior número de votos. Os partidos indicam um candidato por distrito e os eleitores votam em um só nome.

O método da maioria absoluta tem algumas distorções. Primeiro, pode dar origem à ballotage, processo que acarreta a repetição da eleição até que algum candidato obtenha mais da metade dos votos. ${ }^{261}$

Ademais, distritos que representam forte concentração de votos num partido podem eleger vários candidatos, enquanto outro partido, com votos dispersos, elegerá menos candidatos, ainda que obtenha maior percentual de votos no total, gerando alto índice de desproporcionalidade.

É um sistema que, mesmo garantindo maioria absoluta de votos, pode não conquistar a maioria absoluta de assentos, ou seja, o maior número de votos não garante a estabilidade governamental. ${ }^{262}$

“incondicionalmente”. SARTORI, Giovanni. Teoria da democracia revisitada. Vol. I - o debate contemporâneo. Trad. Dinah Azevedo. São Paulo: Ática, 1994, p. 192.

259 O sistema da maioria simples é conhecido no Brasil como "voto distrital puro". Há países que exigem a inscrição de um suplente, que substitui o eleito que não puder assumir ou continuar o mandato. Para os cargos do Poder Executivo, geralmente o candidato é eleito com um vice. No Brasil, para o cargo de senador, são eleitos dois suplentes para cada.

260 NICOLAU, Jairo Marconi. Op. cit., p. 10.

261 “O termo é originário do vocabulário inglês "ballot”, o qual pode identificar tanto o voto, como o escrutínio, o próprio processo de votação e a cédula que contém os nomes dos candidatos concorrentes.” CAGGIANO, Monica H. Salem. Sistemas Eleitorais x Representação Política, p. 139.

262 SILVA, Luís Virgílio Afonso da. Op. cit., p. 130. 
Destaque para a distorção causada pelo gerrymandering, ${ }^{263}$ uma manipulação das fronteiras dos distritos eleitorais que ocorre na representação majoritária e que distorce igualmente o resultado do sistema. ${ }^{264}$

Em sua defesa, os analistas entendem que esse método estimula uma relação mais estreita entre o representante e o eleitor, possibilitando a obtenção de partidos majoritários no parlamento, isto é, favorece o bipartidarismo, ${ }^{265}$ circunstância que favorece a governabilidade e define de forma clara o papel de cada partido, o que, para o eleitor, é significativo, não apenas na hora de acompanhar as políticas implementadas, mas também no que se refere à questão da responsabilidade política.

Insta salientar o argumento levantado pelo jurista português Canotilho:

A democracia tem como suporte ineliminável o princípio majoritário, mas isso não significa qualquer "absolutismo da maioria" e, muito menos, o domínio da maioria. O direito de maioria é sempre um direito em concorrência com o direito das minorias com o consequente reconhecimento de estas se poderem tornar maiorias. A maioria não pode dispor de toda a "legalidade", ou seja, não lhe está facultado, pelo simples facto de ser maioria, tornar disponível o que é indisponível, como acontece, por exemplo, com os direitos, liberdades e garantias, em geral, com toda a disciplina constitucionalmente fixada. ${ }^{266}$

O sistema majoritário em dois turnos em muito se assemelha ao sistema majoritário simples, entretanto, aquele exige que um dos concorrentes obtenha a maioria

263 O nome é dado em alusão ao governador Eldridge Gerry, do Estado norte-americano de Massachusetts, que criou um Estado em forma de uma salamandra (salamander) para beneficiá-lo nas eleições. O nome gerry + salamander formou o termo em questão. NICOLAU, Jairo Marconi de. Op. cit., p. 14.

264 Um sistema condenável em todos os aspectos, mas que é aceito nos Estados Unidos: “[...] it should be clear that gerrymandering is an abuse, a shameful rigging, [...] but it has acquired in the United States a court-enforced legitimacy and also a rationale as a means to secure ethnic representation." SARTORI, Giovanni. Comparative constitutional engineering. 2. ed. New York: New York University Press, 1997, p. 21.

265 Duverger introduziu duas proposições sobre os sistemas eleitorais que se tornaram clássicas. A primeira é que o sistema majoritário de um só turno tende ao dualismo de partidos. A segunda é que o sistema majoritário de dois turnos e a representação proporcional tendem ao multipartidarismo. DUVERGER, Maurice. Op. cit., p. 234-280. Essas assertivas foram alvo de vários testes e críticas, todavia, se analisadas pelo viés da probabilidade e tendência estrutural, merecem crédito e reconhecimento.

266 CANOTILHO, J.J. Gomes. Direito constitucional. 6. ed. Coimbra: Almedina, 1993, p. 456. 
absoluta $^{267}$ dos votos. Se isso não ocorrer, os candidatos mais votados terão que se submeter a novas eleições.

Conforme seus defensores, esse modelo garante que os eleitores sejam eleitos com votações expressivas. No sistema de maioria simples, como não existe a exigência de mais de $50 \%$ dos votos, o candidato pode ser eleito mesmo tendo obtido poucos apoios. Ademais, favorece a eleição de partidos mais moderados, porquanto, havendo segundo turno, haverá também a exigência de formação de alianças, mais difícil de ocorrer entre grupos extremistas.

E ainda existe a versão de voto majoritário denominado voto alternativo:

O voto alternativo garante que todos os eleitos receberão maioria absoluta dos votos sem necessidade de realizar uma nova eleição. $\mathrm{O}$ segredo é a utilização de um método de transferência de votos dos candidatos menos votados para outros. ${ }^{268}$

Esse método é alcançado da seguinte forma: no momento do voto, o eleitor ordena os candidatos de acordo com sua preferência. Quem obtiver maioria absoluta na primeira preferência é eleito. Se isso não acontece, é feita a transferência das cédulas do candidato menos votado para os outros, até que outro candidato alcance mais de $50 \%$ dos votos. É o sistema adotado na Austrália.

Visando a resolver as distorções do sistema majoritário, foi construído o modelo do sistema proporcional, que garante que os cargos em disputa tenham sua distribuição ordenada de modo proporcional à votação recebida pelos concorrentes.

É um sistema que valoriza a justiça do pleito e favorece a representação das minorias, sendo, por isso mesmo, considerado o mais representativo. Ele assegura que

267 A CF/88, em seu art. 77, § 2º preceitua que será eleito Presidente da República o candidato com maioria absoluta de votos, não computados os brancos e nulos, o mesmo se aplicando à eleição dos Governadores de Estado e do Distrito Federal e dos Prefeitos de municípios com mais de duzentos mil eleitores.

268 NICOLAU, Jairo Marconi. Op. cit., p. 26. 
as diversas correntes de opinião estejam representadas no parlamento, propiciando que o percentual das votações partidárias corresponda ao número de cadeiras conquistadas. ${ }^{269}$

Portanto, se no sistema majoritário o cidadão elege um candidato, no sistema proporcional ele elege uma corrente de opinião, personificada no partido político.

Ao permitir a representação das minorias, consegue dar espaço a uma ampla camada da população, reproduzindo de maneira mais apurada a vontade do eleitorado. Nesse sentido, reflete Caggiano:

A realidade proporcional, ao revés, ajusta-se de forma mais adequada ao cânone da representação, conduzindo-o a um nível mais próximo do ideal, na medida em que assegura a presença de numerosos e diversificados segmentos da comunidade junto à esfera da discussão e decisão dos negócios públicos. Valoriza, destarte, o voto de um número mais significativo de eleitores, demonstrando maior fidelidade ao standard do one man, one vote. ${ }^{270}$

A representação gira em torno de três ideias fundamentais, como explica Bercovici:

A primeira é a do mandato livre e independente, isto é, de que os representantes eleitos, ao serem eleitos, não têm nenhuma obrigação, necessariamente, para com as reivindicações e os interesses de seus eleitores. [...]A segunda ideia é a de que os representantes devem exprimir interesses gerais, e não interesses locais ou regionais. Em terceiro, o princípio de que o sistema democrático representativo deve basear-se no governo da maioria. ${ }^{271}$

O sistema majoritário não perdurou no Brasil. Durante o Império e a República Velha foi adotado o voto distrital, porém, com a entrada em vigor do Código Eleitoral de $1932,{ }^{272}$ adota-se o modelo do sistema proporcional, o qual adota os quocientes eleitoral e partidário, tendo sido influenciado pelas propostas de Joaquim Francisco de Assis Silva.

269 Amado corrobora o pensamento: "Os sistemas de representação proporcional adotados nas legislações eleitorais modernas representam o esforço da democracia na conquista da distribuição equitativa do voto.” AMADO, Gilberto. Op. cit., p. 79.

270 CAGGIANO, Monica Herman S. Op. cit., p. 201.

271 BERCOVICI, Gilberto. A origem do sistema proporcional no Brasil. Estudos eleitorais, Brasília, v. 1, n. 1, p. 53, 1997.

272 Decreto $^{\circ}$ 21.076/32, alterado pela Lei no $48 / 35$. 
Como elucida Kinzo, ${ }^{273}$ Assis Brasil apresentou seu projeto à Câmara no ano de 1893, defendendo mudança no sistema de escolha de representação à Câmara. Pela sua proposta, deveriam ser abolidos os distritos eleitorais, sendo instituída a representação por Estado por meio do escrutínio em dois turnos simultâneos, proporcional no primeiro e majoritário no segundo. Foi essa visão que deu suporte ao estudo do sistema de representação proporcional, desde então.

Bercovici assinala que Assis Brasil buscava a ampliação da circunscrição eleitoral para os Estados, pois isso “[...] contribuiria para que os deputados se ativessem a temas de importância nacional, não local.” ${ }^{274}$ Naquela época (e, dizem muitos, até hoje), como destacado por historiadores, a mistura entre o público e o privado ilustrava o tom dominante na estrutura institucional brasileira e provocava a descrenças nessas instituições, além do desinteresse político. A intenção de Assis Brasil com o voto proporcional era “[...] refletir os diversos matizes da opinião pública”, ${ }^{275}$ possibilitando o acesso das minorias ao parlamento.

O sistema adotado por ele era híbrido, proporcional e majoritário, com mais ênfase nesta última estrutura. Contudo, no fundo, a questão da proporcionalidade não era a mais importante. O que pretendia Assis Brasil era abolir o voto distrital:

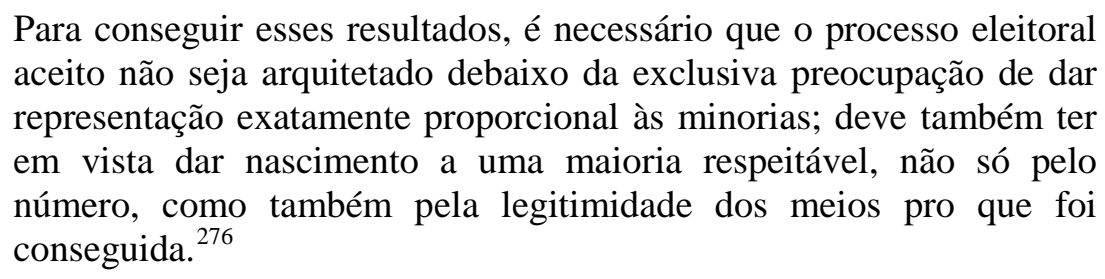

O modelo atual de representação proporcional comporta duas versões: sistema de número uniforme e sistema de quociente eleitoral (tecnicamente conhecido como quociente Hare). ${ }^{277}$ Pelo primeiro, a lei fixa o número de votos que deve ser obtido para que a lista eleja um deputado, sendo que o partido terá tantos eleitos quantas vezes

273 KINZO, Maria D’Alva Gil. Representação política e sistema eleitoral no Brasil. São Paulo: Símbolo, 1980, p. 118-131.

274 BERCOVICI, Gilberto. Op. cit., p. 57.

275 KINZO, Maria D’Alva Gil. Op. cit., p. 133.

276 ASSIS BRASIL, Joaquim Francisco. Op. cit., p. 146-147.

277 Modelo desenvolvido pelo jurista Thomas Hare, em 1859, e apoiado por John Stuart Mill. In: NICOLAU, Jairo Marconi. Op. cit., p. 38. 
obtiver o número uniforme estabelecido. Tomar-se-á conhecimento do número de deputados apenas após as eleições, visto que esse número dependerá da quantidade de votos ativos, quer dizer, da participação eleitoral.

A segunda versão depende de sucessivas operações aritméticas, realizadas a partir do quociente eleitoral e do quociente partidário para estipular o preenchimento de vagas. De acordo com o art. $5^{\circ}$ da Lei $n^{\circ}$ 9.504/97, o quociente eleitoral resulta da divisão do número de votos válidos (os votos brancos e nulos são excluídos) pelo número de mandatos a serem conferidos. Para se chegar ao quociente partidário, deve-se obedecer à regra do art. 107 do Código Eleitoral. Divide-se a votação obtida por cada partido pelo quociente eleitoral, restando definido o número de parlamentares eleitos, sendo as sobras distribuídas aos partidos.

O sistema proporcional pode ser de lista fechada, pelo qual o eleitor vota em uma lista de candidatos previamente determinada pelos partidos, apurando-se o total de votos que a lista recebeu, ou de lista aberta, que dá liberdade ao eleitor, dentro de uma lista partidária, de escolher seus candidatos.

No sistema proporcional, pode ocorrer que um partido ou coligação tenha recebido expressivo número de votos concentrados num só ou em poucos candidatos, o que provoca o fenômeno de esse candidato “atrair” outros de seu partido ou coligação, ${ }^{278}$ elegendo-os, também, ainda que sem expressiva votação individual. A distorção observada é que vários partidos deixam de eleger candidatos de votação considerável em virtude de seus votos estarem pulverizados entre muitos candidatos.

As propostas de reforma política em tramitação, no Brasil, sugerem a criação de federações de partidos, que os vincularia por quase toda a legislatura, de modo a coibir as coligações oportunistas, sendo alternativa ao estabelecimento da cláusula de exclusão.

278 Exemplo recente é do fenômeno Tiririca, que recebeu votos de 1,35 milhão de eleitores, levando para a representação da bancada de São Paulo Protógenes Queiroz (PCdoB), Otoniel Lima (PRB) e Vanderlei Siraque (PT). Este último teve apenas 93.314 votos, mas se elegeu deputado federal, devido a esse complexo sistema de quociente eleitoral. 
A cláusula de exclusão é o estabelecimento de um piso de votos, tanto nacionalmente quanto no distrito, a fim de impedir a proliferação de partidos de pouca expressão. A justificativa contra a existência de inúmeros partidos é que, além de dificultar a composição de uma base coesa de sustentação ao governo, no parlamento, tal situação cria dificuldade na distribuição de verbas eleitorais e de publicidade publicitária (horário gratuito na TV e no rádio). Favorece, em acréscimo, a existência de conchavos e o "aluguel” de partidos chamados "nanicos” aos partidos maiores, em troca de favores políticos, comprometendo a lisura dos pleitos, o fortalecimento das instituições políticas e a própria governabilidade.

Sobre a questão da proporcionalidade do voto, há uma larga bibliografia. Tanta atenção dada ao tema, infelizmente, ainda não conseguiu levar à correção dessa desigualdade, no sistema brasileiro.

Dispõe o art. 45 da CF:

O número total de Deputados, bem como a representação por Estado, e pelo Distrito Federal, será estabelecido por lei complementar, proporcionalmente à população, procedendo-se aos ajustes necessários, no ano anterior às eleições, para que nenhuma daquelas unidades da Federação tenha menos de oito ou mais de setenta deputados.

Embora proporcional, na eleição para a Câmara dos Deputados, o eleitor só pode votar em candidato do seu Estado. Por isso é que se chega à situação de o Acre, que não possui nem um milhão de habitantes, ter o mesmo número de senadores que os demais Estados, e oito deputados, em manifesta desproporcionalidade ${ }^{279}$ com a subrepresentação de Estados mais populosos. Cria-se no Congresso uma falsa maioria, formada por representantes de Estados menos desenvolvidos e populosos. Isso distorce a representação dos Estados e dos partidos, já que as forças políticas acabam sendo repartidas de forma desigual pelos Estados. Essa é uma das questões mais sérias do Brasil, uma deformação do voto que perpetua o conservadorismo oligárquico.

279 Problema cuja origem está na transformação dos ex-territórios do Amapá e Roraima em Estados, e na criação do Estado do Tocantins, na Assembleia Constituinte de 1987/1988, com a fixação de número de deputados entre oito e setenta. 
Esse sistema também tende a favorecer a proliferação de partidos, dificultando os arranjos institucionais que buscam facilitar a execução das políticas de governo.

Outrossim, na eleição proporcional, o voto é do partido, responsável pela elaboração das listas, geralmente determinada pela militância partidária, o que remete, mais uma vez, à ideia da oligarquia nos partidos.

Os efeitos salutares do sistema proporcional, por sua vez, são muitos. Uma de suas principais vantagens é que todos os votos contam na distribuição dos mandatos, de uma maneira ou de outra. Afinal, o voto contribui no cálculo do quociente partidário. Mais importante é o ganho na representação das minorias, pois, não importa o peso que elas apresentem, elas “[...] terão a representação proporcional a essa força, o que faz com que não sejam somente os maiores grupos minoritários que tenham chance de obter representantes.”280

Assegurada está a liberdade do eleitor na manifestação de seu voto, seja no candidato, seja no partido, porque todos têm chance a uma cadeira, especialmente se o voto for partidário. E isso se reflete no Parlamento, com várias correntes de pensamento sendo ali representadas.

No sistema proporcional, as circunscrições eleitorais são plurinominais, o que afasta a incidência do gerrymandering, pela impossibilidade de divisão dos partidos de oposição e situação.

A despeito de tantos pontos positivos, para muitos estudiosos do processo eleitoral brasileiro, os problemas trazidos pelos desvios de representação do modelo proporcional são de um vício insuperável, de sorte que defendem a adoção do sistema distrital como forma de melhorar a representatividade no parlamento.

Como já mencionado, o sistema de votação por distritos surgiu no Segundo Reinado, com a Lei dos Círculos, foi abolido em 1875 e restabelecido em 1881, pela Lei do Censo. Ele perpassou a República e foi extinto pelo Código Eleitoral de 1932.

280 SILVA, Luís Virgílio Afonso da. Op. cit., p. 137. 
Proposituras mais recentes são lembradas por Caggiano, ${ }^{281}$ como a do ministro Edgard Costa, de 1958, e o projeto de Franco Montoro, que pretendeu trazer o sistema distrital misto alemão para o Brasil.

Haveria duas possibilidades: uma delas seria o modelo inglês, com o sistema distrital majoritário, ganhando o partido que obtivesse maioria de votos. Ou, então, o modelo alemão do voto distrital misto, pelo qual metade do Parlamento é eleito pelo eleitor nacional e a outra metade provém dos distritos regionais, refletindo as orientações locais.

O sistema distrital é temerário em um país como o Brasil, onde há muitas tensões sociais e as instituições políticas são constantemente questionadas. Afinal, se adotado o sistema distrital puro, que equivale ao sistema majoritário, o candidato eleito pelo distrito deixa de ser o representante da nação, para se tornar o defensor dos interesses de uma determinada região que o escolheu, “[...] configurando, a situação, um retrocesso aos princípios da linha evolutiva do governo representativo.”282

Importante ressaltar que ele possui alto potencial corruptivo, principalmente em países com falta de maturidade política e cultural e bolsões de pobreza a se acumular em circunscrições eleitorais. De notar, também, o “[...] coronelismo distrital, [...] baseado no poder econômico ou no temor reverencial”, ${ }^{283}$ especialmente nessas mesmas áreas mais pobres ou distantes dos grandes centros, sem muitas perspectivas de trabalho ou do mínimo de subsistência. Há casos, aliás, de candidatos que mudam seu domicílio eleitoral para outro Estado remoto da Federação, com a pretensão de ganhar a eleição de um modo mais fácil. Por isso mesmo é que, até os que defendem o voto distrital o fazem na sua versão voto distrital misto, nunca na idealização pura do sistema.

Há de se apontar a análise de Silva sobre o sistema misto, que combina a representação proporcional com a eleição majoritária, correspondendo ao sistema alemão acima referido. Esse estudioso do tema ressalta que essa interpretação é errônea.

\footnotetext{
281 CAGGIANO, Monica Herman S. Op. cit., p. 94.

282 CAGGIANO, Monica Herman S. Op. cit., p. 93.

283 BARROS, Sérgio Resende de. O voto distrital. Disponível em: <http://www.srbarros.com.br/pt/ovoto-distrital.cont>. Acesso em: 07 jul. 2013.
} 
Existem apenas sistemas proporcionais e majoritários. O sistema alemão, se mais bem observado, atende ao princípio proporcional, pois os resultados são proporcionais. Dessa forma, essa classificação não deveria ser adotada. ${ }^{284}$

Diante disso, conclui-se que o modelo proporcional merece ser aprimorado, mas não descartado. Problemas há, contudo, há também alternativas para sua correção. Não se devem procurar modelos estrangeiros, neste momento, porque a democracia brasileira é recente e precisa encontrar suas próprias soluções. É uma democracia que ainda está amadurecendo, possui apenas 25 anos e, apesar de suas instituições terem se mostrado resistentes a tantos casos de corrupção política, denúncias, abusos de poder, elas fazem parte de um delicado regime, que depende da constante vigilância do cidadão. A cidadania precisa estar atenta, pois ela fiscaliza a democracia. Uma das formas dessa fiscalização é pelo voto, por óbvio, já que é através dele que os cidadãos elegem os governantes, que, em princípio, defenderão os interesses do demos, praticando a boa governança.

Além do voto, a Constituição de 1988 ampliou os instrumentos de controle dos representantes, com a instituição de mecanismos que possibilitam o controle de aplicação das normas constitucionais, como mandado de injunção e ação direta de inconstitucionalidade por omissão. O cidadão ganhou papel de destaque; basta que seus instrumentos sejam acionados. ${ }^{285}$

Em acréscimo, talvez o mais importante seja, mais uma vez, o fortalecimento da democracia. A essência do processo decisório democrático não é a escolha feita pelo sistema eleitoral, mas as ideias que circulam entre partidos e sociedade entre as eleições. A recuperação dos mecanismos representativos e, com especial atenção, dos partidos políticos, tem que estar vinculada à melhora da qualidade da democracia, contemplando questões ligadas à agenda política, aos meios de comunicação de massa, meios tecnológicos de comunicação e à ampliação dos espaços de produção de debates e de implementação dos interesses coletivos.

284 SILVA, Luís Virgílio Afonso da. Op. cit., p. 169.

285 Pesquisas apontam, por exemplo, que a grande maioria de mandados de injunção é impetrada pelos partidos políticos, o que faz dele um instrumento da minoria, contrariando o espírito legal. 


\subsection{O papel dos partidos políticos no processo eleitoral}

O cenário delineado até este ponto desvenda um aspecto evidente hoje em dia: o poder central, o sistema decisional, ou seja, o próprio Estado não consegue modelar com a propriedade requerida um novo sistema representativo que consiga ouvir e atender às tão variadas demandas sociais. O modelo brasileiro de sistema eleitoral consegue resistir às pressões mais fortes, mas não possui os meios materiais nem a legitimidade ideológica para analisar demandas de contornos específicos. Talvez o pior problema não seja nem mesmo o Estado, mas os partidos políticos, que precisam desenvolver uma nova forma de se aproximar do sistema representativo, sugerindo - ou se abrindo para - novas formas de participação.

\subsubsection{Origem e evolução dos partidos políticos}

Desde os clássicos trabalhos de Ostrogorski ${ }^{286}$ e Michels, ${ }^{287}$ os partidos políticos têm sido objeto de estudo recorrente das ciências políticas e jurídicas. Tantas obras postas à disposição do analista não facilitam um olhar percuciente sobre esse instituto político que é indispensável para as democracias ocidentais ${ }^{288} \mathrm{e}$, ao mesmo tempo, passa por um longo processo de colapso por não conseguir atender plenamente ao seu objetivo principal de promover a intermediação entre eleitores e políticos. ${ }^{289}$

Moisei Ostrogorski apresenta obra seminal sobre os primórdios desse instituto e examina como o processo de burocratização e profissionalização dos partidos, na Inglaterra e nos Estados Unidos, faz com que os partidos se convertam em oligarquias.

Ostrogorski é um defensor do sistema de governo democrático, cuja maior virtude é ver seus líderes eleitos pelo povo. A tarefa da educação política e da percepção da importância de uma escolha consciente seria feita pelos partidos políticos,

\footnotetext{
286 OSTROGORSKI, Moisei. La démocratie et les partis politiques. Paris: Calmann-Lévy, 1912.

287 MICHELS, Robert. Sociologia dos partidos políticos. Brasília: Universidade de Brasília, 1982.

288 Duverger, mestre inconteste sobre o tema, assim declara: "Sans partis politiques, le fonctionnement de la répresentation politique, c'es-à-dire de la base même des institutions libérales , est impossible.” DUVERGER, Maurice. Institutions politiques et droit constitutionnel. Vol. 1 - Les grands systèmes politques. 13. ed. Paris: Presses Universitaires de France, 1973, p. 91.

289 Uma situação, aliás, que vem sendo absorvida pelos meios de comunicação de massa, como abordaremos em momento próprio.
} 
organizações que, por terem esse fim, apenas contribuiriam positivamente para o processo democrático.

Só que, ao construir o corpo teórico de sua obra, o autor se depara com vários problemas que se tornam obstáculos para a confirmação dessa perspectiva.

A fim de localizar o surgimento dos partidos, Ostrogorski observa a relevância da organização política extraparlamentar, ${ }^{290}$ comum no regime inglês, a qual remonta ao século XVIII, quando surgem os primeiros movimentos que se rebelam contra os casos de corrupção existentes no Parlamento, à época. E, quando Wilkes, deputado londrino regularmente eleito, é expulso do Parlamento, funda-se a primeira associação política, chamada de "Société pour soutenir le bill des droits", 291 no ano de 1769.

Desde essa época, as constantes demandas pela reforma da representação parlamentar dão origem aos "comités de correspondance”, criados para derrubar a oligarquia parlamentar.

A Revolução Francesa propicia o surgimento de várias sociedades que conclamam pelo sufrágio universal. A burguesia firmada no cenário francês, apesar de ter obtido êxito na ordem econômica do país, fica excluída do poder político e decide se unir às massas, para formar as “unions politiques”.

A massa operária, que não obtinha a franquia eleitoral, mantém o espírito agitado em busca dessa conquista e forma o movimento denominado "Chartism”, o qual estimula a formação de outras sociedades reformistas. ${ }^{292}$

290 No mesmo sentido: "Los partidos nacieron como asociaciones espontáneas, incluso cuando en muchos países no estaba regulado el derecho de asociácion. El reconocimiento de este derecho y del derecho de libre expresión del pensamento fueron el cuadro jurídico mínimo bajo el que se constituyeron. In: SÁNCHEZ AGESTA, Luis. Principios de teoria política. 6. ed. Madrid: Nacional, 1976, p. 257.

291 OSTROGORSKI, Moisei. Op. cit., p. 43.

292 Ostrogorski menciona a expansão da formação de associações na Inglaterra, destacando os movimentos e grupos contrários às tendências democráticas e aos grupos religiosos, o que provoca uma reação dos católicos ingleses e irlandeses, levando à formação da “Association catolique”, que se erige como poder rival do governo e consegue seu ato de emancipação votado pelo Parlamento, em 1929, o que representa uma conquista histórica, por ser "[...] la première fois qu'une mesure législative fut imposée par la pression d’une organisation politique.” OSTROGORSKI, Moisei. Op. cit., p. 44. 
Assim, de modo breve, percebe-se que a pressão provocada pelas organizações localizadas fora do Parlamento derrubaram barreiras e abriram novos caminhos para as demandas sociais, ampliando a base da representação popular.

Até esse tempo não havia partidos organizados que reunissem eleitores em torno de uma ideologia. Os eleitores se reuniam por serem da mesma família ou por terem um rival comum. Os pequenos proprietários gravitavam em torno do grande senhor de terras da região, enquanto os burgos ainda dependiam diretamente dos magnatas territoriais, caracterizados como aqueles que tinham muitas posses ou que eram provenientes de uma família importante. Como se vê, não havia atuação partidária sobre os eleitores.

Na verdade, até havia partidos dentro do Parlamento, mas eles não mostravam suas plataformas ao povo; a atuação era literalmente feita pela compra de deputados ou de burgos parlamentares, isto é, se as cotas parlamentares não obtinham o apoio necessário para fortalecer o governo ou a oposição, entravam em cena os chamados whips, designados pelo líder partidário para conhecer os membros de cada partido, seus pontos fracos e fortes, mostrando a eles quais eram os planos e objetivos do líder político e quais seriam as funções de cada um para atingi-los. Ressalta Ostrogorski que a autoridade dos whips era puramente moral, “[...] il ne tient que du prestigie et de son tact”293 e, com isso, conseguiam garantir união e coesão de cada partido.

Esse posto havia sido criado para deter a corrupção que tomava conta do Parlamento - já naquela época - com o dinheiro sendo distribuído de mão em mão. $\mathrm{O}$ trabalho era tão grande que foi até mesmo instituído um cargo especial de secretário político da tesouraria para ajudar na tarefa. ${ }^{294}$

É somente após o Ato de 1832 que ocorre uma mudança nesse cenário parlamentar, com a instituição das listas eleitorais. Antes disso, elas não existiam: o funcionário que presidia as eleições conferia os títulos eleitorais daqueles que se

293 OSTROGORSKI, Moisei. Op. cit., p. 48. Eles possuíam apenas prestígio e trato político, sabiam lidar com todos, impondo sua força moral.

294 “Les ministres achetaient les membres de leur majorité, leur remettaient de l'argent de la main à la main; ils avaient à la Chambre même un guichet où les députés venaient toucher le prix de leur vote après le scrutin. Le premier lord de la trésorerie, ayant trop à faire, établit, em 1714, le poste de secrétaire politique de la trésorerie, pour l’aider dans ces opérations financières.” (Op. cit., p. 48). 
apresentavam para votar, de sorte que uma eleição para um deputado do Parlamento tinha a duração de meses, tornando-se inviável à medida que se multiplicava o número de eleitores.

O registro, todavia, não era assim tão simples; a admissão de alguns eleitores era alvo de protestos, caso não estivessem presentes as qualificações necessárias para tanto e, da mesma maneira, o eleitor que não tivesse seu nome incluído poderia contestar o fato na justiça, com possibilidade de apelação, o que prolongava o processo de registro por um longo período.

No fundo, os eleitores não estavam muito preocupados com esse registro, o que gerou um problema a ser enfrentado pelos candidatos. Sem eleitores, não haveria eleição, obviamente. Assim, os candidatos começaram a ajudar os eleitores a passar por todos os processos formais que lhes fornecessem o registro eleitoral, tendo sido esse o motivo que despertou o espírito partidário, à época. ${ }^{295}$

A abordagem do autor sobre o que se exigia para que o candidato conquistasse a preferência do eleitor é impressionante pela atualidade do texto, escrito no começo do século XX. Muito pouco mudou.

Primeiramente, o bom candidato precisava ter boa renda, pois o dinheiro atrai correligionários políticos e ajuda a subvencionar o próprio partido, durante a campanha. Além disso, ele deveria ter um comportamento conciliador, a fim de conquistar os mais diversos eleitores, que, às vezes, faziam sua escolha em função de uma tendência valorativa qualquer ou apenas seguiam uma tradição familiar, além daqueles que obedeciam a seus sentimentos de devoção. ${ }^{296}$ Como a atuação política acontecia apenas

295 Interessante notar que alguns comerciantes se opunham à obtenção do registro eleitoral, já que eles indicavam a preferência política do eleitor, e isso poderia afastar a clientela. Assim, “[...] la menace de retirer la clièntele aux boutiquiers s’il votaient pour l'autre parti était à cette époque un des moyens de propagande politique, et des plus efficaces.” (Op. cit., p. 51).

296 "La religion du parti politique réunit également au jour solennel du scrutin tous ses fidèles pour les faire communier et affirmer leur foi en la personne du candidat”. OSTROGORSKI, Moisei. Op. cit., p.202. 
de tempos em tempos, nos anos eleitorais, era importante que Estados e partidos atuassem para afastar a apatia política. ${ }^{297}$

Esse falta de interesse pela "coisa pública”, problema constatado até hoje como um dos grandes males para o fortalecimento democrático, decorre da falta de responsabilidade do indivíduo com a sociedade. O que importa é aumentar a fortuna pessoal. Ao partido caberia se preocupar com as questões de interesse público. Porém, se os cidadãos não se envolviam com as mudanças e projetos sociais, por que esperar isso dos partidos? A consequência desse alheamento foi a de os partidos desrespeitarem e leiloarem a "coisa pública”, mantendo os casos de corrupção e clientelismo que outrora eram combatidos e deixando de promover a educação política, o que gerava uma espiral de ignorância da população e desonestidade daqueles que deveriam fazer a intermediação junto ao Parlamento.

Ostrogorski percebeu ainda, com suas pesquisas e coleta de depoimentos, que as pessoas que trabalhavam para a máquina partidária eram, geralmente, pouco conceituadas para assumir essa posição. Muitos deles tinham problemas com a justiça, não revelavam nenhuma instrução básica, eram ignorantes, ou careciam mesmo de princípios e valores morais. Por terem conseguido certo status social, eram gratos ao partido, fazendo tudo o que lhes era solicitado. Afinal, se eles se voltassem contra a máquina que faziam funcionar, além de serem expulsos dessa estrutura, poderiam ver seus nomes e seus desvios expostos para toda a sociedade.

Destaca-se o uso da imprensa escrita pelos dois partidos observados - os Caucus e os Rings. Como poucos possuíam educação básica e os partidos não cumpriam sua função de educador político, as informações que chegavam ao povo eram veiculadas pelas próprias organizações partidárias, as quais escreviam e divulgavam aquilo que lhes parecesse mais significativo, nos jornais, panfletos e anúncios. Fácil de constatar a grande manipulação da opinião pública por essas “verdades” dos partidos.

Assim, ocorria uma nítida oligarquização dos partidos, que mantinham suas lideranças no poder por muito tempo, com a transferência do poder de decisão,

297 “Ces sentiments ne se manifestent, peut-être,que par intervales; cachés sous l'apathie politique qui envahit la majorité des électeurs pendant les années qui séparent les élections générales l'une de l'autre, ils subsistente néanmoins à l’état latent."297. OSTROGORSKI, Moisei. Op. cit., p.201. 
passando da base para a cúpula. Os representados perdiam o controle do que acontecia dentro dos partidos, os quais iam mantendo seus benefícios. A principal conclusão é que a organização do partido em si é perniciosa.

Robert Michels também apresenta estudo célebre sobre a oligarquia política dos partidos, no livro Sociologia dos partidos políticos, de 1910. Sua famosa "lei de ferro” sofreu influência dos escritos de Ostrogorski e pode ser explicada pela passagem abaixo:

Em qualquer organização, trate-se de um partido político, de uma união profissional, ou de qualquer outra associação do tipo, a tendência aristocrática manifesta-se muito claramente. O mecanismo da organização, ao mesmo tempo em que confere solidez estrutural, conduz a sérias mudanças na massa organizada, invertendo completamente a posição respectiva de líderes e liderados. Como resultado da organização, todo partido ou associação profissional divide-se em uma minoria dirigente e uma maioria dirigida. [...] É a organização que dá origem à dominação dos eleitos sobre os eleitores, dos mandatários sobre os mandantes, dos delegados sobre os delegantes. Quem diz organização diz oligarquia. ${ }^{298}$

Portanto, para o autor, era impossível haver democracia em organizações e sociedades complexas, e a comprovação de sua tese recai sobre o estudo do Partido Social-Democrata Alemão (SPD), um partido de massa moderno, que tinha em sua gênese o aprimoramento da democracia política.

Michels traça uma análise sociológica dos organismos políticos e constata que um partido precisa ter uma organização estável, com divisão e especialização de funções, e uma classe dirigente, que consiga manter essa organização atuando de forma eficaz, exatamente porque possui conhecimento técnico e é capaz de elaborar as estratégias de atuação dos partidos políticos.

Essa situação leva, inexoravelmente, a um afastamento da liderança política em relação aos demais membros do partido, causando uma perda de legitimidade nesse processo.

298 MICHELS, Robert. Op. cit., p. 238. 
Segundo Michels, uma estrutura pequena, com poucos membros, poderia até se valer da democracia direta para a tomada de decisões, mas ela não conseguiria se sustentar, havendo uma necessidade de reformulação que resultaria no modelo de representação. Com isso, alguns militantes passariam a formar uma elite dirigente, que tentaria a todo custo manter o poder, impedindo a renovação dos quadros partidários. A manutenção do poder provoca o abandono de causas em prol da coletividade, o que não se coaduna com a construção do termo democracia.

Partido político, para o estudioso alemão, não é uma unidade social nem econômica, é uma estrutura de organização das massas eleitorais que objetiva ganhar mais adesões e mais votos, dando continuidade à sua estrutura oligárquica, a qual fornece vantagens financeiras e privilégios para seus líderes. Assim expôs Michels:

A constituição de oligarquias no seio das múltiplas formas de democracia é um fenômeno orgânico e por consequência uma tendência à qual sucumbe fatalmente toda organização, seja socialista ou mesmo anarquista. [...]

A massa nunca será soberana a não ser de uma forma abstrata. Por isso a pergunta que se faz não é a de saber de que maneira é possível realizar uma democracia ideal. Deve-se, sobretudo, perguntar até que ponto e em que medida a democracia é desejável num momento determinado. $^{299}$

Depreende-se que, a despeito de os partidos terem surgido e se estabelecido indissociáveis da democracia, em função da conquista do sufrágio popular e do aumento das prerrogativas parlamentares, ${ }^{300}$ a construção da teoria elitista para explicá-los mostrou-se acertada e coerente. Esse diagnóstico permanece por algum tempo, até que, no início da década de 1950, os partidos políticos ganham uma releitura pelas mãos de Maurice Duverger, que, em obra clássica, elabora uma teoria geral dos partidos políticos, exercendo forte influência nos estudos acadêmicos elaborados na segunda metade do século XX.

De acordo com Duverger, os partidos políticos nasceram e foram desenvolvidos simultaneamente ao surgimento dos processos eleitorais, sendo

299 MICHELS, Robert. Sociologia dos partidos políticos. Trad. Arthur Chaudon. Brasília: Universidade de Brasília, 1982, p. 226.

300 DUVERGER, Maurice. Op. cit., p. 31. 
caracterizados por um conjunto de indivíduos reunidos por apresentar afinidade de interesses e buscar conquistar o poder político. ${ }^{301}$

Sua análise recai sobre dois tipos de partidos: os partidos de quadros, que haviam se formado em meados do século XIX e tinham, dentre seus membros, intelectuais, autoridades civis e militares, e que conquistaram seu espaço "de cima para baixo”. Os partidos de massa se firmaram a partir de meados do século XX, nas sociedades capitalistas, originando-se da mobilização das classes trabalhadoras, com programas consistentes, unidade ideológica, e vínculo com as bases.

São esses partidos que prosperam nas sociedades democráticas, exatamente por conseguirem atender de forma mais eficaz às condições impostas pela democracia ocidental. A substituição dos partidos de quadro pelos partidos de massa aconteceria progressivamente e de forma natural.

Em relação aos partidos de massa, mais importantes para a presente argumentação, lista o autor seus elementos constitutivos, elencando-os da forma descrita a seguir.

Os partidos de massa possuem uma origem extraparlamentar, oriunda das organizações da sociedade civil. Sua organização interna é rígida, com funções divididas entre seus membros. Assim, enquanto alguns ficam responsáveis pela arregimentação política, outros praticam o ensino da doutrina ideológica, e as lideranças estabelecem as diretrizes principais a serem seguidas à risca, já que a subordinação dos parlamentares ao partido é igualmente uma de suas características fundamentais. A distribuição de poder é centralizada e em âmbito nacional. Como as funções são rigorosamente estabelecidas, a filiação exige compromisso entre membros e partido, o que inclui um sistema de financiamento compartilhado entre o corpo partidário.

O exemplo óbvio de partido de massa, no Brasil, seria o PT, que pode ter sua formação inicial enquadrada na tipologia de Duverger, mas que, progressivamente, reafirma a tese de Michels, transformando-se em uma oligarquia. Houve um afastamento dos grupos de base e um fortalecimento do núcleo central, cujas ideias não

301 Ibidem. 
poderiam ser mais contrariadas, sob pena de expulsão do partido. Os filiados ou simpatizantes passaram a ser mobilizados somente durante os períodos eleitorais, valendo até mesmo receber ajuda financeira por esse trabalho "militante”. A mudança para um partido “profissional-eleitoral” leva à constatação feita por Panebianco: ocorreu a desideologização dos partidos, que se abriram aos grupos de interesse, atendendo a suas demandas e não ao programa ideológico do partido. Esse aburguesamento da elite partidária e o fortalecimento do poder organizativo dos líderes levam ao declínio acentuado da militância política e de base, de modo que a relação entre partido e eleitorado se vê debilitada. ${ }^{302}$

Panebianco foi influenciado pelo trabalho de Sigmund Neumann, o qual relacionou o estudo dos partidos com seus aspectos organizacionais. Os chamados "partidos de representação individual” corresponderiam aos partidos de quadros de Duverger, tendo como foco o atendimento das demandas de grupos sociais específicos e sendo caracterizados por um ambiente de inexpressiva participação política e precária estrutura organizacional.

De outro lado, situavam-se os "partidos de integração social”, que buscavam, como o próprio nome diz, integrar os mais diversos grupos sociais, fazendo valer a voz e os interesses dos representados, por meio de uma estrutura balanceada e bem definida.

Malgrado terem sido tão influentes na década de 1950, essas teorias começam a perder força na década seguinte, e vários questionamentos são feitos a esses modelos partidários.

Nesse sentido, surge o conceito do catch-all-parties, desenvolvido por Kirchheimer. ${ }^{303} \mathrm{O}$ intelectual alemão vai de encontro às hipóteses de Duverger, afirmando que as democracias verão o êxito dos partidos catch-all, no qual ocorre a predominância dos interesses corporativos e cuja profissionalização resulta na dominação política dos membros da cúpula partidária. O apelo feito a grupos diversos

302 PANEBIANCO, Ângelo. Modelos de partido. Organização e poder nos partidos políticos. São Paulo: Martins Fontes, 2005, p. 510-511.

303 KIRCHHEIMER, Otto. The catch-all party. In: MAIR, Peter (Org.). The western European party system. Oxford: Oxford University Press, 1990, p. 50-60. 
por apoio financeiro e eleitoral apenas causa uma diluição das ideologias, que se misturam e perdem suas características originais, ficando sem personalidade.

O que prevalece não é mais formar uma militância ou estruturar um grupo político conscientemente organizado que segue um programa com um plano de governo sólido. Na verdade, isso pode até mesmo representar um grande obstáculo. Afinal, se as atenções se voltam apenas para as urnas e o triunfo eleitoral, é preciso haver flexibilidade operacional e uma militância fácil de ser manipulada. Ganham espaço nesse cenário de competição pelo voto os meios de comunicação de massa.

Mainwaring executa uma análise percuciente sobre os partidos brasileiros, afirmando que eles são “[...] singularmente subdesenvolvidos” ${ }^{304}$ para um país com o nível de modernização como o que o Brasil possui e que conta com quase duas décadas de democracia liberal, estabelecida entre 1946-1964.

A fórmula que o partido encontra para influenciar a escolha de seus candidatos depende do sistema eleitoral adotado e da própria estrutura do partido. No caso de um sistema eleitoral com lista fechada, os partidos tanto escolhem os candidatos como ordenam previamente a lista dos nomes que assumirão as cadeiras parlamentares.

Observando as regras do sistema eleitoral brasileiro - proporcional e com lista aberta -, o autor infere que ele impulsiona uma atuação individual do candidato. Embora a lista aberta proporcione maior liberdade de escolha, pode ocorrer de um eleitor eleger um candidato que leva com ele para o Parlamento outros representantes que não passariam pelo crivo do eleitor de outra forma.

A campanha eleitoral se dá igualmente entre candidatos, e não entre partidos, isto é, as campanhas são individualizadas e dependem cada vez mais das pesquisas de opinião, as quais apontam quem deveria figurar como candidato, que posição ele deve ter sobre assuntos polêmicos, ou até se deve manter ou não a relação matrimonial. É como se os representantes pudessem atuar independentemente de um programa partidário, desde que estejam atentos aos meios de comunicação.

304 MAINWARING, Scott. Políticos, partidos e sistemas eleitorais: o Brasil numa perspectiva comparada. Trad. Otacílio F. Nunes Jr. Novos Estudos Cebrap, São Paulo, n. 29, p. 34-58, 1991. 
Além disso, a legislação brasileira permite a existência de um grande número de partidos e de candidatos, o que dificulta a escolha, por parte do eleitorado, que fequentemente decide na hora em quem votar e pouco tempo depois já não se lembra mais em quem votou.

Ao mesmo tempo, a legislação eleitoral é permissiva, tanto que as campanhas presidenciais já estão em andamento, mas as multas cobradas são irrisórias e não impedem os candidatos de iniciar suas campanhas.

Depois de eleitos os candidatos, os partidos se encaixam na categoria dos catch-all, formando bancadas com ideologias díspares e com pouca influência sobre seus parlamentares, as quais não correspondem necessariamente às diretrizes do partido.

O sistema partidário conta com as elites políticas e os líderes estatais a dominar os partidos para promover seus interesses, e a baixa institucionalização gera as dificuldades encontradas pelo Presidente da República em organizar apoio político, por intermédio dos canais partidários.

A fragilidade dos partidos acarreta a fragilidade da democracia, pois os instrumentos de representação não executam seu papel como deveriam, estimulando uma representação individualista e clientelista, e dificultando a accountability que deveria ser obtida pela atuação partidária, ${ }^{305}$ ao verificar se os representantes estão cumprindo as metas estabelecidas e atendendo aos anseios daqueles que neles votaram. O papel da accountability deve ser do partido, o qual precisa se depurar para participar do quadro competitivo das eleições da forma mais transparente e coerente possível.

Há de se destacar a influência da mídia sobre a democracia, que vem sendo observada em vários estudos acadêmicos, nas últimas décadas, e que apresenta novas possibilidades com as novas tecnologias de comunicação.

\footnotetext{
305 A accountability pode ocorrer quando o eleitor vota na expectativa de que o representante agirá para alcançar os desejos e aspirações da população, ou quando o representante seleciona um conjunto de políticas necessárias para a reeleição. Os eleitores devem avaliar corretamente os candidatos e o conjunto de políticas públicas que ele propõe. Para tanto, é fundamental que o eleitor tenha acesso a todas as informações necessárias sobre os candidatos e os partidos, e que tenha capacidade para efetuar uma avaliação. MANIN, B.; PRZEWORSKI, A.; STOKES, S. Democracy, accountability and representation. Nova York: Cambridge University Press, 1999.
} 
Sartori, ${ }^{306}$ por exemplo, há muito tratou dos efeitos perniciosos da videopolítica nas eleições. A expressão, que denota a influência do vídeo (aqui entendido em sentido amplo, sendo “[...] a superfície na qual vemos” ${ }^{307}$ ) no processo político, nota que os meios de comunicação transformam o debate político em um verdadeiro espetáculo midiático, um show business que envolve muito dinheiro e pouca informação. Menciona os danos causados pela televisão, que desestimulou o hábito da leitura, interferindo na qualidade da educação e do debate político, o que, em última instância, afetará a própria participação política e a possibilidade de formação de opiniões consistentes e bem fundamentadas. Para o autor,

[...] é incontestável que a televisão é um formidável formador de opinião. Hoje, o povo soberano "opina” sobretudo em virtude da forma com que a televisão o induz a opinar. Por isso o poder do vídeo, ao dirigir a opinião pública, coloca-se realmente no centro de todos os processos da política contemporânea.

[...] a televisão condiciona de modo pesado o processo eleitoral, quer na escolha do candidatos, quer na forma deles conduzirem a disputa eleitoral. ${ }^{308}$

Bourdieu, na mesma linha de análise, aborda a influência dos índices de audiência sobre a programação televisiva, que faz com que a lógica comercial determine as produções culturais e os diversos programas televisivos. O papel da televisão é dramatizar os fatos, dar ênfase a fatos sensacionalistas, banalizar a informação, sem analisar aspectos relevantes dos acontecimentos. ${ }^{309} \mathrm{O}$ mesmo acontece com as campanhas eleitorais, que privilegiam o marketing político, as piadas, jingles, aparência dos candidatos - e não os programas do partido.

Um exemplo desse fenômeno foi a eleição do candidato Tiririca, nas eleições de 2010. Houve aqui um momento de criação, evolução e obtenção de liderança, em que o candidato se destacou por seu carisma, ou por sua ingenuidade, e conseguiu o destaque. Contudo, pode o partido eleger alguém para alavancar-se ao poder? Ou essa

\footnotetext{
306 SARTORI, Giovanni. Homo videns: televisão e pós-pensamento. Trad. Antonio Angonese. Bauru: EDUSC, 2001.

307 SARTORI, Giovani. Op. cit., p. 50.

308 SARTORI, Giovani. Op. cit., p. 51.

309 A televisão pode “[...] ocultar mostrando, mostrando uma coisa diferente do que seria preciso mostrar caso se fizesse o que supostamente se faz, isto é, informar [...]” BOURDIEU, Pierre. Sobre a televisão. Trad. Maria Lúcia Machado. Rio de Janeiro: Zahar, 1997, p. 24.
} 
tática é ofensiva ao eleitorado? Em tendo obtido a expressiva votação que recebeu, parece que o eleitorado se identificou com a curiosidade de Tiririca sobre o que acontece na Câmara. O problema é que o eleitorado é influenciado pelo circo midiático, pelo qual a atividade política se realiza na dimensão pública instituída pela televisão, rádio e, atualmente, Internet. O processo de espetacularização esvazia as propostas e valoriza a imagem, favorecendo candidatos que podem investir na construção de seu perfil, na mídia. $^{310}$

Manin radicaliza o debate a ponto de afirmar que a mídia substitui os partidos. Se, antes, a intermediação entre representantes e representados era feita pelos partidos, agora os candidatos conseguem se libertar da estrutura partidária, dispendiosa e complexa, para adotar um novo modelo, a democracia de públicos (audience democracy), com a emergência da mídia a costurar a relação entre representantes e representados. $^{311}$

Essa metamorfose da representação aponta para uma mudança paradigmática: o eleitor deixa de votar no partido ou em uma ideologia e passa a votar no candidato, sendo influenciado pelos meios de comunicação, com toda sua estrutura técnica e de amplo alcance de público.

As preferências dos candidatos acerca das questões políticas expressam-se cada vez mais frequentemente por intermédio das pesquisas de opinião e das organizações que visam fomentar um objetivo particular, mas não têm a intenção de tornar governo. [...] a arena política vem sendo progressivamente dominada por fatores técnicos que os cidadãos não dominam. Os políticos chegam ao poder por causa de suas aptidões no uso dos meios de comunicação de massa, não porque estejam próximos ouse assemelham aos seus eleitores. ${ }^{312}$

310 Ver também a obra de Schwartzenberg (1977), que aprofunda a relação entre espetáculo, política e mídia, afirmando que "[...] o poder se transformou em espetáculo. [...] Em política, descamba-se para a contemplação mórbida. O cidadão encontra prazer na simples visão dos dirigentes políticos que atuam diante de seus olhos. Sua satisfação já não está na ação, e sim na contemplação passiva”. SCHWARTZENBERG, Roger-Gérard. O Estado espetáculo: ensaio contra o star system em política. São Paulo: Círculo do Livro, 1977, p. 326.

311 MANIN, Bernard. As metamorfoses do governo representativo. Revista Brasileira de Ciências Sociais, São Paulo, n. 29, ano 10, out. 1995.

312 MANIN, Bernard. Op. cit., p. 1. 
Por fim, antes de serem feitas mais considerações em capítulo específico sobre o papel dos meios de comunicação na intermediação política da sociedade, cabe lembrar a interpretação feita por Castells, para quem a crise não é de representação, mas de legitimidade, em um jogo perigoso para o fortalecimento democrático, pois os cidadãos desarticulados não induzem novas formas de transformação social e não buscam a reconstrução de seus objetivos. Ao mesmo tempo, eles não se sentem representados por aqueles que elegeram. É um impasse que necessita de urgente mudança. O autor conclama a sociedade a tomar um rumo diferente do que existe hoje, com abstenção eleitoral e falta de interesse em questões políticas, o que pode ser feito com o auxílio das mídias eletrônicas:

As novas condições institucionais, culturais e tecnológicas do exercício democrático tornaram obsoletos o sistema partidário existente e o atual regime de concorrência política como mecanismos adequados de representatividade política na sociedade em rede. Isso tem levado à volatilidade eleitoral, ao desaparecimento gradativo dos partidos e à importância decisiva da mídia nos processos eleitorais. ${ }^{313}$

O ideal democrático tem sido defendido pelas nações ocidentais, ao longo da história contemporânea, mas o descrédito nos partidos e no parlamento é grave. As demandas sociais não são atendidas, e o que se vê é a eterna fusão entre o público e o privado, ${ }^{314}$ na qual os políticos veem a coisa pública como sua. Dessa maneira, em alguns momentos, a própria democracia é, infelizmente, rechaçada. As investigações feitas pelo instituto latino-americano chamado Latinobarómetro, desde 1996, devem ser verificadas com atenção. Realizando importantes pesquisas em todos os países da América Latina, nas últimas décadas, fica demonstrada a falta de credibilidade na democracia, com as pesquisas indicando que, no Brasil, no ano de 2010, por exemplo, a insatisfação com o regime chegava a $85 \%$ ! $^{315}$

313 CASTELLS, Manuel. O poder da identidade. Trad. Klauss Brandini Gerhardt. Rio de Janeiro: Paz e Terra, 2001, p. 407-408.

314 Uma questão problemática na construção da comunidade política de nosso país, já dissecada por tantos historiadores, como Holanda, que enfatiza ser essa "[...] invasão do público pelo privado, do Estado pela família”, uma condição prévia para a constituição de uma ordem moderna brasileira. HOLLANDA, Sérgio Buarque. Raízes do Brasil. São Paulo: Companhia das Letras, 1995, p. 82.

315 O site mencionado é rico em suas análises e gráficos, oferecendo amplos painéis sobre a democracia, já que as perguntas giram em torno do apoio à democracia, satisfação com a democracia, seus significados e aspectos mais importantes. Disponível em: <http://www.latinobarometro.org>. Acesso em: 03 abr. 2013. 
Essa postura em relação à democracia talvez esteja ligada aos casos rotineiros de corrupção política e desvio de verba pública, até mais do que com os princípios democráticos balizadores da igualdade e liberdade, ainda prestigiados. O cenário, de qualquer forma, é preocupante, pois a democracia é um regime que exige a contribuição de todos para sua construção e sedimentação, ou seja, exige

[o] reconhecimento de que todos devem participar do poder. $\mathrm{O}$ reconhecimento de que, sendo todos os homens racionais, a razão de cada um pode trazer uma contribuição para a obra comum, o que importa em ouvir, compreender e ponderar. O reconhecimento de que todos têm direito de saber por que se fazem certas coisas, como o de discordar do que se faz. Tolerância, transigência, respeito à oposição, diálogo, participação, todas essas virtudes defluem do respeito ao próximo. ${ }^{316}$

Com efeito, todos esses valores precisam ser constantemente relembrados e reforçados, para que esta e as próximas sociedades construam ambientes cada vez mais democráticos. O estímulo à participação eleitoral é, por conseguinte, imprescindível para seu alcance.

\subsubsection{A natureza jurídica dos partidos políticos}

Na trajetória constitucional dos partidos políticos, afirma-se, sem dúvida, que eles foram inicialmente proscritos, com a primeira menção a eles aparecendo apenas na Constituição de 1934. A referência, entretanto, foi pontual, relacionada à perda de cargo pelo funcionário público, caso ele usasse de sua autoridade para beneficiar um partido político. Depois disso, a Constituição de 1937 não tratou do tema e “[...] formalmente, a Constituição de 1946 foi a primeira a preocupar-se realmente com o fenômeno partidário,” ${ }^{317}$ ensejando a consagração da democracia pelos partidos. Sartori, ${ }^{318}$ aliás,

316 FERREIRA FILHO, Manuel Gonçalves. Sete vezes democracia. São Paulo: Convívio, 1977, p. 25.

317 JEHÁ. Pedro Rubez. Os partidos políticos em cenário eleitoral. In: CAGGIANO, Monica Herman S. (Coord.). Direito eleitoral em debate: estudos em homenagem a Cláudio Lembo. São Paulo: Saraiva, 2013, p. 105. De se destacar a observação de Poletti, no sentido de que a falta de menção aos partidos políticos nas primeiras constituições também é notada na constituição americana e na francesa, tanto a do século XIX como a de 1946. Mesmo na Inglaterra, onde surgiram, por não haver Constituição escrita, eles não são disciplinados por lei. Foi a Constituição da Itália, no ano de 1846, a primeira na Europa a abordar o instituto. Cf. POLETTI, Ronaldo. O partido político na Constituição. Revista de Informação Legislativa, Brasília, v. 24, n. 93, p. 106, jan./mar. 1987.

318 Na obra publicada em 1976, o autor afirma: “Ainda hoje, na maioria dos países, os partidos continuam, juridicamente, associações privadas sem reconhecimento constitucional. Entre as poucas exceções notáveis estão a Lei Fundamental de Bonn e a Constituição Francesa de 1958”. SARTORI, Giovanni. Partidos e sistemas partidários. Brasília: Editora Universidade de Brasília, 1982, p 34. 
assevera que o partido político só ganhou definição legal depois da Segunda Guerra Mundial.

O partido político já foi considerado pessoa jurídica de direito público. O Código Eleitoral, em seu art. 132, assim dispunha: “Os partidos políticos são pessoas de direito público interno.” Eram, pois, instituições com função definida, sujeitos de direitos e deveres, e caminhavam paralelamente ao Estado. ${ }^{319}$ Salienta Ferreira Filho: “Tal posição ajusta-se ao papel dos partidos. [...] É aliás, a única que não entra em conflito com a realidade subjacente. De fato, o partido deve ser considerado como uma instituição.”320

A CF/88 deixou livre a criação de partidos, os quais passaram a ter a natureza de pessoa jurídica de direito privado, tornando-se uma associação que possui o monopólio da candidatura. Destarte, o monopólio da candidatura, que é uma função pública, foi entregue em mãos a uma instituição privada com financiamento, o que parece paradoxal.

As normas do art. 17 da Constituição Federal, com exceção de seu $\S 3^{\circ}$ (acesso dos partidos políticos ao fundo partidário e acesso gratuito ao rádio e à televisão), são de natureza programática e prescindem de regulamentação, tendo aplicabilidade imediata. Dentre essas normas, inclui-se a do $\S 2^{\circ}$, que estipula: “Os partidos políticos, após adquirirem personalidade jurídica, na forma da lei civil, registrarão seus estatutos no Tribunal Superior Eleitoral.” Fica determinado pela Carta Magna, nesse sentido, que a aquisição de personalidade jurídica pelos partidos obedece aos dispositivos do Código Civil e da lei dos registros públicos - Lei 6.015/73, sendo que o registro junto ao Tribunal Superior Eleitoral confere aos partidos políticos capacidade jurídica.

Com isso, a Constituição de 1988 trouxe mudanças ao tema que se coadunam ao seu capítulo 1, em especial seu inciso XVII, segundo o qual “[...] é plena a liberdade de associação para fins lícitos, vedada a de caráter paramilitar”. Os partidos políticos

\footnotetext{
319 E, se ainda o fosse, talvez fizesse sentido hoje a defesa do financiamento público das campanhas políticas.

320 FERREIRA FILHO, Manoel Gonçalves. Os partidos políticos nas constituições democráticas: o estatuto constitucional dos partidos políticos no Brasil, na Itália, na Alemanha e na França. Revista Brasileira de Estudos Políticos, Belo Horizonte, 1966, p. 71.
} 
podem se associar livremente, dentro dos balizamentos propostos em lei, como o número de fundadores, por exemplo. São associações autônomas, que dependem apenas da vontade de seus interessados, para que possam surgir.

Conclui-se que os partidos políticos são pessoas de direito privado, sujeitos à lei civil e ao registro no cartório civil. ${ }^{321}$

Assentado está pelo TSE que a Lei Orgânica dos Partidos Políticos foi recepcionada pela Constituição Federal naquilo que não haja confronto. Assim, a recepção foi parcial, já que o art. $2^{\circ}$ da referida lei tratava da natureza jurídica de direito público interno dos partidos, o que afronta a orientação da Carta de 1988.

Essas associações privadas defendem interesses particulares atinentes a seus membros, mas também exercem funções benéficas para o Estado. Não são órgãos estatais, nem agem em nome do Estado, sendo considerados órgãos auxiliares do Estado. Acentua o eminente Fávila Ribeiro que “[...] não pode o partido ser considerado como órgão estatal, por ser um sujeito, próprio de direitos e obrigações, em decorrência de sua personificação jurídica. Age em seu próprio nome no exercício de atividades públicas”. 322

A Constituição de 1988 sedimentou essa posição. De fato, os partidos políticos não são pessoas jurídicas de direito público, nem associações civis comuns. Representam um meio institucional de cumprimento de princípios constitucionais e devem ser preservados no sistema representativo pela expressão da vontade popular, traduzida no sufrágio. A propósito, Canotilho elucida, sobre os partidos políticos, que

[...] a sua função de mediação política - organização e influência na formação do governo - conduz a reconhecer-se-lhes uma qualidade jurídico-constitucional que distingue as associações partidárias das simples associações privadas. Como elementos funcionais de uma ordem constitucional, os partidos situam-se no ponto nevrálgico em

321 A escolha do constituinte pátrio seguiu o modelo português, explica Bastos. E reforça: “[...] não subsistirem dúvidas quanto a serem os partidos políticos dotados de personalidade jurídica e sua natureza ser de direito privado, uma vez que são constituídos na forma da lei civil.” BASTOS, Celso Ribeiro. Comentários à Constituição do Brasil. São Paulo: Saraiva, 2004.

322 RIBEIRO, Fávila. Direito Eleitoral, p. 234. 
que convergem o poder do Estado juridicamente sancionado e o poder da sociedade politicamente legitimado. ${ }^{323}$

Por conseguinte, os partidos políticos são associações organizadas pela sociedade em sede democrática para a propagação de ideias, que serão concretizadas pela ação política. Visam a alcançar o poder, para, em princípio, colocar em prática seu plano de governo pela atuação de seus candidatos eleitos, e não exercem poder público. O Estado não tem a reserva do controle da vida partidária.

Vale dizer que eles são obrigados a prestar contas à Justiça Eleitoral, na tentativa de coibir o abuso do poder econômico, o que prejudica gravemente o processo eleitoral.

A Constituição Federal de 1988, além de alterar a natureza política dos partidos políticos, afirmou a plena autonomia dessas pessoas jurídicas de direito privado, assegurando-lhes auto-organização e imunidade nas questões interna corporis.

\subsubsection{Criação, registro, estrutura e extinção dos partidos políticos}

Em ambientes democráticos, como aduz Panebianco, ${ }^{324}$ os partidos políticos atuam no centro da arena eleitoral, exercendo uma atividade de competição pela disputa de votos e conquista do poder político. Conforme frisado anteriormente, não há eleição sem partido político. Por isso, mostra-se fundamental o estudo de sua criação, registro, estrutura e extinção, que terão como base a análise de alguns dos já referidos pilares do Direito Eleitoral: Constituição Federal de 1988, Código Eleitoral (Lei no 4.737/45), Lei dos Partidos Políticos (Lei ${ }^{\circ}$ 9.096/95) e Lei das Eleições (Lei n 9.504/97), que discorrem sobre os procedimentos que legitimam as eleições e sobre os órgãos regularmente instituídos para executá-las.

A Constituição da República Federativa do Brasil estabelece, em seu art. 17: “É livre a criação, fusão, incorporação e extinção de partidos políticos, resguardados a soberania nacional, o regime democrático, o pluripartidarismo e os direitos fundamentais da pessoa humana”.

\footnotetext{
${ }^{323}$ CANOTILHO, J.J. Gomes. Direito constitucional. Coimbra: Almedina, 1991, p. 453.

324 PANEBIANCO, Ângelo. Op. cit., p. 11.
} 
A previsão aponta para a liberdade na criação dos partidos, resguardados os valores ali destacados. Aos partidos políticos é assegurada “[...] autonomia para definir sua estrutura interna, organização e funcionamento, devendo seus estatutos estabelecer normas de fidelidade e disciplina partidárias”, de acordo com o art. 17, § $1^{\circ}$, da CF/88. Essa autonomia organizatória, por evidente, ocorre dentro de parâmetros democráticos, sem poder afrontar os valores aos quais está submetida.

A valorização dos partidos trazida pela visão inovadora dos constituintes de 1988 exigia uma norma que atendesse aos princípios desse art. 17. Por conta disso, foi instituída a Lei n ${ }^{\circ}$ 9.096/95, que, em seus artigos $8^{\circ}$ e $9^{\circ}$, trata do processo de criação do partido político; foi ainda editada a Res.-TSE $n^{0} 19.406 / 95$, revogada pela Res.-TSE $n^{\circ}$ 23.282/2010, que discorrem sobre a fundação, a organização, o funcionamento e a extinção dos partidos políticos.

A Lei 9.096/95 lista, em seus artigos $8^{\circ}$ e $9^{\circ}$, todos os documentos, requerimentos e certidões exigidos para o surgimento de um novo partido. Para ser criado, o partido político precisa ter representação nacional, sendo demonstrado que ele possui $0,1 \%$ dos votos válidos em nível municipal, além de $0,1 \%$ dos votos válidos em âmbito estadual e 0,5\% dos votos válidos obtidos em nível federal, o que representa, atualmente, 492.000 assinaturas. ${ }^{325}$ Esses votos têm que estar distribuídos entre um terço dos Estados, ou seja, entre nove Estados da federação.

Em assim sendo, o grupo que pretende criar um novo partido deve colher as assinaturas de seus apoiadores, e os cartórios atuarão na certificação dessas assinaturas, verificando se não há caso de duplicidade, se os eleitores estão devidamente registrados em seus cartórios eleitorais, se as assinaturas são verdadeiras, dentre outros requisitos formais. De posse dessas certidões, os Tribunais Regionais Eleitorais fazem a consolidação dos apoios, verificando se eles atendem ao número legalmente exigido.

Todo esse processo está devidamente sujeito aos princípios do contraditório e da ampla defesa.

\footnotetext{
325 Disponível em: <http://www.tse.jus.br>. Acesso em: 25 set. 2013.
} 
A Lei $n^{0}$ 9.096/95 baniu a possibilidade do registro provisório. Para registrar um partido político, o interessado tem que cumprir todos os requisitos estabelecidos na Lei dos Partidos Políticos e na Res.-TSE n 23.282/2010. Assim, como dispõe o art. $8^{\circ}$ daquela lei, devem reunir-se os fundadores, em número nunca inferior a cento e um, com domicílio eleitoral em, no mínimo, um terço dos Estados, para elaborar o programa e o estatuto do partido, que deverá ser publicado no Diário Oficial. Nessa mesma reunião, serão eleitos, em caráter provisório, os dirigentes nacionais, que vão organizar o partido.

Após a publicação no Diário Oficial, promove-se o registro do partido no Cartório de Registro Civil das Pessoas Jurídicas da Capital Federal. O registro no cartório é o momento em que o partido em formação adquire personalidade jurídica e comunica aos tribunais regionais o nome dos representantes que serão responsáveis pela entrega das listas do apoiamento mínimo de eleitores nos cartórios eleitorais.

O apoiamento mínimo consiste no colhimento das assinaturas correspondentes, no mínimo, a meio por cento $(0,5 \%)$ dos votos válidos, dados na última eleição geral para a Câmara dos Deputados, não computados os brancos e os nulos, distribuídas em pelo menos nove Estados. Além dessa exigência, em cada Estado, deve-se atender ao mínimo de um décimo por cento $(0,1 \%)$ do eleitorado.

Em seguida, o partido deverá constituir, definitivamente, na forma de seu estatuto, os órgãos diretivos municipais e regionais, registrando-os nos tribunais regionais eleitorais de, no mínimo, nove unidades da federação.

Registrados os órgãos partidários municipais e regionais nos tribunais regionais, deverá ser solicitado o registro do programa, do estatuto e do órgão de direção nacional no TSE, última fase do processo de registro. É o estatuto que contém as regras de fidelidade e disciplina partidárias.

Determina o art. 18 da Lei $\mathrm{n}^{0}$ 9.096/95: "Para concorrer a cargo eletivo o eleitor deve estar filiado ao partido pelo menos um ano antes da data fixada para as eleições, majoritárias ou proporcionais.” E o art. 17, $\S 1^{\circ}$ da CF/88 afirma que os estatutos dos partidos “devem estabelecer normas de disciplina e fidelidade partidária.” 
No Brasil, os partidos políticos possuem o monopólio das candidaturas, e o valor constitucional desse instituto ganhou relevo:

Se considerarmos e exigência de filiação partidária como condição de elegibilidade e a participação do voto de legenda na eleição do candidato, tendo em vista o modelo eleitoral proporcional adotado para as eleições parlamentares, parece certo que a permanência do parlamentar na legenda pela qual foi eleito torna-se condição imprescindível para a manutenção do próprio mandato. ${ }^{326}$

A partir do deferimento, o partido garante exclusividade da denominação e da sigla, do número de legenda e de seus símbolos, além de tornar-se apto a receber recursos do fundo partidário, a ter acesso gratuito ao rádio e à televisão e a participar do processo eleitoral.

Recentemente, a Presidente da República sancionou a Lei no 12.875, de 30 de outubro de 2013, que modifica regras sobre distribuição dos fundos partidários e tempo de propaganda, provocando alterações na Lei no 9.96/95 e na Lei nº 9.504/97.

A nova lei prevê que $5 \%$ do fundo partidário serão divididos igualmente e distribuídos para todas as legendas. Os 95\% restantes serão distribuídos de forma proporcional aos votos obtidos para deputado na Câmara Federal, sendo desconsideradas as mudanças decorrentes de filiação partidária. Assim, os deputados que mudarem de partido não podem levar os votos com eles, pois isso aumentaria o repasse do fundo partidário.

Quanto à propaganda eleitoral, a mudança é em relação à distribuição de dois terços do tempo, também de modo proporcional ao número de deputados federais eleitos pelo partido, na última eleição. O outro terço é distribuído uniformemente.

Com isso, os novos partidos criados no ano de 2013 concorrerão nas próximas eleições com tempo mínimo de televisão para cada legenda e com percentual menor de

\footnotetext{
326 MENDES, Gilmar Ferreira; COELHO, Inocêncio Mártires; BRANCO, Paulo Gustavo Gonet. Curso de direito constitucional. 4. ed. São Paulo: Saraiva, 2009, p. 812. A troca de partido, portanto, implica extinção de mandato, a não ser em caso de incorporação ou fusão do partido, criação de novo partido, mudança substancial ou desvio reiterado do programa partidário e grave discriminação pessoal, como estabelece a Resolução do TSE n 22.610, Rel. Min. Cezar Peluso, de 25 de out. de 2007.
} 
fundo partidário, o que pode lhes causar problemas no pleito, pois recursos financeiros e midiáticos são sempre ambicionados, por aumentarem as chances de vitória eleitoral.

Os dois novos partidos criados - Solidariedade, encabeçado pelo deputado federal Paulo Pereira da Silva (PDT-SP), e PROS, Partido Republicano da Ordem Social, montado pelo ex-vereador Eurípedes de Macedo Jr. - fizeram com o quadro político brasileiro passasse a contabilizar 32 legendas. A Rede, de Marina Silva, não conseguiu aprovação, por ter o TSE entendido que o partido não teria conseguido o número necessário de assinaturas exigidas para sua criação. ${ }^{327}$

Não obstante a previsão da livre criação de partidos, cabe indagar até que ponto deve haver essa proliferação de siglas, se há alguma diferença ideológica em sua constituição e se isso beneficia o modelo democrático.

É difícil crer que cada um dos 32 partidos hoje presentes no cenário eleitoral brasileiro represente veios ideológicos diferenciados, ou ainda saber qual o interesse coletivo que cada um deles visa a defender. A falta de ideologias definidas demonstra que as legendas são criadas para satisfazer o interesse das lideranças.

Isso sem considerar que o excesso de siglas atrapalha o eleitor, no momento de fazer suas escolhas. Se as propostas são tão similares, como distinguir uma da outra? Essa situação prejudica o debate de ideias e centraliza o voto na pessoa do candidato, o que não contribui para o incremento da democracia. Dificulta, ademais, a responsabilização governamental, além de gerar dúvidas sobre o financiamento das campanhas. Os partidos deveriam ser a instituição capaz de realizar a mediação responsabilizadora entre eleitores, assegurando a previsibilidade do governo e do comportamento legislativo, mas, com essa proliferação de legendas, o que acontece é apenas o aumento do descrédito nessas instituições. Por isso, esse multipartidarismo deve ser combatido.

327 No julgamento, seis dos sete ministros do TSE negaram o pedido feito pela Rede Sustentabilidade, porque 95 mil assinaturas de eleitores foram descartadas pelos cartórios eleitorais, e o TSE entendeu que a autenticidade de assinatura era um ônus do partido e não do cartório. O voto vencido do Min. Gilmar Mendes se posicionou no seguinte sentido: "Essa contagem de assinaturas e verificação de firma é o quadro de um Brasil do passado. Isso nos obriga a dizer: vamos atualizar essa justiça, de fato informatizar cartórios.” TSE - Acórdão - Registro de partido político nº594-54.2013.6.00.0000. Min. Rel. Laurita Vaz. 
Assim que criado o partido, ele tem autonomia para fixar as regras de condução de suas convenções, podendo estabelecer prazos superiores aos descritos na lei para que o filiado concorra às eleições.

A Lei Orgânica dos Partidos Políticos define o formato geral da estrutura partidária no país. Há necessidade de criação de órgãos de decisão em todas as instâncias, nacional, estadual e municipal. Cabe a esses órgãos cuidar das decisões referentes à organização dos partidos, escolha dos dirigentes, seleção de quadros a cargos eletivos, além das típicas funções administrativas e de infraestrutura. As principais decisões giram em torno da escolha das candidaturas majoritárias, formação das listas partidárias e coligações. ${ }^{328}$

As coligações decorrem da união de dois ou mais partidos que apresentam conjuntamente seus candidatos para a eleição. Pode ser formada para eleições majoritárias ou proporcionais.

No Brasil, a presença do grande número de partidos que participam do processo eleitoral faz com que muitos deles representem meras siglas, sem representatividade, os quais se aproveitam das coligações para participar das barganhas políticas. O fato de o eleitor brasileiro poder votar na legenda também pode fazer com que o voto do eleitor não conduza ao parlamento um candidato de seu partido, mas um candidato do partido coligado. Isso provoca críticas às coligações, porque elas ensejam uma valorização descabida das minorias, que, muitas vezes, emprestam seus nomes com intenções de obter vantagens questionáveis para o partido.

Por outro lado, no entender de Silva, que se apoia em Meyer, todas as partes possuem interesse em chegar ao poder, seja o partido mais forte, seja o mais fraco, seja até o eleitor, que deseja ver seu partido e seus candidatos no parlamento. Sabendo que um precisa do outro e que essa união é admitida pelo jogo eleitoral, a coalização deixaria de ser vista de forma tão perniciosa. Nesse sentido,

328 BRAGA, Maria do Socorro Sousa. Organizações partidárias e seleção de candidatos no estado de São Paulo. Disponível em: <http://www.scielo.br/scielo.php?script=sci_arttext\&pid=S010462762008000200008>. Acesso em: 24 nov. 2013. 
[tanto] os eleitores dos grandes partidos, tanto quanto os eleitores dos dois grandes partidos típicos de sistemas majoritários querem que seus partidos governem , o que acontecerá mesmo que haja a necessidade de coalizão com pequenos partidos. [...] Já os eleitores dos pequenos partidos sabem, de antemão, que somente fazendo parte de alguma coalizão poderão eles participar do poder. ${ }^{329}$

Parece, todavia, que as coalizações, da maneira como conduzidas, têm reiteradamente se afastado da matriz democrática. As minorias não são, necessariamente, menos eficientes. Contudo, o que se vê são as minorias tendo seu poder imensamente reduzido, quando não anulado. E a maioria, por se saber pertencente a um sistema multipartidário que depende do apoio das mais diversas correntes, dentro do Congresso, promove articulações de toda sorte, distanciando-se frequentemente das propostas de campanha. Com tudo isso, obviamente, a vontade do cidadão é desvirtuada, o que prejudica a democracia.

Por fim, o partido político pode ser extinto por iniciativa própria, mediante deliberação de seus membros, conforme o previsto no estatuto. Além disso, o partido pode passar por um processo de fusão, que ocorre quando dois ou mais partidos políticos se unem sob um novo estatuto, ou por um processo de incorporação, no caso de uma agremiação partidária adotar o estatuto e programa de outra agremiação. Todas essas regras estão disciplinadas no capítulo VI da Lei 9.095/95, composto dos artigos 27,28 e 29.

\subsubsection{O princípio do pluralismo e a atuação dos partidos políticos}

A democracia contemporânea timbrou o termo pluralismo.

O pluralismo pode apresentar várias abordagens; do ponto de vista histórico, ${ }^{330}$ é quase um consenso associar suas raízes analíticas à teoria dos corpos intermediários de Montesquieu. ${ }^{331}$ Confirma Nicola Matteucci que o pluralismo tem suas origens

329 SILVA, Luis Virgílio Afonso da. Op. cit., p. 142.

330 Huntington explica que a sociedade ocidental tem sido marcadamente pluralista, em toda sua história, desde os grupos autônomos que se firmavam sem ter relação de sangue ou de casamento, passando pelos grupos surgidos nas ordens monásticas, os quais se expandiram para o pluralismo associativo, suplementado pelo pluralismo de classes. "O pluralismo social logo levou ao surgimento de assembleias, parlamentos e outras instituições para representar os interesses da aristocracia, do clero, dos comerciantes e outros grupos. Esses órgãos proporcionavam formas de representação que, no 
[...] na defesa que Montesquieu faz dos corpos intermediários, como elementos de mediação política entre o indivíduo e Estado, ou na exaltação feita por Tocqueville das associações livres, consideradas como as únicas capazes de tornar o cidadão apto a se defender da maioria soberana e onipotente. ${ }^{332}$

Assis Brasil compreendeu de forma clara a importância do constitucionalismo e do pluralismo político para a democracia, ${ }^{333}$ abordando, no início de sua obra Democracia representativa, o conceito de liberdade como autonomia do cidadão em participar das decisões políticas, decidindo, dessa forma, seu destino.

O Estado democrático contemporâneo é um Estado de partidos. ${ }^{334}$ Os partidos políticos devem retratar vários segmentos da sociedade, promovendo o enquadramento dos eleitos e a educação política do eleitor. O partido robusto tem o monopólio das eleições e da cadeia parlamentar.

O vínculo entre pluralismo e democracia é forte. Este último reivindica a ampla participação nas decisões coletivas, porém, não garante a ampliação da atuação dos diversos grupos intermediários de poder. É o pluralismo que redefine constantemente as relações entre Estado e sociedade civil, ao reconhecer a legitimidade da diversidade e ao criar mecanismos de regulação da ação do Estado, no que tange à proteção social. ${ }^{335}$

curso do processo de modernização, evoluíram para as instituições da democracia moderna. Em alguns casos, esses órgãos foram abolidos ou seus poderes ficaram muito limitados durante o período do Absolutismo. Contudo, mesmo quando isso aconteceu, eles puderam, como na França, ser ressuscitados para ampliar o meio para uma participação política ampliada. Nenhuma outra civilização contemporânea tem um legado comparável de corpos representativos que exista há um milênio.” HUNTINGTON, Samuel. O choque de civilizações e a recomposição da ordem mundial. Rio de Janeiro: Objetiva, 1997, p. 85.

331 Montesquieu é usualmente considerado como um dos precursores do pensamento pluralista no âmbito da política, já que procura explicar a ineficiência do absolutismo e propõe um governo com liberdade e autonomia, no qual os poderes se controlam mutuamente. Cf. MONTESQUIEU, Op. cit.

332 MATTEUCCI, Nicola. Verbete: Soberania. In: BOBBIO, Norberto; MATTEUCI, Nicola; PASQUINO, Gianfranco. Dicionário de Política. Brasília: UnB, 1986, p. 1186.

333 ASSIS BRASIL, Joaquim Francisco. Op. cit. Livro I, cap. I, p. 89-101.

334 Nesse sentido, ver a obra de Kelsen, que já afirmava: "Só a ilusão ou a hipocrisia pode acreditar que a democracia seja possível sem partidos políticos.” KELSEN, Hans. A democracia. Op. cit. p. 40. Ou, ainda, Ferreira Filho: "Os partidos são, pois, meios indispensáveis de formação da democracia.” FERREIRA FILHO, Manoel Gonçalves. Os partidos políticos nas constituições democráticas. Belo Horizonte: Revista Brasileira de Estudos Políticos, 1966, p. 57.

335 Kelsen afirma que “[...] a participação no governo, ou seja, na criação e aplicação das normas gerais e individuais da ordem social que constitui a comunidade deve ser vista como a característica essencial da democracia.” KELSEN, Hans. Op. cit., p. 142. A participação política (mais próxima ao 
Aprofunda o tema Bobbio, ${ }^{336}$ ao asseverar que “[...] a teoria democrática e a teoria pluralista têm em comum o fato de serem duas propostas diversas, mas não incompatíveis (ao contrário são convergentes e complementares) contra o abuso do poder. ${ }^{337}$ Para a democracia, o fundamento de validade do poder é a vontade popular. E o pluralismo permite a disseminação do poder entre as várias instâncias sociais. Na democracia, as liberdades individuais e as coletivas devem ser, obrigatoriamente, respeitadas, assim como a garantia de participação política. Por isso é que “[...] a democracia de um estado moderno nada mais pode ser que uma democracia pluralista.”338

O pluralismo, ademais, é essencial para explicar uma característica da democracia dos modernos: a possibilidade de dissenso. A sociedade plural se vê diante do antagonismo e do conflito de interesses, que não destroem a sociedade, muito pelo contrário, promovem o debate e estimulam a participação, ${ }^{339}$ fatores que permitem a transformação política e a mudança social sem que se recorra à violência. Isso fortalece a democracia, pois um de seus maiores méritos é a resolução dos conflitos de forma pacífica:

Tudo portanto se completa: refazendo o percurso em sentido contrário, a liberdade de dissentir necessita de uma sociedade pluralista, uma sociedade pluralista permite uma maior distribuição do poder, uma maior distribuição do poder abre as portas para a democratização da sociedade civil e finalmente a democratização da sociedade civil alarga e integra a democracia política. ${ }^{340}$

sentido da liberdade positiva) adquire em Kelsen sentido diferente do de Rousseau. Para Kelsen, não há um abstrato interesse geral; o povo ativo se identifica com o partido político, capaz de organizar e afirmar os interesses individuais.

336 BOBBIO, Norberto. Verbete: Pluralismo. In: BOBBIO, Norberto; MATTEUCI, Nicola; PASQUINO, Gianfranco. Dicionário de Política. Brasília: UnB, 1986, p. 928.

337 BOBBIO, Norberto. O futuro da democracia. Trad. Marco Aurélio Nogueira. 8. ed. Rio de Janeiro: Paz e Terra, 2002, p. 72.

338 BOBBIO, Norberto. O futuro da democracia, p. 70.

339 “[...] uma sociedade em que o dissenso não seja admitido é uma sociedade morta ou destinada a morrer. BOBBIO, Norberto. O futuro da democracia, p.74.

340 BOBBIO, Norberto. O futuro da democracia, p. 76. 
Segundo Robert Dahl, a democracia ${ }^{341}$ sustenta-se a partir de um equilíbrio de forças entre os grupos sociais, que impede a eliminação uns dos outros. Esse jogo de forças pode ser sinalizado como o componente básico da ideia geral de pluralismo societal, configurando uma realidade em que a pluralidade dos grupos e partidos políticos só tem razão de ser se propicia, no regime democrático, as alternâncias de poder, ao mesmo tempo em que se constituem como fontes de poder alternativo ao governo, agindo de forma a limitá-lo e direcionando-o a escolhas e interesses. ${ }^{342}$

Esse modelo que entende as instituições políticas como mecanismos de dispersão de poder e de garantia à liberdade de expressão das demandas sociais já está presente no estudo feito por Alexis de Tocqueville sobre a democracia americana, bem como nas elaborações teóricas de James Madison, estendendo-se às análises contemporâneas de Robert Dahl e sua poliarquia.

Na perspectiva de Dahl, preservar o binômio participação X oposição é condição primeira para a efetivação de um regime político democrático pluralista, embora a abertura para a contestação e a oposição pública não seja a garantia de uma democratização plena e maximização das condições de igualdade e participação. Nos moldes da poliarquia de Dahl, a influência plural e sucessiva dos grupos existentes na sociedade prevalece mediante uma competição política estável e relativamente aberta, institucionalmente garantida, não havendo igualdade de influência para todos os grupos, nem a isenção de conflitos.

Com isso, o autor rompe com uma tradição de análise desenhada entre os democratas, que condiciona o desenvolvimento e avanço da democracia aos avanços econômicos das sociedades. Sob a perspectiva de Dahl, o parâmetro de distinção das sociedades deve ser o seu grau de pluralismo.

341 Dahl ensina que democracia é a prática de eleições com instituições e instrumentos fortes, em que processo e procedimento já estão previstos e definidos. A dúvida que surge é com relação ao resultado, já que não se pode prever quem conquistará o poder. DAHL, Robert A. On democracy. New Haven: Yale University Press, 1998.

342 DAHL, Robert. Poliarquia: participação e oposição. São Paulo: EDUSP, 1997. 
A Constituição Federal de 1988 traz em seu texto a preocupação com o pluralismo, na sociedade brasileira. Essa característica do Estado Democrático de Direito pode ser encontrada em quatro passagens da Carta Magna.

Já no preâmbulo, os constituintes garantem os valores supremos de uma “[...] sociedade fraterna, pluralista e sem preconceitos.”343

Em seguida, dispõe o art. $1^{\circ}$, inc. V, da Constituição brasileira, que dentre os fundamentos da República Federativa do Brasil estão a soberania, a cidadania, a dignidade da pessoa humana, os valores sociais do trabalho e da livre iniciativa e o pluralismo político. Com isso, fica evidenciada a exigência de que todos os demais textos legais brasileiros respeitem esses fundamentos.

Ao tratar da disciplina constitucional dos partidos políticos, a CF/88 resguarda o pluripartidarismo, alocado em conjunto com o regime democrático, os direitos fundamentais e a soberania nacional, todos eles como princípios a serem observados pelos programas e ações partidárias (CF, art. 17).

Por fim, o art. 206, III da Lei Maior refere-se ao pluralismo de ideias e concepções pedagógicas, um princípio que norteia o ensino no país.

A preocupação em definir o pluralismo político como princípio fundamental da República é de um pioneirismo ímpar e afirma a vontade que teve o legislador de incentivar e promover a participação popular e o estímulo à manifestação das mais diversas doutrinas e ideologias existentes na sociedade, assim como o incentivo à livre criação de partidos que pudessem satisfazer a todas essas manifestações de diferença. Sem dúvida, isso reflete o espírito democrático que dominava a elaboração da Constituição cidadã.

O legislador constituinte apresentou dois significados para o termo pluralismo político. Um deles é mais amplo e se refere à pluralidade de ideologias e centros de poder. A segunda acepção equipara os termos pluralismo político e pluralismo partidário.

343 BRASIL. Constituição da República Federativa do Brasil. Preâmbulo. 
No entender de Fávila Ribeiro, o pluralismo político é gênero, do qual o partidário é espécie. O pluralismo é indispensável, pois

[...] os conflitos subjacentes na sociedade precisam encontrar formações grupais mais identificadas e vinculadas aos seus específicos interesses, assumindo posições que reflitam os antagonismos que precisam encontrar válvulas institucionais descompressoras, revelando-se o sistema do pluralismo político como o componente da mais rica eficácia social, através dos diálogos, entendimentos e transações recíprocas. ${ }^{344}$

Vale lembrar que, malgrado a ênfase dada ao papel dos partidos políticos, no fortalecimento desse pluralismo, outras associações e grupos de interesse foram igualmente agraciados com essa função, como as entidades sindicais, a garantia do direito de associação, a atuação dos Conselhos Sociais Municipais, além do Conselho Tutelar. A presente análise, no entanto, mantém o foco apenas sobre os partidos políticos.

Os partidos são a porta de entrada para o exercício político, pois escolhem os candidatos e identificam soluções para os anseios do eleitor. Todavia, o que se percebe cada vez mais é uma relação verticalizada, em que os partidos formam uma aristocracia eletiva. $^{345}$

Não obstante os partidos serem tão mal vistos e receberem tantas críticas, eles acabaram se firmando no cenário político. O que eles oferecem?

O partido possui funções claras, exercidas com muita habilidade ao longo dos tempos. Ele começou como patrocinador de candidaturas, mas depois passou a promover o enquadramento do corpo eleitoral, servindo de canal de comunicação entre a comunidade e o polo decisional, função exercida com esmero durante o período

\footnotetext{
344 RIBEIRO, Fávila. Direito eleitoral. 5. ed. Rio de Janeiro: Forense, 1998, p. 88.

345 Desde sempre o partido foi visto com grande hostilidade. Rousseau, paladino da democracia direta, já demonstrava sua angústia diante das sociedades parciais, na clássica obra $O$ contrato social. O pensador genebrino estabeleceu a doutrina da vontade geral, que era a decisão política fundamental, o resultado da soma de cada uma das vontades individuais. A Assembleia na qual se reúnem todos os cidadãos é única e soberana, consagra a noção de confiança na decisão coletiva e fundamenta seu modelo democrático de participação direta, sem intermediações de qualquer corpo político. As sociedades parciais que podem ser tranquilamente equiparadas aos partidos políticos, destarte, não eram vistas com bons olhos. Cf. ROUSSEAU, Jean Jacques. Op. cit.
} 
eleitoral. Por isso, o partido é ainda considerado o mais perfeito lócus de participação política. Outros há, como as Organizações da Sociedade Civil de Interesse Público (OSCIP), ONGs e Igrejas, mas só o partido político influencia o poder, e o faz porque detém o monopólio da candidatura.

Ademais, o partido se mostrou extremamente eficaz na execução de outra tarefa: ele é o melhor amortecedor das paixões e tensões sociais. A partir do momento em que a crítica recai sobre o partido, o candidato é esquecido. O partido absorve as tensões, agressões e condenações. Isso tem feito com que, ao longo dos séculos, o partido continue sendo um ator coadjuvante indispensável para o sucesso das eleições democráticas.

A fidelidade partidária, fruto do ativismo judiciário, provocou, entretanto, uma mudança no cenário eleitoral, dando maior destaque à figura do partido, que tem assumido papel de ator principal nesse cenário. O instituto da fidelidade partidária impõe um grau de moralidade, de confiabilidade do eleitor, representa um atestado de que o candidato personifica uma ideologia, a qual será mantida ao longo do mandato. Isso produz estabilidade no colorido dos blocos do parlamento.

Por outro lado, a fidelidade atribui primazia ao partido, que acaba por se tornar mais importante do que o candidato. Ora, se o candidato se torna um soldado a serviço do partido, e não mais do grupo social que ele, em tese, garantiu defender, durante a campanha eleitoral, isso provoca uma crise na democracia e é o grande efeito colateral da fidelidade partidária. ${ }^{346}$

O STF decidiu que o voto pertence ao partido político, e não ao candidato, o que é um paradoxo, se comparado ao comportamento do eleitor ${ }^{347}$ brasileiro, que vota

346 Por isso mesmo é que alguns países, como a Espanha, não admitem a adoção desse instituto, por privilegiar o partido, e não o candidato, que é o representante legítimo do povo.

347 O comportamento eleitoral passa a ganhar relevância em número de estudos e análises a partir da segunda metade do século XX. Destacam-se os estudos feitos pelas Universidades de Michigan e Columbia, pioneiras na aplicação das técnicas de coleta de dados para a análise política e eleitoral.

O Modelo de Columbia visava a compreender o comportamento eleitoral individual, focando, inicialmente, no indivíduo, para daí estudar sua integração na sociedade e como isso afetava sua participação eleitoral. De acordo com esse modelo, quanto mais integrado o cidadão, mais exposto ele estaria aos estímulos sociais e políticos e às múltiplas fontes de informação, o que proporciona maior participação política. Portanto, o voto pode ser individual, porém, ele é diretamente influenciado pelos grupos sociais. 
no candidato - e não no partido. A motivação do eleitor é múltipla; ele pode votar em um candidato por efetivamente concordar com seu programa político, ideias e princípios; por ele ser menos corrupto do que o outro candidato da disputa; por ter recebido alguma vantagem financeira para tanto; por influência de algum meio de comunicação; dentre outros. A verdade é que brasileiro gosta de votar e se sente obrigado a votar. Mesmo que reclamando da fila de votação ou dos escândalos que invadem a mídia diariamente, há uma responsabilidade do papel de cidadão nesse momento, o que pode ser interpretado como um pequeno amadurecimento político. Não se pode nem mesmo dizer que o cidadão está obrigado a votar, afinal, as sanções são ínfimas e não intimidam. Contudo, vislumbra-se que, mesmo com apenas 25 anos de democracia e as críticas à falta de consciência política, o fato de o país inteiro mobilizar-se para ir às urnas denota amadurecimento do cidadão.

Insta salientar que os partidos políticos também têm que suportar as demandas e exigências oriundas da atuação dos grupos de pressão que atuam nos bastidores.

Os grupos de pressão são organizações bem estruturadas que defendem interesses específicos, com o objetivo de formar relações privilegiadas entre o grupo pelo qual advoga e o partido político. ${ }^{348}$ Para eles, a política é um jogo de filiações e ideologias partidárias, no qual suas reivindicações são apresentadas de maneira direta e contundente, valendo-se de informação e persuasão. ${ }^{349}$

Como se vê, a despeito do consenso de que os partidos são fundamentais para a democracia - até por deterem o monopólio da representação -, é inegável que eles

A Escola de Michigan, por sua vez, possui uma orientação que privilegia a dimensão psicológica do indivíduo. As decisões dos eleitores são tomadas, assim, em função do compromisso psicológico de cada um com a política, o dever cívico, a responsabilidade individual. Aqui, a identidade partidária ganha importância, porque está ligada a uma lealdade em relação ao partido, um fator que tende a apresentar estabilidade ao longo do tempo. PEREA, Eva Anduzia. ¿Indivíduos o sistema? Las razones de la abstención en Europa Occidental. Madrid: Centro de Investigaciones Sociológicas/Siglo XXI, 1999.

348 fortalecer o grupo de pressão, se o objetivo for alcançado. Assim, o cenário "[...] consiste à former des relations privilégiées entre un groupe et tel ou tel parti. Si la question est solvente assez simple dans les régimes bi-partisans, ele apparaît plus complexe dans les systèmes à partis multiplex. Toutes choses égales, la concurrence entre partis de tendances voisines pour une même clientèle, renforce la puissance du groupe”. MEYNAUD, Jean. Les groupes de pression. Paris: Presses Universitaires de France, 1962, p. 45.

349 MEYNAUD, Jean. Op. cit., p. 53. 
atravessam uma longa crise, a qual prejudica a intermediação entre Estado e sociedade e faz com que sua centralidade seja sistematicamente questionada.

O distanciamento entre representante e representado ${ }^{350}$ é observado em várias questões. Uma delas é a falta de proporcionalidade parlamentar, já que o número de deputados estabelecido pela Constituição Federal contradiz a igualdade de voto. Além disso, a manutenção dos chamados partidos nanicos ${ }^{351}$ não aprimorou o sistema. A pluralidade de ideias, princípios e interesses é um desideratum da democracia, porém, na verdade, a proliferação desses partidos não levou à multiplicidade de ideologias ou projetos políticos, mas à homogeneização das plataformas, partidos que se tornam legendas de aluguel, constituindo negócios privados. Isso leva a um impasse, pois a proximidade ideológica atrapalha a capacidade de renovação e de mobilização popular, em caráter permanente. E não se pode deixar de mencionar que a debilidade dos partidos políticos tem incentivado o surgimento de grupos de pressão ${ }^{352}$ que atuam nos bastidores do poder sem qualquer regulamentação ou responsabilização pelos seus atos. Nesse sentido, é importante que o lobby seja regulamentado, para que a atividade do lobista, a qual influencia a autoridade pública no atingimento de interesses privados, que são, muitas vezes, legítimos, não se confunda com o tráfico de influência, proibido pelo ordenamento brasileiro.

350 “Porque a outra característica-chave do sistema não é econômica, mas política. Trata-se da ruptura do vínculo entre cidadãos e governantes. "Não nos representam, dizem muitos. Os partidos vivem entre si e para si. A classe política tornou-se uma casta que compartilha o interesse comum de manter o poder dividido entre si mesma, através de um mercado político-midiático que se renova a cada quatro anos. Auto-absolvendo-se da corrupção e dos abusos, já que tem o poder de designar a cúpula do Judiciário.” (sic) CASTELLS, Manuel. Não é crise. É que não te quero mais. Disponível em: <http://outraspalavras.net/posts/nao-e-crise-e-que-nao-te-quero-mais/>. Acesso em: 08 ago. 11.

351 Em dezembro de 2006, o STF tornou inconstitucional a cláusula de barreira, abrindo espaço para os nanicos. Essa decisão teve como base o princípio do pluralismo, que consta no art. Da CF do Brasil. O argumento lembrado foi o de que, se há competição, há pluralismo. Todavia, essa foi, no fundo, uma decisão prejudicial para a estabilidade das instituições democráticas no país, pois levou a uma situação de ingovernabilidade da base governista. Hoje em dia, há 32 partidos políticos no Brasil, com a permanente necessidade de barganha e negociações, mas que, a rigor, garante liberdade de criação de partidos políticos.

352 Para aprofundamento do tema, indica-se: J. Berry (“The interest group society”) e V. O. Key ("Politics, parties and pressure groups"), e a tese de doutoramento de Alexandre Sanson, intitulada Dos grupos de pressão na democracia representativa: os limites jurídicos”, defendida na Universidade de São Paulo, em 2013. SANSON, Alexandre. Dos grupos de pressão na democracia representativa: os limites jurídicos. 2013. Tese (Doutorado em Direito) - Universidade de São Paulo, São Paulo, 2013. 
Ademais, é fundamental o combate à oligarquização dos partidos e à manutenção de quadros que não levam em conta um critério de competência política e administrativa, mas o mero favorecimento pessoal. O financiamento público de campanha e a adoção de lista fechada são também pontos levantados, quando se trata do tema, e que devem ser observados em uma aguardada reforma política.

É preciso mudar a percepção do papel dos partidos políticos ou muito pouco se evoluirá nessa seara. No limiar do século XXI, o mais importante parece ser não a multiplicidade de partidos políticos, mas o pluralismo no exercício e na execução da democracia, com mais instrumentos de participação popular. A Internet é um deles.

A defesa do pluralismo e da diversificação das fontes de informação em uma sociedade multimídia será fundamental para evitar uma homogeneidade cultural, desenvolver a originalidade e a diversidade, e criar condições para que as diferentes opiniões e ideologias possam interagir e criar sinergias para o desenvolvimento da humanidade. 


\title{
CAPÍTULO III - PROPAGANDA ELEITORAL COMO INSTRUMENTO DE COMUNICAÇÃO POLÍTICA
}

\author{
Tudo é igual a tudo, \\ mas por agora a unidade nos cega, \\ daí o múltiplo e suas distrações. \\ Adélia Prado ${ }^{353}$
}

Entre política e comunicação se institui uma relação muito estreita. De um lado, presentes estão as ações políticas; de outro, as ações retóricas e comunicativas dos políticos que, muitas vezes, agem “[...] compondo uma personagem que atraia a atenção e impressione a imaginação. Interpretando um papel por vezes composto.” ${ }^{354}$ Por isso, o discurso disseminado na seara política é tão significativo, pois ele se destina a dissuadir e a convencer, na busca da manutenção duradoura do poder pela personagem desenvolvida pelo homem político.

Conquistar o poder político, que é um poder de previsão, impulsão, decisão e coordenação, é um fenômeno social, que não prescinde, todavia, da influência, do encantamento e da fascinação propostos pelo jogo eleitoral executado no Estado-nação para milhões de habitantes. A figura do teatro presente na Antiguidade é aqui retomada, porém, há tempos o palco é muito maior, um palco eletrônico montado pela televisão e, nas últimas décadas, incrementado pela Internet e suas ferramentas de difusão de informação. Nessa propaganda política, aspectos afetivos e carismáticos enfeitiçam o eleitor e conduzem à versão patológica do fenômeno da personificação do poder, o qual gera o desvirtuamento desse mesmo poder. ${ }^{355}$

Nesse cenário está presente a opinião pública que, muitas vezes, parece um ente imaginário, mas que exerce uma função essencial de intermediação entre a classe política e o público. Opinião pública é um termo que possui sentido em si, mas que não consegue ser facilmente identificado. Ela mostra as exigências do público, mas também

353 PRADO, Adélia. Sala de espera. In: . Miserere. Rio de Janeiro: Record, 2013, p. 41.

354 SCHWARTZENBERG. R.G. Op.cit., p. 15.

355 Vale lembrar a forte relação existente em alguns países entre a religião e o político, quando o elemento sagrado envolve o elemento político, como ocorre no Irã fundamentalista. Além de ritos religiosos, manifestações obrigatórias de civismo também provocam desvios e são regularmente presenciadas em regimes totalitários. 
é a destinatária do espetáculo político. E, no momento das eleições, atua como um forte sujeito ativo, que serve para explicar e influenciar ações políticas, além de aprovar ou rejeitar os candidatos que se apresentam no palco eleitoral. Dessa maneira,

[...] numa democracia, governar é convencer; é conquistar a opinião pública para suas teses. A imprensa pode, entretanto, servir igualmente para "vender" pessoas, mais que ideias. E, desde os seus primórdios, muitos se interessam por ela com esse objetivo. ${ }^{356}$

Como todos esses elementos estão interligados às campanhas políticas e propagandas eleitorais, dar-se-á atenção aos seus significados, no presente capítulo. Em seguida, será realizada a análise da legislação brasileira aplicável à propaganda eleitoral, sendo observados os limites entre o direito à informação e a necessidade de regulamentação das campanhas. Por fim, serão comentadas as mudanças trazidas pela presença da Internet nas campanhas eleitorais, com propostas para o seu melhor funcionamento e aproveitamento no estímulo à participação cidadã no processo eleitoral.

\subsection{Opinião pública e Comunicação política}

\subsubsection{Opinião pública}

O estudo relativo à opinião pública é relativamente recente, já que esse fenômeno surge e ganha corpo somente a partir do século XVIII, momento em que se formam as condições necessárias para sua existência, sendo somente no ano de 1937 aparece a primeira revista direcionada para a análise do tema. ${ }^{357}$

O termo opinião está associado a um posicionamento assumido sobre uma determinada questão. Uma opinião depende de uma manifestação concreta e voluntária sobre alguma situação, e a exteriorização da ideia é fundamental para caracterizá-la. Assim, não se confunde com espírito público, crença, nem sentimento público, ${ }^{358}$ posto

356 SCHWARTZENBERG. R.G. Op.cit., p. 169.

357 Sánchez Agesta afirma que o termo opinião pública é cunhado por Riviere de la Merciere y Necker, ressaltando os estudos feitos por Saavedra e Feijoo. Cf. SÁNCHEZ AGESTA, Luis. Op. cit., p. 269270.

358 Opinião é um juízo ativo e eficaz sobre uma questão controvertida, sobre a qual se manifesta aceitação ou repulsa. As crenças podem até ser premissas maiores que embasam o juízo valorativo a 
que esses termos se relacionam a valores místicos de uma comunidade ou à cultura de um povo.

Público diz respeito, na lição de Sánchez Agesta, à porção ativa do povo, ou seja, o público é determinado por um interesse comum em obter e atingir certos feitos, ${ }^{359}$ não havendo exigência de uma quantidade determinada e constante para caracterizá-lo. Por isso, é uma estrutura fluida, não há um grupo organizado, ${ }^{360}$ mas a intenção de obter determinados interesses e a atenção e a dedicação empregadas nessa tarefa, que podem aumentar, diminuir e até mesmo desaparecer de repente, o que acarreta mudanças significativas na própria continuidade de determinada opinião pública.

Esse conjunto de indivíduos constitui, por conseguinte, um conjunto de pessoas indeterminadas, porém, é preciso definir como se dá unidade a esse desejo e objetivo comum, como se forma essa força misteriosa. Lowell ${ }^{361}$ oferece uma solução, ao definir opinião pública como o juízo de maioria não resistida, isto é, aponta que uma opinião é pública quando aceita pela maioria absoluta de cidadãos, desde que a minoria dissidente aceite a decisão de maneira voluntária, sem coação ou constrangimento. Unanimidade não é requerida para qualificá-la. ${ }^{362} \mathrm{E}$ baseia sua fundamentação em Rousseau, pois, já

embasar a opinião, contudo, com esta não se confundem. SÁNCHEZ AGESTA, Luis. Op. cit., p. 270.

359 “El público está, pues, determinado por un interés común que le hace atender a ciertos hechos. No es por eso una cantidad determinada y constante. Por eso no se localiza geográficamente y puede desbordar los límites de una comunidad política o comprender sólo parte de ella”. SÁNCHEZ AGESTA, Luis. Op. cit., p. 271.

360 Representa um “[...] aglomerado indistinto de indivíduos que compõem o público, um ator não coletivo que vive no espaço privado da domesticidade e, quando é agente sondado de opinião, atua como receptor ou espectador de um espetáculo encenado por técnicos de comunicação midiática e recitado por personagens políticos”. URBINATI, Nadia. Da democracia dos partidos ao plebiscito da audience. Lua Nova, São Paulo, n. 89, p. 86, 2013.

361 LOWELL, Abbott Lawrence. Public opinion and popular government. New York: Longmans, Green \& Co, 1913, p. 3-8.

362 Ribeiro apresenta a diferença entre democracia de unanimidade e democracia da diferença. A primeira exsurge em contextos de revolução, aqueles em que há um regime repudiado por todos, fruto de um momento histórico raro, o qual constata a fundamental importância dos valores da igualdade e da liberdade democráticas de uma forma unânime (ou, pelo menos, tem-se a forte impressão da aceitação de todos). Os exemplos dados são o da Revolução Francesa e o movimento Diretas-Já, no Brasil de 1984. A outra classificação tem por eixo o respeito ao outro como diferente e o respeito às escolhas diferenciadas. Assim, sintetiza o autor que "[...] é errado pensar que só há democracia quando o povo pulsa unido - até porque é rara essa unanimidade e os relatos das revoluções mostram quantas dissidências cada uma delas calou.” RIBEIRO, Renato Janine. A democracia. São Paulo: Publifolha, 2001, p. 57. 
que os homens são livres e obedecem aos seus intuitos, e o Estado é formado em decorrência dessa vontade geral, a partir do momento em que uma maioria expressa uma vontade, ela é, na verdade, uma vontade geral, e a minoria derrotada não é que foi atingida em sua volição pessoal, mas apenas formulou um ponto de vista equivocado sobre essa mesma vontade geral.

A atenção e o interesse da opinião pública despertam com mais intensidade quanto mais homogêneo for o fato que os une. $\mathrm{O}$ consenso ${ }^{363}$ dá unidade à opinião pública, já que evita a emergência de situações irreconciliáveis, o que gera aceitação do cidadão aos princípios básicos de uma comunidade política. ${ }^{364}$ De acordo com Sartori, essa aceitação gera um vínculo, o qual faz com que o grupo social compartilhe de “(a) valores supremos [...]; (b) regras do jogo, ou procedimentos; (c) governos específicos e políticas governamentais.”365

E qual o alcance da influência da opinião pública?

A opinião pública pode até manifestar seu papel e manifestar seus anseios e reclamações, mas é claro que há “[...] cosas que no se pueden hacer y leyes que no pueden dictarse”. ${ }^{366}$ Limites há, até para preservar o interesse comum, normas processuais, o próprio sistema representativo, isto é, aquelas questões que não podem ser alteradas, pois assentadas em um sentimento nacional maior e mais significativo. Relacionando-a ao processo eleitoral, a opinião pública é uma força importante nos embates políticos, porém, ela nem sempre estipula a agenda, e os governantes podem acatar ou não o que é proposto pela opinião pública. No fundo, ela não consegue aprimorar a democracia, nem fortalecer, por si só, os valores democráticos. Afinal, não se está diante de um povo que dita regras nem impõe seus objetivos aos governantes. Estes, por sua vez, nem sempre atenderão ao clamor público. Por isso, a dificuldade de

\footnotetext{
363 "Para que exista uma democracia basta o consenso da maioria. Mas exatamente o consenso da maioria implica que exista uma minoria que dissente.” BOBBIO, Norberto. Op. cit., p. 74.

364 “Una opinión pública como consensus se limita a los principios básicos de una comunidad política (fundamentos de una orden común, principios y reglas del juego constitucional)”. SÁNCHEZ AGESTA, Luis. Op. cit., p. 274.

365 SARTORI, Giovanni. A teoria da democracia revisitada. Vol. I - O debate contemporâneo. Trad. Dinah Abreu de Azevedo. São Paulo: Ática, 1994, p. 128.

366 “[...] coisas não podem ser feitas, e leis que não podem ser ditadas.” SÁNCHEZ AGESTA, Luis. Op. cit., p. 277.
} 
se propor argumentos definitivos sobre seus mecanismos de atuação, como explica Kuntz:

As tendências agregadas à opinião pública, muitas vezes, permanecem longos períodos inativas e latentes no seio da consciência coletiva, dificilmente detectável pelas pesquisas, até que um dia algum fator externo detone a sua espoleta e esta se revele, explosivamente, avassaladora, influindo por tempo indeterminável junto às massas, para depois refluir ao seu leito natural, aparentemente desaparecendo, dando lugar a novas tendências. ${ }^{367}$

Apesar dessa inconstância, a opinião pública consegue interferir, de alguma forma, no resultado das urnas, e sua presença no momento eleitoral merece ser analisada, bem como sua capacidade de pressão sobre os grupos dirigentes.

Noelle-Neumann ${ }^{368}$ elabora estudo sobre mídia e opinião pública, nos anos 1950. Para a autora alemã, as pessoas tendem a se expressar menos, deixando de manifestar sua opinião, a partir do momento em que elas se veem como minoria. Para evitar um isolamento por parte da comunidade da qual participam, ou críticas à sua forma de pensar, as vozes minoritárias discordantes se calam. É a denominada “espiral do silêncio”, a qual atinge o cidadão desinformado ou com medo do governo e da opinião da maioria. Para lançar luz sobre a obra: ${ }^{369}$

[...] ao perceberem ou imaginarem que a maioria das pessoas pensa diferentemente delas, essas pessoas acabam, num primeiro momento, por se calarem, e, posteriormente, a adaptarem, ainda que muitas vezes apenas verbalmente, suas opiniões às do que elas imaginam ser a maioria. Em consequência, aquela opinião que, talvez de início, não fosse efetivamente a maioria, acaba por tornar-se opinião majoritária, na medida em que se expressa num crescente movimento de verbalização, angariando prestígio e alcançando a adesão dos indivíduos.

A despeito das críticas sofridas nos anos 1990, no sentido de que não se pode demonstrar até que ponto o medo do isolamento social interfere na opinião pública, ou precisar se isso caberia em qualquer comunidade, a contribuição de seus estudos é

367 KUNTZ, Ronald A. Marketing político: manual de campanha eleitoral. 11. ed. São Paulo: Global, 2006, p. 234.

368 NOELLE-NEUMANN, Elisabeth. La espiral del silencio - Opinión pública: nuestra piel social. Barcelona: Paidós, 1995.

369 HOHLFELDT, Antonio, MARTINO, Luiz; FRANÇA, Vera Veiga. Teorias da comunicação: conceitos, escolas e tendências. Petrópolis, RJ: Vozes, 2001, p. 137. 
importante, se observada em conjunto com as pesquisas de opinião pública. Muitos analistas investigam se as pessoas são sinceras nessas sondagens, se o resultado influencia o voto, ou mesmo se elas deveriam ser apresentadas antes das eleições. Questões controversas e que, até mesmo por isso, continuam a ser debatidas.

Nos Estados Unidos, por exemplo, os efeitos bandwagon e underdog são mencionados desde o começo do século XX pelos estudiosos, no entanto, como ressalta Hollander, muito da literatura existente é especulativa. ${ }^{370}$

Pelo efeito bandwagon, as pessoas tendem a votar em candidatos ou partidos com mais chances de ganhar a eleição - ou assim afirmado pela mídia. É um processo que tem início com o lançamento da candidatura e pode ganhar força com a campanha eleitoral. Quanto mais pessoas ela conseguir mobilizar, mais atenção atrai e mais votos conquista. As pesquisas de opinião, ainda de acordo com essa hipótese, teriam grande influência sobre os votos, provocando mudanças nos votos dos cidadãos, os quais acabariam votando de acordo com a maioria.

Por sua vez, o efeito underdog (a zebra das eleições) atesta o contrário, que as pessoas tenderiam a votar contra os favoritos, a favor da minoria, por uma simples questão de piedade.

Essa é outra polêmica inconclusiva. Alguns autores a defendem, outros reduzem o tema a fatores psicológicos, ou seja, algumas pessoas são mais influenciáveis que outras, e há ainda autores para quem as pesquisas eleitorais influenciam mais os financiadores de campanhas do que os eleitores. ${ }^{371}$

Neste ponto, as reflexões de Sartori são retomadas, pois ele foi o cientista político italiano que tratou com mais profundidade dos meios de comunicação, em obra mencionada em capítulo anterior, Teoria da Democracia Revisitada. Ocorre que, no contexto histórico focalizado por ele, em que predominava o credo liberal, Sartori

370 HOLLANDER, Barry. Explaining the "bandwagon"” and "underdog” effects: a study of personal relevance and uncertainty orientation as factors in public opinion poll influence. 1991. Tese (Doutoramento em Filosofia) - Universidade da Flórida, 1991. Disponível em: <https://archive.org/stream/explainingbandwa00holl\#page/5/mode/2up>. Acesso em: 28 nov. 2013.

371 Herbert A. Simon possui obras que suportam as diferenciações, enquanto Barry Hollander é um dos autores que credita o fato à personalidade de cada um. 
abordou as condições de uma opinião pública autônoma, assentindo com o fato de que ela seria regulada pelos mecanismos de mercado, os quais exerceriam um controle recíproco sobre as instituições, com um canal de informação a vigiar o outro, resolvendo o conflito de modo satisfatório. ${ }^{372}$

É apenas com seu Homo videns que Sartori traça uma crítica mais ácida aos meios de comunicação, mostrando a interferência da televisão nas comunidades políticas como um dos grandes obstáculos para o desenvolvimento das democracias ocidentais. A classe política não age apenas com base em decisões próprias ou fundamentadas no programa partidário. Ela busca respaldo em vários mecanismos de manipulação para agradar a opinião pública e passa a controlá-la, reduzindo sua capacidade de discernimento. A mídia também exerce sua influência nociva, manipulando informações e orientando resultados, exercendo uma forma de persuasão nos confrontos entre os governantes e transformando a opinião pública em um importante sujeito do espetáculo político. Esse conjunto, infelizmente, desarticula a participação política. ${ }^{373}$

A opinião pública pode constituir um freio do poder político, quando ela se apresenta sob uma organização consciente e bem estruturada, ${ }^{374}$ com objetivos claros e possíveis de serem viabilizados. Nesse caso, ela pode pressionar, pelo voto, ${ }^{375}$ as instituições políticas e jurídicas, e até provocar alterações inesperadas no jogo pelo poder.

372 SARTORI, Giovanni. Op. cit., p. 137-145.

373 SARTORI, Giovanni. Ibidem.

374 Sánchez Agesta assevera que a presença do povo deve ser incitada: "El pueblo es instrumento de varias voces, que jamás se pondrán por sí mismas en el debido tono hasta que alguna mano las temple.” A opinião pública precisa ser formada e organizada, e os candidatos têm que estar abertos ao imponderável, pois essa opinião pode aprovar ou criticar, aplaudir ou vaiar. Para conduzir essa atuação, geralmente há um organizador capaz de atingir o lado emotivo ou irracional dessas manifestações, conduzindo a opinião para outra orientação. SÁNCHEZ AGESTA, Luis. Op. cit., p. 268.

375 "Even though the upper-middle class dominates the political process in any event, the force of public opinion still makes itself felt through the ballot box, and cannot be ignored by elected politicians no matter how enlightened and progressive they might be. Hence the desire to further diminish the influence of 'public opinion'." GOLDSWORTHY, Jeffrey. Parliamentary Sovereignity Contemporary debates. Cambrigde: Cambridge University Press, 2010, p. 9-10. 
Pode-se inferir que a relação existente entre a opinião pública e as instituições políticas é uma relação dialética, e não linear. Uma afeta a outra, principalmente no que tange à influência da mídia, considerada, por Thimothy Cook, como uma instituição política posicionada no mesmo nível que os demais três poderes constitucionais. ${ }^{376} \mathrm{O}$ direito à informação é fundamental em uma sociedade democrática, e a ele corresponde o dever de comunicar, o qual recai sobre os representantes, que devem explicar suas escolhas e decisões. A mídia é capaz de intermediar essa comunicação; entretanto, sua abordagem sobre um tema e sua ênfase ou desinteresse sobre um determinado aspecto da realidade podem ser tendenciosos, provocando uma influência deturpada e manipulada pelos meios de comunicação sobre a opinião pública, que termina por acatar a pauta imposta pela mídia. ${ }^{377}$

O cerne da reflexão de Cook está na observação de que mídia tem assumido claramente uma ingerência sobre os rumos da governança democrática, todavia, sem poder fazê-lo, pois ela não recebeu o voto popular, ela não possui um mandato de representação e, assim, ela acaba por ter poder político, sem que haja a fundamental contraprestação da responsabilidade política pelos seus atos, o que é prejudicial para a democracia.

Cumpre mencionar que mais recentemente, na história brasileira, tem-se notado a atenção vigorosa com a qual a mídia cobre o Poder Judiciário. Esse é um fato novo que deve despertar cuidados. Afinal, juízes devem agir com imparcialidade, mas, quando debaixo dos holofotes da mídia, podem deixar-se influenciar, mesmo que de forma indireta ou não declarada. Com isso, há uma aproximação entre a agenda do Supremo, a agenda da mídia e a agenda da opinião pública. Garapon é enfático, ao pontuar que

[a] ameaça que a mídia faz pairar sobre o embasamento simbólico da justiça pode revelar-se talvez mais perigosa que os atentados contra algumas liberdades públicas. O símbolo, na verdade, distancia. Ora, a mídia abole as três distâncias essenciais em que se baseia a justiça: a delimitação de um espaço protegido, o tempo diferenciado do processo e a qualidade oficial dos personagens de seu drama social.

\footnotetext{
376 COOK, Thimothy. Governing with the News: the News media as a policial institution. Chicago: The University Press, 1998.

377 Cook enfatiza que os detentores do poder definem o que é importante, mas a mídia define o que é interessante. COOK, Thimothy. Op. cit.
} 
Ela desloca o espaço judiciário, paralisa o tempo e destitui a autoridade. $^{378}$

Obviamente, a transparência é vital para a democracia e a mídia não deve simplesmente ser vista como a causa de todos os males; ela também é essencial para o processo democrático, a partir do momento em que investiga os acontecimentos, denuncia ilegalidades e apresenta os fatos de forma isenta, além de unir os cidadãos em ações comuns, provendo-os de informações locais e nacionais de toda espécie, como se ainda estivesse presente o espírito das associações descritas por Tocqueville, que, à sua época, já era grande defensor da liberdade de imprensa. ${ }^{379}$

Por outro lado, é difícil negar que ela se submete igualmente à lógica do mercado e veicula clichês que atraem a atenção do público. Esse desvirtuamento da realidade precisa ser coibido, porque, uma vez veiculado o fato, mesmo com o direito de resposta, os danos podem ser irreversíveis. O mesmo ocorre em um processo judicial, que segue outro rito e tempo, no qual as alegações e contestações não podem ser contaminadas, e em cujo ambiente se exige total imparcialidade do juiz, o qual não pode ceder às pressões da mídia nem da opinião pública, devendo apenas cumprir seu dever de respeito às leis e à Constituição de seu país. ${ }^{380}$

Downs, por sua vez, demonstra a natureza vaga e transitória da opinião pública em questões ligadas a políticas públicas pontuais. Tomando como exemplo de pesquisa o caso específico do meio-ambiente, ele conclui que a atenção pública era capturada durante um tempo e, à medida que o debate se tornava mais complexo, ou quanto mais difícil se tornava chegar a uma solução para o problema, a importância dada ao tema desaparecia. Em suas palavras:

378 GARAPON, Antoine. O juiz e a democracia: o guardião das promessas. Trad. Maria Luiza de Carvalho. 2. ed. Rio de Janeiro: Revan, 2001, p. 76.

379 “A soberania do povo e a liberdade de imprensa são, pois, duas coisas inteiramente correlativas. A censura e o voto universal são, ao contrário, duas coisas que se contradizem e não podem se encontrar por muito tempo nas instituições políticas de um mesmo povo.” TOCQUEVILLE, Alexis de. Op. cit., p. 209.

380 É essa a razão pela qual Garapon pede cautela na adoção da filmagem em tempo real das audiências, pois elas podem se transformar em um "espetáculo estranho à justiça”. GARAPON, Antoine. Op. cit., p. 89. Da mesma forma, a opinião pública pode ser contaminada por esse show midiático, que não aceita questionamentos exteriores: “A mídia torna tudo transparente, salvo o ponto de onde se origina essa transparência. Talvez seja por isso que os homens da mídia relutam tanto em participar de debates públicos sobre a própria mídia, exceto se acontecem dentro do seu próprio espaço.” GARAPON, Antoine. Op. cit., p. 81. 
[...] a atenção do público raramente permanece firmemente focada sobre qualquer questão doméstica por muito tempo - mesmo quando envolve um problema de importância crucial para a sociedade. Em vez disso, um "ciclo de atenção a questões" sistemático parece influenciar fortemente as atitudes e comportamento do público em relação à maioria dos problemas domésticos centrais. Cada um desses problemas repentinamente surge como predominante, assim permanece por algum tempo e então - ainda que não resolvido gradualmente desaparece do centro da atenção pública. ${ }^{381}$

Marrone traça um paralelo desalentador entre o discurso político e a opinião pública. Segundo o autor, o cidadão deixa de ser uma unidade integral, quando analisado sob a ótica do discurso político, porque, se fora desse cenário ele é um cidadão que pode assumir várias facetas, para o mundo da política ele é apenas um eleitor, visto como uma entidade, um número. E, enquanto eleitor, ele só faz sentido quando visto e contabilizado em conjunto com outros eleitores, o que o faz ser um número ainda mais perdido no coletivo. A opinião pública nasce, destarte, da negação do público, da negação do cidadão, posto que

[...] não é a expressão política do cidadão como unidade integral, a entidade semi-institucional que dá voz à chamada sociedade civil, mas o resultado de um complexo e sub-reptício trabalho de cancelamento do mesmo cidadão, que não só é reduzido a entidade partitiva, mas é até privado do único poder que lhe restou: o voto. Quem diz ser em favor ( ou falar em nome) da Opinião pública, elevando-se a paladino do povo, perpetua esta dupla remoção, agindo como silencioso monopolizador de/poder/puro (sic). ${ }^{382}$

Defendemos aqui uma postura menos pessimista do que a apresentada por Marrone. Apesar de a opinião pública ser tratada quase como um ente mítico em tantos discursos políticos que o resgatam e mencionam, para justificar ações e se esquivar de responsabilidades, ou associado à manipulação que sofre da mídia e dos donos do poder, ela ainda é eficaz do ponto de vista comunicativo e pode influenciar de forma positiva ações políticas, assumindo um papel de mediador social. Com base na obra de Katz e Lazarsfeld, advogamos que há uma nova perspectiva diante dos efeitos dos meios de comunicação, os quais devem ser compreendidos não separadamente, mas a partir das relações recíprocas estabelecidas entre mídia e povo. É bom lembrar que a

381 DOWNS, Anthony. Up and down with ecology - the 'Issue-Attention Cycle'. The Public Interest, Boca Raton/Flórida, n. 28, p. 38-50, 1972.

382 MARRONE, Gianfranco. Da opinião pública ao corpo político. São Paulo: Galáxia: revista transdisciplinar de comunicação, semiótica, cultura, p. 57-98, 2001. 
opinião pública pode ser auferida por meio do voto, da iniciativa popular, plebiscito, bem como pelos mecanismos de alta tecnologia que abrem cada vez mais espaços para debates e troca de ideias e podem, um dia, vir a retratar de forma fiel a opinião pública.

Ademais, Katz e Lazarsfeld salientam que os efeitos dos conteúdos divulgados nos meios de comunicação dependem das forças sociais atuantes em determinados períodos de uma comunidade. No mesmo sentido, a atitude política depende do desenvolvimento das relações sociais. A credibilidade que os líderes de opinião conquistam também reflete uma maior eficácia de persuasão dos membros de uma dada comunidade, o que significa uma vantagem frente aos supostos efeitos buscados pelos meios de comunicação. ${ }^{383}$ Assim é que, por exemplo, a opinião pública pode afetar uma tomada de decisão política a partir do momento em que o governo tem que posicionar sua campanha eleitoral futura de acordo com o grito do povo nas ruas, o qual, com isso, conseguiu o grande feito da redemocratização do espaço público. Foram a conjuntura social e a insatisfação generalizada - identificadas e estimuladas pelas mídias sociais que serviram de estopim para as manifestações e pressionaram o governo por algumas ações que, mesmo pontuais, foram alcançadas.

As teorias elitistas sempre promoveram a ideia do povo passivo e apático, sem interesse pelas questões políticas, que devem ser decididas por pessoas competentes para tanto. Todavia, a apatia não é inata; ela tem que ser produzida. Em função do momento histórico e das condições sociais em que se encontram, os indivíduos redefinem seus interesses e objetivos e, de tempos em tempos, presencia-se a massa tomando de assalto o palco político e mudando o papel dos personagens centrais:

O próprio da democracia é proceder por oscilações, praticando, assim, espontaneamente, a compensação dos erros. A lassidão do povo, as flutuações da opinião pública são muitas vezes reveladoras, suas aspirações são indicações, o direito de voto não é outra coisa senão uma pesquisa sociológica. Mas com a condição, no entanto, de que a opinião esteja suficientemente esclarecida, que ela possa julgar com uma certa serenidade, isto é, não se escolhendo para consultá-la os períodos de pânico ou de impulsos catastróficos. Enfim, que possa ela escutar a exposição livre das teses em jogo e capaz de compreendê-las ainda que em termos restritos. [...]

383 LAZARSFELD, Paul; KATZ, E. Personal influence: the part played by people in the flow of mass communication. New York: Free Press, 1955. 
A maior parte dos historiadores acredita que se os povos italiano e alemão tivessem sido consultados em eleições livres pouco antes da instauração do fascismo e da tomada de poder por Hitler certamente os teriam jogado na minoria. ${ }^{384}$

A opinião pública está vinculada ao pressuposto da liberdade. ${ }^{385}$ Somente com a liberdade de manifestação, de expressão e de reunião existentes em um Estado democrático de direito estão presentes as condições jurídicas que efetivam a opinião pública e lhe impõem limites, já que a opinião de um não pode ofender a liberdade dos demais. O conceito de liberdade assegura a opinião pública como instrumento a provocar a participação cidadã dentro do Estado de direito e deve receber o olhar atento dos partidos políticos, cuja função interpretativa dessas opiniões pode ajudar a melhorar a intermediação entre sociedade e Estado. Nesse diapasão, o raciocínio de Habermas:

Essa opinião pública [...] precisa estar inserida no contexto de uma cultura política liberal; e também precisa ser sustentada pela livre condição associativa de uma sociedade civil em direção à qual possam afluir experiências socialmente relevantes, advindas de campos vitais privados que constituem intactos, a fim de que se possa elaborá-las nessa mesma sociedade civil e transformá-las em temas passíveis de recepção pela opinião pública. Os partidos políticos - não estatizados - precisam permanecer tão enraizados nesse complexo, a ponto de se mostrarem capazes de intermediar, por um lado os campos de comunicação informal pública e, por outro, os processos institucionalizados de deliberação e decisão.”386

Em relação ao cenário eleitoral brasileiro, o que se pode dizer sobre a influência da Internet sobre a opinião pública nas últimas eleições a contar com essa ferramenta é que, apesar de sua popularização, dos inúmeros blogs de candidatos e da formação de grupos dentro das campanhas, dedicados a cuidar dos debates e notícias os

384 MOSCA, Gaetano; BOUTHOUL, Gaston. História das doutrinas políticas desde a Antiguidade. Trad. Marco Aurélio de Moura Matos. 6. ed. Rio de Janeiro: Zahar, 1983, p. 360.

385 Mencionamos Kant pelas valiosas contribuições ao ideal da liberdade e sua ligação com a expressão do pensamento - de certa forma, uma opinião pública: “À liberdade de pensar contrapõe-se a coacção civil. Há decerto quem diga: a liberdade de falar ou de escrever pode ser-nos tirada por um poder superior, mas não a liberdade de pensar. Mas quanto e com que correção pensaríamos nós se, por assim dizer, não pensássemos em comunhão com os outros, aos quais comunicamos os nosso pensamentos e eles comunicam os seus! Pode, pois, muito bem dizer-se que o poder exterior, que arrebata aos homens a liberdade de comunicar publicamente os pensamentos, lhes rouba também a liberdade de pensar.” KANT, Immanuel. Que significa orientar-se no pensamento? Trad. Artur Morão. em: <http://www.lusosofia.net/textos/kant_que_significa_orientar_se_no_pensamento_1786_.pdf>. Acesso em: 22 out. 2013, p. 18.

386 HABERMAS, Jürgen. A inclusão do outro - estudos de teoria política. Trad. George Sperber, Paulo Astor Soethe e Milton Camargo Mota. 3. ed. São Paulo: Loyola, 2007, p. 188. 
quais circularam no Facebook e Twitter, seu impacto no universo eleitoral brasileiro foi pequeno - diferentemente do que aconteceu nas eleições presidenciais norte-americanas de 2008. Todavia, acredita-se que a Internet se transformará em um diferencial cada vez mais importante nas eleições futuras, e seu uso como meio de produção de notícias e como termômetro a medir as intenções de voto não pode, de maneira alguma, ser subestimado. O tema será retomado com maiores detalhes e estatísticas no Capítulo 4.

\subsubsection{Comunicação política}

A compreensão da relação entre comunicação e política deve compreender a crescente influência da opinião pública e da mídia, o que justifica a análise acima apresentada. A mídia conquistou centralidade na vida política contemporânea especialmente com o alcance e a rapidez das informações transmitidas pela Internet -, de sorte que a opinião pública tem acompanhado a expressão política por meio das opções fornecidas em ambiente virtual. A proliferação dessas informações e mensagens acentua a transparência das práticas políticas e desmistifica os representantes eleitos, que veem sua credibilidade posta à prova. Esse ambiente é salutar para o progresso democrático.

Esse tipo de comunicação, entretanto, nem sempre foi bem aceito. Explica Duarte $^{387}$ que, durante os anos 1930, na era Vargas, a comunicação política era vista como um instrumento de controle da opinião pública e do direito de expressão. Nada que se compare com a importância estratégica que possui nos dias de hoje, quando os comunicadores se valem de todos os conhecimentos técnicos que possuem para tornar as campanhas atraentes, com um slogan memorável e com a participação de ídolos populares. ${ }^{388}$ A mídia é capaz de focar em determinados elementos para elaborar realidades e acontecimentos diversos, com o intuito de influenciar o eleitor (ou será o

387 DUARTE, Jorge. Assessoria de imprensa e relacionamento com a mídia: teoria e técnica. São Paulo: Atlas, 2002, p. 9-10. Apesar disso, Getúlio Vargas não deixou de adotar um jingle de campanha para as eleições presidenciais de 1950, uma verdadeira marchinha de carnaval chamada "Retrato do velho”, considerada uma pérola do marketing político. A campanha pode ser acessada pelo You Tube.

É de se notar que aqueles que mais utilizam os profissionais da área, como publicitários, jornalistas e webdesigners, são as prefeituras, governos do Estado e federal, veiculando várias campanhas institucionais ao longo de seus mandatos sobre os feitos realizados por sua administração. $\mathrm{O}$ investimento em propaganda institucional é consideravelmente alto. 
consumidor de um produto ${ }^{389}$ ) a favor do candidato que defende. Essa postura afeta a legitimidade da representação política, pois a escolha do candidato é influenciada por um poder simbólico. ${ }^{390}$

Miguel 391 assevera que os meios de comunicação modificaram consideravelmente a percepção da realidade política. Primeiramente, isso se deve ao fato de as pessoas passarem a ter acesso a uma quantidade muito maior de informações. Além disso, o discurso político se vê obrigado a se adaptar à lógica discursiva imposta pela mídia. No que diz respeito à informação sobre política, o autor ainda entende que a mídia transmite sua perspectiva da política não somente nos espaços noticiosos, mas também na programação de entretenimento, como novelas e programas de auditório.

Os pressupostos teóricos que apresentam uma crítica aos meios de comunicação de massa e à comunicação política remetem aos estudos feitos pela Escola de Frankfurt. ${ }^{392}$ Teóricos como Adorno, Horkheimer e Marcuse, seguidos por Habermas e J. Thompson, estabeleceram algumas afirmativas centrais, como a impossibilidade de neutralidade. Toda ciência é uma ação e, portanto, não pode ser neutra. Assim como todo conhecimento é reflexivo, isto é, à medida que conhecemos algo, também sofremos algum tipo de informação.

A relevância da teoria crítica formulada por esses autores está na circunstância de eles terem observado que os meios de comunicação modificam a maneira como o

389 Alguns autores relacionam o marketing eleitoral com a campanha de um produto. Os partidos políticos competem entre si pelos eleitores e, para "vender" seus candidatos, as formas de persuasão disponíveis são basicamente as mesmas: contato pessoal e meios de comunicação de massa, especialmente a mídia eletrônica. MAUSER, Gary. Political marketing: an approach to campaign strategy. New York: Praeger, 1983.

390 Exemplo claro foi a eleição de Fernando Collor, em 1989, ano em que o Brasil vivia um momento político único, podendo eleger pelo voto direito o Presidente da República. A mídia mostrava a imagem de um jovem governador do Nordeste, bem apessoado e "caçador de marajás". A notória manipulação do debate político entre Lula e Collor pela Rede Globo deu a vitória para este último. A realidade de seu mandato foi desastrosa para o país, todavia, os marqueteiros cumpriram muito bem seu papel. Essa eleição significou um divisor de águas para o marketing político brasileiro e alavancou o estudo do tema.

391 MIGUEL, Luís Felipe. Mito e discurso político: uma análise a partir da campanha eleitoral brasileira de 1994. Campinas, SP: Editora da UNICAMP: Imprensa Oficial, 2000.

392 Os primeiros estudos sobre comunicação política surgem nos Estados Unidos, entre as décadas de 1920 e 1930, resultado dos desdobramentos trazidos pelo desenvolvimento capitalista, urbanização, imprensa, cinema e rádio. O impulso em período posterior é dado pelo surgimento da televisão. Cf. RUBIM, Antonio A. C. Comunicação e política. São Paulo: Hacker, 2000, p. 14. O recorte aqui feito remete à escola alemã, pela singularidade do estudo e influência provocada até hoje. 
político trata seus eleitores, a partir do momento em que ela passa a ser mediada por um aparelho eletrônico. Há muito a televisão não veicula campanhas partidárias, mas campanhas pessoais dos candidatos, que se expõem, por vezes, em alguns segundos, mas conseguem, com isso, criar uma identificação e envolvimento com o eleitor. ${ }^{393}$

O problema decorre daquela falta de neutralidade. Se as redes de comunicação e os comunicadores não são neutros, as informações são manipuladas e distorcidas, o que, por evidente, constitui práticas antidemocráticas e ideológicas questionáveis.

Habermas discorre sobre seu ponto de vista à época, na obra Mudança estrutural da esfera pública, sendo a esfera pública a esfera social formada pela comunicação. A partir do instante de sua formação, a esfera pública cria uma nova relação entre Estado (público) e sociedade civil (privado). Os indivíduos, reunidos em público, constroem um diálogo aberto, sem interferência do poder político e econômico, baseado na racionalidade do melhor argumento. O público possui poder de reflexão e condições de levar adiante uma discussão política. Como na pólis grega, há um princípio normativo que permite o acesso de todos a essa esfera (um espaço que não coincide com o Estado nem a sociedade civil), uma verdadeira comunidade de cidadãos reunidos publicamente e deliberando sobre as questões de Estado, que seriam resultado das opiniões privadas de cada um dos participantes, opiniões verdadeiras e depuradas.

Essa esfera pública, contudo, não tarda a se enfraquecer. O acesso universal é questionado, a formação intelectual exigida para a participação não se desenvolve a contento e surgem novos grupos sociais que impõem conflitos os quais não conseguem mais ser resolvidos nesse ambiente. E a imprensa, que contribuía para o debate público, cede ao avanço da sociedade de consumo. O resultado é a dominação (ou colonização, como prefere o autor) da esfera pública pelas leis do mercado e, com isso, “[...] o

393 Vide as clássicas campanhas políticas de Enéas, que não duravam nem 20 segundos e nas quais nada era proposto: o candidato tinha tempo apenas para dizer seu nome e número. Porém, isso foi o suficiente para ele receber 1.573.642 votos, em 2002. Ou, então, de Tiririca, que se autointitulava “o abestado" e cujo slogan era: "Vote em Tiririca, pior do que está não fica.” Também foi eleito, ficando próximo da votação recebida por Enéas. Para a campanha de 2014, o slogan é: "Sem Tiririca, Brasília mica”. Todos os vídeos estão à disposição no You Tube. Disponível em: <http:/g1.globo.com/especiais/eleicoes-2010/noticia/2010/10/mais-votado-do-pais-tiririca-naoconsegue-bater-recorde-de-eneas.html>. Acesso em: 10 out. de 2012. 
raciocínio tende a se converter em consumo e o contexto que comunicação pública se dissolve nos atos estereotipados da recepção isolada.”394

A esfera pública e os meios de comunicação estariam intrinsicamente ligados, sendo estes últimos os responsáveis pela despolitização da esfera pública, ao estimular o consumo. O grande número de consumidores influenciados pela mídia demonstra o processo de transição de um público que, se antes era capaz de refletir e pensar, agora é apenas consumidor de cultura. A esfera pública abandona sua capacidade crítica para assumir funções de propaganda, e, em decorrência, se distancia por completo da esfera pública literária. ${ }^{395}$ Os jornais, outrora instrumentos que divulgavam a argumentação e o debate, convertem-se em fins privados de manipulação: "Enquanto antigamente a imprensa só podia intermediar e reforçar o raciocínio de pessoas privadas reunidas em público, este passa agora, pelo contrário, a ser cunhado primeiro pelos meios de comunicação de massa.”396

Críticos da obra de Habermas apontam que a teorização sobre essa influência provocada pelos meios de comunicação foi abandonada ${ }^{397}$ nas obras posteriores do estudioso alemão. Garnham ${ }^{398}$ ressalta que esse estudo inicial de Habermas, indicando a centralidade dos meios de comunicação no debate político, foi fundamental para despertar o interesse de outros analistas sobre o tema. O problema de Habermas foi não ter construído um sistema que abordasse a responsabilidade democrática dos meios de comunicação. $^{399}$

394 HABERMAS, Jürgen. Mudança estrutural da esfera pública. São Paulo: Tempo Brasileiro, 1984, p. 190.

395 A esfera pública literária era identificada pelos centros, como os cafés, salões, associações literárias, que simbolizavam o espaço de crítica e intermediação entre Estado e sociedade.

396 HABERMAS, Jürgen. Op. cit., p. 284.

397 Na sua revisão teórica, Habermas considerou que os meios de comunicação não manipulam objetivamente as pessoas, pois estas trocam informações e podem refletir sobre o que recebem de informação.

398 GARNHAM, Nicholas. The media and public sphere. In: CALHOUN, Craig (Ed.). Habermas and the public sphere. Cambridge/ Massachusets: MIT Press, 1992.

399 Raciocínio similar é desenvolvido por Cook. Para o autor, se a mídia representa uma instituição de intermediação entre Estado e sociedade, ela detém poder sobre os rumos da governança democrática. Contudo, não possui mandato de representação para tanto. Como a sociedade pode exigir transparência e responsabilidade da mídia, nesse caso? O autor desenvolve em sua obra limites e oportunidades de uso da mídia no debate político. COOK, Timothy. Governing with the News: the news media as a political institution. Chicago: The University of Chicago Press, 1998. 
Debates atuais reconhecem que os cidadãos estão consumindo cada vez menos política e mais entretenimento. A televisão a cabo possibilita o acesso a inúmeros canais e a uma grande variedade de programas. O sistema pay-per-view permite ao consumidor comprar apenas os tipos de programa a que deseja assistir. Há um declínio da audiência dos canais de notícias, que tentam se reformular com programas e debates oferecidos na Internet. O uso cada vez mais expressivo de computadores, tablets e celulares, no mesmo sentido, propicia uma variedade de produtos culturais, acesso a filmes, música e jogos, detendo a atenção dos usuários nas redes sociais. ${ }^{400}$ A interação com esses mecanismos e o fato de os próprios usuários serem os fornecedores e criadores do conteúdo de suas mídias evidencia um declínio do envolvimento com questões públicas $^{401}$ e o aumento da produção de informações ligadas a círculos cada vez mais individualizados.

Em outro sentido, ${ }^{402}$ analistas destacam que a verificação do interesse pelos sites de entretenimento, em detrimento dos de política, não necessariamente revela o enfraquecimento dos efeitos políticos dos meios de comunicação, por entenderem que aqueles englobam igualmente questões políticas. A forma de apresentação do tema é outra. Muitos cidadãos utilizam a rede social Facebook e Twitter para focalizar notícias políticas, feitos dos candidatos ou críticas à sua atuação. Isso seria uma prova de que os campos midiáticos e políticos estão cada vez mais intricados, e que a tecnologia tem sido usada para expressões políticas.

Nessa perspectiva, Fleiner-Gerster coloca a questão:

Não é tarefa muito fácil estabelecer a posição do leitor, do ouvinte e do telespectador. Devem ser entendidos como um consumidor que acolhe informações mas não precisa digeri-las, ou como um cidadão esclarecido que, por exemplo, pode e quer exercer uma influência

400 Relatório produzido pela ComScore afirma que, no começo do ano de 2013, o tempo médio de uso nacional do Facebook foi de 12,5 horas, ou seja, metade de um dia. E esse número representou um aumento de 98\% em relação a fevereiro de 2011. Disponível em: <http://www3.globo.com/Cienciae-tecnologia/noticia/2013/04/tempo-gasto-por-brasileiros-com-o-facebook-dobra-em-um-ano.html>. Acesso em: 15 abr. 2013.

401 Nesse sentido, ver PRIOR, M. Post-broadcast democracy: how media choice increases inequality in political involvement and polarizes elections. Cambridge: Cambridge University Press, 2007.

402 Dentre aqueles que veem um papel positivo entre essa ligação mídia e política, indicamos: HOLBERT, R.; GLEASON, L. A new era of minimal effects? A response to Bennett and Iyengar. Journal of Communication, Milwaukee, 60, 15-34, 2010. 
sobre os programas e a política de pessoal por meio das eleições dos delegados de televisão? ?03 $^{403}$

Mesmo não havendo consenso em relação aos impactos da mídia e política, em especial nos processos eleitorais, parece que isso tem levado ao enfraquecimento das organizações partidárias e ao fortalecimento da personalização da política, criando condições favoráveis para a ampliação do voto definido em função de atributos simbólicos dos candidatos (bom desempenho no vídeo, simpatia e outros elementos ligados ao primado da imagem), ao invés de prestigiar propostas programáticas consistentes. A queda de prestígio dos jornais e televisão, ao mesmo tempo, sugere que as experiências comunicativas e a abordagem dos temas afastam os cidadãos dessas mídias tradicionais. ${ }^{404}$ É fato que as profundas mutações provocadas pela revolução tecnológica diminuíram a publicação dos jornais e a audiência televisiva, já que as pessoas se valem do acesso aos computadores para ler as notícias ou ver seus programas favoritos. Entretanto, esse acesso abriu um maior número de informações aos cidadãos, que conseguem visualizar a capacidade de manipulação e uma notícia, a falta de neutralidade de algumas coberturas jornalísticas e televisas ou a futilidade de alguns temas. A estratégia de fazer programas apelativos e sensacionalistas não tem cativado os cidadãos como outrora. Talvez isso represente o despertar do uso das tecnologias para um progressivo aumento da participação política.

Seja criticando, seja enaltecendo a relação entre campos midiáticos e políticos, o que importa ressaltar é que a proximidade entre ambos é inquestionável. A mídia pode incluir ou excluir temas, desvirtuar histórias, enfatizar conquistas e construir discursos; cabe ao campo político apresentar uma postura ativa em relação a essas colocações, e ao eleitor consciente fazer suas escolhas. Mais uma vez, destaca-se a ponderação de Miguel:

403 FLEINER-GERSTER, Thomas. Teoria geral do Estado. Trad. Marlene Holzhausen. São Paulo: Martins Fontes, 2006, p. 558.

404 Dados do Observatório da Imprensa demonstram a queda da audiência televisiva; revelam igualmente que cerca de 63 milhões de brasileiros vivem em casas com pelo menos um computador com acesso à rede; houve crescimento de $29 \%$ nos acessos a sites de notícias de anos passados para 2013 e que "[...] o público [dá] preferência a informações de fonte terciária, que já chegam através da própria rede de usuários, embaladas em um grande conjunto de apreciações.” Disponível em: $<$ http://www.observatoriodaimprensa.com.br/radios/view/gt_gt_o_futuro_da_mida_lt_br_gt_gt_gt_c ai_audiencia_da_tv>. Acesso em: 28 dez. 2013. 
Os diversos grupos de interesse presentes na sociedade disputam a inclusão ou exclusão de temas na agenda, bem como sua hierarquização, mas quem ocupa a posição central são os meios de comunicação de massa, conforme tem demonstrado a ampla literatura sobre a chamada agenda-setting (definição de agenda). A mídia é, de longe, o principal mecanismo de difusão de conteúdos simbólicos nas sociedades contemporâneas. [...] os grupos de interesse e mesmo os representantes eleitos, na medida em que desejam introduzir determinadas questões na agenda pública, têm de sensibilizar os meios de comunicação. ${ }^{405}$

A investigação sobre a convergência entre política e comunicação parte de seu conceito.

Panebianco ensina que comunicação política é o “[...] conjunto das mensagens que circulam dentro de um sistema político, condicionando-lhe toda a atividade, desde a formação das demandas e dos processos de conversão às próprias respostas do sistema”. ${ }^{406}$ A complexidade da sociedade atual e o desenvolvimento da mídia reconfiguram o cenário da comunicação política.

Já foram apresentados autores que são referência no tema, como Schwartzenberg, ${ }^{407}$ cuja obra, O Estado espetáculo, considera o Estado um palco teatral que oferece diversão e personagens carismáticos, provocando a despolitização do público. Já a videopolítica de Sartori ${ }^{408}$ analisa as mudanças provocadas nas campanhas na busca de seu enquadramento ao modelo emocional exigido pela televisão, mutação que afeta o debate de ideias e gera o esvaziamento da política. O homo videns de Sartori toma o lugar do homo sapiens, em uma sociedade em que predomina a imagem sobre a palavra.

Rubim entende que esse espetáculo é inerente aos grupos sociais, e isso não deve ser repudiado, mas compreendido nesse novo espaço corporificado na televisão e nas demais mídias que surgem depois dela:

\footnotetext{
405 MIGUEL, Luis F. Representação política em 3-D: elementos para uma teoria ampliada de representação política. Revista Brasileira de Ciências Sociais, São Paulo, vol. 18, n. 51, 2003. Disponível em: <http://www.scielo.br/pdf/rbcsoc/v18n51/15989>. Acesso em: 15 fev. 2011.

406 PANEBIANCO, Angelo. Comunicação política. In: BOBBIO, Norberto. Dicionário de Política. Brasília: Ed. UnB, 1994.

407 SCHWARTZENBERG, R.G. Op. cit.

408 SARTORI, G. Homo videns.
} 
Importa não que o audiovisual tenha se tornado a "língua franca" da contemporaneidade, mas que a televisão, e por extensão a mídia, possa ser considerada um cenário privilegiado da videopolítica.[...] a mídia emerge, portanto, como lugar e ator da política."

Continua Rubim, afirmando que isso não quer dizer a exclusão dos espaços tradicionais de participação e comunicação política, como os comícios e passeatas, apenas que os meios de comunicação se tornam palco da disputa política moderna, “[...] uma nova dimensão pública de sociabilidade, [...] “lugar” essencial de luta política por poderes." 410

Esse palco é ampliado pela Internet, que apresenta um formato interativo, imediato, instantâneo e transparente. Os meios de comunicação representam uma instituição fundamental para a democracia, sistema pelo qual os mandatários têm o dever de comunicar e justificar suas escolhas e decisões. Os meios de comunicação permitem ao cidadão conhecer esse posicionamento dos representantes eleitos, além de poder circular pela estrutura e funcionamento do próprio Parlamento. A força da Internet está “[...] na sua habilidade de superar as barreiras que limitam o acesso de uma enorme massa de informações para os consumidores comuns. [...] A indústria da informação é cada vez mais dependente das ferramentas de distribuição da Internet.”411

De fato, a Internet ampliou as dimensões da cidadania, que possui um novo lócus de atuação política, diversos e alternativos mecanismos de controle e atuação, e novas formas de sociabilidade. Nessa "sociedade em rede", ${ }^{412}$ o processamento e a partilha de informações são um modo de geração de riqueza. O exercício da cidadania e o desenvolvimento político, cultural e econômico dependem da habilidade informacional dos indivíduos, tanto para agir no campo político como para perceber as mudanças sociais. Conhecer o funcionamento das mídias, mais especificamente, das mídias eletrônicas, e compreender a gestão da informação e comunicação constituem

\footnotetext{
409 RUBIM, Antonio A. C. Op. cit., p. 54.

410 RUBIM, Antonio A. C. Op. cit., p. 51.

411 DIZARD, Wilson. A nova mídia: a comunicação de massa na era da informação. 2. ed. Rio de Janeiro: Jorge Zahar, 2000, p. 25.

412 CASTELLS, Manuel. A sociedade em rede. A era da informação: economia, sociedade e cultura, v. 1. Trad. Roneide Venancio Majer. 6. ed. São Paulo: Paz e Terra, 2012.
} 
uma das mais determinantes formas de poder da modernidade. ${ }^{413}$ Os impactos dessa transformação, obviamente, atingem o processo eleitoral.

Gomes assim define campanha eleitoral:

O conjunto de ações comunicativas, desenvolvidas durante um período de tempo previamente estabelecido, geralmente sob a direção estratégica de um comando único e com a intenção de atingir a determinados objetivos eleitorais em favor de uma organização política, representada por seus candidatos. ${ }^{414}$

É nesse contexto que estão os sites de campanhas eleitorais, ambientes nos quais ocorre a propagação das mensagens políticas e que facultam a interatividade algo novo dentro dessa engrenagem -, condição que aproxima os agentes políticos e os agentes sociais, fortalecendo e ampliando o espaço público democrático.

A cada quatro anos, acontece uma mudança na programação dos canais da televisão pública, pois são veiculadas as campanhas eleitorais, e os eleitores terão que conviver com os discursos, imagens de políticos, os debates de ideais e alguns confrontos verbais mais agressivos. As campanhas são embates discursivos complexos. Decifrar os contratos comunicacionais e os argumentos teóricos é o primeiro passo para entender a dinâmica da disputa entre os candidatos aos principais cargos políticos do país.

O Brasil, por sinal, é destaque no cenário mundial das campanhas eleitorais, ${ }^{415}$ não só pela efetividade e rapidez do sistema de urna eletrônica e apuração de votos, mas pelas campanhas em si, reiteradamente merecedoras de prêmios internacionais do setor. O marketing político floresceu com força, no país, combinando pesquisas de opinião e

413 CASTELLS, Manuel. A Galáxia Internet: Reflexões sobre a Internet, os negócios e a sociedade. Trad. Maria Luiza X. de A. Borges. Rio de Janeiro: Jorge Zahar, 2003.

414 GOMES, Neusa Demartini. Formas persuasivas de comunicação política. 2. ed. Porto Alegre: EDIPUCRS, 2001, p. 59.

415 “A profissionalização das campanhas eleitorais responde a esta nova circunstância e aos requisitos da tela, ainda que suas "linguagens" não estejam confeccionadas em plenitude, como se observa, de forma escancarada, com relação à Internet. O autor comenta sobre os vários estudos em andamento que investigam a relação da política com as novas mídias, dentre elas, a Internet. Ressalta Rubim o aspecto fundamental dessa averiguação, "pois nelas ainda não se formatou e convencionou um "padrão gramatical” próprio, adequado ao suporte sociotecnológico já existente, ele mesmo em dinâmica mutação.” RUBIM, Antonio A. C. Eleições e (Idade) Mídia. In: BARROS FILHO, Clóvis de. Comunicação na pólis: ensaios sobre mídia e política. Petrópolis, RJ: Vozes, 2002, p. 55. 
tecnologia na preparação das campanhas, as quais assumem custos altíssimos. Saber vender a imagem do candidato não significa que as campanhas investem em aspectos ideológicos e programáticos das candidaturas. Muito pelo contrário. As campanhas destacam a qualidade do produto, ou seja, o candidato. Erro mais grave se verifica quando, além disso, o marqueteiro decide formular políticas públicas por conta própria. ${ }^{416} \mathrm{O}$ poder do marketing, portanto, pode ser muito preocupante, por criar políticos e administrar medidas de forma irresponsável, porém, que pode influenciar o eleitor. ${ }^{417}$ Como enfatiza Lembo: "Ser político é exercer uma tarefa missionária e uma ação pedagógica. Não é político o populista fanfarrão, deixa de ser político o que se dobra a qualquer instituição ou adversidade.” ${ }^{418}$ Infelizmente, essa é uma lição que precisa ser incessantemente repetida no Congresso.

Além disso, percebe-se que muitas das mensagens veiculadas por um candidato possuem conteúdo similar às de outros competidores da disputa política. Isso afeta igualmente o eleitor indeciso ou sem ideologia alinhada que, sem reconhecer diferenças, acaba votando em qualquer candidato e deixando de dar atenção ao debate político, por entender que não haverá mudanças significativas. ${ }^{419}$ Isso aprofunda a apatia e afasta 0 eleitor do debate público.

Por outro lado, as mídias oferecem vasta quantidade de informações sobre os candidatos, revelando seus ideários políticos e projetos de governo, assuntos que se tornam temas de conversa, nos círculos de convivência dos cidadãos. Esse fenômeno de agendar os temas da sociedade midiatizada é explicado pelo agenda-setting, ${ }^{420}$ uma pauta de fixação dos temas políticos que serão considerados de interesse coletivo e que

416 Por exemplo, o projeto de Celso Pitta de implantar o meio de transporte denominado “fura-fila”, um dos principais motes do candidato quando de sua campanha para a Prefeitura da capital paulista.

417 Muitas vezes, as pessoas querem acreditar no que veem, e não distinguem o falso do real. Arendt não hesita em afirmar, entretanto, que "[j]amais alguém pôs em dúvida que verdade e política não se dão muito bem uma com a outra, e até hoje ninguém, que eu saiba, incluiu entre as virtudes políticas a sinceridade. Sempre se consideraram as mentiras como ferramentas necessárias e justificáveis ao ofício não só do político ou do demagogo, como também do estadista”. ARENDT, Hannah. Verdade e política. In: Entre o passado e o futuro. 3. ed. São Paulo: Perspectiva, 1992, p. 283.

418 LEMBO, Cláudio. Ética e poder. In: ZILVETI, Fernando A.; LOPES, Sílvia (Coord.). O regime democrático e a questão da corrupção política. São Paulo: Atlas, 2004, p. 83.

419 GOMES, Neusa Demartini. Op. cit., p. 113.

420 O primeiro trabalho publicado sobre o tema é o de McCombs e Shaw, chamado The agenda-setting function of mass media, de 1972). 
é estabelecida pela mídia. Lippman, em seu clássico Public Opinion, ${ }^{421}$ sustenta que o conhecimento das pessoas sobre o mundo exterior e sobre sua própria existência é formado pela seleção de símbolos feita pela mídia. Os meios de comunicação modelam essas imagens, ao selecionar e organizar símbolos de um mundo real. Com isso, afirmase que os meios de comunicação representam um ator intermediário entre esfera política e cidadão, tornando-se capazes de determinar a agenda pública.

De fato, a dramatização de alguns acontecimentos e a adoção de uma dinâmica acelerada na transmissão da notícia, além da personalização do conteúdo, conseguem determinar o debate. Em acréscimo, essas notícias são observadas de perto pelos responsáveis pelas campanhas políticas, os quais reproduzem essas mesmas notícias para o fim que melhor lhes aprouver, formando a realidade política. Resta saber se as novas tecnologias serão capazes de alterar essa agenda, exigindo matérias mais reflexivas e pautas mais pertinentes com os problemas reais da sociedade - ou se apenas serão mais uma forma a servir o agenda-setting.

Se a televisão - e não só ela, mas todos os instrumentos da mídia - oferece tantas possibilidades de participação e ingerência política, configurando-se como um importante ator em processos pelos quais a sociedade se repensa e se transforma, não parece demais construir limites e regulações que lhe imponham prestação de contas e responsabilização política. Comunicação e política devem caminhar juntas, questionando políticas públicas e trazendo novas propostas para efetivas mudanças e melhorias para todos. A construção de uma democracia passa pelo diálogo e pela análise profunda da sociedade, suas instituições, cultura, história, seu povo. Não é um processo simples, por isso requer cuidado, empenho, participação e interesse da sociedade. A função do espaço público e da comunicação política é criar um laço entre comunicação e democracia, implementando ferramentas para conceber um modelo de democracia de massas mais responsável e transparente.

Fundamental para a renovação da democracia representativa via Internet é a atuação estatal, no sentido de reverenciar a comunicação pública online para garantir maior proximidade e interatividade com os cidadãos, deixando de se posicionar como um Estado arrecadador - que posiciona o cidadão como um mero contribuinte ou

${ }^{421}$ LIPPMAN, Walter. Public opinion. New York: The MacMillam Company, 1960. 
consumidor - e restituindo-lhe o papel de soberano, que intervém nos negócios públicos por intermédio de fóruns eletrônicos e plebiscitos online, conquistando um espaço democrático sem precedentes.

\subsection{Disputa eleitoral: igualdade, liberdade e regulamentação}

O desenvolvimento dos direitos do homem remonta à Antiguidade, quando havia a defesa da superioridade do direito natural sobre as leis positivas existentes. Por direito natural entende-se um direito de aplicação imediata, que obriga o legislador. Aristóteles, na sua concepção de Estado, demandava, em nome da justiça, que todos fossem tratados de forma igual, sendo que seu modelo de justiça corresponde a dar cada um o que é seu, segundo uma certa igualdade. ${ }^{422}$ Fleiner-Gerster elucida que os estoicos “[...] descobriram a íntima relação entre a justiça e o princípio da igualdade.»"423 Em consequência, afirma-se que o ideal isonômico é reflexo dos valores construídos pelos grupos sociais ao longo da história dos direito humanos, com tratamento iniciado no campo do direito natural e posteriormente inserido nas normas de direito positivo, representando a espinha dorsal da democracia.

Durante a Idade Média, a desigualdade dá o tom predominante, em um intervalo histórico de acentuadas desigualdades. A sociedade era dividida em senhores feudais e servos, estes fortemente explorados por aqueles e ainda tendo que pagar-lhes tributos para poder usar a terra. A decadência do sistema feudal, o aparecimento das cidades, as guerras e uma série de transformações sociais desencadeiam o processo de surgimento do Estado moderno.

Hobbes preconiza, em seu Leviatã, a radical igualdade natural entre os homens em seu estado de natureza, igualdade física e espiritual, que faz com que os anseios sociais sejam os mesmos, possibilitando a todos atingir os fins desejados. Assegura:

422 A ideia é apenas mostrar que o conceito de igualdade já era discutido na Antiguidade, sem entrar na análise detalhada da doutrina aristotélico-tomista, que envolve igualdade absoluta e proporcional e o conceito de justiça corretiva. ARISTÓTELES. Ética a Nicômaco. Trad. Julián Marias. Madri: Centro de Estudios Constitucionales, 1999.

423 FLEINER-GERSTER, Thomas. Op. cit., p. 100. Apesar da ligação com a escola estoica, os romanos não entendiam a igualdade entre os homens como um dever jurídico, mas como um dever moral. Por isso até era possível a convivência com a instituição da escravatura. 
Quanto às faculdades do espírito, encontro entre os homens uma igualdade ainda maior que a da força. Porque a prudência nada mais é do que a experiência, que um tempo igual concede igualmente a todos os homens, naquelas coisas a que igualmente se dedicam. ${ }^{424}$

Era, entretanto, exatamente desse direito natural a todas as coisas que surgiria a desconfiança e o desejo de possuir o que era de outro. Com o perigo sempre iminente de se ver privado de um bem ou da própria vida, nasce um estado beligerante, ${ }^{425} \mathrm{com}$ a guerra permanente de todos contra todos. A sociedade não buscava o bem comum, mas apenas a preservação dos direitos individuais naturais. É erigido o Leviatã, com a transmissão de direitos para o soberano, no intuito de se obter a paz e a preservação da sociedade.

Esse pacto de renúncia ou transmissão de um direito só é possível em função de existir a igualdade entre os homens, isto é, é a semelhança entre eles que garante o cumprimento do pacto.

Rousseau, por sua vez, elabora um pensamento com base, inicialmente, no estado de natureza, no qual o homem se encontra sozinho, até formar as primeiras aglomerações familiares e sociais que identificam o estado selvagem, sem grande competição entre os homens. A situação se altera com o estado social, onde há a disputa por aquilo que pertence não a todos os homens, mas a alguns deles. Assim, os homens surgem em um ambiente de igualdade natural entre todos, com foco na subsistência, até que o advento da propriedade privada faz florescer a rivalidade e a disputa entre os homens. Advém a necessidade de um contrato, que atenua a desigualdade e coloca limites aos anseios humanos, ${ }^{426}$ com a simultânea preservação dos direitos individuais. O contrato social torna os homens perfeitamente iguais.

\footnotetext{
424 HOBBES, Thomas. O Leviatã, ou matéria, forma ou poder de um estado eclesiástico e civil. São Paulo: Martins Fontes, 2008.

425 HOBBES, Thomas. Op. cit., cap. XIII, p. 109.

426 ROUSSEAU, Jean-Jacques. Discurso sobre a origem e os fundamentos da desigualdade entre os homens. São Paulo: Nova Cultural, 1999. Nessa obra, o autor inicia o desenvolvimento da ideia do contrato social.
} 
Locke elabora teoria em consonância com o direito natural. O indivíduo possui direitos naturais inalienáveis, ${ }^{427}$ dos quais não pode abrir mão. Os homens não cedem seus direitos a um soberano, como entendido por Hobbes, eles cedem parte de seus direitos para a maioria, apenas aquilo que for necessário para efetivar o bem comum. É tão somente nesse momento que os homens abdicam da igualdade e liberdade do estado de natureza para poder viver em sociedade, podendo aproveitar de um ambiente melhor, no qual a propriedade - que é anterior ao próprio Estado e não deve sofrer nenhum tipo de intervenção desse ente - é preservada. ${ }^{428}$

Quem governa e quem é governado? Para Locke, a resposta está na racionalidade, critério a ser utilizado como fundamento de exclusão política nos regimes políticos liberais que aparecem mais tarde.

A desigualdade no acesso aos direitos políticos é tratada por Kant quando se refere ao sufrágio, na obra $A$ paz perpétua: “[...] quem tem o direito de voto nesta legislação chama-se um cidadão (citoyen), isto é, cidadão do Estado, e não cidadão da cidade (bourgeois)”, ${ }^{429}$ sendo exigida a qualidade de homem adulto e proprietário de bens, apto a se manter, para gozar do direito de voto.

Benjamin Constant empreende esforço para alterar o paradigma das instituições políticas antigas, ressaltando o valor das instituições modernas, ${ }^{430}$ e é em ensaio de 1805 que o aclamado autor aponta as etapas históricas para se alcançar a igualdade natural: a abolição da escravatura política (ou teocracia), da escravatura civil, feudalismo, e, finalmente, a extinção dos privilégios da nobreza. A história cria as condições necessárias para promover o progresso e, simultaneamente, ocorre o aperfeiçoamento moral dos homens, o que corresponde à tendência para a igualdade. $\mathrm{A}$ descoberta da igualdade dentro de cada um só é possível com esses avanços históricos,

\footnotetext{
427 "Dado que os homens, por natureza, são livres, iguais e independentes...” LOCKE, John. Segundo tratado sobre o governo civil. Trad. Magda Lopes e Marisa L. Costa. Petrópolis: Vozes, 2005, p. 95.

428 LOCKE, John. Op. cit., p. 131.

429 KANT, I. A paz perpétua e outros opúsculos. Trad. A. Mourão. Lisboa: Editora 70, p. 80.

430 CONSTANT, B. Op. cit.
} 
ou seja, não há necessidade nem mesmo de uma ingerência política, pois o processo é inevitável. ${ }^{431}$

A compreensão da existência de um princípio da igualdade como parte do processo histórico também está presente na visão tocquevilliana da América. A decadência da nobreza, o fortalecimento das atividades comerciais, a ascendência da burguesia, o fim da determinação da classe em função do critério do nascimento provocam a tendência natural e inoponível da história em desenvolver condições de igualdade entre os homens. ${ }^{432}$

Os grandes filósofos e pensadores que surgem em seguida e formam o pensamento político e a democracia modernos, como Stuart Mill e Karl Marx, Bentham e Paine, Pareto ou Max Weber, corroboram a ideia de que a igualdade entre os homens e a igualdade jurídica possuem uma natureza transitória. Mesmo com posições tão distintas - alguns enfatizando o voto censitário ou estabelecendo um processo de trabalho político prévio, por exemplo - fato é que o valor da isonomia se desenvolveu em um processo cada vez mais inclusivo, o que continua sendo fundamental para o aprimoramento democrático. O entendimento de que os cidadãos possuem capacidade e autonomia para contribuir para as decisões comunitárias e impactar as políticas públicas que irão regê-los abre um novo horizonte para a definição do pertencimento a um grupo social e para a participação no espaço público. As condições que reforçam a legitimidade dessas conquistas são os direitos políticos, civis e sociais firmados em uma Constituição, lei maior de um Estado que impulsiona o desenvolvimento e promove a igualdade social.

No caso brasileiro, a Constituição prevê, em seu art. $5^{\circ}$, que todos são iguais perante a lei, sem distinção de qualquer natureza, e “[...] assegura a igualdade e a justiça

431 Referimo-nos ao ensaio "De la perfectibilité de l'espèce humaine”, no qual estampa o pensamento: “Ces quatre révolutions, la destruction de l'esclavage théocratique, de l'esclavage civil, de la féodalité, de la noblesse privilégiée sont autant pas vers le rétablissement de l'égalité naturelle. La perfectibilité de l'espèce humaine n'est autre chose que la tendance vers l'égalité. Cette tendance vient de ce que l'égalité seule est conforme à la vérité, c’est-à-dire aux rapports des choses entre elles et des hommes entre eux. L’inégalité est ce qui seul constitue l'injustice”. CONSTANT, Benjamim. Mélanges de littérature et de politique. Disponível em : <http://gallica.bnf.fr/ark:/12148/bpt6k1113078.>. Acesso em: 24 dez.2013.

432 TOCQUEVILLE, Alexis de. Op. cit. 
como valores supremos de uma sociedade pluralista”. ${ }^{433}$ No campo eleitoral, a Constituição fixa como norma estruturante o princípio da máxima igualdade entre os candidatos.

A desigualdade vertical está presente na democracia moderna de modo evidente, pela influência que alguns cidadãos possuem sobre outros. As desigualdades na capacidade de influência política violam condições igualitárias de partida.

Muñoz desenvolve trabalho intitulado La igualdad de oportunidades em las competencias electorales, ${ }^{434}$ no qual aproxima o princípio da igualdade de oportunidades com o direito eleitoral.

Esse princípio aparece na jurisprudência alemã posterior à Lei Fundamental de 1949, ao dispor que aqueles envolvidos no processo de escolha política devem ter as mesmas possibilidades, durante o debate e o processo eleitorais. Canotilho, ao abordar o tema, entende que o princípio faz parte do processo eleitoral justo, ${ }^{435}$ o qual reconhece aos partidos as mesmas possibilidades de participação e ingerência na vontade popular.

Já na perspectiva de Muñoz, o princípio da igualdade de oportunidades no âmbito eleitoral vai ao encontro dos princípios constitucionais espanhóis. O pluralismo político e a liberdade de criação de partidos possibilita a representação de vários grupos sociais, sejam eles maioria, sejam minoria, ofertando ao cidadão um amplo leque de opções. Junto com a liberdade partidária, coexiste a liberdade do eleitor de participar dos assuntos públicos, de forma direta ou por seus representantes, podendo votar de maneira livre e consciente, sem pressões ou interferências. Para que o eleitor possa votar como realmente deseja, as informações recebidas não podem ser viciadas, pois isso afeta a lisura do processo eleitoral.

Entretanto, conforme já abordado, a mídia é capaz de manipular informações, e o eleitor, muitas vezes, não percebe que a mensagem recebida é inverídica ou se deixa influenciar por pressões econômicas, etárias ou sociais. Para corrigir esse rumo, é

433 BRASIL, Constituição Federal, preâmbulo.

434 SÁNCHEZ MUÑOZ, Oscar. La igualdad de oportunidades en las competencias electorales. Madrid: Centro de Estudios Politicos y Constitucionales, 2007.

${ }^{435}$ CANOTILHO, J. J. Gomes, 2003, p. 301. 
indispensável a firme atuação da legislação eleitoral e a intervenção do poder público, de sorte a garantir a mais pura liberdade do sufrágio e a legitimação democrática. ${ }^{436}$

Escreve, ainda, que o representante eleito representa toda a sociedade e não só o grupo social. Por isso, é exercida uma influência mútua entre candidato e eleitor por meio de um processo de comunicação política entre os membros de dada comunidade.

Portanto, a competição eleitoral está intrinsicamente ligada à liberdade de escolha do eleitor que, por sua vez, é orientada pelo princípio da equidade das condições de competição política.

Diante do exposto, o instituto da reeleição presente no ordenamento jurídico brasileiro, fruto do poder de reforma constitucional, merece pequena análise.

A Emenda Constitucional $n^{0}$ 16, de 4 de junho de 1997, introduziu a reeleição no ordenamento jurídico brasileiro, permitindo que os chefes do Poder Executivo disputem a reeleição para a mesma função, para um único mandato, e no exercício do cargo. Por mais de um século repudiado pela legislação brasileira, ${ }^{437}$ esse instituto acabou sendo adotado por servir como um mecanismo de accountability dos governantes, pelo qual seria oferecida aos eleitores a chance de reavaliação dos representantes eleitos, punindo-os ou acolhendo-os com um novo mandato.

Para seus críticos, todavia, a reeleição atinge o princípio do tratamento igualitário, criando um desequilíbrio entre os candidatos, ${ }^{438}$ afetando, ademais, o princípio da alternância do poder e o da limitação temporal.

A instituição republicana sempre considerou inadmissível a reeleição, por atingir a isonomia exigida entre os candidatos. A desigualdade se faz presente, porque o

${ }^{436}$ Munõz aduz que o princípio em tela influencia todo o Direito Eleitoral e se insere em um "[...] complejo o red de princípios de la legitimación democrática”. SANCHÉS MUNÕZ, O. Op. cit., p. 48.

437 Barreto aponta que, nos 180 anos de vida republicana, sempre houve rejeição ao instituto da reeleição. BARRETO, Lauro. Reeleição e continuísmo. Rio de Janeiro: Lumen Juris, 1998, p. 3.

438 Sobre a reeleição, Carmen Lúcia se manifestou no sentido de que ela não se coaduna com os “[...] paradigmas basilares do sistema, o que configura ilegitimidade constituinte.” ROCHA, Carmen Lúcia Antunes. O processo eleitoral como instrumento para a democracia. Resenha Eleitoral do Tribunal Regional Eleitoral de Santa Catarina, Florianópolis, v. 5, n. 1, p. 67, 1988. 
administrador público assumirá, ao mesmo tempo, o papel de candidato e de chefe da Administração, o que abre espaço para o uso da máquina estatal e influências abusivas do poder público. ${ }^{439} \mathrm{Em}$ acréscimo, o candidato/administrador assume posição privilegiada ao receber maior exposição nos meio de comunicação.

Lowenstein, ${ }^{440}$ aliás, em suas reflexões sobre governos autoritários, afirmava ser antidemocrática a incorporação de vantagens na campanha eleitoral para os partidos do governo. Obviamente, o Brasil não é um país autoritário, mas a ponderação segue a mesma linha, porque os chefes do Poder Executivo, por estarem no cargo, têm vantagem sobre os demais candidatos, o que não deveria ser admitido.

Retomando a lição de Muñoz, o autor explica que o princípio da igualdade de oportunidades possui, além da dimensão tratada anteriormente, uma dimensão negativa, que se refere à limitação da liberdade de expressão, no que tange à liberdade de campanha, devendo o poder público legislar para manter o espírito do princípio em foco, impedindo que alguns candidatos se aproveitem de uma posição de superioridade em relação aos demais.

A informação é fundamental para o exercício da liberdade. É por meio da informação que o indivíduo constrói seu espaço de liberdade. Assim, os direitos de falar, de publicar, de colocar em prática suas experiências para os demais membros da sociedade são vistos como fundamentais para o exercício da liberdade.

Dada sua relevância, os sistemas legais e constitucionais não deixaram de incorporar meios de defesa desse elemento, em sentido amplo, abrangendo liberdade de expressão, manifestação, imprensa, reunião, associação. Nesse sentido, podem ser mencionados vários documentos legislativos, dentre os quais a Declaração dos Direitos

439 Assinala Caggiano: “[...] não há que se ignorar que o pleito presidencial de 2010 foi alvo de múltiplas denúncias quanto à utilização da máquina estatal e dos programas governamentais para a campanha da sucessora do antigo presidente e nem se tratava de reeleição. O uso da máquina e do poder político por parte da força ou do partido político situacionista conforma uma deformação do standard conhecido como free and fair election em qualquer plano eleitoral, independentemente de se tratar ou não de reeleição.” CAGGIANO, Monica Herman S. O cidadão-eleitor, jogador com veto no processo eleitoral democrático - Aspectos polêmicos e peculiares do cenário brasileiro. Eleições gerais/2010. In: INSTITUTO VICTOR NUNES LEAL (Org.). A contemporaneidade do pensamento de Victor Nunes Leal. São Paulo: Saraiva, 2013, p. 288-289.

440 LOWENSTEIN, Karl. Teoría de la Constitución. Trad. Alfredo G. Anabitarte. 2. ed. Barcelona: Ariel, 1976, p. 335. 
Humanos; o Convênio Europeu para a Proteção dos Direitos Humanos e Liberdades Fundamentais; o Pacto dos Direitos Civis e Políticos, de 1966; ou a Convenção Americana de Direitos Humanos, de 1969. ${ }^{441}$

No âmbito das Constituições contemporâneas, a proteção não foi diferente. Seguindo a opção política inserta nos documentos políticos firmados pós-Segunda Guerra Mundial, essas Cartas de direitos ${ }^{442}$ preocuparam-se em assegurar expressamente a liberdade de informação, de expressão e opinião, além do livre fluxo de ideias como liberdades fundamentais dos cidadãos.

No Brasil, o estímulo à livre circulação de ideias, à pluralidade de pensamentos e à promoção do debate está presente em várias passagens da Carta Política de 1988.

Além da já analisada liberdade de expressão e de manifestação, Merlin Clève aponta que a Constituição Federal de 1988 trouxe em seu bojo vários artigos que asseguram os direitos fundamentais da liberdade de comunicação (art. 5, inc. IV e IX) e do acesso à informação (art. 50, inc. XIV). A liberdade de comunicação foi ainda reforçada nos artigos 220 a 224, os quais destacaram o princípio segundo o qual as atividades de divulgação de informações “[...] não sofrerão qualquer restrição”, a não ser aquelas previstas na própria Constituição (art. 220, CF). Clève explica os motivos que conduziram o constituinte brasileiro a assegurar tais direitos:

Tratando-se de uma Constituição aberta, conquanto aponte, como objetivo fundamental da República, dentre outros, a construção de uma sociedade livre, justa e solidária, não há, a não ser em circunstâncias expressamente definidas por razões mais do que justificáveis, lugar para o fundamentalismo, para a intolerância, para o suprimir da argumentação do outro, enfim, para a compreensão da alteridade. Ao contrário, no contexto da Constituição brasileira, há lugar para o livre fluxo de ideias, para a disputabilidade intersubjetiva, para o debate forjador da opinião pública e para a formação da razão pública moldada a partir dos discursos que circulam livremente no espaço público. Aparece aqui, com toda a sua força, a importância da liberdade de imprensa, de expressão, de pensamento, de comunicação.

441 A menção a esses documentos que protegem o direito à informação pode ser encontrada em ALMAZÁN, Jaime. Derecho a la información y derechos humanos. Disponível em: $<$ http://www.itaipem,org.mx/work/resources/LocalContent/379/3/X\%20mesa\%20Derecho\%20info\% 20jaime\%20almazan\%20ok.doc>. Acesso em: 31 maio 2012.

442 A Constituição espanhola assegurou a livre difusão de ideias em seu artigo 20; a Constituição chilena de 1980, em seu item 12 do art. 19; e a Argentina, em seu art. 14, Capítulo Primeiro. 
Emerge aqui, na sociedade tecnológica, a exata significação da informação para os sujeitos, os cidadãos ou consumidores. Sem a liberdade de expressão, os mercados se contaminam, o espaço público empalidece, os sujeitos deixam de ostentar a condição necessária para bem decidir a propósito do que é de seu interesse. ${ }^{4{ }^{3}}$

As normas infraconstitucionais, seguindo a mesma orientação, acolhem o princípio da igualdade de oportunidades no momento eleitoral. O Código Eleitoral, em seu artigo 237, condena o abuso do poder econômico, por interferir na liberdade de voto, enquanto o artigo 256 prevê a igualdade de condições aos partidos, na propaganda eleitoral. A Lei Eleitoral, a seu turno, alude expressamente a esse princípio, tachando as condutas que o atingem.

Há também farta jurisprudência sobre o tema, de que seguem dois exemplos:

ELEIÇÕES 2012 - RECURSO - INVESTIGAÇÃO JUDICIAL ELEITORAL - CONDUTA VEDADA - AFRONTA AO INCISO VI, ALÍNEA "B", DO ART. 73 DA LEI N. 9.504/1997 - PUBLICIDADE INSTITUCIONAL EM PERÍODO VEDADO - DIVULGAÇÃO DE NOTÍCIAS SOBRE OBRAS PÚBLICAS NO SÍTIO DA PREFEITURA - PUBLICIDADE REALIZADA NO PERÍODO PERMITIDO E MANTIDA DURANTE O PERÍODO ELEITORAL AUSÊNCIA DE CONOTAÇÃO ELEITORAL OU PROMOÇÃO PESSOAL - OBEDIÊNCIA AO ART. 37, § 1o DA CONSTITUIÇÃO FEDERAL - PREVALÊNCIA DA NECESSIDADE DE PRESERVAÇÃO DO VALOR EQUITATIVO DA LIBERDADE POLÍTICA E DO PRINCÍPIO DA MÁXIMA IGUALDADE ENTRE OS CANDIDATOS - RESTRIÇÃO AO DEVER DE INFORMAÇÃO DO ART. 37 DA CF/88 - APLICAÇÃO DE MULTA PROVIMENTO PARCIAL DO RECURSO [Precedente: Acórdão TRESC n. 27.886, de 5.12.2012, Relator Juiz Marcelo Ramos Peregrino Ferreira]. ${ }^{444}$

Ementa: RECURSO ELEITORAL. REPRESENTAÇÃO. PROPAGANDA ELEITORALEXTEMPORÂNEA. PRÉCANDIDATOS. PREFEITO E VICE-PREFEITO. FACEBOOK. ILÍCITO CARACTERIZADO. OFENSA AO CAPUT DO ART. 36 DA LEI N. ${ }^{\circ} 9.504$ /97. VEICULAÇÃO DE PRETENSA CANDIDATURA AO CONHECIMENTO GERAL. IMPROVIMENTO. 1. No caso, restou caracterizada a ocorrência de propaganda eleitoral antecipada, eis que as publicações, na rede social facebook, ocorreram em 24/02, 29/02, 09/06 e 21/06/2012, sendo indiscutível que foi conferida aos Representados, posteriormente

443 CLÈVE, Clèmerson Merlin. Liberdade de expressão, de informação e propaganda comercial. Revista Crítica Jurídica, Curitiba, n. 24, p. 258-259, jan./dez. 2005.

444 BRASIL. RE $N^{o}$ 341-67.2012.6.24.0086 - Ação de investigação judicial - 86 a zona eleitoral Brusque, Presidente da sessão: Juiz Eládio Torret Rocha. 
candidatos aos cargos de Prefeito e Vice-Prefeito, nas Eleições 2012, vantagem com relação aos outros possíveis candidatos. 2. Segundo os precedentes do TSE, embora o acesso a eventuais manifestações no facebook (e outras redes de relacionamento) dependa de ato de vontade do internauta que, para tanto, deverá ser cadastrado no citado site, é inegável que aquele é um poderoso instrumento de comunicação social apto a divulgar ideias e informações a um número impensável de pessoas, sendo imensurável sua capacidade de influenciar a disputa eleitoral devido ao grande contingente de usuários daquela rede social. 3. Entendimento pacífico no sentido da possibilidade de violação da lei eleitoral que veda a propaganda extemporânea, bem como do princípio da igualdade entre os candidatos, por meio de mensagens veiculadas em redes sociais na internet. 4. A notoriedade política do $1^{\circ}$ recorrente, que exerceu mais de um mandato eletivo no município em comento, somada aos trechos citados de cunho eminentemente eleitoreiro demonstram a ocorrência da propaganda eleitoral antecipada, vez que explicitam eventual candidatura aos cargos de Prefeito e Vice-Prefeito ao pleito que se avizinhava, de modo a se inferir pretensões diversas que não a mera promoção pessoal ao indicar que a chapa dos recorrentes é "ficha limpa". 5. Recurso improvido. ${ }^{445}$

O alargamento da esfera pública patrocinado pela Internet traz reflexos ao processo eleitoral, ao direito de voto, à relação entre partidos políticos e eleitores e ao discurso político. O uso da Internet nas campanhas já é prática corriqueira e que tem merecido atenção da legislação. A liberdade que ela oferece também se insere na dimensão negativa de Muñoz, nesse confronto entre liberdade e regulamentação, e que, invariavelmente, acarreta a limitação de um direito. Vale lembrar a lição de Carl Schmitt, ${ }^{446}$ em seu $O$ conceito do político, no qual aborda a problemática da equação amigo x inimigo, fazendo a ponderação de que até mesmo as democracias precisam se defender de seus inimigos. Em se tratando da Internet, um veículo de informações transmitidas instantaneamente, não só o princípio da máxima igualdade entre os candidatos precisa ser preservado com muita atenção, mas as posturas violentas, acusações anônimas e a intolerância precisam ser coibidas firmemente, devendo a sociedade participar da regulamentação desses comportamentos. ${ }^{447}$

445 BRASIL. TRE-PA - Recurso eleitoral: RE 60433 PA -Rel. Juiz Mancipor Oliveira Lopes.

446 SCHMITT, Carl. O conceito do político/Teoria do partisan. Trad. Geraldo de Carvalho. Belo Horizonte: Del Rey, 2008.

447 Brito trata da necessidade das regulamentações desse meio, mostrando sua preocupação com o tema: “A regulamentação do uso, os direitos autorais e o conteúdo das mensagens são três pontos básicos na questão da regulamentação da Internet [...] No caso da Internet, uma questão é crucial para cada país, cada governo: onde coibir, quem coloca o material na rede ou quem o recebe?” Uma reflexão sobre a revolução da informação e da comunicação. In: COSTA, Márcia Mello (Org.). De Liberal. 
Por fim, cabe destacar a ressalva de Muñoz sobre essas restrições no período eleitoral. Aduz o autor que as liberdades de expressão, de manifestação e de comunicação podem ser limitadas, desde que não ultrapassado o limite necessário para garantir a efetividade dos princípios estruturantes. ${ }^{448}$

O tópico a seguir destacará algumas regras e limites sobre a propaganda política no direito eleitoral brasileiro, ressaltando as novas abordagens feitas ao uso da Internet.

\subsection{Propaganda política: análise da legislação eleitoral aplicável}

A democracia representativa partidária é o modelo que sintetiza os princípios da igualdade e liberdade, ${ }^{449}$ adaptando-os à conjuntura histórica da época, marcada pela massificação dos direitos democráticos e pela ampliação do direito de sufrágio. Nesse ambiente, os estímulos partidários são imprescindíveis, porque, no Estado contemporâneo, matizado pelo pluralismo, há uma tendência ao agrupamento como uma forma de se alcançar as demandas individuais junto aos centros de decisão política, função esta exercida pelos partidos. García-Pelayo ressalta que

[...] só os partidos podem cumprir a função de transformar as orientações e atitudes políticas gerais vividas por certos setores da sociedade em programas de política nacional [...], [e] converter as necessidades expressas ou latentes e os desejos mais ou menos difusos de parcelas da população em pretensões precisas e concretas. ${ }^{450}$

Outro veículo fundamental nessa atuação são as mídias, inclusive no que tange ao acesso aos meios eletrônicos, que, da mesma forma, conseguem extrapolar esse âmbito individual, propagando postulados democráticos de maneira ampla e eficiente, tentando manter, pelo menos em tese, a igualdade entre os concorrentes, como corolário do ideal republicano e do princípio democrático.

Um olhar sobre ética e cidadania. São Paulo: Mackenzie, 2002, p. 135 Ressaltamos iniciativas como a do Marco Civil da Internet, essenciais para a proteção dos direitos fundamentais na rede.

448 SÁNCHEZ MUÑOZ, Oscar. Op. cit., p. 59.

449 KELSEN, Hans. A democracia. Op. cit., p. 27-28.

450 GARCÍA-PELAYO, Manuel. El estado de partidos. Madrid: Alianza, 1986, p. 77-78. 
A primeira referência expressa à propaganda eleitoral está no Código Eleitoral de 1950 (Lei $\mathrm{n}^{0}$ 1.164/50), que previa que as rádios reservassem duas horas diárias para a propaganda partidária. ${ }^{451}$ As estações de rádio ligadas direta ou indiretamente ao poder público estavam excepcionadas, posto que a propaganda era paga. A tabela de preços era única, o que mostrava alguma preocupação com a igualdade entre os competidores.

Apesar disso, as estações de rádio não eram obrigadas a aceitar a divulgação de todo e qualquer candidato. Como elas eram concessionárias de serviço público, parece evidente que os grupos de oposição ao governo podiam sair prejudicados com a citada falta de obrigatoriedade.

Na época, a oposição era representada pela UDN de Carlos Lacerda, que protestara contra Getúlio Vargas em seu segundo mandato e contra Juscelino Kubitschek, pelo fato de suas campanhas políticas serem vetadas pela rádio e, também, mais tarde, pela TV. Esse embate entre governo e oposição udenista foi o passo decisivo para a adoção da propaganda gratuita, no Brasil. ${ }^{452}$

No ano de 1962, é instituída a Lei $\mathrm{n}^{\circ} 4.115$, que, em seu art. $11, \S 3^{\circ}$, faz a previsão da propaganda política gratuita para os “[...] 60 dias anteriores às 48 horas do pleito de cada circunscrição eleitoral do país”. ${ }^{453}$

Essa lei, entretanto, não eliminava a propaganda eleitoral paga. As duas modalidades de propaganda conviveriam, de acordo com as instruções elaboradas pela Resolução 7.006/1962, do Tribunal Superior Eleitoral.

O primeiro Código Eleitoral surgido no regime de 1964 garante acesso mensal dos partidos ao rádio e à televisão. O período histórico pelo qual passava o país não

\footnotetext{
451 RAMOS, Wolney. Propaganda política. São Paulo: Companhia Mundial de Publicação, 2007, p. 81.

452 ASSUNÇÃO, Monica M. T. Carlos Lacerda: demolidor de presidentes e construtor de um novo Estado. 2011. Dissertação (Mestrado) - Instituto de Ciências Humanas e Filosofia da Universidade Federal Fluminense, Rio de Janeiro, 2011. Disponível em: <http://www.uff.br/dcp/wpcontent/uploads/2011/10/Disserta\%C3\%A7\%C3\%A3o-de-2007-M\%C3\%B4nica-de-Matos-TeixeiraDAssump\%C3\%A7\%C3\%A3o.pdf>. Acesso em: 26 nov. 2013.

453 Disponível em: <http://www.planalto.gov.br/ccivil_03/leis/1950-1969/L4115.htm>. Acesso em: 26 nov. 2013.
} 
favorecia a participação partidária, aparecendo, na Lei 4.737 de $1965,{ }^{454}$ os reflexos dos condicionamentos impostos pelos atos de exceção. O que se pode destacar é apenas esse acesso mensal disciplinado no $\S 1^{\circ}$ do art. 250 da lei:

Art. 250. Nas eleições gerais, as estações de radiodifusão e televisão de qualquer potência, inclusive as de propriedade da União, Estados, Distrito Federal, Territórios ou Municípios, reservarão duas horas diárias, nos sessenta dias anteriores à antevéspera do pleito para a propaganda eleitoral gratuita, conforme instruções do Tribunal Superior.

$\S 1^{\circ}$ Fora dêsse período, reservarão as mesmas estações uma hora por mês, para propaganda permanente do programa dos partidos. (sic)

A Lei 9.601 de 1974 - lei Etelvino Alves - eliminou por completo qualquer tipo de propaganda eleitoral paga no rádio e na televisão. Curiosamente, limitou a propaganda na imprensa escrita a um espaço de $12 \mathrm{~cm}$ de coluna, na qual só poderia ser publicado o nome do candidato, seu número e o seu currículo. ${ }^{455}$ A foto, portanto, não aparecia. Pelo seu excesso de rigor e por criar dificuldades para a elaboração de todas as campanhas, essa lei foi muito criticada e questionada no TSE.

A Lei Etelvino Alves foi um dos passos dados pelo governo Geisel em direção a um afrouxamento das regras da ditadura, um processo que devolveria, de forma gradual, o poder aos civis. A estratégia era recuperar a legitimidade do regime, com o processo eleitoral, enfraquecendo as críticas recebidas de todos os lados, dos opositores, das elites e dos dissidentes que estavam no exterior e lutavam pelo restabelecimento da democracia no país.

A estratégia, no entanto, serviu apenas para fortalecer a oposição, que obteve vitória considerável nas eleições legislativas de novembro de $1974^{456}$ e fez com que os militares mais radicais alterassem, mais uma vez, a legislação eleitoral.

\footnotetext{
454 Disponível em: <http://www2.camara.leg.br/legin/fed/lei/1960-1969/lei-4737-15-julho-1965356297-publicacaooriginal-1-pl.html>. Acesso em: 26 nov. 2013.

455 RAMOS, Wolney. Op. cit., p. 82.

456 "Da soma de votos válidos para o Senado, em um total de 24,5milhões, o MDB obteve cerca de R\$ 14,5 milhões de votos, ou seja, 59\%. Conquistou 16 das cadeiras em disputa, e a Arena, apenas seis.” Disponível em: <http://www1.folha.uol.com.br/folha/especial/2002/eleicoes/historia-1974.shtml>. Acesso em: 26 nov. 2013.
} 
Exsurge no cenário eleitoral a Lei Falcão (Lei nº 6.336/76), redigida pelo então Ministro da Justiça Armando Falcão, introduzindo limitações drásticas ao limite da propaganda eleitoral, no país, com a intenção de obter uma vitória da ARENA nas eleições de 1976 e impedir o debate político nos meios de comunicação.

A Lei Falcão permitia que os candidatos mostrassem apenas seus currículos, fotos e plataformas, na televisão; no rádio, era possível apresentar o nome do candidato, o número de inscrição e o currículo. ${ }^{457}$

O ciclo restritivo imposto pelo governo militar seria completado pelo Ato Institucional no 5 e pelo “pacote de abril”, já focalizados no Capítulo 1. Este último estendia a todos os eleitos as restrições impostas pelo artigo $1^{\circ}$ da Lei Falcão.

A consequência é o fortalecimento da luta pela democracia, capitaneada, dentre outros, por Ulysses Guimarães, líder no Senado, e Franco Montoro, líder na Câmara, ambos do MDB. Foi feito um grande esforço para mobilizar um grande número de pessoas que iriam para as ruas enfrentar os limites traçados pela Lei Falcão, que tornou a propaganda política tediosa e vazia, sem a transmissão de qualquer mensagem política, ${ }^{458}$ e nem mesmo de adjetivos à biografia do candidato. A própria sigla ARENA fica insatisfeita com a Lei Falcão e, no ano de 1979, anuncia comissão para propor uma revisão do Código Eleitoral.

Depreende-se, pois, ser antiga a autorização da propaganda política no ordenamento pátrio brasileiro. Essa liberdade de propaganda deriva da liberdade de expressão e opinião, direitos fundamentais previstos constitucionalmente, e sua regulação é indispensável para garantir a igualdade entre os partidos e candidatos, pois “[...] a liberdade não é atributo exclusivo de alguns, tendo de ser igualmente acessível a todos, adquirindo expressiva dimensão social com o estabelecimento de um ambiente propício ao debate de ideias, ao confronto de opiniões”. ${ }^{459}$

\footnotetext{
457 RAMOS, Wolney. Op. cit., p. 82.

458 As campanhas podem ser vistas no site You tube. Alguns exemplos estão no link a seguir. Disponível em: <http://www.youtube.com/watch?v=Xr0oDVJGLT8>. Acesso em: 26 nov. 2013.

459 RIBEIRO, Fávila. Op. cit., p. 294.
} 
Propaganda é, segundo Fávila Ribeiro, “[...] um conjunto de técnicas empregadas para sugestionar pessoas na tomada de decisão”. ${ }^{460}$ A divulgação das ideias e programas dos candidatos lhes dá a oportunidade de exteriorizar o mandato representativo e partidário e de influenciar a opinião pública, para que consigam conquistar ou se manter no poder.

Joel Cândido escreve que faltou técnica ao Código Eleitoral, que não distinguiu propaganda política, da eleitoral, da partidária, tratadas indistintamente. Ensina o autor, no entanto, que: “[p]ropaganda política é gênero; propaganda eleitoral, propaganda intrapartidária e propaganda partidária são espécies desse gênero”. ${ }^{461}$

As definições de Cândido ${ }^{462}$ são esclarecedoras.

Propaganda eleitoral é um mecanismo de captação de votos usado pelos partidos políticos, candidatos e coligações, pelo qual eles divulgam suas propostas no momento autorizado pela lei, com o objetivo de conquistar cargos eletivos.

A propaganda intrapartidária, como o próprio nome diz, se dá dentro do partido, entre os filiados, sendo um processo de convencimento dos correligionários para a escolha dos nomes que disputarão as eleições.

A propaganda política partidária, por sua vez, promove o partido, sem citar nomes de candidatos, e pode ocorrer em momentos eleitorais ou fora deles, sendo vedada no segundo semestre de anos eleitorais.

Segundo o mesmo autor, os bens jurídicos protegidos pela regulação da propaganda, cujo controle é exercido pela Justiça Eleitoral, são

[...] a própria soberania; a manutenção da ordem pública, da moral e dos bons costumes; o controle do abuso do poder econômico, políticos e do poder de autoridade; a defesa dos direitos e a imposição dos deveres previstos na Constituição Federal, bem como a defesa dos

\footnotetext{
460 RIBEIRO, Fávila, Op. cit., p. 289.

461 CÂNDIDO, Joel J. Direito eleitoral brasileiro. 12. ed. Bauru, SP: Edipro, 2006, p. 153.

462 CÂNDIDO, Joel J. Op. cit., p. 153-154.
} 
princípios fundamentais da forma e do sistema de governo vigentes no País. ${ }^{463}$

Loewenstein ${ }^{464}$ aduz que a propaganda política existe desde o princípio da sociedade estatal organizada, mas se fortalece a ponto de conseguir influenciar a vontade individual, quando se apropria dos meios de comunicação. A propaganda utiliza, de forma adequada, gestual, palavras, objetos, figurino e postura, para influenciar a maneira de pensar daqueles a quem se dirige, ${ }^{465}$ e se beneficia dos mecanismos de comunicação de massa, por conseguir despertar de maneira ainda mais eficiente a emoção dos ouvintes, além de se aproveitar do grande número de pessoas que esses mecanismos atingem simultaneamente.

Para Lowenstein, o candidato é vendido como “[...] una pasta de dientes o jabón”, ${ }^{466}$ pois o objetivo não é informar ou educar o destinatário da mensagem, mas fazer com que a informação fique consumível e palatável, desestimulando o espírito crítico, amenizando resistências e controlando a escolha das urnas, atitudes totalmente indesejáveis em uma sociedade democrática.

Não há, todavia, nenhum enunciado específico a proibir a adoção dessa postura em relação ao cidadão, na legislação brasileira, ${ }^{467}$ porque, se é verdade que a campanha eleitoral deve se estribar no espírito republicano e promover a participação cidadã, também não se pode permitir nenhum tipo de censura ao formato que ela terá, pois isso feriria o princípio democrático e a liberdade de expressão. Os efeitos nocivos da Lei Falcão não devem ser nunca mais revividos. Destarte, as leis que regulam o processo eleitoral devem buscar alternativas que estimulem a cidadania ativa e que coíbam o

463 CÂNDIDO, Joel J. Op. cit., p. 152.

464 LOWENSTEIN, Karl. Teoria de la constitución. Barcelona: Editorial Ariel, 1976, pp. 412-421.

465 Lowenstein conceitua propaganda como "[...] el uso de personas, palavras, objetos, símbolos, o outras técnicas de representación para conducir, hacia los objetivos de los que la manejan, la mentalidade y la conducta de aquellos a los que va dirigida.” LOWENSTEIN, Karl. Op. cit., p. 414.

466 LOWENSTEIN, Karl. Op. cit., p. 415.

467 Tratamento que não é privilégio da política brasileira, já que outros países são igualmente afetados pela mercantilização do discurso político. Tanto é que a campanha eleitoral milionária de Barack Obama para a presidência dos Estados Unidos, em 2008, ganhou o prêmio de anunciante do ano nos Estados Unidos (AdAge), superando a Apple. Em 2009, foi a vencedora do prêmio Grand Clio de marketing. 
abuso de poder econômico, criando, além disso, formas mais rígidas de controle e de fiscalização ${ }^{468}$ do financiamento de campanha. ${ }^{469}$

A propaganda eleitoral possui limites quanto ao tempo, ao conteúdo, ao agente e à forma. ${ }^{470}$ Neste item, serão apontadas algumas regras gerais, mas o escopo principal serão as regras relacionadas ao uso da Internet na propaganda política.

A permissão para a realização da propaganda eleitoral, inclusive para aquela realizada na Internet, ${ }^{471}$ começa no dia 6 de julho do ano da eleição (art. 36 da Lei Eleitoral). A limitação temporal visa a reduzir as despesas eleitorais ${ }^{472}$ e promover melhor organização da estrutura de campanha. No segundo semestre do ano das eleições, é proibida a propaganda eleitoral gratuita para os partidos, vedada igualmente a propaganda paga no rádio e televisão. A infração faz o beneficiário - desde que tenha conhecimento da publicidade - incorrer em pesada multa, ou ao equivalente ao custo de campanha, se este for maior.

A Lei 12.034 de 2009 delimita os eventos que não configuram propaganda eleitoral antecipada, ${ }^{473}$ alterando o art. 36-A da Lei Eleitoral. Assim, a participação de filiados ou pré-candidatos em entrevistas e programas no rádio, TV e Internet, desde

468 Barreto trata do princípio da ampla fiscalização da propaganda, definido pela possibilidade de todos os partidos, coligações e candidatos - e em determinados casos, o eleitor - representar à Justiça Eleitoral em face de propaganda eleitoral em desconformidade com a legislação. BARRETO, Lauro. Manual de propaganda eleitoral. Bauru: Edipro, 2000, p. 24

469 As contribuições não mais favorecem candidatos ou partidos desta ou daquela ideologia - mesmo porque é difícil diferenciar a ideologia dos 32 partidos existentes atualmente. Os financiadores têm feito doações no intuito de obter vantagens em troca, motivados por questões econômicas, e não eleitorais. A influência do poder econômico sobre as eleições desequilibra a competição e desestabiliza a democracia, porquanto discrimina grupos e partidos que não conseguem se manifestar como desejam, em virtude dos altos custos envolvidos, sendo que a participação política dos diversos movimentos sociais deve ser valorizada, bem como a atuação do terceiro setor, capaz de propor políticas transformadoras.

470 Conforme discorrido em momento anterior, nenhuma dessas limitações visa a impedir o normal exercício das liberdades constitucionais. São regras que refletem o poder-dever do Estado de intervir para assegurar a igualdade e equilíbrio na disputa, possibilitando a livre escolha do eleitor.

471 Nesse caso, o endereço na Internet deve ser informado à Justiça Eleitoral e deve ser hospedado, direta ou indiretamente, em provedor estabelecido no Brasil (art. 57-B da LE).

472 O art. 145 da Lei Eleitoral prevê o dia 10 de junho de cada ano eleitoral como o limite para os gastos de campanha dos cargos em disputa. Caso a lei não seja instituída, a definição é feita pelos partidos, que devem informar a quantia para a Justiça Eleitoral.

473 A propaganda antecipada, além de gerar desigualdades entre os candidatos, pode camuflar o abuso do poder econômico e político. 
que não haja pedido de voto, não configura propaganda antecipada. No mesmo diapasão, as prévias partidárias e sua divulgação pelos instrumentos de divulgação intrapartidária, além da organização de encontros em ambientes fechados, pagas pelo partido.

Da mesma forma, não caracteriza propaganda extemporânea a página pessoal do candidato na Internet, desde que sirva para mostrar a rotina do candidato ou sua biografia. Se contiver pedido de voto e indicação do cargo pretendido, será considerada propaganda irregular. ${ }^{474}$

Diversamente do estipulado para a propaganda eleitoral por rádio e televisão, a propaganda veiculada gratuitamente na Internet, seja em qualquer uma de suas plataformas $^{475}$ (sítio eleitoral, blog, sítio do partido ou coligação etc.), não será suspensa no período entre quarenta e oito horas antes até vinte e quatro horas depois da eleição (art. $7^{\circ}$ da Lei $n^{\circ} 12.034 / 2009$ ). Portanto, ficou definido não haver limite temporal para a veiculação de propaganda política pela Internet, ${ }^{476}$ face à dificuldade de controle sobre manifestações de apoio.

Configura-se livre a manifestação de pensamento, sendo expressamente vedado o anonimato no período de campanhas eleitorais, pela Internet ou por qualquer outro meio de comunicação via mensagem eletrônica (art. 57-D da LE). Afinal, o pluralismo

474 “Para que a manutenção de página na Internet venha a caracterizar propaganda irregular é necessário que contenha pedido de votos, menção ao número do candidato ou do partido, bem como qualquer referência às eleições. In: REsp 26286/SP, Rel. Min. Carlos Eduardo Caputo Bastos. Publicado no Diário de Justiça do dia 18 de dezembro de 2006, página, 187. Ou: “[...]. Propaganda antecipada. Divulgação. Texto. Internet. Blog Conotação eleitoral. Presente. [...]. 1. Nos termos da jurisprudência da Corte, deve ser entendida como propaganda eleitoral antecipada qualquer manifestação que, antes dos três meses anteriores ao pleito, leve ao conhecimento geral, ainda que de forma dissimulada, a candidatura, mesmo que somente postulada, a ação política que se pretende desenvolver ou as razões que levem a inferir que o beneficiário seja o mais apto para a função pública. [...] 3. A garantia constitucional da livre manifestação do pensamento não pode servir para albergar a prática de ilícitos eleitorais, mormente quando está em jogo outro valor igualmente caro à própria Constituição, como o equilíbrio do pleito. 4. Divulgada, por meio de página na internet, a candidatura e os motivos pelos quais a candidata seria a mais apta para o exercício do cargo público, é de se reconhecer a prática de propaganda antecipada; [...]”'In: Ac. De 17.3.2011 no R-Rp n 203745, rel. Min. Marcelo Ribeiro.

475 Devido à celeridade das inovações tecnológicas, entende-se que a relação descrita pelo legislador não é taxativa. Se novas formas de comunicação forem criadas para a Internet, poderão ser acrescentadas pela jurisprudência.

476 O art. 39, § 5º , III da LE afirma ser crime a divulgação, no dia da eleição, de qualquer propaganda de partido ou candidato. A solução interpretativa excepciona apenas a propaganda feita na Internet. Em qualquer outro meio, ela será considerada crime eleitoral. 
de ideias é fundamental para a formação e convencimento da opinião do eleitor; por outro lado, ele sofre a devida relativização, para que se conheça quem fez as ofensas e possa haver a acertada responsabilização. Nesse caso, o meio onde se deu a veiculação da notícia terá que arcar com o ônus de exibir a resposta do ofendido. Como exemplos:

Ementa: E $\quad M \quad$ E $\quad \mathrm{N} \quad \mathrm{T} \quad \mathrm{A} \quad-\quad$ RECURSO ELEITORAL. REPRESENTAÇÃO. PROPAGANDA. PLEITO MUNICIPAL. DIVULGAÇÃO DE MENSAGENS EM SITE DE INTERNET. NÃO IDENTIFICAÇÃO DO AUTOR.ANONIMATO. VEDAÇÃO. ART. 57-D DA LEI N. ${ }^{\circ} 9.504$ /97. PUBLICIDADE NEGATIVA. MANIFESTAÇÕES OFENSIVAS. MULTA. SENTENÇA MANTIDA. IMPROVIMENTO. A publicação, em site de internet, de mensagens anônimas de caráter eleitoral, é vedada, nos termos do art. 57-D da Lei n. ${ }^{\circ} 9.504$ /97, sujeitando-se o responsável pela divulgação (provedor de acesso), à sanção de multa. Não sendo possível identificar, efetivamente, a autoria das mensagens, deve-se tê-las anônimas, para efeitos legais, pois não trazem a assinatura do autor, não sendo admissível o uso de pseudônimos como meio de descaracterizar o anonimato, conceituado como abuso da liberdade do pensamento. Restando comprovado que houve a divulgação, pela recorrente, de inúmeras mensagens eletrônicas, de natureza eleitoral, que afetaram candidatos a cargo eletivo, inexistindo a plena identificação dos autores, mas apenas, em alguns, o registro de denominações genéricas (Eleitor, Cidadão Cansado, Interessado), trata-se, pois, de propaganda eleitoral negativa, sob anonimato, o que enseja a responsabilização, nos termos do art. 57-F da Lei n. ${ }^{\circ} 9.504$ /97, por afronta ao art. 57-D da mesma lei. ${ }^{477}$

Anonimato não se confunde com a falta de identificação do responsável, como explica Madruga, cujos dados podem ser obtidos com a identificação do IP - Internet Protocol -, que corresponde ao endereço do computador, ou mesmo com a quebra de sigilo fiscal. Informa também o autor que,

[...] como já decidiu o TSE, a identificação do responsável direto pela divulgação não é elemento essencial para determinar a suspensão da propaganda, não sendo igualmente suficiente a mera "alegação de ser o material anônimo". Há que se demonstrar a "violação das regras eleitorais" e "a ofensa a direito"daqueles que participam do processo eleitoral. ${ }^{478}$

477 BRASIL - TRE - MS - RE $n^{o}$ 259-67.2010.6.12.022 - Publicado em 25/09/2012. Juiz Renato Toniasso.

478 MADRUGA, Sidney Pessoa. Propaganda eleitoral. Espécies. Propaganda antecipada. Propaganda na Internet. In: RAMOS, André de Carvalho (Coord). Temas do direito eleitoral no século XXI. Brasília: Escola Superior do Ministério Público da União, 2012, p. 392-393. 
Os chamados perfis fakes, ou seja, falsos perfis, que denigrem ou beneficiam uma candidatura, pode ser igualmente interpretados como conteúdo político-eleitoral. O candidato que está sendo beneficiado, portanto, deve pedir a retirada do conteúdo da Internet, porque, caso isso não seja feito, o candidato prejudicado pode fazer esse pedido na justiça. Esse perfil também atinge o art. 57-D da Lei no 9.504/97. Assim:

EMENTA - RECURSO ELEITORAL - PROPAGANDA
ELEITORAL - INTERNET - FOTOMONTAGEM - PROPAGANDA
NEGATIVA - PERFIL FAKE NO FACEBOOK - ANONIMATO -
VIOLAÇÃO A REGRA DO ARTIGO 57-D DA LEI N. ${ }^{\circ}$ 9.504/97 -
RESPONSABILIDADE DO PARTIDO - EXASPERAÇÃO DA
PENA NÃO FUNDAMENTADA - REDUÇÃO DA MULTA -
RECURSO PARCIALMENTE PROVIDO. 1. A utilização de um
perfil fake em redes sociais para a divulgação de propaganda eleitoral
visa resguardar o verdadeiro responsável, constituindo, assim,
verdadeira afronta ao artigo 57-D da Lei n. ${ }^{\circ}$ 9.504/97. 2. À míngua de
elementos que indiquem a necessidade de exasperação da pena, a
multa deve ser fixada em seu mínimo legal. 3. Recurso parcialmente
provido. $^{479}$

É cediço que a propaganda eleitoral não pode incidir em nenhum proibitivo legal, não sendo admitida a propaganda que caluniar, difamar ou injuriar qualquer pessoa, ou que atingir órgãos ou entidades que exerçam autoridade pública, casos aos quais está previsto o direito de resposta, que será veiculado no mesmo meio em ocorreu a ofensa. ${ }^{480}$ A lei estatui que possuem legitimidade para exercer o direito de resposta o candidato, o partido político ou a coligação que forem ofendidos. Quem não for candidato ou não fizer parte do processo eleitoral não possui esse direito. Exceção se aplica ao terceiro que não é candidato, mas que foi atingido por acusações inverídicas. Para a proteção de sua honra, a ele também cabe direito de resposta.

Não há prazo certo para o direito de resposta às ofensas geradas na Internet. ${ }^{481}$ Como a Internet não é uma concessão pública, tem-se entendido que, no caso dessa

479 BRASIL - TRE-PA - Recurso Eleitoral $n^{o}$ 146-18.2012.6.16.0147. Juiz relator Dr. Marcos Roberto Araújo dos Santos.

480 O propósito de ofender integra o conteúdo do fato dos crimes contra a honra, é o elemento subjetivo do tipo inerente à ação de ofender. Consequentemente, ele não se realiza se a manifestação sob questão foi feita com o propósito de informar ou narrar um acontecimento (animus narrandi) ou de debater ou criticar (animus criticandi). In: STF- RT 625/374.

481 Na imprensa escrita, o prazo é de setenta e duas horas, contados das dezenove horas da data da edição do meio de propaganda; na rádio ou televisão, o prazo é de quarenta e oito horas, contados da veiculação da ofensa, se tiver ocorrido durante a programação normal; ou prazo de vinte e quatro horas, se a ofensa tiver acontecido no horário eleitoral gratuito em rádio e TV. 
omissão, ela deve ser equiparada à imprensa escrita, sendo que seu prazo para o direito de resposta é de setenta e duas horas. Deve ser ressaltado que ainda não há decisão do TSE a respeito e, portanto, esse prazo pode ser definido em qualquer momento, no melhor entendimento do tribunal.

Uma vez deferido o pedido, determina o art. 15, IV, “a”, da Resolução n. 23193 de 18/12/2009 do TSE, que a resposta seja divulgada no mesmo espaço no qual se deu a ofensa, com o mesmo tamanho de fonte.

Na Internet, a propaganda deverá ser gratuita e não poderá ser veiculada em sítios oficiais ou de pessoas jurídicas, tenham ou não fins lucrativos. A intenção foi coibir o comércio em ambiente virtual, com propagandas focadas apenas em interesses econômicos, distantes dos ideais que envolvem a propaganda política. Também vedada a veiculação em sítios oficiais ou hospedados por órgãos ou entidades da administração pública direta ou indireta da União, Estado, Distrito Federal e Municípios (art. 57-C, “caput”e §§ da LE).

A Lei no 9.504/97 estabelece, no parágrafo único do artigo 57-F, que os provedores de conteúdo ou de serviços multimídia só serão considerados responsáveis pela divulgação de propaganda se a publicação do material for do seu prévio conhecimento.

A definição de provedor dada por Mareei Leonardi é:

O provedor de informação é toda pessoa natural ou jurídica responsável pela criação das informações divulgadas através da Internet.

O provedor de conteúdo é toda pessoa natural ou jurídica que disponibiliza na Internet as informações criadas ou desenvolvidas pelos provedores de informação.

Dessa forma, o provedor de conteúdo pode ou não ser o próprio provedor de informação, conforme seja ou não o autor daquilo que disponibiliza. ${ }^{482}$

482 LEONARDI, Mareei. Responsabilidade civil dos provedores de serviços de Internet. São Paulo: Juarez de Oliveira, 2005, p. 30. Essa diferença é fundamental no âmbito da legislação eleitoral que adota o prévio conhecimento como o elemento definidor de responsabilidade. 
Assim, os provedores de conteúdo, como os blogs, respondem diretamente pelo conteúdo de autoria de seus responsáveis. No caso de material, mensagens e informações produzidos por terceiros, há de se demonstrar o prévio conhecimento do responsável e que ele, sabendo do fato, optou por mantê-lo, mesmo que de forma irregular.

À propaganda eleitoral exercida nos termos da lei não pode ser imposta multa, nem ela pode ser cerceada sob o pretexto de aplicação de poder de polícia, que é exercido pelos juízes eleitorais e por aqueles designados pelos Tribunais Regionais Eleitorais. Com isso, fica vedada a censura prévia dos programas eleitorais exibidos no rádio, televisão ou Internet (art. 41 da Lei Eleitoral, de acordo com as alterações trazidas pela Lei 12.034/2009).

Todavia, se a Justiça Eleitoral entender irregular a propaganda, pode proibir sua veiculação, o que não constitui censura, mas obediência ao princípio da lisura e da legitimidade dos pleitos eleitorais e da igualdade de condições entre os concorrentes. Assim:

Ementa: RECURSO ELEITORAL - PROPAGANDA - TELEVISÃO - PROGRAMAÇÃO NORMAL - CENSURA PRÉVIA - NÃO CONFIGURAÇÃO - CONFORMAÇÃO ENTRE PRINCÍPIOS CONSTITUCIONAIS - OPINIÃO CONTRÁRIA A CANDIDATO COMPROVAÇÃO - MENSAGEM SUBLIMINAR - OCORRÊNCIA - IMPROVIMENTO DO RECURSO. 1 - A aplicação da lei eleitoral não enseja censura prévia ou embargo à livre manifestação de pensamento, liberdade de opinião ou de imprensa, vez que o pretendido é a conformação entre esses princípios e da isonomia dos candidatos; 2 - In casu, o apresentador emitiu opinião contrária à do candidato, ultrapassando os limites da informação e transmitindo ao eleitor mensagem subliminar, o que fere as disposições contidas no art. 45, inciso III , da Lei das Eleições; 3 - Recurso improvido. ${ }^{483}$

Em relação às doações, a Lei no 12.034/2009 alterou o art. 23 da LE e passou a autorizar a doação de pessoas físicas via Internet, por meio dos sites dos partidos e candidatos, além da doação de valores por cartão de crédito. O doador deve ser identificado, e será emitido recibo para cada doação feita.

483 Recurso Eleitoral no 14512 - 25a Zona Eleitoral. Diário de Justiça - Tomo 05 - Data 9/1/2009 página 138/139 - Juiz Haroldo Correia Máximo. 
O desenvolvimento da ciência e a complexidade de novos setores da atividade econômica acontecem, mormente nos dias atuais, em velocidade que supera a possibilidade de o legislador acompanhá-lo, regulando todas e quaisquer situações dele oriundas.

Antes da Lei $n^{\circ}$ 12.034/2009, havia apenas a Resolução do TSE $n^{\circ}$ 22.718/2008 a disciplinar o uso da Internet nas eleições. Essa resolução, entretanto, seguia em muito o disciplinado pela Lei Eleitoral, trazendo poucas novidades ao ordenamento jurídico. Previa, por exemplo, uma página na Internet com a terminação “can.br”, ou com outras terminações, como mecanismo de propaganda eleitoral até a antevéspera da eleição (art. 19 da Resolução) e, em seu art. 18, estabelecia que a propaganda eleitoral na Internet seria autorizada apenas na página do candidato destinada tão somente à campanha eleitoral.

Foi a Lei $\mathrm{n}^{\circ}$ 12.034/2009 que resolveu enfrentar as questões doutrinárias e jurídicas trazidas pelas tecnologias de comunicação, dissipando polêmicas sobre a propaganda eleitoral na Internet. Com essa lei, ficou claro que a limitação da propaganda não pode engessar a atividade política em qualquer meio, nem na Internet, e que se deve buscar sempre uma forma de equilibrar as liberdades constitucionais com o direito do cidadão de obter uma informação objetiva, afastando abusos, perseguições e tratamentos privilegiados.

Por evidente, a crescente evolução dos meios de comunicação continuará a provocar mudanças na seara eleitoral, com o surgimento de casos concretos a serem julgados pelos tribunais, garantindo o voto livre e o avanço da democracia.

\subsection{Limites jurídicos ao uso da Internet nas campanhas eleitorais: propostas}

O rápido desenvolvimento dos meios de comunicação e a convergência digital $^{484}$ introduzem novas dinâmicas nas práticas sociais e ampliam as formas de

\footnotetext{
484 De acordo com Jenkins, atravessamos um período de convergência dos meios de comunicação, processo que, ao interagir com os consumidores, direciona-os para uma lógica consumista. Mas a própria convergência, aliada à inteligência coletiva e à cultura participativa, torna o consumidor mais exigente e bem informado, o que obriga as indústrias a mudarem de estratégia para atender a esses consumidores com perfil mais ativo. É um processo que une tecnologia e cultura e que pode,
} 
interação. No campo da política, as novas tecnologias de informação e comunicação permitem a entrada de novos atores no jogo democrático e criam diversificados mecanismos de atuação. Naturalmente, essa realidade afeta as instituições da democracia representativa, além do direito eleitoral que, por ser dinâmico, precisa acompanhar as evoluções políticas, sociais e culturais, aprimorando suas leis em busca de constante aperfeiçoamento.

A legislação eleitoral brasileira sofreu grande impulso com as alterações introduzidas pela Lei $\mathrm{n}^{0}$ 12.034/2009. Por ocasião do último pleito eleitoral, alguns analistas até mesmo previam que a Internet representaria a grande novidade nas eleições brasileiras, a estrela principal a obliterar os demais atores e políticas tradicionalmente vistas no palco eleitoral. Assim, as novas mídias - websites pessoais, blogs de políticos e e-mails - seriam intensamente usadas nas campanhas, assim como ocorreu nas eleições norte-americanas, substituindo as mídias tradicionais e influenciando a opinião pública e os resultados das votações. Desde então, a relação entre eleição e participação política tem sido um dos temas mais observados pelos analistas.

Se levado em conta o perfil do brasileiro e sua particular preferência pelas mídias sociais, ou o uso crescente de smartphones, bem como a quantidade de mensagens trocadas por celular, o cenário acima parecia razoável e plausível. A Internet seria a arena política a complementar esse conjunto de relações sociais.

As modificações trazidas pela Lei $\mathrm{n}^{0} \quad 12.034 / 2009$ definitivamente representaram um passo no sentido de harmonizar o uso da Internet ao processo eleitoral e corroborar o painel acima, aproximando os cidadãos do debate político. Contudo, por evidente, a lei não esgota os temas relacionados à propaganda eleitoral que merecem regulação, ficando aqui algumas propostas de aprimoramento da lei, no sentido de incrementar o uso da Internet nesse momento eleitoral.

Primeiramente, é importante que haja regras definidas para as campanhas eleitorais. Oportuno é notar que, todavia, o controle de conteúdo que tem sido feito pela Justiça Eleitoral provoca mitigação da liberdade de expressão. 
Como já anotado, a liberdade de expressão é um direito de várias facetas, que pode colidir com outros direitos fundamentais, como o direito à honra ou à imagem, dentre outros. A superação desses confrontos de direitos faz emergir o princípio da proporcionalidade, porquanto o ordenamento jurídico deve apresentar-se harmônico e coeso. O analista jurídico, ao aplicar esse princípio, deve observar a conformidade, necessidade e proporcionalidade em sentido estrito. ${ }^{485}$

A conformidade exige a adequação entre os fins e os meios, ou seja, a exteriorização da manifestação deve ser coerente, sem abusos ou excessos, dentro dos limites do razoável. Deve haver, além disso, a necessidade da restrição, que deve ser indispensável para proteger um direito em detrimento de outro. Por fim, a proporcionalidade em sentido estrito, que permite ao juiz colocar os dois direitos lado a lado, analisando com profundidade o bem jurídico que deve prevalecer na condição posta, chegando a uma solução que atenda aos princípios democráticos estabelecidos no texto constitucional.

Para atingir esse resultado, a análise do bem jurídico, do núcleo essencial de cada direito é fundamental para a resolução do conflito, levando sempre em conta os elementos da situação concreta. O bem jurídico é um conceito da dogmática que visa à limitação do poder do Estado, devendo ser extraído de uma ordem de valores da sociedade. Assim, por exemplo, se a liberdade de expressão macula a honra ou privacidade, pode, a depender do caso concreto, sofrer limitação.

No caso do Direito Eleitoral, o que se opõe à liberdade de expressão é a liberdade do eleitor, um direito metaindividual, ${ }^{486}$ que, apesar de sua natureza coletiva, não perdeu a essência de direito individual. E, ao cotejar essas duas liberdades, a Justiça Eleitoral tem-se mostrado cada vez mais limitadora da liberdade de expressão, o que não nos parece ser o melhor entendimento.

485 ÁVILA, Humberto. Teoria dos princípios - da definição à aplicação dos princípios jurídicos. 10. ed. São Paulo: Malheiros, 2009.

486 Previsto no Código de Defesa do Consumidor, art. 81, III. Afirma Grinover que os direitos metaindividuais são direitos subjetivos tradicionais os quais receberam um tratamento coletivo proporcionado pelo Código de Defesa do Consumidor, por serem homogêneos e por possuírem origem comum. PELLEGRINI, Ada. Da class action for damages à ação de classe brasileira: os requisitos de admissibilidade. Revista de Processo, São Paulo, v. 26, p. 11, jan./mar. 2001. 
É sabido que a campanha política não é um ambiente asséptico, no qual desaparecem críticas e comentários negativos. Toda campanha eleitoral apresenta, em algum momento, fatos, versões ou acontecimentos que intencionam desabonar a figura do outro candidato ou partido. Esses fatos nem sempre são verdadeiros, mas são utilizados mesmo assim, como parte de uma regra do jogo eleitoral. É bem verdade que o uso que se faz da liberdade de expressão precisa, no mais das vezes, estar dentro de padrões moralmente ou socialmente aceitáveis. Caso isso não ocorra, sempre cabe questionamento ao Poder Judiciário.

O interesse público, a liberdade de expressão e manifestação e o pensamento político precisam ser prestigiados. Mecanismos de censura ou de licença prévia devem ser afastados. O limite pode ser outro, como o atingimento da honra alheia ou da privacidade do candidato. Todavia, a postura adotada pela Justiça Eleitoral tem sido cada vez mais paternalista e cautelosa, tendo vetado e coibido inúmeras manifestações e opiniões, principalmente quando acontecem em ambiente virtual, sob a alegação de que a rápida disseminação de propaganda com caráter negativo seria mais prejudicial do que a garantia da liberdade de expressão.

Como observado anteriormente, neste capítulo, a relação entre os meios de comunicação e a opinião pública está estabelecida, mas não se pode afirmar que toda e qualquer propaganda influenciará o voto. Pode vir a influenciar, mas nem sempre isso acontece, pois, conforme mencionado, há vários fatores que interferem no momento do voto. Os efeitos bandwagon ou underdog nem sempre são comprovados. Portanto, a primeira ideia que deve ser disseminada é de que haja uma regulação mais natural da liberdade de expressão, sobretudo no que tange às manifestações feitas na Internet. O Direito Eleitoral é fragmentário; desse modo, não é qualquer mentira, invenção ou ofensa que é capaz de atingir o eleitorado. E aquele que pratica a ofensa, da mesma forma, não pode ter garantia absoluta de que o saldo de votos de sua atitude lhe será favorável ou não.

Assim, defende-se que, no cotejo entre liberdade de expressão e liberdade do eleitor, a primeira deva ser valorizada, ampliada e promovida, porque dela advêm o pluralismo de ideias, o direito de informar e ser informado, o direito de externar as opiniões e teorias que permitem o debate crítico e o revigoramento da democracia. Sem 
abusos, sem excessos. Mas, para isso, existem medidas legais que podem ser adotadas $a$ posteriori, e não antes de a manifestação ser feita.

Demais disso, é importante entender a mutação do fazer política.

A Internet deve estar cada vez mais aberta à propaganda eleitoral e vice-versa. A Internet é multidirecional, descentralizada, possui protocolos abertos, por isso é tão diferente das mídias mais utilizadas até agora. Mas, antes de tudo, ela é um meio. O que dita os processos e políticas democráticos e eleitorais é a forma como esses meios e instrumentos são usados, e o que eles podem fazer, em termos concretos. As características da Internet devem ser vistas como uma forma positiva de estimular a participação cidadã, e não como um ambiente desencadeador de injúrias, calúnias e difamações.

A modulação das decisões da Justiça Eleitoral e sua tendência a proteger o candidato, tirando sites do ar e aplicando multas pesadas a campanhas negativas divulgadas na Internet provocam um evidente chilling effect ${ }^{487}$ no cidadão que deseja divulgar informações, debater, opinar e ajudar a desenhar as instituições sociais. Afinal, se o cidadão sabe que pode sofrer graves punições, que sua página na Internet pode ser retirada do ar, que ele corre o risco de pagar altas quantias em multas, por que debater ou expor ideias? Isso inibe a liberdade de expressão. Desse modo, os tribunais devem atentar a essa realidade e discutir esse assunto de maneira mais comprometida, pois falta um debate qualificado sobre o valor da liberdade de expressão.

Em assim sendo, acredita-se que não deveria haver nenhum tipo de limitação temporal ao uso dos meios de comunicação virtuais. Vídeos, mensagens, manifestações de apoio, qualquer expressão desse tipo pode, afinal, ser caracterizada como propaganda eleitoral. Portanto, o limite temporal não tem nenhuma eficácia em relação ao cidadão

487 Chilling effect é um termo legal que significa a inibição do exercício de um direito legítimo em decorrência de uma sanção. É muito empregado em casos relacionados à liberdade de expressão ou outros direitos individuais garantidos pela Constituição. Nos Estados Unidos, foi usado pela primeira vez no ano de 1952, no caso Wieman v. Updegraff. Em geral, as leis ou ações ligadas ao termo não chegam a proibir a liberdade de expressão, mas impõem multas ou sanções austeras, no caso de a manifestação ser feita. Disponível em: <http://www.jstor.org/discover/10.2307/1121147?uid=2\&uid=4\&sid=21103187569107>. $\quad$ Acesso em: 25 out. 2013. 
comum. E qual seria o fundamento dessa restrição, na Constituição Federal? Não conseguimos apontar.

Pensamos que o estímulo ao uso ininterrupto da Internet como uma plataforma de debate e promoção de ideias e programas políticos é saudável para a democracia. A limitação temporal pode até caber para partidos e candidatos, porém, não para o cidadão comum, que deve produzir a política e desenhar o retrato da sociedade, formando o quadro que ele entender melhor para o seu grupo social. A linha tênue entre propaganda eleitoral e crítica política é cada vez mais artificial, o que torna artificial também a delimitação do uso das mídias apenas a partir de uma determinada data. Devem ser adotadas medidas que preservem a capacidade do cidadão de participar ativamente do processo político, a qualquer momento. Conter manifestações eleitorais na Internet que pode ser acessada de um computador, tablet, notebook ou smartphone - parece ser, cada vez mais, sem justificativa.

Na mesma linha, poderia ser sugerida a alteração do art. 57-B, inc. IV da Lei $\mathrm{n}^{\circ}$ 13.034/2009 e suas implicações na Lei Eleitoral. O artigo aprovado acertou em ampliar a veiculação de propaganda em sítio do candidato, de partido ou coligação, além de blogs, redes sociais, sítios de mensagens instantâneas e assemelhados. Todavia, vetou a possibilidade de o conteúdo postado ser modificado por colagens, mashup ou outras técnicas afins.

Explica Souza ${ }^{488}$ que mashup é um termo musical pelo qual se misturam uma ou mais fontes e fragmentos de música, mais especificamente música eletrônica, para dar origem a um novo som, batida e melodia. A colagem teria sido cunhada por Georges Braque e Pablo Picasso, para explicar a composição de vários elementos visuais distintos e que recebem um novo formato, criando uma obra de arte visual.

488 SOUZA, Randolph Aparecido de. A estética do mashup. 2009. Dissertação (Mestrado em Tecnologia da Inteligência e Design Digital) - Pontifícia Universidade Católica, São Paulo, 2009. 
Os legisladores entenderam que essas práticas provocariam sérios danos aos candidatos e às campanhas eleitorais, que poderiam sofrer inúmeras modificações, além da dificuldade de apontar a autoria da dessas obras. ${ }^{489}$

Mais uma vez, reportamo-nos à liberdade de expressão. O cidadão deve poder atuar na campanha eleitoral online. Essas são práticas do nosso tempo e que foram vetadas em função de possíveis danos que poderiam causar. São práticas legítimas que deveriam ter sido previstas na legislação.

Vale lembrar a campanha pela presidência norte-americana de 2008. Um vídeo lançado no YouTube ${ }^{490}$ se utiliza do famoso discurso de Barack Obama intitulado Yes, we can. Esse discurso foi musicado, cantado e declamado por vários artistas daquele país, a fim de demonstrar apoio que eles davam à candidatura Obama. A forma artística, criativa e sensível da apresentação do vídeo, no ar até hoje, mostra que essas mídias podem ser usadas de forma útil para a participação política.

A proposta a seguir diz respeito ao art. 57-D da Lei 12.034/2009, que proibiu propaganda paga pela Internet. Entendemos que deveria ter sido autorização para a divulgação de propaganda eleitoral paga na Internet. A lei apontou a falta de parâmetros de equidade na Internet para controlar essas propagandas, e os melhores espaços nos principais provedores e no Google seriam adquiridos pelos candidatos com maior poder aquisitivo. Esse artigo conseguiria inibir abusos de poder econômico e desequilíbrio na propaganda eleitoral.

Não obstante essas relevantes justificativas, o controle de sua efetividade é questionável em um mundo globalizado. Muitos dos serviços de Internet utilizados aqui no país não possuem uma empresa sediada no Brasil, mas no exterior, onde possuem sede, administração, e de onde desenvolvem os trabalhos aqui solicitados. Se houvesse mudança na lei, as empresas brasileiras que desenvolvem publicidade eleitoral poderiam

489 Ainda em andamento, por exemplo, ação proposta por Collor em face da Google Brasil, por divulgar no You Tube vídeos que eram verdadeiras colagens sobre a trajetória do ex-presidente. À época, a Google Brasil retirou os vídeos de circulação, com a exceção de um deles, pelo que lhe foi aplicada multa diária de R\$ 20 mil. O ministro do TSE, Gilson Dipp, concedeu medida liminar em mandado de segurança apresentado pela empresa, determinando que o TRE-AL reaprecie a multa, cujo valor é de R 650 mil. Disponível em: <http://snn-noticias.jusbrasil.com.br/politica/7225541/tre-al-tera-querecalcular-multa-de-r-650-mil-ao-google-por-videos-de-collor>. Acesso em: 28 nov. 2013. 
receber mais investimentos para vender seus trabalhos e gerar empregos no Brasil. Ademais, as empresas brasileiras possuem melhor conhecimento da lei e das sanções a quem não obedece às regras. Isso poderia servir como uma forma de coibir propagandas abusivas, e as sanções seriam mais facilmente aplicadas pela Justiça Eleitoral.

Relevante é apontar que a publicidade na Internet pode ter um preço bem mais acessível que outras mídias. As eleições têm ficado cada vez mais caras, e o candidato tem poucos meses para apresentar seu programa partidário (ou se vender, como preferem alguns). O uso da Internet para esse fim possibilitaria a realização de mais propaganda política, o que, em tese, representa mais discussão e debate de ideias.

Ficou prevista, ainda, a suspensão do serviço do site da Internet, por vinte e quatro horas, caso não sejam cumpridas as disposições que regulam propaganda política. Aqui, o legislador permitiu a aplicação de um poder de polícia que suspende todo o conteúdo de um determinado site por conta da veiculação de uma propaganda irregular. Parece-nos uma medida desproporcional. Afinal, todos aqueles que participarem de sites colaborativos - sites que derivam das informações e notícias divulgadas por várias pessoas, que podem estar nos mais diversos locais - ou que forem usuários de redes sociais que apenas “curtiram” uma propaganda e a replicaram ou mesmo terceiros de boa-fé serão atingidos com a punição.

Poder-se-ia até mesmo frisar que muitos conteúdos formados na rede caracterizam uma assembleia constituída no meio virtual, a qual estaria protegida pelo direito constitucional de reunião. Se esse entendimento ganhar reforço pela jurisprudência, surgiria aqui mais uma tensão entre liberdades e direitos.

Assim, entendemos que a propaganda irregular pode ser retirada ou suspensa, porém, não todo o site, pois o dano causado ao meio de veiculação da informação é maior do que a veiculação irregular em si. ${ }^{491}$

\footnotetext{
491 As sanções, por vezes, extrapolam o limite do razoável, como aconteceu com o diretor financeiro do Google Brasil, Edmundo Luiz Pinto Balthazar, que teve prisão decretada por juiz eleitoral da Paraíba, por conta de um vídeo postado em site de propriedade do Google e que não foi retirado do ar. Disponível em: <http://tecnoblog.net/113771/prisao-diretor-google/>. Acesso em: 7 maio 2013.
} 
O legislador disciplinou, outrossim, que: “[o] provedor de conteúdo e de serviços multimídia só será considerado responsável pela divulgação da propaganda se a publicação do material for comprovadamente de seu prévio conhecimento.”492

Nesse caso, o legislador não foi muito exigente com os critérios a determinar qual o provedor ou serviço de multimídia. Para que seus direitos sejam devidamente preservados, há de se ter mais detalhes sobre esse conteúdo irregular e o endereço eletrônico onde ele se encontra hospedado. Esse conteúdo deveria receber descrição pormenorizada, bem como instruções sobre o dia e a hora em que ele estava disponível para acesso. Do contrário, o artigo em pauta pode gerar irregularidades.

Outra importante mudança que poderia ser implementada pela Internet seria o financiamento privado feito exclusivamente pelas doações de pessoas físicas. Se a lei já possibilita a doação pela Internet e por cartão de crédito, talvez tenha sido aberto um caminho para a tão almejada mudança no sistema de financiamento.

Atualmente, a receita dos partidos políticos provém das doações de pessoas físicas e jurídicas, do fundo partidário bancado pelo governo e das contribuições dos filiados. A maior polêmica gira em torno da possibilidade de doação das pessoas jurídicas, as quais podem doar recursos para o partido que, então, repassa os valores para os candidatos de sua escolha, não havendo a menor transparência sobre o destino das quantias doadas. Como a maior parte das doações é feita por empresas, essa prática acaba estimulando a corrupção, ${ }^{493}$ por criar um vínculo daninho entre partidos, empresas e candidatos. O financiamento privado pela Internet poderia ser uma alternativa a esse constante problema da realidade brasileira. Dele, entretanto, poderia surgir outra questão: identificar até que ponto o cidadão estaria disposto a financiar uma atividade que ele tanto critica e que está em tamanho descrédito.

Por tudo isso, fica a observação de que a Constituição Brasileira, com seus recém-completados 25 anos, mostra-se atual e moderna, defendendo e privilegiando vários direitos fundamentais, acesso à cultura e incentivo ao avanço tecnológico.

\footnotetext{
492 BRASIL. Lei $n^{\circ} 12.034 / 2009$, art. 57-F, parágrafo único.

493 CAGGIANO, Monica H. Salem. Finanças Partidárias. Brasília: Senado Federal, 1983.
} 
De outro lado, os poderes Executivo, Legislativo e Judiciário estão defasados em relação às demandas trazidas pelos avanços tecnológicos. Faltam políticas públicas que promovam o estudo científico e os avanços tecnológicos, bem como a implementação de redes de Internet sem fio por todo o país; faltam leis que protejam a privacidade dos usuários; e há muitos julgados que promovem o cerceamento da liberdade de expressão.

Comportamentos guiados pela má-fé de alguns sempre estarão presentes, e os instrumentos disponíveis na Internet também poderão ser usados para fins perniciosos. Todavia, os juízes precisam transformar essas questões em análises casuísticas, sendo sempre guiados pela liberdade de expressão, visando ao incentivo à participação política via Internet. 


\title{
CAPÍTULO IV - ELEIÇÕES, INTERNET E PARTICIPAÇÃO CIDADÃ
}

\author{
Quem tem janelas \\ que fique a espiar o mundo \\ Francisco Alvim ${ }^{494}$
}

\begin{abstract}
Agendas voltadas para o aprofundamento da democracia parecem estar sempre dirigidas para um modelo que unifique a sociedade civil, diante dos problemas trazidos pelos inúmeros conflitos sociais e pela crise da representatividade. A proposta do presente capítulo é apontar uma possível reconfiguração que se presencia envolvendo os atores da sociedade civil e as novas instâncias de mediação propiciadas pelas tecnologias de comunicação e informação (aqui, pela Internet). Essa relação entre atores e grupos sociais e os novos espaços integrativos ampliam o lócus da participação política, que se depara com novas demandas sociais ao governo e a exigência de uma postura de mudança. Se, na democracia liberal, a representação é caracterizada pela atuação individual, na democracia moderna se afirma o potencial da representação coletiva, capitaneado pela Internet e suas mídias sociais, capazes de possibilitar maior consonância entre as escolhas dos representantes e os interesses dos representados.
\end{abstract}

É evidente, todavia, que ainda há muitos obstáculos ao atingimento dessa lógica, que é complexa, atrai vários grupos, vocaliza diversos interesses e se dissemina de forma muito rápida e, por vezes, sem controle. Ainda não se veem mecanismos generalizados e estáveis que ordenem esses espaços de integração, nem instrumentos que tornem efetivas as condições fundamentais para a democracia, como a prestação de contas e a responsividade, nem tampouco foram definidas sanções claras para quem tumultua o ambiente virtual.

Contudo, o debate se faz presente. Por isso, inicia-se o capítulo com uma reflexão sobre a representação política no seu vínculo primeiro, ou seja, o voto e suas características. Demais disso, cabe indagar quais os problemas enfrentados pela democracia representativa e qual o papel de suas instituições, diante da Internet e dos

494 ALVIM, Francisco. Com ansiedade. In: . Poemas. São Paulo: Cosac \& Naify, 2004, p. 141. 
novos espaços democráticos que essa ferramenta nos franqueia. Antes da verificação pontual de leis e jurisprudência que estão a redefinir o alcance da Internet, na democracia brasileira, será abordado o uso dessas redes sociais e outras ferramentas da Internet, no cenário eleitoral dos últimos anos, trazendo algumas considerações sobre sua capacidade de fortalecimento da cidadania.

\subsection{Democracia representativa e Internet}

A democracia atual é fruto de um longo percurso histórico de desconcentração de poder. Desde Atenas, as instituições se efetivam, impedindo que os poderes fiquem apenas em algumas mãos. Houve naquele momento a compreensão de que a comunidade deveria ser ditada ao gosto dos homens, com regras instituídas por eles mesmos, promovendo a participação dos cidadãos na atividade política.

Os senhores feudais também tiveram sua prerrogativas contestadas, sobrevindo o soberano absoluto que se impõe com sua força militar e concentra o poder antes fracionado entre as estruturas feudais. A economia burguesa se desenvolve e estabelece um sistema de relações contratuais que cinde o poder político do econômico. Irrompem as grandes revoluções liberais, com a tutela da liberdade e igualdade a serem recepcionadas pelo movimento constitucionalista e a consequente limitação da ingerência do poder político na esfera individual.

A democracia evolui em virtude do constitucionalismo e torna-se um suporte viável em função do Estado democrático de Direito. Na democracia moderna, o povo se governa de forma indireta, escolhendo seus representantes por meio do voto, representantes esses que, ao serem eleitos, possuem responsabilidade política e jurídica pelos seus atos. A representação é, pois, o meio que operacionaliza a democracia. ${ }^{495}$

\footnotetext{
495 Przerworsky entende a democracia como “[...] um sistema de resolução de conflitos em que os resultados dependem do que seus participantes fazem, mas nenhuma força tem condições de controlar sozinha os acontecimentos.” PRZEWORSKI, A. Democracia e mercado. Rio de Janeiro: Relume-Dumará, 1994, p. 72. A democracia é retratada como um panorama de incerteza eleitoral, mas de certeza institucional. A participação de diferentes setores e segmentos da comunidade social provoca um clima de permanente beligerância e de amplas incertezas, por isso é fundamental a estabilidade das instituições, que se mantêm em um patamar elevado, alçadas pela Constituição Federal. Nesse sentido, as constituições servem ao desenvolvimento da democracia.
} 
O princípio democrático implica a participação de todos os cidadãos no processo de escolha de seus governantes, por meio do voto universal. Hodiernamente, o sufrágio universal é um elemento comum em todos os regimes constitucionais do Ocidente. $^{496}$

Por outro lado, Jellinek assevera que a manifestação do voto não é capaz de mensurar todos os interesses a guiar o cidadão, naquele momento. Muitos fatores influenciam o voto em um candidato, sendo o programa político apenas um deles. E não será nem mesmo o programa político em sua integralidade. Nem se pode afirmar que o voto, ainda que consciente, mantenha as mesmas convicções, ao longo do exercício do mandato do representante. O voto é fundamental à manutenção do sistema representativo democrático e deve ser preservado na sua autenticidade, impondo-se a coibição de abusos eleitorais, sem, todavia, almejar-se a um sistema eleitoral justo. ${ }^{497}$

A autenticidade eleitoral estriba-se na liberdade do voto e na igualdade do voto. Por liberdade do voto entende-se a ausência de fraudes e coações, bem como a vedação compra de votos. Para ser livre, o voto precisa ainda ser secreto, conforme disciplinado no art. $60, \S 4^{\circ}$ da $\mathrm{CF} / 88$, regra que constitui cláusula pétrea e direito fundamental a guiar as decisões democráticas.

A igualdade do voto, da mesma maneira, está consagrada na Constituição brasileira, em seu art. 14, que assim principia: “A soberania popular será exercida pelo sufrágio universal e pelo voto direto e secreto, com valor igual para todos [...].”

496 Para Lowenstein, a qualificação de Estado de Direito exige a fixação das regras do processo político na Constituição, devendo ser estabelecidos os princípios de Direito Eleitoral como conteúdo essencial desse instrumento, a garantir o vínculo entre cidadãos e representantes. LOWENSTEIN, Karl. Op. cit., p. 163.

497 "El problema de un sistema electoral justo y adecuado no tiene solución. Además, nunca se puede decir con certeza del acto de votar lo que el votante piensa y quiere politicamente. La elección de una persona determinada puede darse por motivos más diversos y de ninguna manera significa la aceptación de un programa determinado en cuanto tal. Además, las elecciones se producen en períodos largos y aunque se dieran en períodos cortos no hay garantía de que en el intervalo entre las votaciones el voto del elector sea el mismo de modo que coincida su expresión con los actos de los representantes.” JELLINEK, Georg. Reforma y mutación de la Constitución. Trad. Christian Förster. Madrid: Centro de Estudios Constitucionales, 1991, p. 74. Manin, da mesma forma, entende que ao eleitor não é imposta a adoção de critérios imparciais a definir seu voto, podendo decidir com base em quaisquer características que lhes pareçam mais adequadas, no ato da votação, mesmo que seus valores não sejam partilhados com os demais. MANIN, Bernard. Los principios del gobierno representativo. Trad. Fernando Vallespín. Madrid: Alianza, 1998, p.170. 
Conforme relatado em momento prévio, o processo eleitoral brasileiro já abrigou o voto censitário em função da renda auferida, durante o Império, excluiu o direito de voto das mulheres, até fins da República Velha, além do analfabeto, das decisões políticas, discriminação corrigida com a promulgação da CF/88.

Ao adotar o princípio da igualdade do voto, ${ }^{498}$ a Constituição Federal reflete o ideal republicano e o tratamento com igual respeito, abrangendo não apenas o standard one man, one vote, mas, ainda, a possibilidade de ingerência sobre as decisões políticas dentro das mesmas condições.

De acordo com Rawls, ${ }^{499}$ os cidadãos devem gozar do princípio da (igual) participação, ao tratar da justiça política e da constituição. A Constituição deve ser fruto de um processo justo, caracterizado pelo igual direito de se manifestar no processo constitucional, em uma assembleia representativa composta por partidos políticos que enunciam uma concepção de bem público.

Sendo o Estado a autoridade máxima sobre um território, ele afeta as expectativas das pessoas. O processo constitucional conduzido pelo Estado, assim, deve preservar a representação igual, que se mostrava presente na “posição original”, isto é, aquela na qual estão naturalmente interiorizados nos indivíduos os princípios da justiça.

O autor elaborou a teoria da "justiça como equidade”, sedimentada sobre os princípios da justiça social, sendo um deles a determinação de que “[...] cada pessoa deve ter um direito igual ao mais abrangente sistema de liberdades básicas iguais que seja compatível com um sistema semelhante de liberdade para as outras.” ${ }^{500}$ Esse

498 Dahl reconhece o valor desse princípio, em sua estrutura poliárquica, e determina que a democracia deve proporcionar oportunidades para: participação efetiva, igualdade de voto, aquisição de entendimento esclarecido, exercer o controle definitivo de planejamento e inclusão de adultos. DAHL, R. Sobre a democracia. Brasília: UnB, 2001, p. 50. Nas poliarquias, as crises e questionamentos são suplantados pela cooperação política e pela definição das prioridades, desde que mantida a maximização da igualdade como meta suprema.

499 A teoria rawlsiana de justiça cuida do justo e do injusto a partir da ideia de "justiça como equidade", pela qual a equidade reside na posição igualitária estabelecida no estado inicial do contrato social e que é objeto do consenso original. Os indivíduos escolhem os princípios da justiça sob um "véu de ignorância", sem tomar conhecimento de informações particulares sobre sua situação na sociedade. RAWLS, John. Uma teoria da justiça. São Paulo: Martins Fontes, 2000.

500 RAWLS, J. Op. cit., p. 5. O segundo princípio da justiça social estabelece que as desigualdades econômicas e sociais devem ser ordenadas de modo a serem consideradas vantajosas para todos, dentro de certos parâmetros e associadas a posições e cargos acessíveis a todos. 
princípio forma a estrutura básica da sociedade e determina a distribuição de direitos e deveres. Seguindo essa orientação, as liberdades políticas devem ser distribuídas de forma equânime para todos.

Por isso, afirma-se que a justiça como equidade é compatível com o regime democrático representativo. A busca por resultados mais justos representa a própria busca pelo aperfeiçoamento do método democrático, devendo ser criadas “[...] condições mais equitativas para que os cidadãos influenciem as decisões políticas e constituam preferências informadas sobre as questões mais importantes de política pública.”501

Essas condições são facilitadas pelo princípio da (igual) participação, o qual favorece a integração de todos os cidadãos ao processo político democrático, ao estimular a adesão a partidos políticos e a candidatura a cargos eletivos, reiterando a força da igualdade de voto.

A igualdade de voto está diretamente ligada, ademais, à liberdade de expressão e de associação. Para que a escolha seja feita, é necessário tomar conhecimento das opções e propostas trazidas por grupos livremente criados.

A autenticidade eleitoral precisa ser atestada por um sistema de poderes capaz de averiguar a legalidade das eleições, as condições de elegibilidade dos candidatos e a verificação do número de votos recebidos, ou seja, demanda a verificação da lisura do processo eleitoral em sua integralidade. No Brasil, essa função é exercida pela Justiça Eleitoral, cuja criação, estrutura e competências já foram observadas em capítulo próprio. Coneglian exprime a relevância dessa instituição para a democracia, ao comparar a Justiça Eleitoral "[à] ponta de lança da democracia, o organismo em que o político, o eleitor, a Nação toda têm colocado sua confiança, para que as eleições sejam limpas, e os seus resultados sejam aqueles que o povo escolheu.”502

501 VITA, Álvaro de. Democracia deliberativa ou igualdade de oportunidades políticas? Novos Estudos Cebrap, São Paulo, n. 66, jul. p. 117, 2003.

502 CONEGLIAN, Olivar. Propaganda eleitoral. 3. ed. Curitiba: Juruá, 1998, p. 55. 
As instituições exercem importante função na organização política da sociedade. Os arranjos institucionais reduzem incertezas e estabelecem premissas para a tomada de decisão, além de representarem um terreno estável nas escolhas coletivas. Seu valor, portanto, deve ser sempre relembrado.

O voto, além de ser igual, livre e secreto, é igualmente personalíssimo. O ato de votar é restrito ao eleitor, que se apresenta para a votação sem poder contar com a intermediação de interposta pessoa.

O texto constitucional é expresso ao declarar a periodicidade do voto como cláusula pétrea, o que traz consigo o mandamento democrático a exigir renovação dos cargos eletivos e a temporalidade dos mandatos.

A eleição do modelo proporcional para a eleição na Câmara dos Deputados ${ }^{503}$ não afeta o princípio da imediaticidade do voto, o qual impõe ao eleitor votar diretamente em um determinado político ou partido, sem que haja instância ou colégio eleitoral a intermediar a escolha feita diretamente pelos eleitores. ${ }^{504}$

Por fim, o voto no Brasil é obrigatório, ${ }^{505}$ tradição que teve início com o Código Eleitoral de 1932.

O debate em torno da obrigatoriedade do voto é um dos mais recorrentes do Congresso Nacional, e sempre enfatizado pela opinião pública, em anos eleitorais. A razão estaria na discussão de propostas tendentes a reverter o crescente absenteísmo nas eleições e o considerável aumento dos votos brancos e nulos. ${ }^{506}$

Discorre Sampaio que a natureza jurídica do voto é um dever:

503 BRASIL. CF/88, Art. 45, caput: A Câmara dos Deputados compõe-se de representantes do povo, eleitos pelo sistema proporcional, em cada Estado, em cada Território e no Distrito Federal.

504 MENDES, Gilmar Ferreira; COELHO, Inocêncio M.; BRANCO, Paulo Gustavo G. Op. cit., p. 859861.

505 Com a facultatividade aos analfabetos, aos maiores de 70 anos e maiores de 16 e menores de 18 anos, como estabelecido na CF, art. 14, II, a,b,c.

506 Nas últimas eleições de 2012, o número de votos brancos e nulos, que não são considerados na definição dos resultados, foi de 9,8\%, o maior computado no Brasil desde o $2^{\circ}$ turno de 1996. Disponível em: <http://www1.folha.uol.com.br/poder/1177091-numero-de-votos-brancos-e-nulos-eo-maior-do-brasil-no-2-turno-desde-1996.shtml>. Acesso em: 7 jan. 2013. 
[...] conclui-se que o voto tem, primordialmente, o caráter de uma função pública. Como componente do órgão eleitoral, o eleitor concorre para compor outros órgãos do Estado também criados pela constituição. Em geral, porém, as constituições têm deixado o exercício da função de votar a critério do eleitor, não estabelecendo sanções para os que se omitem. Nessa hipótese, as normas jurídicas sobre o voto pertenceriam à categoria das normas imperfeitas, o que redundaria em fazer do sufrágio simples dever cívico ou moral. Somente quando se torna obrigatório, o voto assumiria verdadeiro caráter de dever jurídico. ${ }^{507}$

Para os defensores do voto facultativo, o ato de votar deve ser entendido como um direito subjetivo do cidadão, relacionado ao desejo ou recusa em exercer seu direito de liberdade de expressão e manifestação. Alegam, ademais, que países desenvolvidos e com tradição democrática adotam o voto facultativo, e que esse modelo melhoraria a qualidade do pleito, pois votariam apenas os eleitores mais conscientes e motivados.

É verdade que a participação política, a qual dá legitimidade para a democracia representativa, não deveria ser imposta. Por outro ado, deve ser lembrado o comportamento do eleitor brasileiro, que possui a tradição do voto ligada profundamente às características do país. No Brasil, existem eleições desde o Brasil Colônia, realizada no dia 23 de janeiro de 1532, para eleger o Conselho da Vila de São Vicente - SP, primeira vila aqui fundada pelos portugueses. ${ }^{508}$ De fato, não foram eleições gerais e pode-se até ponderar que na colônia não havia nenhum traço do modelo democrático que surge no século XIX. Há de se reconhecer, contudo, a influência dessa prática na história brasileira e sobre o comportamento do eleitor, que nunca apresentou uma resistência organizada contra essa obrigatoriedade, assimilando-a como um ganho de participação no processo eleitoral.

A obrigatoriedade do voto, em acréscimo, é relativizada em função das sanções impostas:

A verdade é que a justificativa - quanto à ausência na votação importa num procedimento extremamente simples e as multas são irrisórias - isto quando não há anistia quanto às sanções eleitorais - o

507 SAMPAIO, Nelson de Souza. Eleições e sistemas eleitorais. Revista de Jurisprudência, Rio de Janeiro, $1^{\circ}$ trimestre, p. 66, 1981.

508 FERREIRA, Manoel Rodrigues. A evolução do sistema eleitoral brasileiro. Brasília: Senado Federal, 2001, p. 355. 
que, não prática do cotidiano, conforma o nosso voto como facultativo. ${ }^{509}$

O voto deve ser visto como um exercício de um direito individual, mas também como um dever do cidadão em fazer parte das decisões da coletividade a que pertence. ${ }^{510}$ A omissão do eleitor apenas enfraquece a democracia, devendo ser incentivada a educação política que leva o debate eleitoral para o dia a dia dos cidadãos, e estimulada a participação dos mais jovens, que serão os eleitores do futuro.

A democracia representativa, no entanto, não significa democracia eleitoral, nem se restringe ao ato de votar, ideia que desenvolve com primazia Urbinati. ${ }^{511}$ Como ensina a autora, “[...] as eleições ‘engendram’ a representação, mas não ‘engendram’ os representantes.” 512 A eleição é uma das várias dimensões da representação. A dificuldade que a eleição trouxe ao entendimento deste último conceito foi o de que, ao se tornar indispensável para o processo de legitimação política, ela estabeleceu um elo indissolúvel entre Estado e sociedade civil, porém, não é capaz de atender a todas as demandas dessa relação, nem soluciona todos os dilemas que dela advêm. O momento eleitoral é vital para gizar os limites da responsabilidade política, mas, para que o processo representativo se harmonize com a democratização, exige-se a constante reavaliação do soberano ${ }^{513}$ sobre a correspondência entre as suas ideias e o seu voto, ${ }^{514}$ além da sua reiterada atuação na definição dos projetos a construir a sociedade. A representação deve ser, por conseguinte, concebida como um avanço da prática política,

509 CAGGIANO, Monica H. S. O cidadão-eleitor, jogador com veto no processo eleitoral democrático: aspectos polêmicos e peculiares do cenário brasileiro. Eleições gerais 2010. In: INSTITUTO VICTOR NUNES LEAL (Org.). A contemporaneidade do pensamento de Victor Nunes Leal. São Paulo: Saraiva, 2013, p. 269.

510 “A igualdade do sufrágio é um direito assente no direito moderno. [...] O sufrágio é ao mesmo tempo um direito e uma função.” AMADO, Gilberto. Op. cit., p. 65.

511 URBINATI, Nadia. Op. cit.

512 URBINATI, Nadia. Op. cit., p. 193.

513 “Um representante político é único não porque substitui o soberano na aprovação das leis, mas precisamente porque ele não é um substituto para o soberano ausente (a parte que constitui o todo), uma vez que ele precisa ser constantemente recriado e estar dinamicamente em harmonia com a sociedade para aprovar leis legítimas.” URBINATI, Nadia, Op. cit., p. 194.

514 Conforme Urbinati, essa identificação com uma ideologia partidária dá unidade e continuidade às decisões políticas, o que é muito importante, face aos diferentes momentos e transformações pelos quais passa o Estado e a sociedade. O sentimento da mantença ideológica fortalece as instituições, o que não acontece em uma democracia direta, em que cada decisão é tomada autonomamente. URBINATI, Nadia. Op. cit. 
que provoca “[...] a disseminação da presença do soberano e sua transformação em uma tarefa contínua e regulada de contestação e reconstrução da legitimidade”. 515

Manin possui obra clássica sobre o governo representativo, entendido pelo autor como um sistema complexo composto por vários elementos. Na origem desse governo, prevalecia o princípio da distinção. ${ }^{516}$ Os monarcas representavam os súditos, todavia, nesse período histórico, eram os súditos que se submetiam aos monarcas, acatando suas ordens em todo o território da nação. Esse sentido passa por uma completa alteração. O crescimento das tensões sociais levam os súditos para as ruas, e seus protestos ecoam no parlamento. As revoluções liberais invertem o sentido da representação, que, se antes era descendente, passa a ser ascendente, com o povo a exigir expansão do sufrágio e o atendimento de suas demandas, no parlamento. Desde esse tempo, ocorre a democratização da representação.

O autor continua a análise ressaltando que as eleições formam a engrenagem central desse mecanismo representativo, mas não é seu elemento único. A representação comporta outras partes, incluindo provisões para a discussão pública e a liberdade de opinião pública, ${ }^{517}$ que possibilita a exteriorização da opinião, ${ }^{518}$ chamando a atenção daqueles que governam.

O governo representativo moderno é estruturado sem a presença de partidos políticos organizados. ${ }^{519}$ É a partir da segunda metade do século XIX que os partidos políticos despontam como ferramenta essencial na expressão da manifestação de vontade do eleitorado. Uma nova transformação das relações de representação acontece

515 URBINATI, Nadia. Op. cit., p. 193.

516 “.... el tratamento desigual de los votantes, la distinción de los candidatos requerida por una situación selectiva, la ventaja cognoscitiva que otorga una situación de prominencia y el coste de diseminar información. MANIN, Bernard. Los principios del gobierno representativo. Trad. Fernando Vallespin. Madrid: Alianza, 1998. p. 165.

517 MANIN, Bernard. Op. cit. Capítulo V.

518 Como ensina Manin, a primeira emenda da Constituição norte-americana, que prevê o direito de reunião pacífica e o direito de petição ao governo, sempre fez parte da gênese do sistema representativo.

519 Os fundadores do governo representativo acreditavam que a divisão entre partidos ou "facções" era uma ameaça ao sistema que pretendiam implementar. Para Madison, a facção representava a maioria unida, agindo sob um impulso comum em sentido oposto aos direitos ou interesses de outros cidadãos ou de outra coletividade. HAMILTON, A; MADISON, J.; JAY, J. Os Artigos Federalistas. Rio de Janeiro: Nova Fronteira, 1993. 
com o advento dos partidos de massa, aqueles partidos organizados que aproximam representante do representado, funcionando como canais de mensagem dos anseios do eleitorado. Nesse modelo representativo democrático, os partidos são unidades fundamentais da vida política, porque eles unem eleitores dispersos e distantes de um canal de comunicação, agrupando-os sob a sua coerência ideológica e obtendo deles fidelidade política.

No final do século XIX, Manin observa uma nova metamorfose ${ }^{520}$ da representação. Surgem os sinais de sua crise, já identificada por Ostrogorski. ${ }^{521}$ A democracia de partido cede espaço para a democracia de público, que ainda coexiste com os partidos, mas agora eles não são mais o elemento agregador dos cidadãos: os partidos deixam de ser decisivos e têm que buscar o apoio dos eleitores, os quais passam, por sua vez, a dar importância à figura individual do candidato. Os partidos perdem sua identidade e ideologia clara e definida, alterando a composição de seu grupo a cada eleição. Essa falta de identidade acarreta o distanciamento do público.

Urbinatti enfatiza que o declínio da democracia de partidos leva ao chamado plebiscito da audience, caracterizado pelo

[...] aglomerado indistinto de indivíduos que compõem o público, um ator não coletivo que vive no espaço privado da domesticidade e, quando é agente sondado de opinião, atua como receptor ou espectador de um espetáculo encenado por técnicos da comunicação midiática e recitado por personagens políticos. ${ }^{522}$

Os partidos, como sempre, coexistem com as demais instituições de poder e, a despeito de terem perdido legitimidade junto aos cidadãos, eles continuam sendo imprescindíveis à estrutura da democracia representativa. Só que, nesse estágio, eles não são mais um "partido-organização”, como eram durante a democracia de partidos, mas sim “partidos-esponja”, os quais absorvem interesses e opiniões obtidos durante as

520 MANIN, B. As metamorfoses do governo representativo. Revista Brasileira de Ciências Sociais, São Paulo, n. 29, out. 1995, p. 5-34.

521 OSTROGORSKI, M. Op. cit.

522 URBINATI, Nadia. Da democracia dos partidos ao plebiscito da audience. Lua Nova, São Paulo, vol. 03, n. 05, p. 86, jan./jun, 2013. 
pesquisas e sondagens, interpretando os "humores sociais" e aproveitando-se deles para vencer as eleições. ${ }^{523}$

O que Manin chama de democracia de público é entendido por Urbinati como o plebiscito da audience, controlado pelas especialistas da mídia, os quais provocam a espetacularização das eleições e transformam “[...] o processo de formação das opiniões em [...] um tribunal da transparência e da revelação que condiz mais com a demagogia que com a deliberação pensada." ${ }^{524}$

De qualquer forma, a democracia só tem sido possível na configuração representativa. As críticas ao modelo, todavia, avolumam-se, sempre com o fito de explicar o hiato entre sociedade e Estado, ou, ainda, entre a palavra e a ação dos partidos e dos políticos. No Brasil, tem prevalecido uma representação política composta por um eleitorado anônimo ao qual nada se deve, a não ser promessas eleitorais. A crise de representatividade ecoa no meio acadêmico, político e midiático, que levantam suas causas e propõem modelos para sua superação. ${ }^{525}$

Nos projetos de consolidação democrática que se esboçam, cidadãos e Estado possuem uma relação próxima, os governantes representam os cidadãos face ao Estado,

523 URBINATI, Nadia. Idem, p. 89.

524 URBINATI, Nadia. Idem, p. 93. Pensamos que essa compreensão do momento da democracia representativa desenvolvida por Urbinati coaduna-se com a legitimidade das cortes constitucionais, como concebida por Rosanvallon. Para o historiador francês, a ideia da lei da maioria foi muito bem aceita, sem grandes debates ou discussões. O poder que emana do resultado estabelecido pelas urnas remete à ideia de vontade geral, ou à ideia de um povo que representa a maioria, ou o conjunto da sociedade. O parlamento seria o espaço de encontro dessas vozes, só que ele se corrompe em negociações escusas para atender a interesses particulares. Emergem, assim, novas estruturas legitimadas a agir ou falar em nome da sociedade. A vida democrática ultrapassa a esfera eleitoralrepresentativa e ganha novas dimensões em instituições como as Cortes Constitucionais, cujo trabalho se direciona a preencher as lacunas democráticas. Como explica o autor, a corte constitucional deixa de ser o legislador negativo proposto por Hans Kelsen e assume o poder de dar voz ao cidadão, assumindo a função de representação social e política. Ou, como salienta Rosavallon, usando a expressão de Garapon, o Judiciário possui representatividade por ser o "guardião das promessas” feitas pela Constituição. Mas, se o Judiciário fala pelos cidadãos, a estes basta apenas ouvi-lo, basta permanecer em uma posição passiva, tal como acontece quando estão diante dos comandos dados pelos meios de comunicação no plebiscito da audience. Cf. ROSAVALLON, Pierre. La legitimité democratique: impartialité, reflexivité, proximité. Paris: Éditions du Seuil, 2008; GARAPON, Antoine. Op. cit.

525 Como explica Costa, um dos modelos propostos seria o da democracia participativa, “[...] uma reação às promessas não mantidas da democracia representativa; uma tentativa capaz de restituir aos sujeitos uma iniciativa política e uma influência no processo de decisão que parecem hoje comprometidos pelo formalismo do sistema representativo e pelo elitismo dos partidos”. COSTA, Pietro. Poucos, todos, muitos: lições de história da democracia. Trad. Luiz Fritolo. Curitiba: UFPR, 2012, p. 300. Ou, ainda, a alternativa lançada pela democracia deliberativa e as lições do mestre Habermas. 
o diálogo é livre de pressões e há uma pluralidade de vozes que convergem para o bem social. Isso indica que o governo representativo sempre exibiu uma faceta não eleitoral.

A sociedade plural, entretanto, não consegue se harmonizar, e suas contradições penetram a esfera pública por todos os lados. Paradoxalmente, o impasse tem reforçado a necessidade de se levar adiante a reflexão sobre a democracia representativa, consolidando as instituições já existentes e fortalecendo a accountability e a responsibility, ${ }^{526}$ as quais ganham primazia sobre a representação, já que são capazes de formar, manter e aprimorar o pacto criado entre partidos, representante e representados, sempre na busca por um modelo mais democrático.

Conforme defendido em outro momento, ${ }^{527}$ a democracia representativa pode ser reformulada pela Internet, capaz de ampliar os espaços de participação e de estimular a capacidade de intervenção na esfera pública, mobilizando, pressionando, persuadindo os atores políticos. Isso já acontece - como tentaremos demonstrar, ao verificar o uso das mídias sociais em momentos eleitorais brasileiros -, porém, não em sua totalidade, não com a plena consciência desse processo, mas se pode afirmar que se encontra em andamento essa democracia eletrônica, um novo pacto democrático, com condições de dar protagonismo à sociedade civil. Afinal, o que a democracia exige da representação é a manutenção da ligação entre as decisões políticas e as preferências dos representados, por meio de mecanismos institucionais que promovam a integração social. A sociedade civil precisa participar do debate sobre o processo de democratização das instituições representativas, e pode fazê-lo a partir das novas mídias disponibilizadas pela Internet, que se impõe para o fortalecimento da cidadania.

526 “.... le peuple ne peut pas se conduire seul, surtout dans les grands Etats et spécialement dans les Etats contemporains. Dans ces conditions, les lois fondamentales prévoient que le pouvoir appartient au peuple qui l'exerce par ses organes représentatifs ou/et par référendum. Si les choses vont bien (mais où vont-elles bien?) le problème de la responsabilité ne se pose pas. Mais si, au contraire, les choses vont mal [...] il se pose le problème du controle et de la responsabilité”. VRABIE, Genoveva. Etudes de droit constitutionnel. Iași: Institutul European, 2003, p. 48.

527 Durante o Mestrado defendido na Universidade Presbiteriana Mackenzie, elaboraram-se com mais detalhes as questões relacionadas à crise de representatividade e o processo de desenvolvimento da democracia eletrônica, comparando-a com outros modelos democráticos. 
Ao longo de tantos anos de experiências e crises, as instituições representativas mostram sua resistência, comprovando sua alta capacidade adaptativa. O novo desafio é trazido pela Internet. ${ }^{528}$

A crise da representatividade, contudo, continua a espreitar a democracia. Os problemas são conhecidos.

A pluralidade de ideias, de princípios, de interesses é um desideratum da democracia, mas dificilmente haverá 32 partidos políticos - como há hoje no Brasil com 32 ideologias diferentes, a representar correntes políticas da sociedade. Isso não contribui para a estabilidade do sistema político. O sistema legal precisa de eficiência e simplicidade, o que é muito difícil de ser alcançado com essa estrutura.

O problema dos partidos “nanicos”, aqueles pequenos e sem representatividade, está longe de ser resolvido. A origem está na decisão do STF, que derrubou a "cláusula de barreira”, ${ }^{529}$ regra contida na Lei dos Partidos Políticos e que restringia a atuação das pequenas legendas. Segunda essa lei, era previsto que o partido seria obrigado a ter um mínimo de 5\% de votos na Câmara, distribuído por um mínimo de 9 Estados, ou perderia acesso a 99\% dos recursos do Fundo Partidário, além de ter seu tempo de propaganda reduzido a 2 minutos na rádio e na televisão, por semestre. Era uma regra que tendia a estimular a fusão de partidos pequenos. ${ }^{530}$ Todavia, o STF considerou-a inconstitucional, por infringir o princípio do pluralismo.

528 Em 1996, Caggiano já vislumbrara a relação Internet e processo eleitoral, ao afirmar que "[o] processo eletrônico constitui, não há dúvida, um avanço; uma conformização aos tempos contemporâneos dominados pela informática, da qual, parece-me, não há como se esconder. Evidente, contudo, que a máquina não poderá expressar com a mesma fidelidade a vontade do eleitor, será incapaz de qualquer esforço interpretativo da opção eleitoral.” CAGGIANO, Monica H. S. Eleições municipais de 1996, com ênfase para o quadro de São Paulo. Revista da Faculdade de Direito Universidade de São Paulo, São Paulo, ano 1, n. 1, v. 91, p. 361, 1996.

529 Termo aplicado à exigência de um número mínimo de votos para que um partido ou coligação mantenha sua existência ou representatividade no parlamento, presente em vários países. No Brasil, ela foi aprovada em 1995, e teria sido aplicada nas eleições de 2006, não fosse a declaração de inconstitucionalidade do STF (ADI 1351/DF e ADI 1354/DF, de relatoria do Min. Marco Aurélio). Se tivesse sido adotada, só sete dos vinte e nove partidos registrados no TSE teriam conseguido atingir os percentuais estipulados pela lei.

530 Em 2010, os partidos nanicos ocuparam 27\% do horário eleitoral - um horário subsidiado pelo Estado, através de abatimentos em impostos das emissoras de rádio e televisão - e custaram em torno de 35 milhões aos cofres públicos. Disponível em: $<$ http://www.estadao.com.br/noticias/nacional,partidos-nanicos-tem-27-do-horarioeleitoral,549540,0.htm>. Acesso em: 10 mai. 2010. 
O princípio do pluralismo político levou ao multipartidarismo, sempre envolvido em questões degradantes. Logo depois da formação dos mais novos partidos políticos - Pros (Partido Republicano da Ordem Social) e Solidariedade - as manchetes dos jornais destacavam a promessa de verba para atrair deputados. Apesar de a Justiça Eleitoral ter previsto a fidelidade partidária, ${ }^{531}$ que determina perda de mandato a quem muda de sigla, não há punição na migração a novos partidos, e os congressistas se beneficiam dessa brecha legal para escapar das cassações. Por isso, era possível presenciar a transformação do Congresso em um balcão de negócios após o surgimento de mais dois novos partidos. A cada congressista era oferecido de $\mathrm{R} \$ 3,00$ a $\mathrm{R} \$ 3,80$ por voto recebido para se filiar aos novos partidos. ${ }^{532}$ A troca de partidos envolveu 47 congressistas, apenas no primeiro dia. De acordo com a reportagem da Folha de $S$. Paulo, pelo menos 46 deputados - ou 8,9\% da Casa - e 1 senador negociavam entrar no Solidariedade ou Pros. ${ }^{533}$

Por outro lado, a Rede Sustentabilidade teve seu registro negado.

O pluralismo político é um dos fundamentos do Estado brasileiro, sendo esta a razão que fundamenta a livre criação de partidos, prevista no art. 17 da CF. Evidente que há uma série de critérios para a efetivação do registro de um partido, como a demonstração de seu caráter nacional e número mínimo de assinaturas fixado pela lei.

No decorrer do processo de registro, a Rede informou que 867 mil assinaturas de apoiadores foram colhidas em todo o país. No entanto, das 640 mil assinaturas que foram entregues à Justiça Eleitoral, 304 mil foram certificadas pelos cartórios eleitorais e cerca de 220 mil ainda precisam ser analisadas ${ }^{534}$. Duas questões polêmicas foram levantadas: a primeira referia-se ao fato de muitos cartórios se encontrarem em mora. O

531 Desde que a Justiça determinou que o mandato é do partido, e que desfiliações sem justa causa devem ser punidas com perda de mandato, o único deputado a receber uma sanção foi Robson Rodovalho, que, em 2009, trocou o DEM pelo PP.

532 Disponível em: <http://congressoemfoco.uol.com.br/noticias/nos-jornais-novos-partidos-prometemverba-para-atrair-deputados/>. Acesso em: 22 set. 2013.

533 Disponível em: <http://www1.folha.uol.com.br/poder/2013/09/1347630-troca-de-partidos-envolve47-congressistas-no-1-dia.shtml>. Acesso em: 29 set. 2013.

534 Disponível em: <http://agenciabrasil.ebc.com.br/noticia/2013-09-23/tse-determina-recontagem-deassinaturas-de-apoiadores-do-rede-sustentabilidade>. Acesso em: 30 set. 2013. 
cartório possui 15 dias para validar ou não a assinatura, de acordo com a lei. Se o poder público não consegue cumpri-lo, o ônus não deveria recair sobre o requerente.

Além disso, calcula-se que 95 mil assinaturas foram desconsideradas sem o menor tipo de motivação. Ora, em sendo o cartório uma repartição pública, ele deve informações aos cidadãos, e precisaria ter explicado o porquê do não reconhecimento das assinaturas, o que não aconteceu.

Diante disso, o TSE negou o pedido de registro, com base no não cumprimento dos requisitos legais.

A exigência de um número mínimo de assinaturas tem um fundamento lógico: garantir que os partidos, que farão jus a verbas públicas do fundo partidário e tempo de rádio e televisão, tenham um mínimo de representatividade. O que não seria muito difícil para uma ex-candidata que obteve votação expressiva na última eleição e um partido com 640 mil assinaturas encaminhadas aos cartórios do país.

Ao invés da adoção desse trâmite burocrático, a representatividade deveria ser apontada pelo voto. O ideal seria que o fundo partidário nem existisse, e que os partidos se sustentassem com doações de seus apoiadores. Como é praticamente impossível a eliminação desse fundo, dever-se-ia impor uma cláusula de barreira a ele, que estipulasse permissão para uso da verba com base no número de votos recebidos na eleição anterior. A criação de partidos continuaria livre. Apenas o controle do acesso ao fundo seria feito pelas urnas, o que parece uma alternativa mais democrática. ${ }^{535}$

É necessária uma democratização urgente dos partidos, que envolva sua democracia interna, com a estipulação de regras de tempo de permanência dos líderes e com a abertura de discussão das decisões para o eleitorado de base. O esvaziamento da política com a priorização da gestão é uma falha que tem causado danos graves à democracia.

535 Recentemente, em outubro de 2013, o governo conseguiu aprovar a Lei $n^{\circ} 12.875 / 2013$, que impede a transferência de recursos do Fundo Partidário e de tempo de propaganda eleitoral gratuita de um partido a outro recém-criado, quando ocorre a migração de um parlamentar. De acordo com a lei, os deputados só irão carregar consigo os benefícios do Fundo Partidário e tempo de propaganda quando houver fusão dos partidos. 
Merece ênfase a pesquisa conduzida pela FGV/SP, sob a coordenação da Professora Luciana Gross Cunha, intitulada “Índice de Confiança na Justiça Brasileira” (ICJBrasil), ${ }^{536}$ um levantamento estatístico realizado em sete Estados brasileiros, a partir de amostra representativa da população, cujo foco é averiguar a legitimidade do Poder Judiciário e a confiança do cidadão nessa instituição.

A pesquisa explora a percepção dos cidadãos sobre a competência e a honestidade no Judiciário, os motivos que levam os entrevistados a buscar essa instituição e o resultado sobre a confiança dos entrevistados, em várias instituições brasileiras. Essa investigação verifica que a confiança nas Forças Armadas é de 71\%; na Igreja, 53\%; o Ministério Público fica com 53\% da credibilidade e a imprensa escrita, com $45 \%$. A confiança no governo federal é de $41 \%$, maior do que a confiança na Justiça, que fica com 37\%, seguida da Polícia, com 34\%, emissoras de TV, com 31\%; o Congresso Nacional possui $20 \%$ de confiança e, por último na lista, aparecem os partidos políticos, com apenas 7\%.

Interessante notar que há uma desvinculação entre governo federal, Congresso e partidos. A diferença de confiança entre esses dois últimos é significativa, como se os partidos não fizessem parte do Congresso. E a confiança no governo federal talvez seja uma explicação para o fato de a Ação Penal 470, conhecida como “mensalão", ter condenado vários membros do partido do governo, sem que isso afetasse candidaturas petistas nas últimas eleições, quando o Partido dos Trabalhadores saiu maior do que entrou. $^{537}$

O aperfeiçoamento do sistema político representativo requer a constante evolução das regras que o definem. O número de partidos, os requisitos para sua participação, os instrumentos de exercício da fidelidade partidária, o sistema eleitoral,

536 O ICJBrasil é publicado trimestralmente pela DIREITO GV. Disponível em: <http://bibliotecadigital.fgv.br/dspace/bitstream/handle/10438/11221/Relat\%C3\%B3rio\%20ICJBrasi 1\%20-\%20Ano\%204.pdf?sequence=1>. Acesso em: 2 dez. 2013.

537 Ao se verificar o site do TSE e se comparar o número de votos de cada partido, conclui-se que o PT conquistou 4,3\% mais sufrágios do que em 2008. Em número total de votos, saltou de 16,5 milhões para 17,2 milhões, mesmo com a ação do mensalão em curso, mas já com a definição daqueles que iriam ser presos. Não é o foco da presente tese investigar os motivos desse fato, mas cabe indagar se há uma desvinculação entre partidos e candidatos, o que condiz com o fato de o brasileiro votar em candidato, e não em partido, ou se a falta de opção ou o desencanto com a política faz com que todos os candidatos sejam vistos como ruins, mas, como o voto é obrigatório, tenta-se votar naquele considerado um pouco melhor. Uma questão que merece longo debate. 
todas essas questões precisam ser revistas. Nada trará mais benefícios à credibilidade da classe política e dos partidos do que criar mecanismos que os tornem mais responsáveis perante as cobranças do eleitorado. Os partidos precisam ser transformados e remodelados, para que evoluam e aperfeiçoem a democracia.

Sendo a democracia um método de gestão de conflitos, é preciso acreditar que a crise provocará uma renovação do sistema.

Beçak resume com propriedade esse cenário, apontando a necessidade do reexame do uso dos instrumentos democráticos, posto que

[...] a crítica à realização da democracia em sua forma tradicional, i.e., pelos partidos políticos, de há muito formulado, permanece nos dias de hoje.

Assim, o mero exercício do voto não basta. É só com a participação efetiva da população no processo que se pode fazer com que a democracia permeie por todos os setores da sociedade. ${ }^{538}$

Nas democracias de massa contemporâneas, parece impossível aludir à melhoria dos sistemas políticos, sem que se tenha presente a importância do papel dos meios de comunicação e, especificamente, a Internet. Castells ${ }^{539}$ afirma, com propriedade, que o espaço político foi invadido pelos meios de comunicação, por seus fluxos e imagens. Portanto, eles devem assumir um compromisso social, devendo promover a análise dos fatos e auxiliar a cidadania a formar juízo sobre os assuntos em pauta.

É imperativo, ademais, alargar o espaço público para incluir progressivamente os cidadãos. A Internet amplia o escopo da representação política, ao apresentar novos espaços de mediação e estimular a participação, expandindo os horizontes democráticos e acentuando o papel do cidadão na formação de uma sociedade com mais igualdade e liberdade.

538 BEÇAK, Rubens. Instrumentos de democracia participativa. Revista de Ciências Jurídicas, Maringá v. 6, n. 2, $\quad$ p. $153, \quad 2008 . \quad$ Disponível em: <http://www.periodicos.uem.br/ojs/index.php/RevCiencJurid/article/view/10942>. Acesso em: 2 set. 2012.

539 CASTELLS, Manuel. A era da informação: economia, sociedade e cultura. Vol. II - O poder da identidade. Trad. Klauss Brandini Gerhardt. São Paulo: Paz e Terra, 2000. 
O espaço político deixado em aberto pelos partidos e pelas instituições em descrédito pode ser ocupado pela Internet, dada sua flexibilidade, informalidade e capacidade de mobilização. Ela oferece uma alternativa na busca da implementação de interesses coletivos. O desencanto popular não se refere à democracia em si, mas a um tipo específico de sua configuração. Ao ampliar o conceito restrito de participação tradicionalmente vinculado à representação (participação no sufrágio), a Internet age como catalisador da expansão dos fóruns de realização política.

Gomes, Maia e Marques ${ }^{540}$ citam exemplos de iniciativas com alto teor democrático, que têm sido muito bem recebidas pelos cidadãos e que adotam tecnologia de fácil acesso, com destaque para “[...] o projeto de petições online do parlamento britânico, a cidade digital de Hoogeveen, o Minnesota e-democracia, o projeto Edemocracia da Câmara dos Deputados, Transparência Brasil e Contas Abertas.”

O projeto e-democracia da Câmara dos Deputados ${ }^{541}$ objetiva estimular o debate sobre temas importantes para o país diretamente com a sociedade. Divide-os de duas formas: uma parte do site, chamada de "Comunidade Legislativa”, propõe temas de discussão, geralmente relacionados a projetos de lei em andamento. A segunda parte do site é o "Espaço Livre”, no qual o próprio cidadão pode propor um tema para discussão. Para participar, basta fazer um simples cadastro. Assim, não só o cidadão pode entender como se dá o andamento de um projeto de lei e dar sugestões para seu aprimoramento e adequação aos interesses sociais, como os próprios parlamentares podem usar as sugestões apresentadas, ou verificar os debates que são levantados pelos cidadãos, podendo dar concretude a esses apelos. Foi fundamental na elaboração do Marco Civil da Internet.

O Transparência Brasil, ${ }^{542}$ por sua vez, é uma organização independente e autônoma, criada em abril de 2000, cujo comprometimento é com o combate à corrupção. Para tanto, seus idealizadores realizam levantamentos empíricos sobre a incidência da corrupção em várias esferas do governo e setor privado. Desenvolvem,

\footnotetext{
540 GOMES, Wilson; MAIA, Rousiley C. M.; MARQUES, F.P.J.A. Internet e participação política no Brasil. Porto Alegre: Sulina, 2011, p. 28.

541 Disponível em: <http://edemocracia.camara.gov.br>. Acesso em: 12 out. 2013.

542 Disponível em: <http://www.transparencia.org.br/>. Acesso em: 12 out. 2013.
} 
também, instrumentos de Internet que facilitam o monitoramento da corrupção no país. Assim, eles traçam um perfil da vida pública de parlamentares, verificando o registro de aumento de patrimônio, por exemplo, ou fornecendo dados sobre o financiamento eleitoral. Possuem parcerias com entes públicos para combater a corrupção e valorizam a participação do cidadão em todas essas ações, que são abertas para acompanhamento e apoio.

Já o Contas Abertas ${ }^{543}$ é uma entidade da sociedade civil, sem fins lucrativos, formada por pessoas físicas, jurídicas ou qualquer interessado em contribuir para a melhoria da transparência e da legalidade do dispêndio público. Além disso, estimula o cidadão na elaboração e acompanhamento dos orçamentos públicos.

Portanto, existem várias iniciativas digitais em andamento, ${ }^{544}$ no Brasil e no mundo, todas buscando a transparência dos atos públicos, o envolvimento dos cidadãos em suas comunidades e a consequente melhoria da democracia, que pode ser modificada pelas novas tecnologias de várias formas. Administrativamente, a Internet contribui para a transparência na gestão administrativa e promove a eficiência na prestação dos serviços públicos, melhorando seu relacionamento com o cidadão e fortalecendo a cidadania ativa. A maior participação dos cidadãos no processo decisório via Internet revitaliza a democracia, ao resgatar o valor das instituições e aproximá-las dos cidadãos. A criação de comunidades virtuais, como mostradas acima, outrossim, desenvolvem uma representação simbólica com participação no processo político. São potencialidades transformadoras que abrem a oportunidade de reconfiguração dos mecanismos de participação democrática.

O termo participação civil, aliás, foi reiterado várias vezes ao longo do texto. Vale pontuar que participação civil não é um fim, ela não é normativamente justificada simplesmente pela sua existência. Ela se justifica em função da sua importância e valor para a democracia, na medida em que fortalece a esfera civil e as minorias políticas. Para a democracia,

543 Disponível em: <http://www.contasabertas.com.br>. Acesso em: 12 out. 2013.

544 Recentemente, o governo anunciou que vai criar uma página no Facebook para o seu "Gabinete Digital”, uma iniciativa do governo para aumentar sua presença nas redes sociais e se aproximar do eleitor-internauta. Disponível em: <http://www1.folha.uol.com.br/poder/2013/08/1330690-planaltodecide-criar-pagina-em-rede-social.shtml>. Acesso em: 23 ago. 2013. 
[...] a busca e a espera por participação massiva é muito menos importante do que garantir que exista um número apropriado de canais e oportunidades para que qualquer cidadão ( todo e qualquer indivíduo concernido e afetado pelo sistema de decisões da comunidade política) possa se tornar participante da esfera pública e da vida política, em conformidade com seu desejo e motivação. ${ }^{545}$

Evidentemente, há autores que divergem desse paradigma da democracia eletrônica. Wolton, ${ }^{546}$ por exemplo, entende que sempre que a sociedade se vê diante de progressos científicos e tecnológicos, atribuem-se-lhe novas possibilidades a articulações em projetos de organização econômica, social e jurídica. Para o autor, as evoluções técnicas não acarretam uma evolução substancial dos modelos sociais e culturais. Ao contrário, as mídias provocam uma urgente necessidade de aceleração das decisões e de sistemas de adequação mal formulados e desenvolvidos para justificar as novas teorias.

Todavia, há mudanças em curso no próprio fazer político, o qual precisa considerar o fato de que a ação pública tem buscado novas formas de organização e de atuação que não necessariamente prescindem do Poder Público, mas que também não querem esperar pelo tempo antes definido apenas por ele. Os institutos da democracia representativa não estão em questão, e as regras majoritárias e a responsabilidade dos eleitos são diligentemente mantidas. Todavia, com efeito, há um ganho em legitimidade de uma decisão pública, quando elaborada por meio de um processo que reúne os protagonistas em torno de um desafio comum. Essa negociação em conjunto mostra-se particularmente necessária em um momento em que códigos e referências diversificadas proliferam. Essa é, ao nosso ver, a vantagem da governança interativa em relação aos métodos tidos como tradicionais de governar.

\section{Como observa Cruz:}

545 GOMES, Wilson; MAIA, Rousiley C. M.; MARQUES, F.P.J.A. Op. cit., p. 41.

546 "Les hommes politiques sont bien placés pour le savoir, qui connaissent la différence qui existe entre vitesse de l'information et dificulte de l'action politique. En démocratie, on le sait, les conditions de l'action sont lentes; toutes les décisions doivent être négociées et mettent du temps à s'inscrire dans les réalités du fait du caractere très institutionnalisé et bureaucratisé de nos sociétés.[...] Les nouvelles techniques accentuent cette logique de l'urgence et gomment l'inévitable complexité de la logique politique.” WOLTON, Dominique. Internet et après? Une théorie critique de nouveaux médias. Paris: Flammarion, 2000, p. 149. 
A teoria da democracia não precisa de novas classificações ou paradigmas. É preciso apenas que ela receba uma nova orientação que consiga captar e interpretar um mundo que vê mudanças diárias trazidas por um mercado da informação e da comunicação totalmente integrados graças às redes eletrônicas, que coloca os indivíduos diante de um mundo sem fronteiras, funcionando em tempo real e de forma permanente. Essa nova maneira de estar no mundo implica um novo estilo de vida, uma comunhão de civilizações, e não mais o choque entre elas, conforme proposto por Huntington. ${ }^{547}$

\subsection{Facebook, Twitter, YouTube, Blogs: conceito, arquitetura e importância}

O contexto contemporâneo testemunha revoluções tecnológicas e sociais de grande fôlego. As mídias, de fato, sempre desempenharam um papel muito importante nos processos de construção cultural e política da sociedade. A diferença é que as mídias sociais conferem nova perspectiva ao termo cidadania, com um público que lê, interpreta e passa adiante as mensagens recebidas. As redes provocaram uma mudança na forma de se comunicar e, ao alterar a comunicação, as modificaram igualmente as relações sociais.

Embora o acesso à rede ainda seja limitado por exigências materiais e culturais evidentes, há de se reconhecer que a Internet (e as potencialidades que ela apresenta) se expande rapidamente e amplia o espaço das fontes de informação. Com isso, a Internet, que, ao mesmo tempo, é onipresente e muito pessoal, atrai novos atores para a esfera de visibilidade pública e cria um novo tipo de relação comunicacional entre Estado, instituições e cidadãos.

Não é a tecnologia que determina a sociedade, são os grupos sociais que a determinam. O ciberespaço, diferentemente de meios tidos como convencionais ${ }^{548}$ (telefone, rádio, impressos em geral) ou dos tradicionais espaços públicos no mundo físico (como uma biblioteca, escola ou aeroporto) permitem, é bem verdade, que a cidadania encontre novas formas para interagir econômica, política e socialmente. Contudo, isso só é possível por ser de interesse dos grupos sociais que isso aconteça.

547 CRUZ, Paulo Márcio. Repensar a democracia. Revista da Faculdade de Direito da UFG, Goiânia, vol. 33, n. 1, jan./jun. 2009.

548 Dizemos isso, pois, a depender da geração, não há nada mais tradicional do que mandar uma mensagem por "WhatsApp", postar sua foto no "Instagram" ou fazer o upload do vídeo da última festa no YouTube. Mandar e-mail seria até um pouco ultrapassado para eles. 
As redes, por conseguinte, constituem o espaço público contemporâneo, um espaço onde os usuários navegam, debatem e compartilham informações e projetos. Possuem uma arquitetura que possibilita associações não hierarquizadas, com acesso simultâneo a várias informações, facultam participação política e transformam a relação do indivíduo com o mundo. A cidadania deve aprender a mover-se nessa arquitetura e ambiente, sendo capaz de refletir e tomar decisões, e dominar novos âmbitos do conhecimento numa sociedade cada vez mais caracterizada por múltiplas telas onde convergem meios e linguagens e onde convivem antigas e novas tecnologias.

\subsubsection{Redes Sociais}

De acordo com Marteletto, ${ }^{549}$ as redes sociais representam “[...] um conjunto de participantes autônomos, unindo ideias e recursos em torno de valores e interesses compartilhados.” A estrutura de uma rede social é descentralizada, dinâmica, sem limites definidos, com capacidade de auto-organização, ${ }^{550}$ formando relações horizontais de compartilhamento e cooperação.

As redes sociais representam um fenômeno coletivo, cuja dinâmica implica relacionamento, seja ele entre pessoas, grupos ou organizações, ou relacionamentos familiares, de amizade, de trabalho ou comunitários. O importante é ser um espaço de conexão que provoca mudanças no conhecimento e na rotina dos indivíduos. Castells vê os elos formados pelas redes sociais como “[...] um conjunto de nós interconectados. [...] Concretamente, o que um nó é depende do tipo de redes concretas de que falamos." 551

Esses canais de diálogo funcionam em um ambiente virtual. Portanto, desde o seu surgimento, as interações sociais mútuas prescindem de um espaço físico para acontecer. O importante é a relação de pertencimento, de trocas comunicativas e

\footnotetext{
549 MARTELETO, Regina M. Análise de redes sociais: aplicação nos estudos de transferência da informação. Ciência da Informação, Brasília, v. 30, n. 1, p. 72, jan/abr. 2001.

550 Segundo Recuero, “[...] o próprio aparecimento de redes sociais na Internet pode ser considerado um comportamento emergente e auto-organizado”. RECUERO, Raquel. Redes sociais na Internet. Porto Alegre: Sulina, 2009, p. 90 (Coleção Cibercultura).

551 CASTELLS, Manuel. Op. cit., 2012, p. 498.
} 
relacionais, porquanto “[...] o que constitui e mantém o grupo são as interações, e não o território". 552

Davenport $^{553}$ anota que o real valor das redes sociais está na possibilidade de compartilhamento de informações - como a informação política - que colaboram para ampliar vozes, redefinindo agendas educacionais e políticas, cooperando para a inovação e para a conscientização de mudanças pessoais.

Diante disso, serão feitos breves comentários sobre as redes sociais que seguem, além dos blogs, por eles se mostrarem os veículos de comunicação mais utilizados pelos políticos, durante as últimas eleições brasileiras.

\subsubsection{Facebook}

A história do surgimento do Facebook é bem conhecida. Essa rede social foi criada por Mark Zuckerberg e por seus colegas de quarto, em 2004, quando todos cursavam a Universidade de Harvard. Em um dado momento, desenvolveram uma forma virtual de compartilhamento de dados que avisaria sobre as aulas, exames, ou daria informações gerais sobre a faculdade. Com o tempo, obteve um uso mais social, ao exibir fotos dos amigos e familiares e informações pessoais. ${ }^{554} \mathrm{Em} \mathrm{2006}$, essa rede social se abriu a todos os usuários da Internet e, no ano de 2012, atingiu a marca de 1 bilhão de usuários ativos. ${ }^{555}$

Para usar o Facebook é necessário se registrar no site, criando, em seguida, um perfil pessoal. O próximo passo é adicionar os amigos, isto é, o usuário identifica seus amigos ou as pessoas que deseja ter em seu círculo de relacionamento e envia-lhes um convite virtual, que poderá ser aceito ou não. A pessoa que aceita o convite aparece em seu Facebook, e assim é formado seu círculo de amizades, com a possibilidade de troca

552 RECUERO, Raquel. Op. cit., p. 151.

553 DAVENPORT, Thomas. Saving its soul: human-centered information management. Harvard Business Review, v. 72, n. 2, p. 119-131, mar./apr. 1994.

554 Disponível em: <http://g1.globo.com/platb/o-perfil-do-facebook/>. Acesso em: 4 set. 2013.

555 Disponível em: <http://noticias.r7.com/tecnologia-e-ciencia/noticias/facebook-tem-mais-de-umbilhao-de-usuarios-ativos-comemora-mark-zuckerberg-20121004.html?question=0>. Acesso em: 4 out. 2012. 
de mensagens, participação em grupos de interesse, postagem de fotos e até venda de produtos.

No Brasil, essa rede social possui grande aceitação e tem conquistado cada vez mais usuários. O objetivo mais recente parece ser expandir seu uso nos celulares e smartphones, tanto que a rede social tem buscado parcerias com as principais operadoras de telefonia do país, para fornecer acesso gratuito à sua página na Internet pelo celular. ${ }^{556}$

Polêmica que envolve essa ferramenta atinge o direito à privacidade. ${ }^{557} \mathrm{O}$ Facebook armazena informações do histórico do usuário e de todos os seus amigos, tendo acesso às atividades e gostos de todos que possuem perfil em suas páginas, mesmo depois do dado ou informação ter sido deletado. Seus controladores também sabem se o usuário acessou sua página de um lugar diferente do habitual. A crítica é que, além de eles poderem terceirizar essas informações com efeitos comerciais, muitos dados são armazenados à revelia, e são copiados e distribuídos com facilidade a qualquer pessoa autorizada pelo Facebook. São dados pessoais que circulam de forma mais abrangente do que a autorizada, pelo menos, a priori.

Na Europa, onde regras de proteção à privacidade são mais rigorosas do que nos Estados Unidos, foi criada a organização “Europe vs. Facebook”, ${ }^{558}$ que já obteve algumas conquistas, como obrigar o Facebook a desativar, na Europa, seu sistema de reconhecimento facial, que identificava automaticamente o rosto das pessoas em fotos de terceiros.

O Facebook alega que os usuários consentem em disponibilizar seus dados pessoais. Realmente, para instalar o Facebook, o usuário deve aceitar uma série de termos e condições. Entretanto, o indivíduo não pode contestar os termos parcialmente

\footnotetext{
556 Facebook fecha acordo com operadoras para acesso grátis. Disponível em: $<$ http://www1.folha.uol.com.br/fsp/mercado/122049-facebook-fecha-acordo-com-operadoras-paraacesso-gratis.shtml>. Acesso em: 3 ago. 2013.

557 O site de busca Google também teve que mudar sua política de privacidade depois de receber várias críticas de organizações europeias e de procuradores federais dos Estados Unidos que tratavam sobre a invasão de privacidade, no compartilhamento automático de dados pessoais em outros serviços do conglomerado da empresa. O lobby das empresas de Internet, por sua vez, se une para desenvolver a autorregulamentação e argumenta que qualquer lei é nociva à liberdade.

558 Disponível em: <http://europe-v-facebook.org/EN/en.html>. Acesso em: 15 ago. 2013.
} 
e, por isso, acaba se submetendo a eles. Isso quando os termos são efetivamente lidos. ${ }^{559}$ Agravam o cenário as atualizações automáticas realizadas, ao longo do uso dessa rede social, que não informam ao usuário exatamente o que está sendo feito, o que parece ser uma prática arbitrária.

Ora, o fato de alguém colocar conteúdo pessoal nesse site não implica permissão para sincronizar números de seu telefone celular, nem para importar todos os contatos de seu e-mail, muito menos autorização para identificar (o termo usado na página é “marcar”) outros usuários em fotos ou vídeos.

Nesse sentido, aliás, há manifestação jurisprudencial negando propaganda eleitoral extemporânea no Facebook, posto que essa rede permite que a foto de alguém seja "marcada” e usada em outro contexto, sem o prévio conhecimento daquele que teve sua imagem indevidamente utilizada:

RECURSO. PROPAGANDA ELEITORAL EXTEMPORÂNEA. FACEBOOK. PRÉVIO CONHECIMENTO. NÃO OCORRÊNCIA. 1. A propaganda eleitoral antecipada deve ser instruída com prova da autoria ou do prévio conhecimento do beneficiário. 2. Hipótese em que a divulgação irregular de panfleto no perfil do facebook do précandidato foi feita por terceiro, não havendo prova do prévio conhecimento do demandado. 3. Recurso improvido. ${ }^{560}$

Ainda em relação à propaganda eleitoral, salienta-se que os tribunais regionais têm-se posicionado de forma a não aceitar essa rede como meio propício à prática de propaganda eleitoral, pois as manifestações se reduzem ao círculo de amizades. Como exemplo:

559 Pesquisa da organização Big Brother Watch, por exemplo, afirmou em 2012 que 9 entre 10 pessoas que usam o Google não leram sua nova política de privacidade. Disponível em: <http://www.bigbrotherwatch.org.uk/home/2012/02/ten-people-havent-read-googles.html>. Acesso em: 1 jan. 2013.

560 BRASIL. TRE-PE. Recurso Eleitoral $n^{\circ}$ 7-77.2012.6.17.0005. Juiz Relator Luiz Alberto G. de Faria, que motivou a sentença nos seguintes termos: "Na presente hipótese, observo que o veículo utilizado para a divulgação da propaganda irregular foi o facebook, rede de informação social que, de fato, possibilita que alguém, na melhor ou pior intenção, faça constar do perfil de outrem conteúdo qualquer que desejar inserir, não se fazendo necessária para tanto a prévia aceitação daquele em cuja página far-se-á a inclusão do expediente. Tal prática é comum nesse sistema de comunicação, sendo conhecida na linguagem dos usuários como 'marcar algo'. Dentro desse contexto, o prévio conhecimento a que se refere a legislação de regência como condição para a aplicação da reprimenda correspondente à conduta em apreço (art. 1o, §4 $4^{\circ}$, daRes. TSE $n^{\circ}$ 23.370/11), tratando-se do meio de difusão em comento (facebook), mostra-se de difícil caracterização, de modo que tenho por plausível a alegação do suplicado, no sentido de que apenas teve conhecimento da postagem em seu perfil após a sua efetiva veiculação por um 'seguidor' seu.” 
RECURSO ELEITORAL - PROPAGANDA ELEITORAL REALIZADA NA ITERNET - UTILIZAÇÃO DE REDE SOCIAL FACEBOOK - NÃO CARACTERIZAÇÃOO - INEXISTÊNCIA DE PROPAGANDA IRREGULAR - EXISTÊNCIA APENAS DE MANIFESTAÇÃO DE PREFERÊNCIA POLÍTICA SEM AFRONTA AO ORDENAMENTO JURÍDICO E À IGUALDADE DE OPORTUNIDADES ENTE OS CANDIDATOS. RECURSO CONHECIDO E NÃO PROVIDO. 1. A utilização por parte de eleitores de perfis e comunidades em sites de relacionamento na Internet, tais como Facebook, Orkut e MySpace para enaltecerem ou criticarem candidatos não configura propaganda eleitoral. ${ }^{561}$

Como sempre, é fundamental priorizar o uso dessas ferramentas tecnológicas para o incremento da comunicação e da democracia. O espaço virtual deve servir como mais um espaço público para intercâmbio democrático de ideias e opiniões e para a reflexão política, ao invés de ser empregado para práticas prejudiciais à cidadania. É fato que tem havido o desenvolvimento de práticas de vigilância sobre os hábitos dos indivíduos, as quais precisam ser coibidas ao redor do mundo.

Merece destaque a pesquisa conduzida pelo Facebook, em conjunto com a Universidade da Califórnia, apresentada na revista Nature ${ }^{562}$ de publicação on-line, e que sugere que uma mensagem publicada no Facebook durante as eleições norteamericanas de 2010 resultou em 340 mil votos adicionais em todo o país.

Segundo os próprios investigadores, o estudo foi o primeiro a demonstrar que as redes sociais provocam impacto, mesmo que limitado, sobre as eleições.

O procedimento implicava mandar a todos os usuários do Facebook com mais de 18 anos, que acessassem sua página pessoal, em 2 de novembro de 2012, dia das eleições para o Congresso americano, algumas mensagens. Cerca de 600 mil usuários (1\% do total) recebeu mensagens informativas que encorajavam o voto: "vá votar", "hoje é dia de eleição”, além de um link para os locais de votação e uma opção de clicar no botão "votei”, que registrava o número total de usuários que afirmavam já terem votado. O segundo grupo, composto de 60 milhões de usuários (98\% do total) recebia as mesmas mensagens, com uma diferença: ao clicar no botão “votei”, ele também tinha

561 BRASIL. TRE-MT. Processo $n^{\circ}$ 40827, Classe RE. Acórdão no 22241, de 25/09/2012, Relator Doutor Sebastião de Arruda Almeida, publicado em sessão, no dia 25/09/2012.

562 Disponível em: <http://www.nature.com/news/facebook-experiment-boosts-us-voter-turnout1.11401>. Acesso em: 31 dez. 2013. 
acesso às fotos de seis de seus amigos que estariam, manifestadamente, na lista de eleitores. O restante (1\%) não recebeu mensagem alguma. Os pesquisadores afirmam que os grupos foram formados aleatoriamente.

Examinando as listas de votação, os investigadores puderam comparar o real comparecimento às urnas e concluíram que as mensagens as quais disponibilizavam fotos de amigos que votaram foram diretamente responsáveis por 60 mil votos a mais, em todo o país; em acréscimo, outros 280 mil votos foram gerados indiretamente, provenientes de eleitores que foram convencidos a votar por amigos de amigos. A rede social, assim, teria condições de quadruplicar o efeito da mensagem.

É um dos raros estudos a tentar quantificar o impacto direto das redes sociais nas eleições, o que é muito difícil de ser aferido, não só pelo número de pessoas envolvidas, mas, principalmente, pela veracidade das informações. Como saber que todos que clicaram no botão "eu votei” realmente votaram?

No caso desse estudo, há dois outros agravantes. O Facebook estava sendo analisado e, ao mesmo tempo, conduziu a pesquisa, o que compromete a isenção necessária para a comprovação de uma investigação. Além disso, essa rede virtual tem uma orientação política claramente definida, já que Mark Zuckerberg prestou apoio ao presidente Barack Obama, o que também pode ter influenciado o comportamento do usuário. O que deve ficar dessa experiência, no entanto, é a percepção cada vez mais atual de que a tecnologia adentra de tal forma a vida em sociedade que seus efeitos também atingirão a participação política. Por ser apenas um instrumento, fica a depender da sociedade o modo de sua utilização. Como a presença de comentários e manifestações políticas na Internet é cada vez maior, acreditamos que essa relação Internet e mídias sociais produz frutos positivos para a democracia.

\subsubsection{Twitter}

O Twitter é o mais popular micro-blogging ${ }^{563}$ em atuação. Enquanto o blog é um diário que pode ser escrito por qualquer pessoa e que não possui definição de tamanho, o micro-blogging é a publicação de postagens de tamanho limitado. No caso

563 Outros exemplos de micro-blogging são o Cocoloop, Meme e Tumblr. 
do Twitter, o limite é de 140 caracteres. Foi lançado em 2006 e já foi muito usado no Brasil, mas, de uns anos para cá, tem perdido usuários e busca uma reformulação para resgatar a atenção dos brasileiros. ${ }^{564}$

De acordo com dados do portal ComScore, ${ }^{565}$ que pesquisa o uso das tecnologias no mundo, a audiência total do site, em 2011, era de 12,9 milhões de brasileiros. Um ano mais tarde, era de 9,7 milhões, uma queda de 24\% da audiência, no Brasil. O cenário tem sido revertido com a ajuda dos jovens, os quais têm perdido interesse pelo Facebook e se voltam novamente ao Twitter. Hoje em dia, o Brasil é o quinto país com maior número de usuários ativos. ${ }^{566}$

É uma rede social na qual o indivíduo publica conteúdo para seus contatos e recebe publicações desses contatos. Portanto, a comunicação ocorre em um ambiente reduzido e selecionado pelo usuário que, em princípio, busca manter relacionamento com pessoas que tenham os mesmos interesses que os seus.

O primeiro passo para usar o Twitter é abrir uma conta na página da rede social e montar o perfil, personalizando sua página. Se, no Facebook, a palavra de ordem é “curtir”, pois as pessoas “curtem” o que as outras exibem, no Twitter é “follow”, isto é, se o indivíduo se interessou pelo Twitter de alguém, precisa acompanhar ou seguir (“follow”) as atualizações do usuário. Assim, é indispensável a manifestação desse interesse para poder saber o que uma outra pessoa está escrevendo. Da mesma maneira, esse indivíduo também precisa ser seguido para que a troca de informações seja estabelecida. O comentário postado recebe o nome de "twittada”. Se o usuário gosta da “twittada” de alguém, pode reproduzi-la em seu perfil, o que se denomina "retwittar".

Além disso, é possível que um usuário seja bloqueado por outro. Em 2013, a rede chegou a anunciar uma alteração nessa regra, informando que usuários bloqueados passariam a ter acesso às mensagens publicadas por quem os havia bloqueado, e

\footnotetext{
564 O Twitter é a rede social que mais cresce no mundo. No Brasil, ele possui uma página na Internet que anseia traçar um perfil de seus usuários no país: <http://twittercentral.com.br/censo/> .

565 Disponível em: <http://www.comscore.com>. Acesso em: 10 set. 2012.

566 Disponível em:< http://www.otempo.com.br/interessa/brasil-\%C3\%A9-o-quinto-pa\%C3\%ADs-commaior-n\%C3\%BAmero-de-usu\%C3\%A1rios-ativos-no-twitter-1.749425>. Acesso em: 29 nov. 2013.
} 
poderiam interagir com elas, o que sempre havia sido impossível pela arquitetura da rede, que só admite participação de pessoas autorizadas.

A insatisfação dos usuários foi prontamente disseminada, dada a velocidade da Internet. Foram tantas as reclamações que a medida teve vida muito curta, apenas de algumas horas, e o Twitter voltou a funcionar como antes.

O Twitter ganhou destaque durante a Primavera Árabe. ${ }^{567}$ Essa ferramenta foi adotada para mobilizar os cidadãos na luta pela conquista de princípios democráticos para aquela região, de cultura muito diferente da do Ocidente. A preservação dos canais de informação é fundamental para o estabelecimento de um Estado democrático de Direito. Na ausência de canais de expressão livre, o Twitter foi um exemplo de como as redes sociais podem ser úteis a processos democratizantes. ${ }^{568}$ Ademais, é fácil de ser usado e a comunicação é necessariamente rápida.

Sinal de que as redes sociais são capazes de dar voz aos cidadãos, servindo como uma potente plataforma para a divulgação de mensagens e reunião dos manifestantes.

\subsubsection{YouTube}

O YouTube não é exatamente uma rede social, mas um site de compartilhamento de vídeos. Permite a seus usuários que carreguem seus vídeos feitos digitalmente e os partilhem com outros internautas. Apesar de não ser uma rede social, é uma ferramenta de grande visualização na Internet e que se mostra essencial para as campanhas políticas, ${ }^{569}$ além de possibilitar acesso a propagandas políticas e discursos

567 Onda revolucionária de manifestações e protestos que começaram no Oriente Médio e norte da África, em dezembro de 2010, na Tunísia, e pleiteiam abertura política, fim da repressão e da censura à Internet.

568 Também foi usado em outras manifestações políticas: “[...] se utilizó politicamente por ejemplo en EEUU durante la campaña electorale; en China, por los dissidentes, y también en España - en esta última el debate televisivo entre los candidatos Rodríguez Zapatero (PSOE) y Mariano Rajoy (PP) durante las elecciones presidenciales de 2008, se siguió muy de cerca con intercambio de opiniones a través de Twitter.” MACIEL, Guillermo. Op. cit., p. 61.

569 “Según la empresa de medición de audiências Nielsen//NetRatings 65,000 videos son colocados y 100 millones de grabaciones son vistas diariamente en YouTube. Mensualmente, esta página de videos y audio recibe más de 20 millones de visitas, por lo que los políticos están tomando conciencia de la importancia que tienen sitios como éste que funcionan como fuentes de información 
políticos feitos no passado, colaborando para a formação de uma memória histórica do país.

Hospeda vídeos, filmes, videoclipes e materiais caseiros. Foi fundado em 2005 e, no seguinte, foi adquirido pelo Google por US\$ 1,65 bilhões. Segundo o site de pesquisas e análises Nielsen NetRatings, o usuário médio do YouTube gasta 26 minutos por mês diante dos vídeos postados no site. Em média, 65 mil novos vídeos são postados por dia. ${ }^{570}$

O YouTube tem sido alvo de ações de censura em vários países, por conta do conteúdo veiculado, tendo sido bloqueado em vários países, como Irã, Síria, Sudão, Tunísia e China. No Brasil, o site também já foi bloqueado integralmente no ano de 2007, cumprindo ordem judicial do desembargador Ênio Zuliani, do Tribunal de Justiça de São Paulo, que havia determinado, na verdade, bloqueio de um vídeo específico, em que uma modelo e apresentadora brasileira aparecia em uma praia com seu namorado trocando carícias. À época, funcionários do site explicaram que era impossível retirar apenas um determinado vídeo do ar, já que eles são publicados pelos próprios usuários, e a identificação pode ser imprecisa.

Diante da repercussão negativa de censura no Brasil por motivo irrelevante, o desembargador, alguns dias depois do fato, reformou sua decisão e o site votou ao ar. Depois disso, conseguiu-se remover apenas o site provocador da discussão.

O YouTube é alvo frequente de ações de políticos e personalidades que exigem retirada de vídeos do ar, em constantes embates que envolvem direito à privacidade e leis eleitorais, de um lado, e direito à informação, liberdade de expressão e livre manifestação de pensamento, do outro. Já foram focalizadas ementas que condenam o Google, proprietário do YouTube, por veicular propaganda eleitoral antecipada ou na qual tenha havido algum tipo de trucagem ou mixagem nas imagens. Isso não quer dizer que o advento do processo eleitoral dê azo para a retirada de toda e qualquer postagem na Internet. Senão, vejamos:

no convencionales.” MACIEL, Guillermo. Del videopoder a la ciberpolitic@. Montevideo: Editorial Técnica, 2009, p. 46.

$570 \quad$ Disponível em: <http://tecnologia.terra.com.br/noticias/0,,OI1182065-EI12884,00Google+confirma+compra+do+YouTube+por+US+bi.html>. Acesso em: 26 de dez. 2013. 
RECURSO ELEITORAL. ELEIÇÕES 2012. INTERNET. YOUTUBE. PROPAGANDA ELEITORAL IRREGULAR. I PRELIMINAR. Ausência de citação válida. Citação dirigida ao fax da recorrente. Rejeição. II - PRELIMNAR. Intempestividade do recurso. Duplicidade de intimação. Tempestividade reconhecida. Rejeição. III MÉRITO. Vídeo que reproduz participação voluntária do candidato em programa humorístico. Ausência de conotação eleitoral. Propaganda eleitoral irregular não configurada. IV - Provimento do recurso. Improcedência da representação. I - Em se tratando de representação por propaganda eleitoral irregular, é válida a citação realizada através do envio de fac-símile ao número de uma das sedes da empresa responsável pelo sítio no Brasil.II - Em homenagem ao princípio da ampla defesa, se houve duplicidade de intimação da sentença, que se realizou mediante publicação em cartório e, posteriormente, por mandado, por tal erro não poderá responder a parte, devendo prevalecer a mais benéfica a parte recorrente. III - A presença de vídeo no youtube com a participação voluntária de candidato em programa humorístico da televisão, veiculado originalmente em período não eleitoral, não configura propaganda eleitoral irregular.IV - Recurso a que se dá provimento para julgar improcedente a representação. ${ }^{571}$

A reforma eleitoral de 2009 fixou que o provedor de conteúdo só é responsável pelo material postado se tiver conhecimento prévio de seu conteúdo, aplicando-se-lhe sanções legais pela divulgação apenas se houver descumprimento de decisão exigindo retirada do vídeo.

O Marco Civil da Internet, assim que aprovado, garantirá maior proteção aos provedores, em face do previsto em seu art. 14: “O provedor de conexão à Internet não será responsabilizado civilmente por danos decorrentes de conteúdo gerado por terceiro.”

\subsubsection{Blogs}

O termo weblog foi cunhado por Jorn Barger, em 17 de dezembro de 1998. Peter Merholz foi quem abreviou o termo para blog, alguns meses depois, em maio de 1999, ao desmembrar a palavra para formar a frase “we blog” (“nós blogamos”) em seu site. ${ }^{572} \mathrm{E}$, desde então, os blogs fazem parte do cotidiano da comunicação na Internet. ${ }^{573}$

\footnotetext{
571 BRASIL. TRE-PB - RE: 18592 PB. Relator: TERCIO CHAVES DE MOURA, Data de Julgamento: 23/10/2012, Data de Publicação: PSESS - Publicado em Sessão, Volume 15:27, Data 23/10/2012.

572 Disponível em: <http://www.wired.com/entertainment/theweb/news/2007/12/blog_anniversary>. Acesso em: 12. jul. 2013.
} 
No início, eram diários on-line, páginas elaboradas por qualquer pessoa para tratar sobre qualquer tema. A criação de um blog exige poucas habilidades do internauta, é de fácil manuseio e a grande maioria das plataformas para desenvolvimento de um blog são gratuitas, motivos que promoveram sua rápida expansão. Qualquer tipo de informação pode ser colocado em um blog, como imagens, gráficos, bancos de dados, pois não há limite na sua extensão. Não há solicitações de amizade, de sorte que qualquer pessoa pode acessar a página de um blog, bastando ter interesse.

O conceito de blog parece ter superado o patamar de diário pessoal, assumindo uma configuração mais significativa, voltada à formação de ação política. Muitos jornalistas possuem seus próprios blogs, assim como representantes de empresas e políticos, ${ }^{574}$ o que contribui para um diálogo livre e aberto entre a sociedade civil e os personagens da mídia e das estruturas de poder político e econômico. ${ }^{575}$ Esses blogs participam ativamente da cobertura política do país, analisando as campanhas, disponibilizando comentários, soltando matérias em primeira mão. Por ser um espaço de atuação independente, os blogs colaboram para o fortalecimento da liberdade de expressão e da democracia.

Yoani Sánchez, jornalista e blogueira cubana, atraiu a visibilidade internacional para a situação social em Cuba sob o governo de Fidel Castro e seu sucessor, Raúl Castro, através de seu blog Generación Y. ${ }^{576}$ É através dessa plataforma que a jornalista é capaz de exercer o direito à liberdade de expressão, tão cerceado na ilha. Em seu blog, Yaoni já tratou sobre o sistema de filtragem imposto pelo governo

573 O número de blogs no mundo, em 2006, era de 35 milhões, saltando para 173 milhões em 2011. Disponível em: <http://www.statista.com/statistics/278527/number-of-blogs-worldwide/>. Acesso em: 21 jan. 2013.

574 Como referência, Ricardo Noblat, Luis Nassif, Marcelo Leite ou Cristiana Lôbo. A presidente Dilma Roussef também possui o seu "Blog da Dilma”. Segundo Foletto, o crescimento dos blogs com informação jornalística decorre da insatisfação com as notícias veiculadas nos meios de comunicação de massa, observada na sociedade civil, cuja percepção da manipulação de informações e da falta de reflexões aprofundadas sobre temas diversos tem atraído os cidadãos para espaços desvinculados dos grandes conglomerados midiáticos. In: FOLETTO, Leonardo. Blogosfera x Campo jornalístico: aproximação e consequências. São Paulo: Momento, 2009, p. 199.

575 Na obra Sociedade em rede, Castells anota que os blogs são um novo espaço de ação política, por representarem arquivos abertos onde se colocam imagens, vídeos e comentários capazes de diminuir a barreira entre o público e o privado.

576 Disponível em: <http://lageneraciony.com/>. Acesso em: 25 nov. 2013. Maciel afirma que seu blog já chegou a ter 1,2 milhão de visitas por mês. MACIEL, Guillermo. Op. cit., p. 59. 
cubano, que impede que sua página seja acessada em Cuba. Mesmo com esse controle, seu blog ganhou projeção internacional e pode ser acessado em vários países, recebendo tradução em 15 idiomas.

Em 2009, a blogueira enviou perguntas relacionadas aos impasses que dificultam a abertura das relações entre Cuba e Estados Unidos ao presidente norteamericano, Barack Obama. Seu propósito era encontrar soluções de superação para essa disputa. As mesmas questões foram encaminhadas ao presidente cubano Raúl Castro. As respostas dadas por Obama foram publicadas no site Generación Y e Castro não chegou a respondê-las.

Dois anos mais tarde, em 2011, a rede de informações estatais de Cuba noticiou, com base em informações obtidas junto ao WikiLeaks, que essa entrevista, na verdade, nunca foi de fato respondida pelo presidente norte-americano, tratando-se de alguma manobra da "cibermercenária” (como Yoani é tratada pelo governo de Cuba) e dissidente política, para difamar mais uma vez o país e o governo. ${ }^{577}$

Por outro lado, a facilidade de criação dos blogs pode gerar o problema da responsabilização, em caso de abusos e ofensas.

Em regra, aquele que se sente ofendido por notícia veiculada na mídia tradicional ingressa com uma ação de reparação de danos junto ao Poder Judiciário. Entretanto, a responsabilização pelo que é escrito em um blog pode ser mais difícil, tendo em vista nem sempre ser possível saber a real identidade do blogueiro. Afinal, a elaboração do blog não exige a confirmação de dados pessoais, o perfil do escritor pode ser inventado, e, por ser gratuito, os dados de cartão de crédito, por exemplo, não são fornecidos. Com o intuito de sanar essa lacuna, foi apresentado na Câmara dos Deputados o Projeto de Lei $n^{\circ} 7.131 / 2010$, de autoria do Deputado Gerson Peres (PP/PA), que tramita em regime de urgência nessa casa. ${ }^{578}$

\footnotetext{
577 A matéria jornalística que veiculou a notícia está disponível em: <http://www.youtube.com/w atch?v=J_mp2aZ4Ve0>. Acesso em: 23 nov. 2013.

578 andamento do projeto está disponível em: <http://www.camara.gov.br/proposicoesWeb/fichadetramitacao?idProposicao=473385>. Acesso em: 29 dez. 2013.
} 
Esse projeto de lei que dispõe sobre a responsabilidade de proprietários e autores de blogs tem recebido críticas em razão de seu caráter genérico. A justificativa se baseia em informações sobre o crescimento da Internet e afirma terem surgido novas possibilidades de manifestação de pensamento trazidas pela rede virtual, mas deixa de apresentar argumentos que justifiquem a necessidade de uma reponsabilidade específica para os blogs, e o próprio projeto prescinde de definições exatas e úteis para a determinação da culpabilidade.

Outrossim, conforme o art. $3^{\circ}$ do projeto de lei, caso haja a impossibilidade de identificação do verdadeiro autor do crime contra a honra eventualmente atestado em um blog, a responsabilidade recairá sobre “[...] editores, proprietários e autores dos blogues, fóruns, e demais sítios de Internet com funcionalidades semelhantes.”

A esse respeito, parece ser difícil que o autor ou editor de um blog seja capaz de identificar com exatidão aquele que fez um comentário agressivo em sua página. A despeito de a Constituição Federal vedar o anonimato, expressamente, em seu texto (art. $5^{\circ}, \mathrm{IV}, \mathrm{CF}$ ), é impossível manter um controle absoluto sobre a identidade de todos os internautas. A responsabilização de um blogueiro por atos anônimos ou perniciosos de outrem também afeta os valores constitucionais e não pode ser admitida, pois, nesse caso, se defenderia a honra do ofendido, mas com graves afrontas à liberdade de expressão.

Mais acertada é a sugestão do art. $4^{\circ}$ desse projeto de lei, que prevê a obrigatoriedade de um cadastro nacional de blogueiros, acompanhado do registro gratuito do blog no site governamental "registro.br".

Enquanto esse projeto não é votado ou incrementado, já é possível encontrar jurisprudência sobre o tema. Destaca-se o exemplo a seguir:

1. A exploração comercial da Internet sujeita as relações de consumo daí advindas à Lei $\mathrm{n}^{\circ}$ 8.078/90. 2. O fato do serviço prestado pelo provedor de serviço de Internet ser gratuito não desvirtua a relação de consumo, pois o termo "mediante remuneração" contido no art. $3^{\circ}$, § $2^{\circ}$, do CDC, deve ser interpretado de forma ampla, de modo a incluir o ganho indireto do fornecedor. 3. A fiscalização prévia, pelo provedor de conteúdo, do teor das informações postadas na web por cada usuário não é atividade intrínseca ao serviço prestado, de modo que 
não se pode reputar defeituoso, nos termos do art. 14 do CDC, o site que não examina e filtra os dados e imagens nele inseridos. 4. $\mathrm{O}$ dano moral decorrente de mensagens com conteúdo ofensivo inseridas no site pelo usuário não constitui risco inerente à atividade dos provedores de conteúdo, de modo que não se lhes aplica a responsabilidade objetiva prevista no art. 927, parágrafo único, do CC/02.5. Ao ser comunicado de que determinado texto ou imagem possui conteúdo ilícito, deve o provedor agir de forma enérgica, retirando o material do ar imediatamente, sob pena de responder solidariamente com o autor direto do dano, em virtude da omissão praticada.6. Ao oferecer um serviço por meio do qual se possibilita que os usuários externem livremente sua opinião, deve o provedor de conteúdo ter o cuidado de propiciar meios para que se possa identificar cada um desses usuários, coibindo o anonimato e atribuindo a cada manifestação uma autoria certa e determinada. Sob a ótica da diligência média que se espera do provedor, deve este adotar as providências que, conforme as circunstâncias específicas de cada caso, estiverem ao seu alcance para a individualização dos usuários do site, sob pena de responsabilização subjetiva por culpa in omittendo. ${ }^{579}$

Nesse recurso, o diretor de uma faculdade de Minas Gerais pleiteava danos morais por frases emitidas em um blog hospedado em uma plataforma de propriedade do Google. Ficou entendido que as transações na Internet são relações de consumo sujeitas ao Código de Defesa do Consumidor, mesmo quando não há cobrança de nenhum serviço. Demais disso, a empresa deve garantir a inviolabilidade dos dados de seus usuários, pois isso pode ser equiparado a uma quebra de sigilo, vedada pelo art. $5^{\circ}$, XII da CF, e não se lhe aplica a obrigatoriedade de exercer o controle prévio do conteúdo das informações postadas no site por terceiros. Exarou-se, ainda, que a liberdade de expressão possui limites e, por conseguinte, ofensas devem ser coibidas.

Se cotejada essa orientação ao projeto de lei $n^{0} 7.131 / 2010$, a sugestão da elaboração de um cadastro de internautas seria aceita, pois é um mecanismo hábil contra o anonimato e capaz de reduzir as ofensas.

Por outro lado, uma análise prévia do conteúdo a ser veiculado pela empresa responsável pelo blog seria declarada inconstitucional.

579 BRASIL. STJ - REsp: 1192208 MG 2010/0079120-5. Relator: Ministra Nancy Andrighi. Data de Julgamento: 12/06/2012, T3 - Terceira Turma, Data de Publicação: DJe 02/08/2012. 
Portanto, esse projeto de lei ainda carece de debates que enfrentem de forma mais clara a atualidade das situações que ocorrem em ambiente virtual, devendo ser revisto e aprimorado.

Na verdade, estamos no meio de uma revolução informacional. A mudança está em andamento. Ainda não existem - e nunca existirão - respostas legislativas suficientes a resolver os conflitos entre liberdade de expressão e direitos individuais. Por isso, a atuação do Poder Judiciário é tão importante, para a análise caso a caso, principalmente a Justiça Eleitoral, pois “[...] o espectro eleitoral descortina, a cada pleito, uma série de inovações, impondo aos analistas renovado esforço na reconstrução dos vários e diversificados escaninhos que compõem o processo eleitoral.”580

\subsection{Uma perspectiva do uso Internet nos recentes quadros eleitorais brasileiros}

O desenvolvimento desta tese se deu no sentido de afirmar ser benéfico para a cidadania e para a democracia o aproveitamento da arquitetura oferecida pela Internet, suas mídias e canais de manifestação, por elas representarem mais uma alternativa de esfera pública, complementar à esfera tradicional e apta a promover a aproximação entre os atores políticos. O objetivo do presente item é, nesse sentido, apontar os fóruns de discussão virtuais utilizados para debate de propostas políticas nos mais recentes quadros eleitorais brasileiros, buscando inferir a lógica de utilização dessas plataformas pelos candidatos e partidos políticos, o alcance conquistado por elas e o grau de heterogeneidade da discussão.

A investigação não possui um recorte específico. Essa decisão foi tomada pelo fato de a Internet ainda ser uma ferramenta de uso incipiente nas eleições brasileiras, ${ }^{581}$ principalmente se comparado ao paradigma colocado pelas eleições presidenciais norteamericanas de 2008. No Brasil, os estudos nessa área são recentes, começam a ganhar

580 CAGGIANO, Monica H. S. Eleições municipais de 1996, com ênfase para o quadro de São Paulo. Revista da Faculdade de Direito Universidade de São Paulo, São Paulo, ano 1, n. 1, v. 91, p. 334, 1996.

581 Conforme registra Caggiano: "Paradoxalmente, porém, a rede foi pouco explorada, deixando de evidenciar todo seu potencial de difusão das mensagens eleitorais e capacidade de arrecadação de recursos financeiros.” CAGGIANO, Monica H. S. O cidadão-eleitor, jogador com veto no processo eleitoral democrático: aspectos polêmicos e peculiares do cenário brasileiro. Eleições gerais 2010. In: INSTITUTO VICTOR NUNES LEAL (Org.). Op. cit., p. 271. 
volume em 2006, quando 25\% do eleitorado tinha acesso à Internet. ${ }^{582}$ Sendo assim, a opção se deu por investigar se tem havido um aumento progressivo das redes virtuais no processo político, podendo, sem limitações feitas a priori, apontar se há diferença no uso da Internet nas eleições municipais e presidenciais. Por fim, a análise mais abrangente consegue superar, de certa forma, o desafio metodológico trazido pela dificuldade de acompanhar o ritmo de crescimento do uso do Facebook e do Twitter, ou o aumento do número de blogs no país. A análise de cada um deles pode sugerir trabalhos específicos. Entretanto, a investigação mais ampla permite a discussão sobre a evolução do emprego da Internet para o fortalecimento da cidadania brasileira, por isso a escolha procedimental adotada.

A difusão da Internet ocorre mundialmente, a partir da década de 1990. Nesse período, a Internet restringia-se, no Brasil, a órgãos estatais e empresas. Sua propagação em ambientes domiciliares acontece de maneira intensa apenas nos anos 2000, quando também são lançadas as redes sociais. Segundo dados do IBOPE, ${ }^{583}$ ao final de 2012, havia 94,2 milhões de pessoas com acesso à Internet, em suas casas, trabalhos, escolas ou lan houses. ${ }^{584}$ Em 2013, o número de brasileiros usando a rede chegou a 105 milhões. ${ }^{585}$ Percebe-se, portanto, um crescimento expressivo do uso da Internet no país. Apesar de ser um meio relativamente novo, trata-se de um fenômeno em rápida evolução, fato estratégico para viabilizar a comunicação política nesse ambiente.

Quanto às campanhas eleitorais, a primeira a incorporar a Internet entre os seus veículos de comunicação com maior atenção foi a de José Serra, candidato do PSDB nas eleições de 2002. ${ }^{586}$ Foi criado o "Pelotão 45", ${ }^{587}$ uma convocação de militantes e

582 “Apenas para que fique claro o tamanho do universo do qual estamos falando, vale a pena lembrar que o acesso à Internet no Brasil ainda é limitado a 25\% do eleitorado. Um percentual bastante semelhante àquele encontrado nos Estados Unidos em 1996.” BARROS FILHO, Clóvis; COUTINHO, Maurício; SAFATLE, Vladimir. Os usos das novas mídias na campanha presidencial de 2006. In: LIMA, Venício Artur de. A mídia nas eleições 2006. São Paulo: Fundação Perseu Abramo, 2007, p. 91.

583 Disponível em: <http://www.ibope.com/pt-br/relacionamento/imprensa/releases/Paginas/942milhoes-de-pessoas-tem-acesso-a-internet-no-Brasil.aspx>. Acesso em: 23 dez. 2013.

584 Lan house é um estabelecimento comercial onde as pessoas pagam para usar um computador com acesso à Internet.

585 Disponível em: <http://www.ibope.com/pt-br/noticias/paginas/numero-de-pessoas-com-acesso-ainternet-no-brasil-chega-a-105-milhoes.aspx>. Acesso em: 2 jan. 2014.

586 ALDÉ, Alessandra; BORGES, Juliano. Ataques na Internet nas eleições de 2002 (ou como os sites pautaram a cobertura da imprensa). In: ENCONTRO ANUAL DA ANPOCS, XXVIII. Seminário 
simpatizantes a participar de enquetes em sites e portais, e que atuavam também para rebater as críticas ao candidato publicadas em blogs e sites jornalísticos. Naquele ano, aproximadamente $13 \%$ dos brasileiros tinham acesso à Internet, ${ }^{588}$ ou seja, um número muito restrito e, por isso mesmo, o uso político da Internet se limitava à classe política, aos profissionais da comunicação e aos pesquisadores de maneira geral. A discussão política era primordialmente conduzida nos veículos habituais de rádio e televisão.

Em 2006, como já apontado, 25\% do eleitorado faziam uso da Internet, “[...] um universo composto majoritariamente de integrantes das classes A e B, [ressaltando que] o consumo de Internet não implica diminuição de consumo de outras mídias.”589 Os três principais blogs políticos brasileiros eram de Ricardo Noblat, Josias de Souza e Fernando Rodrigues, todos jornalistas vinculados a grandes jornais. Havia, assim, uma transferência da elite política off-line para o mundo on-line. Os blogs, de certa maneira, apenas reproduziam o que acontecia nas outras mídias, e a Internet ainda não possuía uma estratégia própria que promovesse o debate político, sendo mais uma peça do sistema de articulação de notícias.

Além dos blogs, o Orkut que, à época, era o site de comunidades da Internet mais popular no Brasil, foi igualmente empregado para manifestações políticas. Barros Filho, Coutinho e Safatle anotam que os candidatos Geraldo Alckmin (PSDB) e Lula (PT), os quais foram ao segundo turno, possuíam comunidades específicas no Orkut, a favor ou contra os candidatos, que reuniam mais de 1.531.000 integrantes, no dia 27 de

Temático 09 - “Democracia, comunicação política e eleições”. Anais... Caxambu, MG, 26 a 30/10/2004,. Para ser mais exata, a Internet havia sido usada nas eleições de 1998, mas o clima de vitória antecipada (Fernando Henrique Cardoso foi reeleito em primeiro turno, com cerca de 53\% dos votos válidos) fez com que essa plataforma tivesse pouca importância naquele pleito, para o qual havia sido autorizado o uso eleitoral da Internet, a partir do dia 5 de julho (art. 57, 57-A, 57-B, 57-C e 57-D da Lei $n^{\circ}$ 9.504/1997). Os candidatos ou qualquer pessoa podiam manter blogs, sites e páginas nas redes de relacionamento, como Orkut, Facebook e Twitter.

587 Ideia desenvolvida pelo gestor da campanha, Moriael Paiva, que comparava o site a uma operação de guerra: "Venha para o Pelotão 45, venha para a guerra". Paiva afirma que, em duas semanas, eles tinham 25 mil pessoas cadastradas e que eram acionadas para promover a campanha de Serra. Disponível em: <http://www.revistabrasileiros.com.br/2009/03/06/internet-o-futuro-daseleicoes/\#.UsrCGfRDvCs>. Acesso em: 4 ago. 2013.

588 Cálculos feitos pelo consultor e professor de pós-graduação da Fundação Getúlio Vargas, Marcelo Coutinho, para o IDG Now!, que fez o cruzamento de dados do TSE e do Comitê Gestor da Internet $\begin{array}{lllll}\text { para chegar ao } & \text { asultado. }\end{array}$ <http://www.nic.br/imprensa/clipping/2009/midia605.htm>. Acesso em: 29 jul. 2013. 
outubro de 2006, o equivalente a $1,5 \%$ do total de eleitores no segundo turno. ${ }^{590} \mathrm{~A}$ comunidade denominada “Geraldo Alckmin Presidente 45” era a maior da rede, entre os candidatos que disputavam o pleito, com 221 mil participantes, representando a $237^{\text {a }}$ comunidade na lista do Orkut. Portanto, apesar de um milhão e meio de pessoas terem acessado as diversas comunidades dessa rede social, esse número precisa ser contextualizado, porque ele era muito pulverizado entre os diversos grupos e não apresentava um diálogo político consistente:

Em relação à dinâmica dessas comunidades, um exame aleatório dos comentários postados mostrou que elas eram usadas mais como uma fonte de afirmação dos eleitores e declaração de voto do que como um “fórum de debates” para “esclarecer” o eleitorado. ${ }^{591}$

Assim, para esses analistas, durante essas eleições de 2006, as formas de manifestação existentes na Internet ainda não traziam vitalidade para a discussão política, nem atraíram eleitores excluídos do debate tradicional. ${ }^{592}$ Além disso, o baixo percentual de indivíduos ligados à Internet fez com que essa ferramenta fosse subestimada pelos candidatos. A internet era um espaço que servia à divulgação das agendas dos candidatos e para discursos e contradiscursos, muitas vezes ofensivos, oriundos das comunidades criadas pelos internautas.

Silveira, por outro lado, observa esses dados sob ângulo diverso, valorizandoos pela sua capacidade de estimular a comunicação. No entender do autor, o fato de as pessoas usarem a Internet e o Orkut para se expressar diariamente, durante o período eleitoral, e de permitir manifestações e respostas rápidas e instantâneas de seus participantes, quebra o sentimento de isolamento que as outras mídias de massa geram, representando um passo fundamental para a articulação política em grande escala:

590 O site do TSE informa que, nas eleições de 2006, havia cerca de 102 milhões de eleitores no segundo turno.

591 BARROS FILHO, Clóvis; COUTINHO, Maurício; SAFATLE, Vladimir. Op. cit., p.97.

592 A título de comparação, fornecemos os dados apresentados pela Pew Internet \& American Life Project sobre a campanha norte-americana, no ano de 2004, mostrando como a Internet já era valorizada no cenário político: “(1) 63 million online political news consumers used the Internet for political information, (2) 43 million discussed politics via e-mail, and (3) 13 million used the Internet to make campaign contributions or arrangements for volunteer efforts.[...] Furthermore, more than half the online news consumers (52\%) indicated that information from the Internet helped in their vote decision making." WILLIAMS, Andrew P.; TEDESCO, John C. The internet election: perspectives on the web in campaign 2004. Oxford: Rowman \& Littlefield, 2006, p. 1. 
É possível afirmar, sem exagero, que nunca cidadãos comuns escreveram tanto sobre política como no ano de 2006. A Internet deu sentido à escrita política. Escreveu-se para criticar ou para defender um candidato, mas também para interpretar os fatos que estavam acontecendo. [...] Também dei força a uma modalidade até então marginal de texto político, o desabafo. Pessoas expunham sua indignação em listas, blogs de pouca audiência e em milhares de mensagens enviadas pelo Orkut. ${ }^{593}$

Para Silveira, pois, a simples existência da comunicação descentralizada e interativa que ocorre na rede, ao dar espaço para tantas vozes, já pode ser compreendida como um ganho para o debate político.

Malgrado a profunda reflexão apresentada por Silveira, concordamos apenas parcialmente com sua posição. A multiplicidade de fontes, a possibilidade de veiculação de mensagens provenientes de todos os cantos do país, a interatividade, a facilidade de publicação, a disseminação de informações de forma simples e rápida, todos esses fatores contribuem para a viabilização do papel do cidadão como um ator mais ativo, o que é de fundamental importância para o fortalecimento da democracia e cidadania. Contudo, a democracia é um espaço de formação de consensos e dissensos, o que exige um debate pluralista, com repúdio à intolerância. Para tanto, não basta a manifestação da ideia; é preciso que as pessoas se escutem umas às outras, reflitam sobre conceitos opostos, na busca da convergência do ideal do bem comum. A Internet tem favorecido a ampla manifestação, mas os cidadãos ainda precisam aprender a ouvir uns aos outros nesse ambiente, pois só assim será possível efetivar um rico debate político sobre a sociedade e o Estado. A comunicação política é, sem dúvida, fundamental, porque ela constrói cenários de representação da realidade pública e, a partir disso, é capaz de redefinir a própria natureza da política. Todavia, ela implica transmissão e recepção de mensagens. Só assim ela se torna um instrumento de difusão das visões de mundo e dos projetos políticos. $^{594}$

593 SILVEIRA, Sérgio Amadeu de. Combates na fronteira eletrônica: a Internet nas eleições de 2006. In: In: LIMA, Venício Artur de. A mídia nas eleições 2006. São Paulo: Fundação Perseu Abramo, 2007, p. 181.

594 MIGUEL, Luis Felipe. Os meios de comunicação e a prática política. Lua Nova, São Paulo, n. 55-56, pp. 155-184, 2002. 
Nas eleições municipais de 2008, conduzidas na cidade de São Paulo, os três principais candidatos em disputa eram Geraldo Alckmin, Gilberto Kassab e Marta Suplicy, eleições disputadas em dois turnos e vencidas por Kassab.

A pesquisa Ibope Inteligência apontou que o meio de informação mais utilizado para obter informações sobre esse pleito era a televisão, de preferência de $55 \%$ dos entrevistados, seguido pelo jornal, que foi a opção de escolha de $10 \%$ dos participantes da pesquisa. Apenas $5 \%$ dos entrevistados mantinham-se atualizados pela Internet. $^{595}$

Esse resultado do emprego da Internet nas eleições é maior do que os resultados nacionais, em que apenas $2 \%$ dos entrevistados afirmaram acessar a rede mundial para obter informações sobre o pleito.

Tanto em São Paulo como no restante do país, as pesquisas afirmam que aqueles com maior escolaridade e maior renda fazem maior uso da Internet.

No ano de 2008, o Orkut continuava sendo uma importante rede social no país. Geraldo Alckmin, que já possuía várias comunidades, nas eleições presidenciais de 2006, pôde utilizá-las na campanha de 2008, tendo aproveitado “[...] mais de 85 mil integrantes da sua comunidade na campanha para Presidente para fazerem parte da comunidade voltada para a eleição de prefeito.” ${ }^{596}$ Com isso, pode-se afirmar que a Internet representa um mecanismo de mobilização que perdura ao longo do tempo.

A pesquisa conduzida por Coutinho e Safatle sobre as eleições em 2008 identificou um problema ainda recorrente na Internet e que eles chamaram de "[...] baixa permeabilidade a visões contrárias”. ${ }^{597}$ Cass Sustein já chamou a atenção para esse aspecto negativo da rede, em sua obra Republic.com 2.0.

\footnotetext{
595 Disponível em: <http://www.eleicoes.ibope.com.br/Paginas/Home.aspx>. Acesso em: 21 dez. 2012.

596 COUTINHO, Marcelo; SAFATLE, Vladimir. A Internet e s eleições municipais em 2008: o uso dos sítios eletrônicos de comunidades na eleição paulistana. Revista de Sociologia e Política, Curitiba, vol. 17, n. 34, out. 2009.

597 COUTINHO, Marcelo; SAFATLE, Vladimir. Op. cit.
} 
Sustein analisa o desenvolvimento da Internet e seus desdobramentos, no que diz respeito ao constitucionalismo contemporâneo. Sua análise está centrada no fato de que as pessoas têm estado cada vez mais expostas a diversos tipos de informação que elas, provavelmente, não teriam escolhido anteriormente. O desafio da sociedade globalizada mostra-se em saber avaliar como as novas tecnologias afetam a cidadania nas suas dimensões civil, política e social, e não apenas o cidadão-consumidor, habituado efetivamente a escolhas subjetivas e individuais. Para o professor, esse problema precisa ser enfrentado com urgência, pois, da forma que se apresenta, com a liberdade de expressão tendo sua importância vinculada à soberania do consumidor, a democracia perde um importante instrumento para seu revigoramento. ${ }^{598}$

Sunstein alerta para a formação de câmaras isoladas, nas quais estão inseridos os indivíduos a ouvir apenas o eco de suas próprias vozes. Esses indivíduos não conseguem ouvir o que dizem os outros cidadãos, ou os vê como inimigos, o que, obviamente, impossibilita o cultivo do debate democrático. ${ }^{599}$

O autor toma o exemplo dos fóruns públicos da antiguidade, nos quais existia reflexão e debate entre os vários pontos de vista heterogêneos, mas que, na Internet, apesar da existência de tantos espaços de discussão, o que se constata é a propensão das pessoas a navegar em sites cujo recorte é sempre o mesmo, formando pequenos grupos que possuem as mesmas opiniões. Para o autor, a junção de pessoas que pensam da mesma maneira transforma esses espaços em "echo-chambers", com a ausência de debate e apenas a reafirmação constante do que eles mesmos pensam e acreditam, o que radicalizaria ainda mais suas posições, pela falta de conhecimento de opiniões divergentes.

Sunstein não é um pessimista em relação à Internet. Ele apenas constata que essa ferramenta apresenta benefícios, mas também dificuldades, as quais podem ser superadas com o fomento compromissado dos valores democráticos e republicanos.

\footnotetext{
598 SUSTEIN, Cass. Republic.com 2.0. Princeton: Princeton University Press, 2007, p. 135-163.

599 "In a democracy, people do not live in echo chambers or information cocoons.[...] Members of a democratic public will not do well if they are unable to appreciate the views of their fellow citizens, or if they see one another as enemies or adversaries in some kind of war.” SUSTEIN, Cass. Op. cit., p. XI.
} 
Retomando o artigo de Coutinho e Safatle, eles se depararam com uma situação muito próxima à levantada por Sunstein:

As 25 comunidades analisadas apresentavam links para outras 78 comunidades político-eleitorais. Desse total, apenas 11 eram de comunidades "neutras", ou seja, que tratavam de política em geral. E nenhuma apontou links para outras comunidades que apresentassem visões diferentes sobre os candidatos. Ou seja, as comunidades tendem a apresentar uma "permeabilidade" muito baixa em relação a visões políticas contrárias. ${ }^{600}$

A conclusão à qual eles chegam, tendo em vista a pesquisa anterior das eleições de 2006, é que houve um crescimento na utilização da rede para a abordagem de questões políticas, reforçando sua característica de espaço complementar às mídias tradicionais, mas que ainda carece de um debate entre opiniões contrárias, que são rechaçadas agressivamente. Apesar disso, Coutinho e Safatle são otimistas em relação às potencialidades da Internet para o debate político, salientando que, ao longo do tempo, as redes sociais serão capazes de “[...] produzir movimentos significativos na opinião pública, ao ponto de pressionar os agentes políticos ou mesmo [...] influir nos resultados eleitorais.”601

Nas eleições 2010, o uso da Internet e suas mídias foi ainda mais intenso.

O PT possuía o site do partido - www.pt.org.br - no qual havia uma chamada para o site "Dilmanaweb.com.br", o blog oficial da candidata. O internauta era convidado a ser um “petista 2.0”, devendo fazer seu cadastro para participar da rede de militantes on-line do PT. No final do formulário de cadastro, havia um campo que dizia: “Autorizo a utilizar meus dados pessoais de acordo com o Termo de Uso”, termo este que, infelizmente, não foi encontrado em nenhum lugar do site. Havia, ainda, um link para a TV PT, que apresentava vários vídeos de campanha e ações desenvolvidas pelo partido. Por fim, na seção “Eleições 2010”, havia diversas notícias sobre o pleito.

600 COUTINHO, Marcelo; SAFATLE, Vladimir. Op. cit. Sánchez Agesta, no mesmo sentido, asseverava em sua obra, escrita em 1976, que "[e]l elector escucha la propaganda de las opiniones que ya ha aceptado. La formación de juicios y actitudes es un proceso lento, consecuencia de muy diversos factores.” SÁNCHEZ AGESTA, Luiz. Op.cit., p. 276.

601 COUTINHO, Marcelo; SAFATLE, Vladimir. Op. cit. 
Já no site www.Dilmanaweb.com.br, além de fazer o cadastro, o internauta podia contar a sua história, isto é, ele era convidado a mostrar como foi afetado pelas mudanças havidas no país, durante os últimos anos de governo petista. No entanto, não se sabe o que foi feito com essas informações.

A campanha petista estava igualmente no YouTube. O canal "Dilma na web" tinha poucos vídeos cadastrados e comentários favoráveis ou contrários à campanha.

O perfil de Dilma, no Facebook, era pouco explorado, com poucas fotos e sem indicação de comunidades oficiais da candidata. O Twitter de Dilma contava com cerca de 35 mil seguidores.

Nota-se, pois, maior preocupação da campanha com a Internet e as mídias sociais. Percebe-se que foi desenvolvida uma estratégia para a Internet, que buscava o cadastro dos internautas, fornecia dados da campanha, exibia fotos e vídeos, ou seja, havia uma intenção em envolver e aproximar o usuário. A despeito do diálogo e interação ainda precários, há uma evolução em relação às eleições anteriores, na tentativa de atrair eleitores por todos os meios à disposição. Destaque para o site petista que tinha uma chamada direcionada aos eleitores entre 16 e 18 anos, incentivando-os a votar nas próximas eleições. Como essa faixa etária da população é uma das mais ativas na Internet, foi uma opção razoável.

O PSDB, da mesma maneira, tinha site próprio - www.psdb.org.br - com notícias das eleições sem, todavia, haver a possibilidade de deixar comentários. O site também dava acesso à TV Tucana e à Rádio Tucana, bem como aos links denominados “Diário Tucano”, “Ninho Tucano”, “Petrobras Blog da CPI” e "Blog do PSDB de Minas Gerais”.

O "Petrobras Blog Tucano" era um espaço que promovia o debate entre simpatizantes do partido e seus líderes, mas exigia cadastramento prévio. E, no "Diário Tucano" havia um link para o site www.mobilizapsdb.org.br, cujo intento era mobilizar pessoas a favor da candidatura José Serra, convidando os usuários para ações do partido, possibilitando o download de material de campanha, como banners. Esse site, 
por ter o formato de um blog, permitia ao internauta deixar opiniões e sugestões e enviar as notícias para pessoas de seu conhecimento.

Foi elaborado ainda o site www.amigosdoserra.com.br, no qual o internauta podia mandar recados ao candidato, além de conter várias entrevistas, reportagens e textos de Serra, em variados veículos da mídia. As notícias podiam ser compartilhadas no Twitter e Facebook, podiam receber comentários e ser enviadas para outras pessoas.

No YouTube, havia o canal “Amigos do Serra”, com mais de 200 vídeos publicados.

José Serra possui conta no Twitter desde 2009, com mais de um milhão de seguidores, no qual o político interage enviando links e respondendo a seus seguidores. Essa mídia foi bem utilizada pelo candidato, nas eleições de 2010, especialmente no diálogo com os cidadãos, uma prova de que é possível estabelecer uma relação direta e estreita entre eleitores e candidatos.

O site do PSDB era confuso e nada convidativo, porque a navegação era complicada, e seguir os links e informações dadas não era muito fácil. ${ }^{602}$ Atuação melhor teve o site Mobiliza PSDB, com orientações claras para quem deseja se engajar e exemplos de mobilização na Internet, a qual estimulava a elaboração de outras ações semelhantes. Os encontros eram realizados on-line com vídeos transmitidos ao vivo e chats em tempo real conduzidos entre os participantes, em mais um exemplo de aproximação e diálogo com o cidadão.

Conclui-se, assim, que houve um substancial incremento do uso da Internet nas eleições de 2010. As mídias sociais, sites e blogs foram elaborados de forma cuidadosa, o que denota a preocupação dos idealizadores das campanhas dos candidatos com esse veículo. O IBOPE Nielsen Online confirmou que havia 73,7 milhões de brasileiros com

\footnotetext{
${ }^{602}$ Para atrair a atenção dos internautas e fazer com que eles permaneçam na página visitada, é fundamental que a informação transmitida seja simples, direta e precisa. Experiência feita na Internet por Arthur Lupia e Tasha Philpot, em 2002, contou com 12 mil participantes acessando nove sites diferentes de notícias e informação política: "Their experiments indicated that when individuals perceived a site to be effective (to provide information faster, easier, and more accurately), that site was more likely to generate greater interest and an increased probability of participation." MOSSBERGER, K.; TOLBERT, C.; McNEAL, R. Digital citizenship: the Internet, society, and participation. Cambridge: MIT Press, 2007, p. 76.
} 
acesso à Internet em qualquer ambiente, ${ }^{603}$ número que não pode ser desprezado em uma campanha eleitoral.

Trabalho de pesquisa de Braga, Nicolás e Becher constatou, ainda, que “[...] do total de 406 candidatos ao Senado e aos governos estaduais nas 27 unidades da federação brasileira, 281 (69,2\%) deles usaram websites como ferramenta de campanha.”604

As eleições municipais de 2012, em São Paulo, foram marcadas por várias mudanças durante a corrida eleitoral. Inicialmente, havia quatro candidatos na disputa: Fernando Haddad (PT), José Serra (PSDB), Celso Russomano (PRB) e Gabriel Chalita (PMDB). A liderança, a princípio, era de Serra, depois esteve com Russomano, mas Chalita e Haddad não estavam fora da disputa. Em 4 de outubro de 2012, os jornais anunciavam que Haddad tinha 19\% da intenção de voto, Serra estava com 23\% e Russomano com 25\%, ${ }^{605}$ todos com chances de estar no segundo turno, que levou Serra e Haddad para a decisão, com a vitória do candidato petista.

A acirrada disputa, mesmo ocorrida em um curto espaço de três meses, chama a atenção para as campanhas eleitorais, as quais precisam ser cada vez mais assertivas, valendo-se de todos os meios para conquistar o eleitor. A Internet e suas mídias foram parte desse cenário político, sendo que o Facebook recebeu atenção especial dos candidatos.

O Facebook já alcançou a marca de 1 bilhão de usuários no mundo e tem no Brasil um de seus maiores celeiros, com mais 70 milhões de usuários ativos. ${ }^{606}$ É uma ferramenta que oferece diversas possibilidades de interação, diálogo em tempo real,

603 Disponível em: <http://www.ibope.com/pt-br/relacionamento/imprensa/releases/Paginas/Acesso\%C3\%A0-internet-no-Brasil-chega-a-83,4-milh\%C3\%B5es-de-pessoas.aspx>. Acesso em: 29 ago. 2012.

604 BRAGA, Sérgio; NICOLÁs, Maria A.; BECHER, André R. Elites políticas e NTICS: uma análise do uso da Internet pelos candidatos aos governos estaduais e ao senado federal nas eleições brasileiras de outubro $\quad 2010.2$ de 2 em: $<$ http://www.anpocs.org.br/portal/35_encontro_gt/GT01/Nicolas_Becher_Braga.pdf $>$. Acesso em: 2 set. 2013.

605 Pesquisa DATAFOLHA. Disponível em: <http://datafolha.uol.com.br.>. Acesso em: 4 out. 2012.

${ }^{606}$ Em setembro de 2013 o Brasil contava com 76 milhões de usuários. Disponível em: $<$ http://g1.globo.com/tecnologia/noticia/2013/09/brasil-e-o-2-pais-com-mais-usuarios-que-entramdiariamente-no-facebook.html>. Acesso em: 21 dez. 2013. 
compartilhamento de fotos e arquivos. Mas vinha sendo usada nas últimas eleições como um painel de fotos virtual do candidato, diante da incapacidade ou desinteresse dos organizadores de campanha de aprofundar seu uso durante o pleito. O cenário sofre alteração nas eleições em tela.

José Serra usou sua página para dar continuidade às mobilizações lançadas na campanha de 2010, que tiveram boa receptividade dos cidadãos. Chalita, da mesma forma, priorizou a mobilização, direcionando mais da metade das postagens para atrair os eleitores para os encontros programados em sua agenda.

O Facebook de Haddad foi mais equilibrado, enfocando debates políticos, mobilização de cidadãos e divulgação de sua agenda, além de destacar as figuras do expresidente Lula e da presidente Dilma Roussef.

Russomano, por fim, praticamente expunha sua agenda e postava acesso aos vídeos de seu programa.

Por conseguinte, o primeiro turno das campanhas foi marcado pelo uso do Facebook, que privilegiava a interação, e a compreensão do valor desse elemento nas campanhas eleitorais tem sido cada vez maior. Ainda não pode ser comparado ao modelo estadunidense de 2008, mas apresenta uma grande diferença das eleições do ano de 2006. A lógica das campanhas brasileiras quanto ao uso da Internet ainda segue um modelo top-down, ou seja, o controle do conteúdo e da ação ainda está nas mãos do partido e da equipe de campanha, e ainda há muito a ser feito para a inversão desse modelo. Todavia, o fato de as campanhas eleitorais na Internet ganharem gradativa relevância revela a percepção dos representantes e partidos de que o diálogo direto com os representados tem sido uma exigência do demos e, portanto, acreditamos que esse espaço virtual será cada vez mais valorizado, no processo eleitoral.

Afinal, a Internet e suas mídias e plataformas oferecem grandes vantagens, permitindo a realização de reuniões entre líderes nacionais e regionais, agilizando o envio do material de campanha, barateando custos, além de poder saber diretamente do cidadão se as campanhas e propostas feitas vão ao encontro de seus interesses. 
É evidente que a mera existência da rede de computadores não provocará maior engajamento político. É preciso que as potencialidades da rede sejam exploradas para a promoção do diálogo e da troca de ideias.

Os partidos têm adotado a Internet como uma ferramenta a complementar as mídias tradicionais, as quais não serão substituídas, por enquanto, mas terão que cada vez mais estreitar esse convívio. Os cidadãos ainda consideram as mídias tradicionais como sua fonte principal de informação. Conforme o Pew Internet Center, mais de 90\% das notícias discutidas na mídia social são cópia de matérias veiculadas nos formatos digitais dos meios tradicionais. ${ }^{607}$ Por outro lado, os sites de relacionamentos e blogs possibilitam que as agendas sejam definidas e difundidas pelos próprios cidadãos e não por conglomerados midiáticos, o que confere legitimidade ao processo político.

A possibilidade de atuação on-line faz com que o indivíduo se transforme em um formador de opinião. Ele pode deixar de lado uma atitude passiva e se expressar, trocar ideias, sentir-se parte do debate político, sentir que pode exercer influência sobre outras pessoas com seus conhecimentos. Isso valoriza o indivíduo, servindo de incentivo para novas ingerências na web.

Braga, França e Nicolás focalizam, com base em esquema de análise desenvolvido por Gibson e Ward, cinco formas pelas quais a Internet pode ampliar a comunicação dos partidos políticos face às mídias tradicionais:

[...] aumento do volume da comunicação; aumento da velocidade da comunicação; aumento das possibilidades do formato da apresentação; a direção da comunicação é ampliada em vários sentidos, lateral, horizontal e verticalmente e, por fim, o controle da comunicação é descentralizado, ampliando as possibilidades de controle dos indivíduos sobre os fluxos de comunicação e colocando-os numa posição mais ativa. ${ }^{608}$

607 Disponível em: <http://anj.org.br/sala-de-imprensa/noticias/a-maioria-das-reprotagens-originaisvem-da-imprensa-tradicional>. Acesso em: 06 nov. 2013.

608 BRAGA, Sérgio Soares; FRANÇA, Andressa S. T.; NICOLÁS, Maria Alejandra. Os partidos políticos e a Internet - uma avaliação dos websites dos partidos políticos do Brasil. Revista de Sociologia e Política, Curitiba, v. 17, nº 34, p. 187, out. 2009. 
Demais disso, no Brasil, país em que se constata alto nível de personalização das campanhas, poder mostrar o candidato como uma pessoa comum, que se comunica pela Internet como qualquer outro, parece ser uma tática cada vez mais assertiva.

Outra curiosidade da rede é que ela provoca mobilizações, que tanto podem ser restritas ao ambiente virtual como concretizadas por encontros físicos, antecedidos de convites virtuais. Para os partidos e políticos, isso propicia níveis diferenciados de engajamento, que podem ser úteis às estratégias de campanha política, por oferecer opções variadas de participação.

É fato que o acesso à Internet ainda é menor do que o acesso aos aparelhos de televisão. Todavia, a propaganda eleitoral televisiva interrompe a programação normal, força o indivíduo a ter acesso àqueles personagens que entram em suas casas, muitas vezes, sem terem sido convidados. Em consequência, muitos cidadãos reclamam do horário eleitoral. Por outro lado, acessar a página da Internet e acompanhar as notícias políticas depende do interesse e da disponibilidade de tempo do cidadão. É uma atitude mais democrática e palatável, que tende a crescer com o tempo.

O eleitor está atento ao movimento que ocorre na Internet. Em janeiro de 2013, Dilma retomou seu perfil no Twitter, inativo desde o final da campanha de $2010 .{ }^{609} \mathrm{~A}$ presidente havia sido criticada por internautas por ficar ausente do micro-blogging por tanto tempo e, com as novas eleições à vista, tratou de voltar à rede. Os políticos devem manter presença constante nas mídias sociais e blogs, não fazer deles um uso pontual e eleitoreiro, pois isso provoca um novo distanciamento por parte do eleitor, que quer se sentir importante para o processo político e respeitado pelo representante a todo o momento, não apenas no período eleitoral.

O cenário brasileiro favorece a relação entre Internet, eleição e processo eleitoral. O número de internautas aumenta anualmente, abrangendo classes sociais diversas. Se o perfil do internauta brasileiro ainda é o de classe mais alta, com maior escolaridade, a ampliação do acesso à rede pode provocar uma mudança de perfil em breve. No Rio de Janeiro, por exemplo, 90\% dos jovens de cinco áreas de baixa renda

609 Disponível em: <http://www1.folha.uol.com.br/fsp/tec/133742-no-twitter-dilma-e-bolada-falam-emredes-separadas.shtml>. Acesso em: 26 set. 2013. 
(Cidade de Deus, Complexo do Alemão, Complexo da Penha, Manguinhos, Rocinha) acessam a Internet, priorizando redes sociais como o Facebook, e a maioria utiliza o computador de sua própria casa. ${ }^{610} \mathrm{~A}$ partir do momento em que eles decidirem participar dos sites e fóruns de debates governamentais, ou perceberem as várias opções de controle das políticas públicas oferecidas pelas sociedades civis que atuam na rede, muito terá que ser mudado nas campanhas eleitorais.

Além disso, a banda larga está presente em 40\% das casas do país, e o governo pretende expandir esse número para 70\%, até o final de $2014 .{ }^{611} \mathrm{~A}$ facilidade de acesso à rede será um grande estímulo para que as pessoas acessem o mundo virtual e permaneçam mais tempo nele, buscando e trocando informações, inclusive as de cunho político.

Não se pode esquecer, igualmente, o aumento do número de celulares com Internet. Conforme os fabricantes mundiais de celulares e smartphones, há uma classe de menor renda que quer se manter conectada à Internet. Lançamentos de modelos mais baratos têm movimentado o mercado.

A fragmentação do acesso à Internet é um problema sério a ser debatido com rigor, na busca de medidas que consigam promover o encontro de diferentes visões de mundo. Esse é um grande entrave ao uso da Internet no fortalecimento da cidadania, porém, é um processo que pode ser revertido. A própria ampliação do uso da Internet como uma ágora virtual cada vez mais ampliada pode provocar o encontro de múltiplas vozes desconhecidas, mas abertas a essa dinâmica interativa da Internet.

A grande vantagem da Internet é ser uma plataforma participativa e interativa, que pode aproveitar a inteligência coletiva e promover uma ética da cooperação. Ao facilitar a organização de um ativismo on-line e proporcionar aos cidadãos distintas atividades que se adequem aos seus interesses, a própria Internet será capaz de estimular um comportamento com perfil mais agregador.

\footnotetext{
610 Disponível em: <http://www1.folha.uol.com.br/cotidiano/1231878-morador-de-favela-esta-superligado-a-internet-diz-pesquisa.shtml>. Acesso em: 17 nov. 2013.

611 Disponível em: <http://www1.folha.uol.com.br/fsp/mercado/45406-banda-larga-chega-a-40-dascasas-do-pais.shtml>. Acesso em: 28 maio 2012.
} 
A democracia precisa ser entendida não só como um simples ato de escolha de representantes, mas como um conjunto de ações, valores e atitudes que explorem da melhor forma as ferramentas de comunicação contemporânea.

\subsection{Legislação específica e o Twitter na visão do TSE: novos debates e posicionamentos}

A Constituição Federal completou, no ano de 2013, seus 25 anos, e recebeu justas homenagens, várias análises e estudos. Todos lembraram que o debate sobre a Constituição realizado durante a reunião da Assembleia Constituinte era amplo e plural, tendo contado com intensa participação popular.

Em seguida, esse debate ficou um tanto quanto restrito ao meio acadêmico e aos profissionais do Direito, que estabeleciam seus conceitos e traçavam as linhas interpretativas que formariam a conjuntura da nova sociedade democrática brasileira.

Nos últimos anos, entretanto, a Constituição recobrou o engajamento público, ao se firmar como um marco de referência para os direitos civis, sociais e eleitorais, para a atuação da imprensa e para os movimentos sociais que lutam pelos direitos elencados na Constituição. Assim, a Constituição voltou a ganhar importância, ao atuar pelo fortalecimento das instituições e pela consolidação da sociedade democrática nela prevista.

O Direito deve ser constantemente atualizado, para oferecer respostas dinâmicas à sociedade. Saber lidar com as novas situações trazidas pela Internet criou a necessidade de se conciliar a ciência do Direito com as novas tecnologias, que promoveram mudanças substanciais, rápidas e intensas na sociedade contemporânea, ampliando a comunicação e compartilhando ideias que demandam maior transparência e liberdade de expressão. A facilitação do acesso à Internet deve ser vista como uma maneira de estender a cultura política, ampliar a cidadania, e aprofundar a democracia, garantindo a concretização dos direitos previstos constitucionalmente. 
A igualdade e a liberdade postas na Constituição não podem continuar sendo apenas promessas. Nesse sentido, segue breve análise da Lei de acesso à informação, Marco civil da Internet e do recente julgamento conduzido pelo TSE sobre o uso do Twitter, nas eleições, por representarem abordagens do direito sobre o universo digital que contribuem para a elaboração de uma concepção forte de democracia.

\subsubsection{Lei de acesso à informação (LAI)}

A lei $n^{0} 12.527$ - Lei de Acesso à Informação - foi promulgada em novembro de 2011 e entrou em vigor em 16 de maio de 2012, dispondo sobre os “[...] procedimentos a serem observados pela União, Estados, Distrito Federal e Municípios, com o fim de garantir o acesso a informações previsto no inciso XXXIII do art. $5^{\circ}$, no inciso II do $\S 3^{\circ}$ do art. 37 e no $\S 2^{\circ}$ do art. 216 da Constituição Federal.”“12

$\mathrm{O}$ art. $5^{\circ}$, XXXIII, da $\mathrm{CF} / 88$ se refere ao direito que todos possuem de ter acesso a informações de seu interesse particular, interesse coletivo ou geral, as quais estão em posse dos órgãos públicos. Já o art. $37, \S 2^{\circ}$ da CF/88 estabelece que o acesso a registros administrativos e a informações sobre atos de governo pelos usuários será disciplinado por lei, enquanto o art. 216, $\S 2^{\circ}$, da CF/88 define que a administração governamental fica responsável pela gestão da documentação relativa ao governo e deve tomar as providências para permitir a consulta pelos cidadãos.

A LAI veio para regulamentar esse direito à informação, garantido constitucionalmente, obrigando os órgãos públicos a considerar a publicidade a regra, e o sigilo a exceção.

Ora, tanto o cidadão deve explicação ao Poder Público como o Poder Público deve explicação ao cidadão. Do contrário, irrompe a desordem na primeira situação, ou a arbitrariedade, na segunda. A LAI aponta os procedimentos de divulgação de informações de interesse público e facilita o acesso a esses dados, inclusive com o uso da tecnologia da informação. Seu espírito é fomentar a transparência e apurar o controle social sobre a administração pública.

612 BRASIL. Lei $n^{\circ} 12.527$, de 18/11/2011, art. $1^{\circ}$. 
União, Estados, Distrito Federal e Municípios estão sujeitos à LAI, bem como os Tribunais de Contas, autarquias, fundações públicas, sociedades de economia mista e entidades privadas sem fins lucrativos que recebam recursos públicos, nos termos do art. $1^{\circ}$, parágrafo único, incisos I e II, e art. $2^{\circ}$ da Lei.

Seu art. $4^{\circ}$ indica o que é informação pública, que inclui aquela produzida ou acumulada por órgãos e entidades públicas, ou aquela elaborada ou mantida por pessoa física ou privada decorrente de um vínculo com órgãos e entidades públicas. Informação sobre atividades de órgãos e entidades que abranjam sua política, organização e serviços, bem como informações relativas ao patrimônio público, utilização de recursos públicos, licitação e contratos administrativos fazem igualmente parte dessa definição, que ainda atinge as informações sobre políticas públicas, inspeções, auditorias, prestações e tomadas de contas.

Em se tratando de alguma dessas hipóteses, os órgãos públicos são obrigados a facilitar a divulgação das informações, seja através de um serviço em local apropriado que atenda o cidadão, seja pelo estímulo à participação popular em audiências e consultas públicas.

Além disso, os sites dos órgãos abrangidos pela LAI devem oferecer ferramentas que tornem o acesso a essas informações fáceis e simples de ser entendido e manipulado (art. $8^{\circ}$, $\S 2^{\circ}$ e $\S 3^{\circ}$ da lei em foco), o que faz da Internet um espaço privilegiado para o cumprimento dessa lei.

O Estado é uma área meio, não fim, por isso a sociedade deve ter acesso a informações sobre os cargos públicos, salários e benefícios, além de exercer o controle sobre esses custos. Rotineiramente, os órgãos devem divulgar suas competências, dados para contato dos funcionários, suas despesas e outras informações gerais sobre seus procedimentos, mantendo sempre uma estrutura de atendimento ao público, seja física, seja virtual. O site eletrônico facilita o conhecimento das instituições e é um grande incentivo à transparência e à prestação de contas governamentais, posto que qualquer cidadão com o mínimo de conhecimento sobre Internet pode ter acesso às amplas políticas administrativas e de gerenciamento de recursos humanos que norteiam os órgãos do Estado. 
Para que a LAI se torne um relevante instrumento democrático, todavia, é preciso que o Estado disponibilize as informações públicas.

Polêmica surgiu logo após a entrada em vigor da lei em relação à divulgação da remuneração dos servidores públicos pela Internet. As justificativas para a falta dessa publicação foram várias, como a dificuldade de manter o processamento dos dados atualizados, ou uma interpretação restritiva da lei, que entendia que os nomes dos funcionários não precisavam ser divulgados, bastava apresentar o valor da remuneração. Ainda argumentaram que o conhecimento sobre quanto ganhava cada servidor era um atrativo aos criminosos, que se aproveitariam disso para definir roubos e sequestros, ou que essa obrigatoriedade estaria ferindo o direito à intimidade e à privacidade.

Coube ao STF pronunciar-se sobre o caso, na ação ordinária 1.823, de relatoria do Ministro Luiz Fux.

Na origem, foi impetrado mandado de segurança pelos servidores do Tribunal de Justiça de Minas Gerais contra ato do presidente do TJ mineiro que, baseando-se na resolução 151/2012 do CNJ, determinou a divulgação completa do nome do servidor e de sua correspondente remuneração. Por envolver aplicação de resolução do $\mathrm{CNJ}^{613}$, a causa chegou ao STF, o qual entendeu que o cidadão que ingressa no serviço público adere ao regime jurídico próprio da Administração Pública, no qual está prevista publicidade de todas as informações relevantes para a coletividade, como a remuneração dos servidores, ficando assentado que a remuneração é informação de interesse geral e deve ser divulgada. Assim:

AÇÃO ORIGINÁRIA. RESOLUÇÃO 151/2012 DO CONSELHO NACIONAL DE JUSTIÇA. ALEGAÇÃO DE VIOLAÇÃO DOS DIREITOS À INTIMIDADE, À PRIVACIDADE E À SEGURANÇA. IMPROCEDÊNCIA. OBSERVÂNCIA AOS PRINCÍPIOS DA PUBLICIDADE E DA TRANSPARÊNCIA QUE NORTEIAM A ATIVIDADE ADMINISTRATIVA, BEM COMO AO DIREITO FUNDAMENTAL DE ACESSO À INFORMAÇÃO. PEDIDO A QUE SE NEGA SEGUIMENTO. ${ }^{614}$

613 Conforme previsto pelo art. 102. I, “r”, da CF/88.

614 BRASIL. STF. AO 1823 MG - Relatoria do Min. Luiz Fux. Julgamento em 14/10/2013, publicado em 17/10/2013. 
Com isso, ficou pacificada a questão e desde então se pode saber quanto recebem os servidores públicos, ${ }^{615}$ estando os dados à disposição na Internet.

Publicidade e transparência são características de um governo democrático. O cidadão tem o direito de conhecer os custos da máquina estatal, para onde vai o dinheiro público, se há privilégios ou não. Desse modo, foi correta a decisão do STF. Agora, além da disponibilidade dos dados, é a sociedade civil que precisa ser atuante, fazendo efetivo uso dessa lei e de seus mecanismos. A lei só ganhará vitalidade se for integralmente colocada em prática pela sociedade, que precisa incorporá-la como uma conquista democrática. ${ }^{616}$ Afinal, democratizar é também ampliar as fontes de informação a que o cidadão pode recorrer.

Ainda cabe um comentário en passant sobre a LAI, no que concerne às informações que podem ser mantidas em sigilo e que foram diferenciadas em três níveis: ultrassecreto, secreto e reservado, aos quais se aplicam sigilo de 25, 15 e 5 anos, respectivamente, tornando-se a informação pública depois desses períodos. Assim, informações que põem em risco a defesa e a soberania nacionais, comprometem atividades de inteligência, prejudicam o desenvolvimento científico ou tecnológico, ou afetam a condução de negociações ou relações internacionais do país, dentre outras situações elencadas no art. 23 da lei, são tidas como imprescindíveis à manutenção da segurança do Estado e da sociedade, mantendo-se sob uma censura com prazo determinado.

Esse é um assunto definitivamente muito complicado e que merece debate atento, ao longo de outra tese ou dissertação, porém, precisa ser enfrentado com urgência, principalmente depois das revelações de espionagem pelos Estados Unidos, os

615 Em São Paulo, basta acessar o Portal da Transparência, disponível em: $<$ http://www.transparencia.sp.gov.br/explicativa.html>. Acesso em: 29 dez. 2013. Nesse portal, encontram-se informações sobre os dados disponibilizados e como são feitos os cálculos da remuneração. No portal da transparência do Estado de Pernambuco, por exemplo, para cada servidor é feito um relatório de remuneração, que indica nome, categoria, cargo, vencimentos, gratificações e descontos, dentre dados. Disponível em: <http://www2.transparencia.pe.gov.br/arquivos/remuneracao.html>. Acesso em: 29 dez. 2013.

616 Nesse sentido, são as manifestações de importantes organizações da sociedade civil, como as ONGs Artigo 19, Movimento Contra a Corrupção Eleitoral, Movimento Voto Consciente, Instituo Ethos, as quais atuam para promover maior participação e inserção social. 
quais não só recorrem a empresas como Microsoft, Yahoo, Google e Facebook ${ }^{617}$ para a prática desse ato, como ultrapassam suas fronteiras geográficas, afetando a soberania de outros países, como o Brasil, ${ }^{618}$ alegando que o que estava em jogo era a defesa nacional norte-americana. Desde o vazamento de informações do WikiLeaks, ${ }^{619}$ das denúncias de Edward Snowden ${ }^{620}$ ou, sobretudo, desde os ataques terroristas de 11 de setembro, os Estados Unidos têm acessado a comunicação de cidadãos e estrangeiros, sem haver o menor controle judicial, e praticado a espionagem, em uma inversão de valores primordiais para a democracia norte-americana, atingindo, dentre outras, a liberdade de expressão na Internet. Muitos dos debates giram em torno de publicidade e transparência, tentando justificar esses atos com afirmações de que um governo aberto não significa um governo absolutamente transparente, ou que todas as liberdades precisam de algum tipo de regulação, às vezes mais rígidas do que outras, e que, em acréscimo, a segurança nacional justificaria essas práticas - como também previsto no artigo da LAI.

Mas será que o cerceamento de liberdades deve ocorrer, nesses casos? A segurança nacional foi efetivamente atingida? Existem possibilidades que autorizam o Estado a se imiscuir na vida privada dos cidadãos? Questões que não são o foco desta tese, contudo, que merecem o olhar percuciente do analista, pois tratam de valores fundamentais para a democracia, que já é um sistema muito delicado e não deve ficar aberto para agressões de tal monta.

617 “EUA pagaram empresas de internet para espionarem.” Disponível em: <http://www1.folha.uol.com.br/fsp/mundo/125614-eua-pagaram-empresas-de-internet-paraespionarem.shtml>. Acesso em: 24 ago. 2013.

618 Snowden afirmou que os Estados Unidos espionaram o Brasil, que manifestou sua revolta com o fato. Em seguida, o jornal Folha de S. Paulo mostrou que o Brasil já sabia que era espionado, desde 2001, e que também praticava contraespionagem, a qual, conforme entendimento do Ministro da Justiça, José Eduardo Cardozo, “[...] é uma situação completamente diferente.” Cf. "Ministro da Justiça vê diferença entre espionagem feita pelo Brasil e pelos EUA.” Disponível em: <http://www1.folha.uol.com.br/poder/2013/11/1367026-ministro-da-justica-ve-diferenca-entreespionagem-feita-pelo-brasil-e-pelos-eua.shtml>. Acesso em: 05 nov. 2013.

619 Organização sem fins lucrativos, com sede na Suécia, que publica em seu site informações confidenciais enviadas por fontes anônimas relativas a governos e empresas.

620 Ex-analista da inteligência norte-americana que revelou programas confidenciais de vigilância eletrônica dos Estados Unidos e do Reino Unido. 


\subsubsection{Marco Civil da Internet}

A regulação de um Marco Civil da Internet vai ao encontro da necessidade de construção de políticas públicas que incrementem a participação cidadã. Considerada a “Constituição da rede”, esse documento disciplina direitos e liberdades dos cidadãos brasileiros, no ambiente das redes informáticas, e aborda temas abrangentes, como liberdade de expressão, privacidade do direito dos usuários, responsabilidade por danos decorrentes de conteúdo gerado por terceiros, guarda de registros, além do tema mais debatido, associado à neutralidade da rede.

Notável foi o estímulo dado à participação popular na Internet, quando da elaboração das propostas ao texto encaminhado ao Poder Legislativo. Por meio de uma plataforma baseada em software livre, o Ministério da Justiça e o Centro de Tecnologia da FGV/RJ traçaram as coordenadas para promover um amplo debate público, sendo que o texto elaborado ao final também foi submetido à apreciação em rede. O Projeto de Lei 2.126/11, nascido diretamente dessa rodada de discussões e sugestões, afirma, em seu art. $7^{0}$, que o acesso à Internet é “[...] essencial ao exercício da cidadania”, o que demonstra a compreensão do governo e da população sobre a importância dessa ferramenta para a sociedade democrática.

Um dos pontos polêmicos do projeto e que tem postergado sua aprovação até o presente momento é o da neutralidade da rede. A garantia da neutralidade é prevista no projeto de lei como um dos princípios do uso da Internet, no Brasil, conforme dispõe seu art. $3^{\circ}$, inc. IV.

$\mathrm{O}$ art. $9^{\circ}$ trata do tráfego de dados e explica o conceito de neutralidade de rede, nos seguintes termos:

Art. $9^{\circ}$. O responsável pela transmissão, comutação ou roteamento tem o dever de tratar de forma isonômica quaisquer pacotes de dados, sem distinção por conteúdo, origem e destino, serviço, terminal ou aplicativo, sendo vedada qualquer discriminação ou degradação do tráfego que não decorra de requisitos técnicos necessários à prestação dos serviços, conforme regulamentação. 
Parágrafo único. Na provisão de conexão à Internet, onerosa ou gratuita, é vedado monitorar, filtrar, analisar ou fiscalizar o conteúdo dos pacotes de dados, ressalvadas as hipóteses admitidas em lei. ${ }^{621}$

Hoje em dia, é franqueada às operadoras a possibilidade de oferecer pacotes de diversos preços, de acordo com o serviço oferecido; por exemplo, um serviço para leitura e envio de e-mails, ou um para quem quer assistir a filmes ou jogar on-line. Conforme as empresas de telecomunicação, já que os serviços são diferentes, a cobrança também o é, o que reflete uma situação muito justa, qual seja, cobrar mais do usuário que se utiliza mais da rede. Além do mais, o consumidor deve ter liberdade de optar pelo plano que mais lhe agrada, escolhendo apenas usar um serviço em detrimento de vários.

Essa é uma situação aceita pela lei e que não está em discussão. Não obstante, as operadoras insistem em relacionar esse fato com a neutralidade da rede, sustentando que o governo quer acabar com essa possibilidade de escolha de planos diferentes.

Contudo, a neutralidade da rede se refere a condições iguais de navegação, e não a planos de cobrança diferenciados. Explicando melhor: no ambiente virtual, os serviços são disponibilizados e, ao tentar acessá-los, os consumidores entram em uma espécie de fila. Atualmente, os consumidores que pagam mais, em um plano, acessam os serviços mais rapidamente, ou seja, é como se eles fossem para o primeiro lugar da fila apenas em razão de um critério econômico. As pessoas que pagam menos também terão acesso ao conteúdo, porém, demorarão mais tempo para ter acesso ao que desejam.

Outra situação desconfortável imposta ao usuário que paga menos pelo plano é que, como o acesso dele é mais lento, pode ocorrer de ele acessar uma página e demorar muito para conseguir visualizar outro conteúdo. Nesse caso, é como se ele ficasse refém de informações sobre as quais não tem interesse ou, no cenário político, ele pode ser obrigado a permanecer em uma página visualizando mensagens políticas com as quais não concorda.

621 BRASIL. Projeto de Lei 2.126/2011. Apresentado na Câmara em 24/08/2011. Situação do projeto: em tramitação. O projeto criará o Marco Civil da Internet, definido regras a respeito dos direitos, deveres e princípios para o uso da ferramenta no Brasil. 
Enfatiza Parajó:

O que de fato está em jogo na regra da neutralidade de redes é garantir que todos os conteúdos trafeguem nas redes em condições iguais, sem privilégio a nenhum conteúdo. Impor barreiras ou prioridades para o acesso a determinados conteúdos é limitar a liberdade de acesso à informação. ${ }^{622}$

Por conseguinte, a defesa da neutralidade da rede possibilita que todos usem os mesmos serviços com a mesma qualidade, garantindo a isonomia e evitando a limitação na transmissão, recepção ou emissão de dados. Seus defensores ${ }^{623}$ afirmam que, com ela, o caráter democrático da Internet estaria preservado, porque todos os dados receberiam o mesmo tratamento e todos os usuários sairiam beneficiados.

Entretanto, ainda não houve a adesão das operadoras de telecomunicações a esse pacto, porque, sendo aprovada a imposição da neutralidade, são as empresas de telecomunicação que ficarão responsáveis pela implementação de uma infraestrutura mais robusta e, por isso, mais cara. Os altos investimentos teriam que ser feitos por essas empresas, que precisariam ampliar e manter a capacidade da rede. ${ }^{624}$

Os artigos 10, 11 e 12 têm suscitado outro acalorado debate. Eles tratam da guarda de registros, como segue:

Art. 10. A guarda e a disponibilização dos registros de conexão e de acesso a aplicações da Internet [...] deve atender à preservação da intimidade, vida privada, honra e imagem das partes direta ou indiretamente envolvidas.

622 PARAJÓ, Eduardo Fumes. Marco civil: por uma internet livre. Disponível em: <http://www1.folha.uol.com.br/fsp/opiniao/87417-marco-civil-por-uma-internet-livre.shtml>. Acesso em: 7 jan. 2013.

${ }^{623} \mathrm{O}$ relator do texto do Marco Civil, deputado Alessandro Molon (PT-RJ), é seu principal defensor, mas tem tido dificuldades para levar o texto para votação. Já Eduardo Cunha (PMDB-RJ) apresentou uma emenda para alterar os termos da neutralidade da internet, sendo um dos que se opõem ao texto. A previsão é que a votação ocorra em fevereiro de 2014. Até lá a pauta da Câmara segue trancada. Disponível em: <http://ultimosegundo.ig.com.br/politica/2014-01-04/marco-civil-da-internet-seraprimeiro-embate-do-ano-entre-governo-e-pmdb.html>. Acesso em 04 jan. 2014.

${ }^{624}$ A pauta de sessões ordinárias na Câmara está trancada pelo projeto do marco civil da internet. O governo tem afirmado que admite mudanças técnicas na nova versão, mas que elas não atingirão a neutralidade da rede. A bancada do PMDB não aceita a neutralidade, nos termos propostos, alegando que os custos do acesso à Internet no país ficariam muito altos. 
$\S 1^{\circ} \mathrm{O}$ provedor responsável pela guarda somente será obrigado a disponibilizar as informações que permitem a identificação do usuário mediante ordem judicial [...]

Art. 11. Na provisão de conexão à Internet, cabe ao administrador do sistema autônomo respectivo o dever de manter os registros de conexão, sob sigilo, em ambiente controlado e de segurança, pelo prazo de um ano, nos termos do regulamento.

Art. 12. Na provisão de conexão, onerosa ou gratuita, é vedado guardar os registros de acesso a aplicações de Internet.

Art. 13. Na provisão de aplicações de Internet é facultado guardar os registros de acesso dos usuários [...]

Destarte, fica determinado pelo Projeto de Lei 2.126/11que os provedores de conexão, como a Net e a Telefônica, por exemplo, e aqueles que controlam os sites só são obrigados a liberar dados armazenados referentes aos usuários, se houver decisão judicial nesse sentido. Outrossim, os provedores de conexão ficariam proibidos de registrar a atividade de seus clientes, como, por exemplo, os sites acessados por eles. Desse item as empresas discordam, porque essas informações sobre os interesses e preferências dos usuários de seus serviços são preciosas, podendo ser vendidas várias vezes por altos valores. O advento da lei coibiria essa prática. Os provedores seriam obrigados a guardar, sob sigilo, o registro de conexão de seus clientes pelo prazo de um ano, sendo vedada a prática de terceirização do armazenamento ou a fiscalização de seu conteúdo.

Se aprovado o projeto de lei, os sites, provedores, portais e aplicativos terão a opção de guardar os logs de acesso, como dispõe seu art. 13. Eles seriam obrigados apenas se houvesse determinação judicial nesse sentido. Alguns deputados não concordam com esse item, pois entendem que a guarda desses dados é útil, em caso de investigação cível ou criminal, e deveria ser estabelecida sua obrigatoriedade, para servir aos propósitos de uso da polícia ou da Justiça. O relator do projeto não impôs a obrigatoriedade, afirmando que o custo seria muito alto para as empresas.

Destaca-se, ainda, o tema da retirada de conteúdo. Prevê o art. 15 do projeto:

Salvo disposição legal em contrário, o provedor de aplicações de Internet somente poderá ser responsabilizado por danos decorrentes de conteúdo gerado por terceiros se, após ordem judicial específica, não 
tomar as devidas providências para, no âmbito do seu serviço e dentro do prazo assinalado, tornar indisponível o conteúdo apontado como infringente.

Isso quer dizer que sites como o YouTube ficariam isentos de responsabilidade pelo conteúdo que hospedam, se esse material tiver sido produzido por terceiro. Eles apenas seriam responsabilizados em caso de desobediência a uma ordem judicial de remoção.

Essas questões relativas à rede são importantes para proteger os usuários, promover a colaboração e oferecer segurança jurídica. Infelizmente, transformou-se em um projeto de lei que entrou em pauta várias vezes, na Câmara, mas não tem perspectiva de ser retomado. Esse projeto tão importante, que é comparado a uma Constituição, e é citado e elogiado por estudiosos de outros países ${ }^{625}$ pela sua inovação e especificidades, projeto fruto de um amplo debate que contou com a participação dos cidadãos, não consegue vingar, por falta de atuação do governo na articulação política do Congresso, que vê o lobby das empresas de telecomunicação impor seus interesses, em detrimento dos interesses dos consumidores, dos internautas, dos representados, ou seja, do povo. Privilegiar o demos com a aprovação do marco civil, nos termos apresentados inicialmente pelo relator e pela sociedade civil, não deveria ser tarefa tão contestada pelos representantes.

\subsubsection{Posicionamento do TSE sobre o Twitter}

A Constituição Federal previu a Justiça Eleitoral, definindo como seu órgão de cúpula o Tribunal Superior Eleitoral, com jurisdição nacional. A característica peculiar desse órgão é a sua competência regulamentar, pela qual esse tribunal pode criar regras para tratar de situações não previstas em lei.

O TSE é um órgão extremamente atuante, dada a dinâmica social e as novas realidades que se esboçam diariamente, na seara político-eleitoral. Alguns casos que o TSE tem enfrentado recentemente envolvem as modificações trazidas pela Internet e o uso de suas plataformas e redes sociais, durante as eleições.

625 Ressaltamos o artigo The fallacy of “equal” treatment in Brazil’s bill of rights for Internet users, de autoria de J. Gregory Sidak, publicado no Brasil, na Revista Direito GV. São Paulo, p. 651-676, jul./dez. 2012. 
A definição, uso e características das redes sociais já foram vistas previamente, bem como as regulamentações legais sobre seu uso, durante as campanhas eleitorais. No artigo 57-A da Lei $\mathrm{n}^{0}$ 12.034/2009, ficou determinado que as redes sociais como Facebook, Twitter e Messenger só poderão ser empregadas para propaganda eleitoral após o dia 5 de julho do ano da eleição. Qualquer uso antes dessa data é considerado propaganda eleitoral antecipada, à qual são aplicadas multas.

Todavia, no dia 12 de setembro de 2013, por maioria de votos, o Tribunal Superior Eleitoral decidiu que manifestações políticas por meio da rede social Twitter não são passíveis de ser denunciadas como propaganda eleitoral. Essa decisão inédita e inovadora contraria o disposto no art. 57-A supracitado, porém, está em consonância com a definição dessa rede de rápida transmissão de informações entre os atores que nela interagem.

A decisão foi prolatada em Representação Eleitoral interposta pelo Ministério Público, que acusou Rogério Marinho de postar em sua conta no Twitter pronunciamentos de lideranças políticas do Estado do Rio Grande do Norte, todas favoráveis à sua pré-candidatura. As manifestações de apoio foram “twittadas” (como se expressou, no voto, o ministro relator Dias Toffoli) no dia $1^{\circ}$ de junho de 2012, em evento realizado pelo PSDB E DEM. Para o Ministério Público, o fato teria caracterizado propaganda eleitoral extemporânea.

A sessão de julgamento teve início com o ministro Dias Toffoli, que citou as frases de apoio escritas no Twitter, reconhecendo que elas possuíam conteúdo eleitoral; entretanto, em seguida, asseverou o ministro que "[...] essa rede social [Twitter] não pode ser considerada um meio apto a caracterizar propaganda eleitoral antecipada”. ${ }^{626}$

Seguiu o ministro, enfatizando que, para ele, Twitter “[...] é aquilo que podemos chamar de cochicho: uma pessoa cochicha com outra. Seria necessário, então, impedir que antes do período permitido para propaganda eleitoral, as pessoas, numa conversa, perguntassem umas para as outras em quem votarão”, ${ }^{627}$

\footnotetext{
626 BRASIL. TSE. Respe $n^{\circ}$ 74-64.2012.6.20.0003/RN. Relator Min. Dias Toffoli, p. 5..

627 Ibidem.
} 
Posicionou-se, pois, o ministro pela defesa da liberdade de expressão e da manifestação do pensamento em um meio empregado para as pessoas se comunicarem com seus amigos e familiares, ou com pessoas autorizadas pelo usuário, revelando-se impossível proibir a manifestação de um entendimento político em um ambiente como esse.

Acrescenta, ainda, que “[...] impedir a divulgação de um pensamento ou opinião, mesmo que de conteúdo eleitoral no período vedado pela legislação eleitoral, em uma rede social restrita como o Twitter é impedir que alguém converse com outrem”. 628

A gravidade da situação é latente. Realmente, como cumprir o mandamento legal em um espaço de conversação reservado, em que uma pessoa deve estar "seguindo" a outra, para que a mensagem seja transmitida? Como poderia a Justiça Eleitoral tomar conhecimento de todas as conversas no Twitter que podem, eventualmente, se referir a um assunto eleitoral? Como controlar essas informações diariamente, para dar cumprimento à lei? Por tudo isso é que entendeu o ministro que, não obstante ter havido manifestação de apoio para candidatura em momento inoportuno, o Twitter não é um espaço passível de controle, quando se trata de propaganda eleitoral.

No mesmo sentido foi o voto do Ministro Castro Meira, para quem o Twitter “[...] é comunicação restrita, fechada e não constitui meio de comunicação amplamente acessível a todos os destinatários.” ${ }^{629}$ Dessa maneira, o destinatário só terá acesso à mensagem se ele assim o desejar. Quem acessa o Twitter “[...] tem plena liberdade de não receber nenhuma comunicação” e, por isso, não há que se falar em propaganda em ambiente em que o acesso à informação é tão restrito.

A Ministra Luciana Lóssio fundamentou seu voto reconhecendo que o cerne da questão estava no fato de não se falar “in casu” de participação involuntária. "Só recebe mensagem de twitter quem deseja, quem vai atrás da informação”, ${ }^{630}$ ponderou a

\footnotetext{
628 Ibidem.

629 Idem, p. 8.

630 Idem, p. 9.
} 
ministra, a qual continuou, afirmando que “[...] é completamente diferente, por exemplo, do outdoor, que é colocado na rua e a pessoa é obrigada a ver a propaganda”.

De fato, no Twitter, a participação só pode ser voluntária, pois ela exige um cadastramento prévio e que a pessoa "siga” um grupo ou outra pessoa na rede. Como não é uma opinião ou manifestação generalizada, apta a atingir um público indeterminado, como no outdoor, não pode haver a propaganda irregular. Ademais, proibir esse tipo de conversa restrita com pessoas do círculo de relacionamento é censurar o diálogo, qualquer que seja ele, situação proibida constitucionalmente.

Insta salientar a continuidade do voto da ministra, ao trazer à tona o tema do direito de resposta, questão que deve suscitar dificuldades de cumprimento na mesma linha apontada neste debate.

A Lei no 12.034/2009, em seu art. 58, § 3, IV, “a”, “b” e “c”, previu o direito de resposta em propaganda eleitoral na Internet. Segundo o dispositivo legal, ele se dará no mesmo veículo, local e durante o mesmo tempo que manifestação ofensiva, cabendo ao responsável pela ofensa pagar os custos da resposta.

Contudo, em um ambiente dinâmico como o da Internet e, mais ainda, das redes sociais, no qual as mensagens são postadas e, imediatamente após, podem ser respondidas, qual seria o fundamento desse artigo? Consegue essa regra legal atingir sua real finalidade ou propósito? Conforme assinalado pela ministra Lóssio, as ações de direito de resposta avolumariam sobremaneira a Justiça Eleitoral, a qual, ou se dedicaria quase que integralmente apenas à sua análise, ou teria que arregimentar número impensável de juízes para a tarefa, sendo que a pessoa que se sentiu insultada pode postar sua resposta no mesmo ambiente e na mesma hora. E a contrarresposta pode ser emitida logo em seguida.

Portanto, esse parece ser outro ponto da lei fadado a não vingar, ficando aqui mais uma proposta de modificação legal no sentido de reelaboração do texto normativo para adequar o direito de resposta à praticidade proporcionada pelo Twitter, Facebook ou Messenger, nos termos demonstrados pela ministra Luciana Lóssio, no presente voto. 
Em sequência, o Ministro Admar Gonzaga diferencia manifestação política de propaganda eleitoral antecipada, afirmando a impossibilidade de verificação desta última em um ambiente restrito como o do Twitter, espaço onde há liberdade de comunicação e expressão, e no qual afirmações de toda sorte podem ser feitas, sem que o Ministério Público as interprete como propaganda antecipada.

Para deixar assente que o Twitter é um ambiente do qual só participam as pessoas autorizadas, o ministro compara essa rede social com a propaganda veiculada via spam, “[...] em que minha privacidade é invadida, pois eu não autorizei, não forneci meu e-mail e chateiam-me diariamente com propagandas, muitas delas bastante desagradáveis.”631

Carmen Lúcia profere o último voto, que segue o entendimento do relator, voto esse que reafirmou sua posição já manifestada em outra ação. Neste voto em análise, a ministra compara o Twitter a “[...] uma mesa de bar virtual”, um local “[...] onde se assentam e se põem as pessoas que querem.” Conclui, no mesmo diapasão que os ministros já mencionados, afirmando que esse ambiente não é “[...] instrumento de veiculação de propaganda.”,632

Divergiram a ministra Laurita Vaz e o ministro Marco Aurélio.

Para a primeira, o Twitter é “[...] amplamente utilizado para divulgação de ideias e informações ao conhecimento geral”. ${ }^{633}$ Como as frases proferidas possuíam cunho eleitoral, então, era caso de propaganda eleitoral extemporânea. Assim, entendeu a ministra que, sendo o Twitter uma rede social na qual várias pessoas e serviços interagem, haveria uma propaganda generalizada, com atingimento da lei. Não mencionou a necessidade de autorização para participar do diálogo nessa rede social.

O ministro Marco Aurélio, por fim, relembrou que nem mesmo a liberdade de expressão é absoluta e que, se houve “[...] divulgação de discursos proferidos em evento partidário, por meio de rede social”, configurada estava a propaganda antecipada. E

\footnotetext{
631 Idem, p. 10.

632 Idem, p. 12.

633 Idem, p. 6-7.
} 
inferiu que "[...] o fato de se dizer que recebe a comunicação apenas quem quer não descaracteriza a propaganda antecipada”. ${ }^{634}$

Essa é, sem dúvida, uma decisão de fundamental importância e que norteará julgamentos em outras instâncias, ampliando seus efeitos até mesmo sobre o comportamento eleitoral.

Observados os comentários ${ }^{635}$ dos partidários de Marinho, nessa ação em particular, não há que se negar que era caso de propaganda eleitoral. As frases “twittadas”, apesar de não pedir expressamente votos, nem fazer menção às eleições - o que, por sinal, não é essencial à caracterização da propaganda eleitoral antecipada -, mostravam a pretensão de Rogério Marinho de lançar-se candidato ao cargo de prefeito de Natal.

Por outro lado, tem entendido o TSE que, para restar evidenciada a propaganda eleitoral, é fundamental o conhecimento generalizado. Nesse sentido:

[...]. Propaganda antecipada. Divulgação. Texto. Internet. Blog Conotação eleitoral. Presente. [...]. 1. Nos termos da jurisprudência da Corte, deve ser entendida como propaganda eleitoral antecipada qualquer manifestação que, antes dos três meses anteriores ao pleito, leve ao conhecimento geral, ainda que de forma dissimulada, a candidatura, mesmo que somente postulada, a ação política que se pretende desenvolver ou as razões que levem a inferir que o beneficiário seja o mais apto para a função pública. [...] 3. A garantia constitucional da livre manifestação do pensamento não pode servir para albergar a prática de ilícitos eleitorais, mormente quando está em jogo outro valor igualmente caro à própria Constituição, como o equilíbrio do pleito. 4. Divulgada, por meio de página na internet, a candidatura e os motivos pelos quais a candidata seria a mais apta para o exercício do cargo público, é de se reconhecer a prática de propaganda antecipada; [...] (grifo nosso). ${ }^{636}$

[...] Propaganda eleitoral antecipada. Programa partidário. Notório pré-candidato. Apresentação. [...] Promoção pessoal. Tema políticocomunitário. Abordagem. Conotação eleitoral. Caráter implícito. Caracterização. Procedência. Recurso. Desprovimento. [...] 2. Nos

\footnotetext{
634 Idem, p. 12.

635 Algumas frases reproduzidas no voto do Ministro Dias Toffoli e que transcrevemos aqui: "A précandidatura de Rogério Marinho é o que Natal está precisando”, ou "Rogério Marinho é dono de emendas que beneficiam o desenvolvimento do RN e de Natal”. Idem, p. 5.

636 BRASIL. TSE. Ac. De 17.3.2011 no R-Rp no 203745. Rel. Min. Marcelo Ribeiro.
} 
termos da jurisprudência da Corte, deve ser entendida como propaganda eleitoral antecipada qualquer manifestação que, previamente aos três meses anteriores ao pleito e fora das exceções previstas no artigo 36-A da Lei $n^{\circ} 9.504 / 97$, leve ao conhecimento geral, ainda que de forma dissimulada, a candidatura, mesmo que somente postulada, a ação política que se pretende desenvolver ou as razões que levem a inferir que o beneficiário seja o mais apto para a função pública. 3. A configuração de propaganda eleitoral antecipada não depende exclusivamente da conjugação simultânea do trinômio candidato, pedido de voto e cargo pretendido. [...] 5. Caracteriza propaganda eleitoral antecipada, ainda que de forma implícita, a veiculação de propaganda partidária para promoção de filiado, notório pré-candidato, com conotação eleitoral, que induza o eleitor à conclusão de que seria o mais apto para ocupar o cargo que pleiteia, inclusive com a divulgação de possíveis linhas de ação a serem implementadas. [... $]^{637}$

No primeiro exemplo, que trata de propaganda eleitoral difundida em um blog, ferramenta que pode ser acessada por qualquer pessoa, a interpretação procede. Todavia, em se tratando de Twitter, como bem lembrado pelos doutos ministros, só é possível haver o diálogo com quem possui uma participação previamente aceita. O ambiente é, sem dúvida, restrito. As informações divulgadas não são do conhecimento de todos. Para que haja troca de informações, é imprescindível que uma pessoa esteja “seguindo” a outra. Em razão disso, é inquestionável a nova orientação do TSE.

Apesar da menção feita por alguns ministros à R-Rp no $182524,{ }^{638}$ de relatoria do Ministro Aldir Passarinho, a qual também tratava de propaganda eleitoral nessa mesma rede social e que teve entendimento contrário, não resta dúvidas de que melhor compreensão do tema foi alcançada com este último julgamento do TSE, que se posicionou de forma contrária ao disposto no art. 58 da Lei $\mathrm{n}^{0}$ 12.034/2009, mas respeitou o funcionamento e a estrutura da rede social Twitter.

637 BRASIL. TSE. Ac. De 10.8.201. no R-Rp n $n^{\circ}$ 177413. Rel. Min. Joelson Dias.

638 “Eleições 2010. Propaganda eleitoral extemporânea. Twitter. Caracterização. Arts. 36 e 57-A da Lei $\mathrm{n}^{\circ}$ 9.504/97. [...]. 2. Constitui propaganda eleitoral extemporânea a manifestação veiculada no período vedado por lei que leve ao conhecimento geral, ainda que de forma dissimulada, futura candidatura, ação política que se pretende desenvolver ou razões que levem a inferir que o beneficiário seja o mais apto para a função pública. 3. Na espécie, as mensagens veiculadas no Twitter do recorrente em 4 de julho de 2010 demonstraram, de forma explícita e inequívoca, a pretensão de promover sua candidatura e a de José Serra aos cargos de vice-presidente e presidente da República nas Eleições 2010. [...]” Ac. De 15.3.2012 no R-Rp $n^{o}$ 182524. Rel. Min. Aldir Passarinho Junior. 
Essa decisão de 2013 provocará grandes efeitos nas eleições de 2014, e já previu, inovador que foi, o problema igualmente colocado pela Lei $n^{0} 12.034 / 2009$, ao estabelecer direito de resposta na Internet, sem levar em conta seu dinamismo, o que pode ensejar longos processos judiciais, os quais, ao fim, serão inócuos. 


\title{
CAPÍTULO V - INTERNET E ELEIÇÕES: UM NOVO AMÁLGAMA NA DEMOCRACIA. MODELOS ESTRANGEIROS
}

\author{
Minha pátria é minha infância: \\ Por isso vivo no exílio \\ Antônio Carlos de Brito ${ }^{639}$
}

\begin{abstract}
O estudo de caso de diversos modelos estrangeiros representa um importante recurso de pesquisa, porque, além de despertarem um interesse ilustrativo, diferentes modelos ajudam a compreender os limites à satisfação de determinadas necessidades, em outras culturas e histórias. Ademais, por meio desse recurso, pode-se vislumbrar o que está sendo feito em outros países para aprimorar modelos que agregam valores por vezes tão distintos. Entretanto, convém ressaltar que o estudo de caso possui um valor relativo, devido a todos os fatores condicionantes de uma determinada sociedade. É com atenção a essa ressalva que passamos à análise das três situações, as quais servem como um ponto de partida para estudos aprofundados sobre o uso da Internet em momentos eleitorais.
\end{abstract}

O primeiro exemplo de modelo estrangeiro que obteve resultados impressionantes, ao estimular o acesso à Internet durante as eleições é, sem dúvida, o dos Estados Unidos, por ocasião das eleições presidenciais do ano de 2008. A bemsucedida campanha de Barack Obama, que obteve vultosa arrecadação pela Internet, já virou lugar comum nessa discussão. Nem por isso esse modelo deve ser deixado de lado, em nossa análise, pois o paradigma por ele estabelecido ainda não foi superado, devendo ser constantemente revisto, para o seu completo entendimento.

A Estônia, por sua vez, é lembrada por possuir um modelo exclusivo de votação eletrônica em esfera nacional, mesmo o cidadão estando à distância (voto eletrônico remoto), o que representa um impulso à participação cidadã, o qual merece reconhecimento e acolhimento por outros países.

639 BRITO, Antônio Carlos de (CACASO). Lar doce lar. In: São Paulo: Cosac \& Naify, 2002, p. 53. . Lero-lero. Rio de Janeiro: 7 Letras; 
Por fim, fazemos menção às últimas eleições legislativas italianas, ocorridas no ano de 2013, em função da visibilidade alcançada pelo Movimento 5 Estrelas e por Beppe Grillo, humorista e líder do movimento, que, com uma campanha centrada na Internet, fez de sua plataforma online a terceira força política na Itália.

\subsection{0 modelo norte-americano}

A surpreendente habilidade no emprego dos meios digitais, nas eleições presidenciais norte-americanas de 2008, representa um divisor de águas nos estudos sobre campanhas eleitorais. Até então, um dos estudos mais importantes que relacionavam esses dois fatores havia sido desenvolvido por Bimber e Davis, ${ }^{640} \mathrm{em} \mathrm{um}$ importante registro sobre as campanhas presidenciais de 2000, nos Estados Unidos. Os autores concluíram, à época, que as campanhas políticas na Internet provocariam resultados mínimos na definição do resultado e não afetariam aqueles que já possuíam opinião formada. Essa foi uma das primeiras obras a apresentar dados consistentes sobre a campanha política na Internet.

Depois disso, é apenas na primeira campanha eleitoral de Obama que a Internet passa a ser um instrumento com eficácia eleitoral. Como explicam Gomes et al., ${ }^{641}$ Obama inovou, ao explorar as mídias sociais para obter doações para sua campanha, mas a estratégia seguida para chegar a esse ponto foi ainda mais surpreendente.

A campanha de Obama teve uma eficiente coordenação de recursos de comunicação digital da web 2.0, gerenciada por um dos fundadores do Facebook, Chris Hughes, contratado um ano antes das eleições. A partir disso, foi criado o site www.barackobama.com, cuja ideia inicial era simplesmente dar aos eleitores a chance de conhecer o candidato, mostrando sua biografia, os cargos políticos que havia exercido, suas posições e programas políticos.

Em seguida, foi desenvolvida uma rede social específica para o candidato, denominada MyBO (“My.Barack.Obama”). Com isso, as pessoas podiam participar e

640 BIMBER, B.; DAVIS, R. Campaining on-line: the Internet in the U.S. elections. New York: Oxford University, 2003.

${ }^{641}$ GOMES, Wilson; FERNANDES, Breno; REIS, Lucas; SILVA, Tarcísio. Politics 2.0: a campanha online de Barack Obama em 2008. Revista Sociológica Política, Curitiba, v. 17, out. 2009. 
interagir, criando perfis, divulgando eventos, compartilhando mensagens e histórias. Era Obama conquistando a confiança de seus eleitores.

O site de Obama, ademais, possuía links para várias outras mídias sociais, tanto as mais conhecidas, como Facebook, YouTube ou MySpace, até aquelas que são formadas por segmentos da sociedade americana, como a MiGente, dos hispânicos, AsianAve, dos asiáticos, ou Glee (Gay, Lesbian and Everyone Else), dos homossexuais.

A estratégia era simples: usar intensamente as mídias sociais para aproximar Obama de seus eleitores. O projeto foi elaborado com base na peculiaridade de cada mídia social, aproveitando os instrumentos disponíveis em cada uma delas, e teve fácil aceitação, exatamente porque já eram usadas pelos eleitores em geral com acesso ao Facebook, LinkedIn, MySpace etc. Bastava somente um clique para descobrir o candidato à Presidência e interagir com ele, convidando, aliás, amigos, colegas de trabalho, vizinhos e familiares para participarem dessa congregação.

O uso dessas redes sociais promoveu um diálogo horizontal, estabelecido entre todos em igualdade de condições, no ambiente virtual, e travado com facilidade pelos participantes. A mensagem era simples e constante, não exigia conhecimento técnico e nem mesmo político das pessoas, o que atraiu vários grupos sociais e aproximou os cidadãos da política, além de possivelmente ter aproximado entre si cidadãos de uma mesma comunidade. Obviamente, também, atraiu grande número de jovens, maior grupo de usuários das mídias sociais.

Como já exemplificado no Capítulo 3, o site exibido no YouTube que divulgava vídeo no qual apareciam vários artistas americanos musicando discurso de Obama teve mais de 16 milhões de visualizações, além de ter recebido o "Webby Awards”, ${ }^{642}$ considerado o prêmio máximo da Internet. Outra iniciativa interessante foi a do Youbama - www.youbama.com -, uma campanha feita pelos próprios cidadãos na qual eles postavam vídeos mostrando suas razões de por que votar ou não votar em Obama. Ser simpatizante ou não deixa de ser o foco dessa plataforma; o mais

642 Disponível em: <http://en.wikipedia.org/wiki/Yes_We_Can_(will.i.am_song)>. Acesso em: 4 out. 2012. 
importante é o acesso a um espaço em que os cidadãos produzem o conteúdo, sem intermediações, sem cerceamento à liberdade de expressão.

Foi apenas depois disso que a campanha foi direcionada para pedidos de doação. Todavia, nesse momento, Obama já havia criado um vínculo com os eleitores, que se sentiam próximos dele. A doação parecia algo natural, e o foi. Dos 650 milhões arrecadados, 500 milhões vieram da Internet, um número surpreendente. Ferrari afirma que Obama poderia até mesmo ter aberto mão do financiamento público de campanha e descreve o painel eleitoral:

Foi uma massa conectada que gerou mais de 13 milhões de streamings da CNN/Facebook sobre a cobertura da eleição presidencial de Barack Obama. O site da Casa Branca mudou após a posse de Obama e, agora, aglutina aspectos antropológicos da rede, ou seja, sai a informação como vetor e entram em cartaz as redes sociais como processo de troca de conhecimentos e conteúdos. Você também pode falar com Barack Obama! Em 21 de janeiro de 2009, dia seguinte à posse, o blog da Casa Branca amanheceu com diversas mudanças, todas voltadas para a disseminação das redes sociais na administração de Barack Obama, que pretende se conectar através da rede com o povo americano, aumentando a comunicação entre o governo e 0 eleitor. ${ }^{643}$

Por fim, o movimento ganhou tanta força que arregimentou um expressivo número de voluntários, os quais iam para as ruas bater às portas, dirigindo-se aos eleitores da forma mais prosaica e conhecida pelo universo político. Estabeleceu-se, com isso, um modelo totalmente diferente das campanhas políticas anteriores. ${ }^{644}$

Não só o volume de doações, mas todos os números envolvendo essa campanha na Internet causam espanto.

O Pew Research Center for the People and the Press, instituto independente que realiza pesquisas de opinião referentes a política, imprensa e assuntos de política

643 FERRARI, Pollyana. A força da mídia social. São Paulo: Factash, 2010, p. 45.

644 No Brasil são feitas campanhas políticas na Internet, mas nenhuma delas teve, ainda, expressão política considerável. Também podemos mandar e-mails para os representantes ou partidos políticos, mas as chances de o e-mail chegar diretamente ao nosso candidato ou de termos uma resposta vinda diretamente dele são pequenas. O que se verifica, aqui, são usos mais modestos das ferramentas da Internet, que estão longe de ser usadas intensamente para atividades políticas, o que precisa ser cada vez mais incentivado. 
pública, noticiou, à época, que um terço dos americanos acompanhou as primárias, ${ }^{645}$ um número muito alto, somente visto durante o pico da campanha eleitoral. A conclusão tirada foi a de que os americanos não só estavam acessando as mídias sociais e sites para obter informações políticas, mas que também estavam participando de forma atuante nas conversas políticas que se propagavam no ambiente virtual.

O instituto apontou, ainda, que $46 \%$ dos adultos usaram a Internet, e-mail ou mensagens de texto enviadas por celular ${ }^{646}$ com propósitos políticos, falando sobre a campanha eleitoral, divulgando informações sobre a escolha dos candidatos ou comentando os debates. Assim:

- 40\% dos americanos (usuários típicos da Internet ou não usuários) obtiveram informações e notícias sobre a campanha de 2008 pela Internet;

- 19\% dos americanos acessavam a Internet uma vez por semana ou mais, para fazer algo associado à campanha presidencial, sendo que 6\% desenvolveram a prática política diária pela Internet;

- 23\% dos americanos disseram ter recebido e-mails pedindo apoio político a um candidato, ou que pediam participação em debates políticos, pelo menos uma vez por semana;

645 As eleições americanas possuem duas fases. Na primeira, os norte-americanos elegem os candidatos à presidência de cada partido. Para decidir quem representará o partido nas eleições, são conduzidas as primárias, para que o povo escolha os candidatos. As primárias têm início em janeiro do ano eleitoral. Na segunda etapa, é definido o Colégio Eleitoral, cujo número de delegados está relacionado ao número de habitantes do Estado. São esses delegados os responsáveis pela escolha do presidente.

646 O uso de aparelhos de celular foi bem inferior ao uso de computadores para acessar a Internet. Todavia, analistas preveem uma nova revolução política a ser promovida pela expansão dos smartphones, aparelhos simples e práticos, que permitem fácil acesso à Internet e que, em breve, ultrapassarão o número de habitantes do planeta. "O Brasil foi o quarto país onde o número de linhas mais cresceu no último ano. Foram ativadas cerca de 5 milhões de novas linhas, atrás da China (30 milhões) e da Indonésia (também 10 milhões). Em 2014, estima-se que já haverá mais linhas de celulares do que pessoas no mundo. Em 2018, serão 9,1 bilhões de celulares.” DUARTE, Maurício. O rei do tijolão. Afinal, o que é qualidade de vida? Revista da Cultura, São Paulo, 77 ed., dez. 2013, p. 61. Com o crescimento do uso do celular, as transações governamentais - e-governement - podem alcançar um novo patamar e novas potencialidades, simplificando processos e reduzindo custos, o que também aproximará cidadãos dos governos. 
- 35\% dos americanos assistiram a vídeos online relacionados à campanha presidencial;

- 10\% dos americanos usaram e-mails no sentido de contribuir para o debate político. ${ }^{647}$

Aqueles que apoiavam Obama tinham mais compromisso com a participação online do que aqueles que votariam em McCain. Além disso, o percentual de democratas que possuía perfil na rede social era de 36\%, comparado com apenas 21\% de republicanos nas mesmas condições. Os eleitores de Obama faziam mais doações, participavam mais como voluntários, se inscreviam com maior frequência para atividades ligadas à campanha e faziam questão de mostrar sua opinião política.

Se comparados os estudos desenvolvidos por esse instituto com os de anos anteriores, tem-se que, em 2004, 21\% de pessoas entrevistadas afirmaram que a principal fonte de informação era a Internet, contra 11\%, em 2000, e 3\%, em 1996. Nesse caso, como afirmam Gomes et al.,

[...] uma coisa é considerar o uso da Internet quando apenas 3,5 milhões de adultos têm acesso a ela, como nos Estados Unidos em 1994, quando se começa a empregar alguns recursos online em campanhas, e outra quando já são 200 milhões de pessoas (73\% da população) com acesso à rede mundial de computadores. ${ }^{648}$

Insta salientar a impressionante velocidade de expansão da Internet, suas formas de utilização, cada vez mais abrangentes e criativas, e o seu potencial para o fortalecimento democrático.

Desde o princípio, o site www.barackobama.com tem pretendido estimular as mudanças feitas pelos próprios cidadãos. O programa ainda em vigor, Organizing for America, visa a habilitar as pessoas para que elas possam organizar seus bairros e comunidades, reconquistando o controle das políticas locais. Já que o poder é do povo, é

647 SMITH, Aaron; RAINIE, Lee. The Internet and the 2008 election. Todos os dados disponíveis em: $<$ http://www.pewinternet.org/ /media/Files/Reports/2008/PIP_2008_election.pdf.pdf >. Acesso em: 4 out. 2012.

${ }^{648}$ GOMES, Wilson; FERNANDES, Breno; REIS, Lucas; SILVA, Tarcísio. Politics 2.0: a campanha online de Barack Obama em 2008. Revista Sociológica Política, Curitiba, v. 17, out. 2009, p. 32. 
ele quem deve estar à frente das mudanças. Essa foi uma proposta inédita e controversa, debatida e combatida, que busca aumentar a transparência das políticas públicas e aproximar governo e cidadãos. Cabe especular que talvez só esteja sendo possível levar adiante uma proposta dessas, nos Estados Unidos, por eles já possuírem mais de 200 anos de democracia estável. O novo contexto informacional apresentado pela Internet sem dúvida viabiliza essa forma de interação, ${ }^{649}$ criando um espaço privilegiado da ação política da sociedade em rede. ${ }^{650}$ As características da Internet propiciam práticas colaborativas e interativas, produzem novas relações sociais, permitem a entrada de novos atores no processo eleitoral e ampliam a participação dos cidadãos.

Esse projeto, por outro lado, pode gerar outros problemas, como uma demanda desproporcional de questões que dificultem o próprio debate ou o esclarecimento de todas as dúvidas. Entretanto, esse parece ser um problema saudável. Se ocorrer, isso significará interesse pelo debate político. E merecerá um estudo organizacional e estrutural, com adaptação dos partidos e do governo, mas que promoverá uma democratização das instituições e o envolvimento dos cidadãos no processo político. Esse cenário contribui para que a política fique mais próxima do cidadão, o que implica maior transparência, com a possibilidade de uma cobrança mais sistemática.

Ainda no contexto dos Estados Unidos, é oportuno comentar, igualmente, o programa California Internet Voting Task Force, criado no ano de 2000, pelo Secretário de Estado Bill Jones, a fim de estudar a viabilidade do uso do voto eletrônico nas eleições da Califórnia. O objetivo foi desenvolver um sistema que facultasse aos eleitores votar pela Internet. Isso seria possível de forma progressiva, dividida em quatro fases. Inicialmente, o eleitor votaria em terminais eletrônicos, em sua zona eleitoral. Na segunda fase de implementação, ele votaria da mesma maneira, mas em qualquer zona eleitoral. Em seguida, o projeto permitiria o voto eletrônico em máquinas

649 O programa consiste em um espaço no qual as pessoas se cadastram e podem debater os problemas da comunidade e propor projetos de lei, entre outras coisas. Os Congressistas, por sua vez, podem consultar os assuntos que estão sendo lá discutidos. O programa veicula, ainda, ofertas de emprego e cursos nas áreas locais. É bem verdade que tudo isso poderia, em tese, acontecer em um espaço físico, mas somente por conta da internet foi que o programa atingiu aquela dimensão e atraiu pessoas de todo o país. Esse tipo de interação e troca de ideias só acontece em função da internet. É possível organizar um evento por semestre, reunindo quinhentas mil pessoas para debater um projeto de lei? Sim, é possível, mas o processo seria bastante demorado e custoso. Segundo a plataforma do programa, as discussões sobre o Obamacare tiveram mais de cinco milhões de manifestações em alguns meses. 
que poderiam ser instaladas em diversos locais públicos. Por fim, haveria a possibilidade de votar pela Internet, a partir do computador pessoal, por meio de identificação digital ou assinatura biométrica. Portanto, a intenção não era eliminar as tradicionais cédulas de votação, mas criar uma alternativa a elas. Os sistemas poderiam coexistir, porém, de acordo com o projeto, o voto eletrônico deve ser implementado paulatinamente. Trata-se de um projeto em andamento, o qual merece ser observado com atenção, principalmente dados os trâmites que envolvem o processo eleitoral nos Estados Unidos, cujos votos levam muito tempo para ser contados, o que dá margem a situações gravíssimas, como as que marcaram as eleições presidenciais de 2000, disputadas entre Al Gore e George W. Bush. Essas eleições ficaram conhecidas pela controvérsia na contagem de votos, a qual teve origem no Estado da Flórida e que deu a vitória a Bush, que ganhou as eleições, apesar de ter recebido menos votos populares que $\mathrm{Al}$ Gore.

Considerando o modelo americano, o que deve ser salientado é a possibilidade de participação que a Internet oferece. Essa não é uma afirmação ingênua. Reconhecemos que, se, por um lado, criar um blog na internet está, em tese, ao alcance de todos, por outro lado, a capacidade de propagação de ideias políticas e a formação de grupos de debate estão estreitamente ligadas a diversos fatores. No caso da campanha de Obama de 2008, por exemplo, a eficiente coordenação de recursos de comunicação digital adotada não pode ser ignorada como uma das importantes causas para o seu sucesso. Contudo, a utilização inclusiva da Internet não se restringiu à campanha eleitoral, ampliando-se para diversos programas, o que avaliamos como muito positivo. Entendemos que, por meio da Internet, a informação política pode ser mais rica, dinâmica, interativa e, dependendo da forma como é usada, até menos dispendiosa. Os eleitores podem sentir-se motivados a se expressar, e os eleitos podem ser controlados mais de perto, exigindo maior transparência dos governantes, de suas agendas políticas e das estratégias partidárias. ${ }^{651}$

651 "It has been argued that new ICTs will be a primary tool in providing the direct link in communicating citizen's preferences to politicians. No longer will it be a case of candidates pushing their message onto the public, but through the interactive potential of new ICTs, citizens will have a greater ability to shape the campaign agenda and party strategies.” WARD, S.; GIBSON, R.; NIXON, P. Parties and the Internet. WARD, S.; GIBSON, R.; NIXON, P. (Ed.). Political parties and the Internet: net gain? London and New York: Taylor and Francis Group, 2003, p. 16. 


\section{$5.2 \mathrm{O}$ modelo estoniano}

A Estônia, pequeno país do Leste Europeu, proclamou sua independência em 1991. Fazia parte do império soviético e foi precoce ao agir, em face do esfacelamento da União Soviética. Diante desse cenário, conseguiu estruturar suas instituições governamentais e foi ousada em adotar a experiência do voto eletrônico. O fato de ter ficado por tanto tempo de sua história sob o domínio soviético fez com que o governo buscasse uma forma eficiente e simples de aproximar os cidadãos das instituições. A opção pelo voto eletrônico tem-se mostrado acertada.

Convém esclarecer que, nesse país, dois sistemas coexistem, o da votação eletrônica e o do voto depositado em urna na zona eleitoral específica do eleitor. Todavia, o voto eletrônico acontece na semana que antecede o dia da eleição nacional, porém, não no dia da eleição. Caso o eleitor queira mudar seu voto eletrônico, basta acessar o sistema e votar novamente. Somente o último voto será considerado na contagem. Em acréscimo, se, no dia da eleição, quando não é mais autorizado o voto pela Internet, o eleitor mesmo assim quiser mudar o voto mais uma vez, basta que ele proceda como os demais eleitores, dirigindo-se ao seu local de votação. Nesse caso, esse voto depositado na urna será o único reconhecido.

Existem duas modalidades de voto eletrônico. Uma delas é adotada pelo Brasil e seu renomado sistema de urna eletrônica usada no período eleitoral. O voto é contabilizado de maneira rápida e segura, mas o cidadão precisa se dirigir à zona eleitoral para efetivar o voto. É o voto eletrônico off-line.

Na Estônia, foi adotado o voto eletrônico online (também chamado voto eletrônico remoto, ou à distância), que segue todos os mandamentos básicos do sufrágio e, além disso, possibilita ao cidadão votar a partir de seu computador pessoal. Assim, o voto é secreto, o eleitor só pode apresentar um voto, é feita a prova de que o eleitor votou e o sistema não aceita votação fora do período oficial determinado para o sufrágio nacional.

A implantação desse sistema foi testada pela primeira vez nas eleições municipais de 2005, como parte do projeto de governança eletrônica do país. A votação 
foi possível por conta da aprovação da lei Digital Signature Act, em 2002, que possibilita aos cidadãos uma assinatura digital que confirma sua identidade nas transações online. Esse certificado digital pode ser usado na residência de cada um, com uma leitora de cartão, ou, então, em terminais públicos, havendo, pelos dados de 2009, 55 terminais para cada 100 mil cidadãos. ${ }^{652}$

O Digital Signature Act deu fundamento legal para a implementação do sistema e previu um prazo para que a estrutura requerida fosse montada. O voto eletrônico começou a ser possível, portanto, somente em 2005, ou seja, sua sólida estrutura não surgiu de repente: ela foi projetada e implementada ao longo de anos, exigindo investimentos em tecnologia e comunicação, para que a Internet recebesse papel de destaque nas atividades governamentais. Desse modo, não apenas essa lei, mas todas as demais regulamentações administrativas que se seguiram, aprovaram a assinatura digital para autenticar transações online, tanto as relacionadas aos serviços governamentais administrativos como a autorização para o voto eletrônico.

No primeiro ano em que ele foi usado, conforme informa o site do governo da Estônia, 9 mil cidadãos se valeram desse recurso para eleger seus candidatos, o que correspondia a $2 \%$ do número total de cidadãos aptos a votar.

O voto eletrônico remoto já foi autorizado para as seguintes votações: eleições locais, em outubro de 2005, eleições parlamentares, em março de 2007, eleições para o parlamento europeu, em junho de 2009, eleições locais, em outubro de 2009, eleições parlamentares, em março de 2011, e eleições locais, em outubro de 2013.

O crescimento do número de cidadãos que passaram a adotar o procedimento do voto eletrônico à distância demonstra que a população tem estabelecido uma relação de confiança e segurança com o modelo, admitindo sua praticidade. Como exemplo, em

652 ALVAREZ, R.; HALL, T.; TRECHSEL A. Internet Voting in Comparative Perspective: The Case of Estonia. Political Science and Politics, Cambridge, v. 42, p. 497-505, 2009. 
2009, 15\% dos eleitores declararam seu voto de seus computadores pessoais, enquanto, em 2013, esse número cresceu para 23\%. ${ }^{653}$

De acordo com Alvarez, Hall e Trechsel, ${ }^{654}$ quatro são os fatores que possibilitaram o voto eletrônico remoto na Estônia: amplo acesso à Internet, estrutura legal que regula essa modalidade de voto, sistema de identificação digital autenticado e uma cultura política que apoia o voto remoto.

O site da Comissão Europeia informa que o acesso à Internet na Estônia tem crescido rapidamente: 31\% das casas possuía Internet, no ano de 2004, número que saltou para 53\%, em 2007. Desses 53\%, 89\% estão conectadas à Internet banda larga.

As regras que conduzem esse tipo de votação no país obedecem aos princípios do voto, analisados no Capítulo 4, com algumas peculiaridades. Conforme antecipado, fica definido que, na semana que antecede o dia da eleição, os eleitores poderão votar eletronicamente. É possível, inclusive, alterar o voto e votar novamente pela via eletrônica, quando fica valendo a última escolha. Aliás, o cidadão pode até mesmo ter votado pela Internet e, no dia da eleição, ir até a sua zona eleitoral votar da forma tradicional, usando uma cédula de voto e não uma urna eletrônica, situação na qual prevalecerá esta última opção.

Alvarez, Hall e Trechsel ${ }^{655}$ discorrem sobre o procedimento que implementa o voto eletrônico.

O eleitor precisa de um cartão de identificação com uma senha (PIN code), um computador conectado à Internet e uma leitora de cartão inteligente. Um software específico para esse fim deve ser previamente instalado no computador.

Caso a senha seja perdida ou esquecida, uma nova senha pode ser solicitada ao Citizen and Migration Bureau of the Prefecture.

\footnotetext{
653 Disponível em: <http://www.vvk.ee/voting-methods-in-estonia/engindex/statistics>. Acesso em: 23 dez. 2013. Os dados estatísticos com o percentual de participação em cada eleição, separados por idade e sexo, estão presentes nesse link.

654 ALVAREZ, R.; HALL, T.; TRECHSEL A. Op. cit.

655 ALVAREZ, R.; HALL, T.; TRECHSEL. Op. cit.
} 
Como uma alternativa ao cartão de identificação, o eleitor pode optar por ter uma identificação digital. A diferença está apenas na mídia, pois o processamento do voto é o mesmo.

A leitora de cartão inteligente deve se encaixar em qualquer entrada USB tradicional dos computadores. Custa aproximadamente US\$ 7 e é capaz de identificar o número do cartão de identidade. Por isso é que o voto pode ser lançado tanto do computador pessoal do eleitor como de qualquer um dos computadores públicos à disposição da população, pois o sistema de identificação é único e exclusivo.

De posse desses itens, o eleitor insere seu cartão de identificação na leitora de cartão e acessa o sítio eletrônico www.valimised.ee. Em seguida, baixa os aplicativos necessários, identifica-se com a senha pessoal, escolhe seu candidato dentre aqueles que aparecem na lista previamente elaborada, confirma sua opção e recebe a confirmação do voto.

Nas eleições para o parlamento da Estônia (Riigikogu), no ano de 2011, foi testada pela primeira vez a identificação móvel (mobile-ID), que requer um cartão SIM de identificação móvel, com certificação e a adoção de uma senha. Para votar por meio desse sistema de identificação móvel, basta que o eleitor tenha um computador com Internet e um celular, aparelho no qual é instalado o cartão SIM, que precisa ser ativado e identificado.

Por esse sistema, o eleitor acessa o mesmo sítio eletrônico www.valimised.ee, baixa o aplicativo e coloca o número do seu celular. Insere a senha do seu cartão SIM, escolhe o candidato e recebe a notificação. Ou seja, o eleitor ainda precisa de um computador, mas pode ter acesso às senhas e certificações de autenticação pelo seu celular.

Além de receber o crescente apoio da população, o modelo de voto eletrônico remoto é visto com bons olhos também pelos partidos políticos, independentemente de que partido seja o governo. 
A Estônia é o único país do mundo que adota a possibilidade de votação nacional pela Internet, de sorte que ele tem sido observado por tantos organismos internacionais.

Aponta Norris ${ }^{656}$ que o sistema apresenta vantagens que não podem ser desconsideradas. O voto eletrônico, depois de implementado, apresenta um baixo custo de manutenção. Quanto mais adotado ele for, mais ele provocará a diminuição do gasto com urnas, com o deslocamento das urnas por locais mais distantes ou de difícil acesso, além de reduzir o número de fiscais eleitorais.

Outrossim, esse modelo tem aumentado a credibilidade do sistema eleitoral. As tentativas de fraude devem ser sempre coibidas, como em qualquer outro sistema de votação, porém, os eleitores têm acreditado nesse método e na contagem dos votos, o que diminui a desconfiança no resultado obtido pelo processo eleitoral.

O exercício do direito ao voto é amplamente facilitado para o eleitor, que pode votar estando em casa ou em qualquer outro lugar, inclusive no exterior; se ele estiver de posse dos itens necessários e tiver acesso a um computador ligado à Internet, poderá expressar sua escolha e participar das eleições, importante momento em que o cidadão é o ator principal.

Convém ressaltar, ainda, que o voto pela Internet altera a relação entre os partidos e os eleitores. Os partidos acabam ampliando o escopo dessa mídia interativa, aumentando a quantidade de informações disponíveis e prestigiando o debate on-line. Esse comportamento pode contribuir para uma modernização da linguagem partidária, alterando sua postura de campanha para se adequar à Internet.

Treschsel ${ }^{657}$ conduziu pesquisa mais específica sobre as eleições de 2007 na Estônia e concluiu que, pelo menos naquele ano, esse canal de participação foi fundamental para atrair os jovens para as eleições. Isso é bom, por um lado, mas ruim

656 Norris, P. The impact of the Internet on political activism: evidence from Europe, International. Journal of Electric Government Research, Harvard, p. 20-39, 2005.

657 TRECHSEL, Alexander. Report for the Council of Europe: Internet Voting in the March 2007. Parliamentary Elections in Estonia. Council of Europe. Disponível em: <http://votingtechnology project.org/drupal/files/report/internet_voting_estonia_2007.pdf>. Acesso em: 23 dez. 2013. 
por outro, pois o autor observou não haver grande estímulo para que pessoas de outras idades se habituassem a usar o computador. Quem já era um internauta, continuaria sendo, todavia, quem não era tenderia a se manter assim.

O autor apontou, também, que a língua é uma questão fundamental em um país tão dividido linguisticamente. As eleições de 2005 e de 2007 foram conduzidas em estoniano, o que afastou a comunidade russa do voto eletrônico. Considerando-se que há em torno de 320 mil russos no país, número que corresponde a $24 \%$ da população, essa é uma limitação que merece ser ressaltada.

Mais significativa pareceu a conclusão de que o voto eletrônico não apresentou distinções de educação, sexo ou renda, mostrando-se ser um procedimento verdadeiramente democrático.

Conforme Lulin, ${ }^{658}$ o voto pela Internet é uma realidade cada vez mais iminente, pois suas medidas são centradas no eleitor e são altamente inclusivas. A autora cita o exemplo brasileiro, modelo de voto eletrônico off line, realizado a partir de uma urna eletrônica, mas mostra as vantagens da adoção, no futuro próximo, do voto online, à distância, porque, de acordo com ela, as eleições seriam mais baratas, os resultados mais confiáveis e, acima de tudo, o sistema provocaria o aumento da participação eleitoral.

Um ponto que merece atenção é a possibilidade oferecida pela Internet de ampliação da participação política de pessoas com diversas necessidades especiais, como, por exemplo, pessoas com dificuldade de locomoção. Conquanto esse seja um ponto muito relevante, até o momento não tem recebido a devida atenção da doutrina especializada sobre o tema. Muito embora seja fundamental facilitar cada vez mais a circulação de pessoas com necessidades especiais nos espaços públicos, a existência da Internet inegavelmente amplia suas possibilidades de participação política.

A autora ressalta que não há nem mesmo o risco de desconfiança ou desinteresse dos eleitores, porquanto o objetivo não é atrair os céticos, mas estimular

658 LULIN, Elisabeth. Voter par internet: un futur proche. Commentaire, Paris, n. 91, p. 530, Automne 2000. 
aqueles que já fazem uso da Internet e que estarão abertos à sua utilização pela praticidade que ela oferece. $^{659}$

Por outro lado, Lulin observa um dos lados negativos do voto eletrônico online, que repousa na ideia de que o voto é muito mais do que um gesto individual do eleitor expressando sua preferência política. $\mathrm{O}$ voto é um ritual coletivo que simboliza o pertencimento dos cidadãos a uma determinada comunidade, sendo que todas as vozes possuem o mesmo peso, na formação das decisões públicas. Votar isoladamente pelo computador pessoal seria uma negação dessa simbologia.

Difícil discordar, nesse caso. De fato, o voto sempre foi associado a um ritual coletivo, uma experiência democrática caracterizada pelo encontro dos cidadãos em um determinado dia, para assim definirem o futuro da nação. Por outro lado, talvez esse seja um sinal dos tempos. A simplificação do ato de votar não deve ser vista como uma banalização desse ato. Essa é uma iniciativa que visa a facilitar a integração dos cidadãos com o processo político, e esse é o seu valor - poder aproximar os representantes dos representados, devolvendo-lhes o poder do povo. O eleitor não deve perder de vista os valores democráticos que norteiam a comunidade da qual ele faz parte. Esse espírito coletivo deve sempre estar presente na tomada de decisão que alcança o grupo ao qual pertence, esteja ele votando em casa ou em uma zona eleitoral. Além disso, o exemplo da utilização da Internet na campanha presidencial de Obama, em 2008, explorado no item acima, revela que o voto eletrônico é apenas um dos meios pelos quais Internet e eleição se relacionam, havendo, paralelamente, diversas formas de ampliação da participação popular no debate, inclusive tendo levado voluntários às ruas dos Estados Unidos para bater às portas das pessoas para falar sobre política.

O outro fator a postergar a implementação desse modelo de voto eletrônico off line seria, para Lulin, a exclusão digital, situação ampla e delicada que não se reduz ao acesso a computadores, mas a questões de qualificação do indivíduo e políticas públicas. Os Estados devem enfrentar o tema, possibilitando uma integração dos

659 “Est-ce un vrai risque? Pas réellement. Car on ne prétend pas convertir à Internet l'ensemble de la population, mais simplement séduire par ce moyen ceux qui, déjà praticiens du web dans les autres domaines de leur vie privée ou de leur activité professionnelle, sont aujourd'hui peu portés à participer aux scrutins et se verraient proposer là une solution pratique susceptible de les attirer vers la participation électorale.” LULIN, Elisabeth. Op. cit., p.528. 
cidadãos aos novos modelos tecnológicos que são constante e rapidamente desenvolvidos.

De qualquer forma, acompanhando Lulin, entendemos que o voto eletrônico online representa uma possibilidade de renovação da democracia, uma nova ferramenta tecnológica à disposição dos cidadãos. Como está “à disposição”, pode ser que ela nem mesmo venha a ser usada por todos. Sem dúvida, haverá aqueles que resistirão ao modelo e que se sentirão mais confortáveis, votando em uma urna, eletrônica ou não.

O valor desse modelo está na sua capacidade de transmissão abundante de informações políticas mais precisas, mais fáceis de serem acessadas, mais inclusivas, de modo que ele não deve ser desprezado como solução possível e viável ao incremento da motivação política.

\subsection{Itália}

O Movimento 5 Estrelas (M5E), ${ }^{660}$ liderado por Giuseppe Piero Grillo, efetivamente saiu do mundo virtual para o real. Beppe Grillo, como é mais conhecido esse comediante, blogueiro e político italiano, fundou, em 2009, o movimento, que participou com grande êxito das eleições gerais da Itália, ocorridas entre 24 e 25 de fevereiro de 2013. O discurso adotado foi o de uma plataforma populista que criticava a classe política tradicional, mais especificamente a política econômica de Silvio Berlusconi e Mario Monti, bem como a austeridade financeira ditada pela União Europeia.

O sucesso do movimento aparece nos números: foram garantidas 108 cadeiras na Câmara dos Deputados e 54 cadeiras no Senado, ${ }^{661}$ transformando-se na terceira maior força política italiana. Se considerado isoladamente, sem levar em conta as coligações partidárias, o Movimento 5 Estrelas tornou-se o segundo maior grupo

${ }^{660} \mathrm{O}$ nome está vinculado às cinco bandeiras do movimento: proteção das águas públicas, do meioambiente, melhoria do transporte público, conectividade e desenvolvimento. Nas eleições regionais de 2010, o M5E concorreu em cinco regiões e conquistou mais de meio milhão de votos. Disponível em: <http://www.beppegrillo.it/movimento/>. Acesso em: 7 maio 2013.

661 Segundo dados do Corriere dela Sera. Disponível em: <http://www.corriere.it/Speciali/Politica/2013/elezioni/camera/index.shtml>. Acesso em: 23 out. 2013. 
parlamentar da Câmara dos Deputados e o terceiro maior do Senado da República, o que garante a Grillo grande influência sobre o primeiro-ministro.

O movimento é apresentado como um grupo parlamentar, tanto no site da Camera dei Deputati ${ }^{662}$ quanto do Senato della Reppublica. ${ }^{663}$ No site do movimento, o que existe é um non statuto, que o define como uma non Associazione ${ }^{664}$ (art. 1), que não é um partido político e nem se entende que ele venha a se transformar em um partido, no futuro. ${ }^{665}$

Os analistas italianos têm traçado vários pontos de vista sobre essa trajetória. Para uns, Grillo obteve visibilidade por conta de seu blog, isto é, ele é fruto do dinamismo e da plataforma virtual, espaço onde ele podia dizer o que quisesse, traçando críticas ferinas e, ao mesmo tempo, cômicas.

Para outros, ${ }^{666}$ ele alcançou esse status político por combinar comédias do cotidiano com referências a escândalos políticos, insurgindo-se contra a tradicional política italiana e seus donos do poder, como um engraçado personagem do teatro. Foi assim que ele criticou as políticas do primeiro-ministro Mario Monti e apelidou o expresidente Berlusconi de anão psicótico. ${ }^{667}$

O Movimento Cinco Estrelas (M5E) conclama os cidadãos a participar ativamente da política, através de uma plataforma online - chamada Meetup, lançada em 2001 e que organiza encontros e manda convites pela Internet -, que permite a discussão e votação sobre temáticas de interesse público. O blog também é um local de formação de listas cívicas, que são as indicações dos candidatos do M5E para concorrer

\footnotetext{
662 Disponível em: <http://www.camera.it/leg17/46>. Acesso em: 05 jan. 2013.

663 Disponível em: <http://www.senato.it/leg/17/BGT/Schede_v3/Gruppi/Grp.html>. Acesso em: 05 jan. 2013.

664 Disponível em: <https://s3-eu-west-1.amazonaws.com/materiali-bg/Regolamento-Movimento-5Stelle.pdf>. Acesso em: 05 jan. 2013.

665 Uma das frases de Grillo lembradas por Bordignon e Ceccarini em seu artigo é: “The political parties are dead. Citizens need to detach themselves from the dead while they are still on time.”

666 Citamos Dario Fo, prêmio Nobel de Literatura, que apoiou Grillo e o comparou a um menestrel. Disponível em: <http://outraspalavras.net/posts/dario-fo-por-que-beppe-grillo-e-tao-importante/>. Acesso em: 13 out. 2013.

667 Ver o blog de Grillo para mais exemplos: www.beppegrillo.it.
} 
às eleições da Câmara, Senado, Conselhos Regionais e Municipais, em um exemplo evidente de e-democracia.

Atualmente, o blog de Grillo é o sétimo mais acessado do mundo e seus líderes propõem uma revolução cultural e política, na Itália.

Segundo análise de Serena Danna, de The Guardian, ${ }^{668}$ o uso que Grillo fez de seu blog e de outras mídias difere muito da estratégia usada por Obama. O presidente norte-americano não esperou que o eleitorado viesse até ele; ele foi até seus eleitores e conseguiu extrair o melhor de cada plataforma da Internet para conquistar seus votos e doações. O escopo de sua campanha foi a aproximação com o público, a interação direta com os eleitores, e toda a atenção era voltada para eles. Seu sucesso foi ter criado em cada um a ilusão de que eles eram parte crucial da campanha, só eles poderiam fazer a diferença.

A campanha do M5E é o oposto. Sua estratégia online seguiu a cartilha de um partido tradicional. Ao invés de valorizar o debate político, respondendo às críticas com ideias novas para melhorar as instituições italianas ou reduzir a corrupção política, o M5E mantinha sua postura acusatória sem um foco claro, podia atingir a qualquer um, deixando de lado a transparência de suas propostas e valorizando piadas políticas.

O tão divulgado uso do “Meetup” provou-se sem utilidade para o movimento. Primeiro, porque não buscou marcar encontros para promover debates entre os cidadãos, estimulando a participação em nível local, o que é o objetivo da ferramenta. Ela acabou sendo utilizada para fazer pesquisas de opinião ou ajudar na seleção de temas, textos e artigos que mais interessavam aos eleitores. Observamos que a Internet é uma ferramenta que tem mostrado seu potencial de interação política, e é essa capacidade que deve ser explorada. Entendemos que o uso proposto pelo líder do movimento foi limitado e até mesmo oportunista.

Assim, conclui Dana que a visibilidade conquistada por Grillo e seu movimento resulta apenas das ácidas críticas que ele fazia aos políticos italianos e aos

668 Disponível em: <http://www.theguardian.com/commentisfree/2013/mar/08/beppe-grillo-successitaly>. Acesso em: 8 jul. 2013. 
poderosos grupos industriais, atraindo tanto a classe trabalhadora decepcionada com a política econômica do país, quanto os empresários cansados da burocracia e dos altos impostos. Foi um movimento contra a política - pode ser a política tradicional, porém, não deixa de ser política - o que, no fundo, não melhora a democracia.

Bordignon e Ceccarini ${ }^{669}$ propõem uma interpretação dessa batalha travada entre Grillo, o sistema político e os meios de comunicação. Conforme os autores, o discurso de Grillo contra a política remonta à crise presenciada pelo país quando da transição da primeira para a segunda república, uma época marcada por um movimento de indignação em relação às práticas da classe política, seus privilégios e contra uma política econômica mundial que muito prejudicou o país. A crítica, obviamente, era extensiva ao parlamento e ao sistema político, o qual prevê que os partidos escolham seus candidatos, o que, para o movimento, não representava uma escolha legítima. A falta de transparência de financiamento público dos partidos também fazia parte dos temas levantados pelo movimento de então.

Todas essas críticas corrosivas ao governo, composto por Berlusconi, um dos proprietários do conglomerado televisivo italiano Mediaset, fizeram com que Grillo se voltasse para a Internet. Assim, Grillo desenvolveu seu blog, que é a plataforma política do movimento. ${ }^{670}$ Em seguida, propôs referendos sugerindo a extinção do fundo público para os jornais e a revogação de leis que regulassem a transmissão de rádio e televisão.

Ao obter reconhecimento popular, todavia, o discurso de Grillo ganhou ares populistas, com ataques à inexperiência e incompetência dos políticos, uma crítica genérica, feita a todos os políticos, todos considerados iguais. Posicionou-se, ainda, contra as elites, usando termos ofensivos para se referir aos donos do poder, mas sem apresentar propostas que mudassem a conjuntura política e social. Seu discurso apenas visava a atingir a classe privilegiada, empresários e políticos, sem distinção. O comediante e blogueiro assumiu o papel de líder carismático que sabe usar técnicas

669 BORDIGNON, Fabio; CECCARINI, Luigi. Five stars and a cricket. Beppe Grillo shakes Italian politics. South European Society and Politics, Londres, 2013. Disponível em: <http://www.tandfonline.com/doi/pdf/10.1080/13608746.2013.775720>. Acesso em: 14 set. 2013.

670 "We are like David and Goliah. We only have the web." Frase dita por Grillo em um de seus discursos. In: BORDIGNON, Fabio; CECCARINI, Luigi. Op. cit. 
discursivas para atrair o público e que sabe usar sua história e seu passado para se aproximar das mazelas do povo. ${ }^{671}$

Seguindo um comportamento elitista, Grillo se tornou o dono do movimento, administrando-o de cima para baixo e expulsando os membros que não concordavam com suas ordens e atitudes. Beppe Grillo é o único proprietário do logo do movimento, registrado em seu nome, como estatui o artigo $3^{\circ}$ do não estatuto do M5E.

Outro indicativo do comportamento elitista de Grillo por nós observado é a própria página do movimento, que é dependente do seu blog pessoal: $<$ http://www.beppegrillo.it/movimento/>. Ademais, é interessante observar que o logo do movimento contém o endereço eletrônico do blog pessoal de Grillo, que coincide com o seu nome (beppegrillo.it). Como se vê, Michels e sua teoria da oligarquização do poder, explorada no Capítulo 2, estão muito presentes. A imagem a seguir permite uma melhor compreensão do argumento aqui desenvolvido.

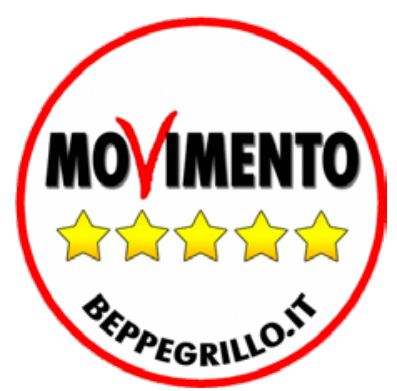

Ilustração 1. Logo do Movimento 5 Estrelas

Bordignon e Ceccarini, portanto, corroboram a análise feita por Serena Danna, de The Guardian. Beppe Grillo surge no cenário político em um momento de crise, de desemprego em alta, de um governo tecnocrático, conduzido por Monti e Berlusconi, o

671 Bordignon e Ceccarini traçam o seguinte perfil do líder Grillo: "The leader`s personal life story is always presente, implicitly or explicitly, in his speeches. Like all political leaders, he uses his background as an outsider as an asset to be exploited on the political Market: the misfortunes of a person unnacceptable to the powers-that-be, excluded from the media, and, for this reason, in position of having to reinvente his carrer. [...] His verbal and non-verbal language, his style and even his body serve to reinforce the message. The shouts, the wide-open eyes and the sweat on his brow in the shows and meeting suggest the indignation, exasperation and suffering of the citizen in the face of a degenerated system.” BORDIGNON, Fabio; CECCARINI, Luigi. Five stars and a cricket. Beppe Grillo shakes Italian politics. South European Society and Politics, Londres, 2013. Disponível em: <http://www.tandfonline.com/doi/pdf/10.1080/13608746.2013.775720>. Acesso em: 14 set. 2013. 
qual elevou o gasto público, enfraqueceu a imagem dos partidos políticos e coligações, não mostrou melhoras no sistema educacional ou social, e que é frequentemente lembrado pela má administração e corrupção. Esse cenário favoreceu o discurso populista de Grillo, que soube chamar a atenção dos cidadãos decepcionados com as instituições políticas. A trajetória atual de Grillo sugere uma continuidade das políticas do passado, no qual o partido é identificado pelo seu líder, usa a mídia para manter a alienação política e impõe uma organização partidária interna com pouca democracia, muita burocracia e hierarquias bem definidas.

Isso tem sido confirmado nos Municípios que estão sendo comandados pelo M5E. As propostas possuem um discurso contra a política; a incompetência técnica é velada pelo carisma do representante; o partido político é visto como uma empresa que vende um produto ao consumidor; o debate é centralizado pelo estilo verborrágico do líder, com tendência a virar um monólogo; ênfase na deliberação de cima para baixo.

Entendemos que o M5E tinha uma grande chance de revelar a potencialidade da Internet para o debate político, aprimorando a relação entre partidos, cidadãos e política. Infelizmente, parece que o movimento saiu da rota democrática. Independentemente da direção que o movimento tenha tomado, é forçoso reconhecer sua contribuição para mostrar a força de mobilização que a Internet oferece no sentido de desafiar a forma tradicional de fazer política, colocando em questão velhos hábitos com os quais os eleitores não concordam e contra os quais se insurgem, embora, nesse caso específico, seja possível compreender que o líder do movimento acabou por adotar, em grande medida, muitas das estratégias dos políticos contra os quais o movimento se insurgia.

Nadia Urbinatti ${ }^{672}$ argumenta que nós saímos da democracia de partido para a democracia plebiscitária, e que esse plebiscitarianismo é o da audience, um ator não coletivo no espaço privado da domesticidade. Urbinatti defende que o declínio do partido é o declínio das suas funções. Antes, ele era um corpo intermediário da democracia representativa que desempenhava funções de limitação de poder. Daí ele deixa de ser esse intermediário e se transforma no corpo oligárquico que ocupa

672 URBINATI, Nadia. Da democracia dos partidos ao plebiscito da audience. São Paulo, Lua Nova, Vol. 03, n. 05, jan./jun, 2013, p. 85-105. 
diretamente o poder, para atender a seus interesses. E, agora, surgem os partidos dos especialistas da comunicação: é a democracia da audience, o governo da mídia; e os cidadãos só querem olhar, não querem reivindicar a ação. No caso que ora analisamos, parece-nos que, ao final, os eleitores, embora talvez não tenham reivindicado uma determinada ação, demonstraram claramente o que eles não queriam.

Analisando a situação de Berlusconi, no cenário político italiano, Urbinatti ressalta o desafio lançado pelo telepopulismo ao sistema de partidos tradicionais. Assim se posiciona:

Na Itália, país em que o telepopulismo lançou um desafio radical ao sistema de partidos tradicionais, S. Berlusconi conseguiu conquistar uma maioria estável apenas quando criou seu próprio partido, promovendo uma forte identidade ideológica (até mais marcada que a dos velhos partidos) e dando a seus eleitores a certeza de pertencer a um partido. ${ }^{673}$

A autora prossegue no seu argumento, defendendo que essa democracia da audience parece mais fluida, livre e aberta, mas possui um sistema hierarquizado, rígido e padronizado, porém, “[...] agora o elemento unificador é, diretamente, a pessoa do líder e, indiretamente, o poder subliminar dos meios de comunicação de massa e dos técnicos que o usam.”

Voltando ao nosso argumento central em relação a este caso, parece-nos inegável a mensagem enviada pelos eleitores italianos aos políticos tradicionalmente no poder de que uma grande mudança era desejada. Por outro lado, o que se verificou foi que o movimento, surgido como uma alternativa aos partidos tradicionais, foi liderado por uma pessoa que acabou por usar a Internet de modo bastante semelhante à forma como os seus opositores sempre empregaram os meios de comunicação. Levando o argumento ao extremo, é possível entender que Grillo está para a internet assim como Berlusconi está para a televisão. Ambos procuram promover uma forte identidade ideológica. Contudo, enquanto Berlusconi busca dar a seus eleitores a certeza de pertencer a um partido, Grillo procura dar aos participantes do movimento a certeza de pertencer a um não partido. Não se pode desprezar, todavia, o argumento levantado no

673 Essa relação entre os eleitores de Berlusconi e o partido dele nos pareceu semelhante à ilusão, nas palavras de Danna, provocada nos eleitores de Obama, conquistados pela Internet, de que eles eram parte crucial da campanha e que somente eles poderiam fazer a diferença. 
item anterior, no sentido de que a utilização da Internet está aberta a todos, o que representa uma diferença fundamental entre a Internet e a televisão.

Somente os próximos acontecimentos relacionados a esse fenômeno italiano poderão nos dar uma exata compreensão do comportamento dos candidatos do movimento no poder. Com o resultado das eleições parlamentares italianas de 2013, o movimento passa da condição de crítico sem representação no parlamento para a condição, também, de alvo de críticas. ${ }^{674}$ Trata-se, sem dúvida, de importante agenda de pesquisa para o futuro.

Diante do caso italiano, entendemos que a mesma Internet que propiciou a grande mobilização do povo italiano por uma mudança pode ser empregada, igualmente, como instrumento de manipulação.

\subsection{Considerações gerais sobre os casos selecionados}

Conclui-se que não há um modelo universal para a organização eleitoral. Diversos países adotam diferentes modelos de organização e processo eleitoral, utilizando a solução que pensaram ser a mais adequada à sua realidade, tradição, história e diversidade cultural. Não se está propondo a vinculação obrigatória a nenhum modelo. Entretanto, na busca por um aperfeiçoamento democrático, vale a pena observar outras experiências, refletir sobre elas e aproveitá-las de acordo com as necessidades brasileiras.

Do modelo norte-americano, por exemplo, fica o estímulo ao debate político por intermédio das mídias sociais e a já referida doação de pessoas físicas pela Internet (proposta sugerida no Capítulo 3). O financiamento público brasileiro, nos moldes atuais, carece de premente reformulação. Pessoas jurídicas não são cidadãos e, por óbvio, não têm legitimidade para participar do processo político eleitoral. Até por isso a Ordem dos Advogados do Brasil (OAB) ingressou, em 2011, com uma Ação Declaratória de Inconstitucionalidade contra a doação de empresas a partidos políticos e candidatos. A ADI 4.650 encontra-se no STF e quatro ministros já votaram a favor da

674 É interessante observar que Grillo não concorreu a uma vaga no parlamento. Quais seriam suas intenções? Talvez um cargo político de maior projeção? Talvez permanecer na confortável posição de crítico? Somente pesquisas futuras poderão apresentar respostas para essas instigantes questões. 
ação. ${ }^{675}$ A doação de pessoas físicas pela Internet deve ser experimentada e avaliada como alternativa mais transparente e coerente com o processo eleitoral brasileiro.

A Estônia demonstra que o voto eletrônico à distância pode funcionar. O sistema estoniano respeita o caráter secreto do voto e elaborou uma forma de acesso digital que capta o voto com assepsia, garantindo o mesmo isolamento da urna. $\mathrm{O}$ Brasil, que já é uma referência com sua urna eletrônica off line, pode se beneficiar com esse modelo, que, ademais, reduziria o alto custo que envolve a preparação para o dia do voto.

Mais premente é, ainda, a inclusão digital. O incentivo à educação, redução - e, espera-se um dia, erradicação - do analfabetismo, o acesso a tecnologias de última geração, a redução de impostos que possibilitem esse acesso, o investimento em tecnologia e ciência, a expansão de redes wi-fi por todo o país, mesmo em locais mais longínquos, a decisão política de aprovar leis tão fundamentais como o Marco Civil da Internet: todas essas questões estão relacionadas à inclusão digital, à cidadania, à democracia, e precisam ser enfrentadas com coragem e urgência.

O modelo italiano chama a atenção para o mau uso que as mídias podem ter, quando em mãos de candidatos populistas. A proposta é sempre a de reforçar o uso das ferramentas tecnológicas como um meio de reflexão e debate, aptas a promover a interação entre os indivíduos, a aproximar diferentes grupos e anseios, a reconfigurar os partidos políticos e a tornar mais transparente a relação entre Estado, governo e instituições. A Internet não deve ser usada como mais um palco para comícios virtuais de candidatos populistas, porque essa prática em nada melhora a formação da sociedade brasileira democrática.

A Internet, novo amálgama da democracia, não está, como vimos, livre dos desafios tão comuns à própria democracia. Além disso, enfrenta desafios específicos resultantes da nova forma de debate político entre as pessoas e os grupos de interesses envolvidos. É fundamental refletir sobre seus limites e potencialidades, a fim de retirar dela os melhores resultados possíveis.

675 Os ministros foram Joaquim Barbosa, Luiz Fux, Dias Toffoli e Luís Roberto Barroso. Disponível em: <http://noticias.uol.com.br/politica/ultimas-noticias/2013/12/12/tres-ministros-do-stf-votam-contradoacao-de-empresas-em-campanha-eleitoral.htm> Acesso em: 12 dez. 2013. 


\title{
CONCLUSÃO
}

\author{
Navegar é preciso
}

Todo poder emana do povo. Esse ideal que consagra o povo como titular do poder político aparece consagrado no art. $1^{\circ}$, § único da Constituição Brasileira de 1988, e assim tem sido consagrado, no Estado moderno, desde a Revolução Francesa. ${ }^{676}$

Todavia, a impossibilidade de reunir a todos em praça pública, ou a dificuldade de realização do debate com a participação de todos os membros de uma comunidade, impôs a representatividade para a tomada de decisão.

Esse exercício do poder representativo tem sido, nos termos de Ferreira Filho, ${ }^{677}$ um dos problemas mais difíceis do direito público e da ciência política, em função da distância entre representante e representado.

A representação popular decorre do princípio democrático, já que, por ele, outorgam-se poderes do povo para que alguém o exerça e possa desempenhar funções estatais. É um instrumento que viabiliza a democracia.

O Estado liberal difundiu a ideia de um mandato representativo ou livre, com uma relação de confiança entre mandante e mandatário. Assim, o representante recebe poderes do eleitor e pode decidir de forma autônoma. Entretanto, os atos do eleito estão sempre sujeitos ao controle do cidadão, que, em caso de insatisfação, pode escolher outro representante nas próximas eleições ${ }^{678}$ ou se valer dos mecanismos constitucionais

676 Como ilustra Azambuja: “[...] os revolucionários franceses de 1789 substituíram o direito divino pela soberania popular e quiseram, entre a impossibilidade da democracia direta e o horror do absolutismo monárquico, criar um governo livre, natural e espontaneamente lançaram as bases constitucionais do regime representativo”. AZAMBUJA, Darcy. Teoria Geral do Estado. 19. ed. Porto Alegre: Globo, 1980, p. 265.

677 FERREIRA FILHO, Manoel Gonçalves. Curso de direito constitucional. 19. ed. São Paulo: Saraiva, 1992, p. 72.

678 Temos o hábito de afirmar que "brasileiro não tem memória”, ou "não sabe votar”. Alguns fatos contestam essa afirmação. Em 2006, foi desvendado o "Escândalo dos Sanguessugas”, também conhecido como “máfia das ambulâncias”, um escândalo de corrupção cujo objetivo era desviar dinheiro público destinado à compra de ambulâncias. Dentre os envolvidos, temos que, “[...] dos 69 deputados citados no escândalo, 45 disputaram e reeleição e apenas 5 conseguiram voltar à Câmara. Os 40 restantes foram atingidos pela repercussão do caso e não retornaram.” Disponível em: <http://www.cspb.org.br/news/print.php?2007/08/27/ex-deputados-sanguessugas-podem-voltar-ao- 
que estão à sua disposição para mostrar que desautoriza o ato do representante, como ação direta de inconstitucionalidade por omissão, ação popular, mandado de injunção, apelo aos conselhos tutelares, além da possibilidade de manifestação pela Internet.

As eleições servem para formatar esse "governo do povo". Ao escolher seu representante, é criado um elo entre eleito e cidadão, que se traduz no partido político. Todavia, o partido, por si só, não é capaz de operacionalizar a representação. Para tanto, é necessário haver o sistema eleitoral que, por sua vez, “[...] não esgota as leis eleitorais de uma democracia”. 679

O dilema democrático das instituições está na correspondência dos anseios de quem está no poder com o interesse público, dilema que atinge frontalmente os partidos políticos, os quais recebem severas críticas ao seu modelo de atuação.

Os grupos partidários se afastam cada vez mais de uma de suas características essenciais, a de conseguir auxiliar na composição de grupos ideológicos diferenciados, a favor do bem comum. Essa fragilidade não decorre da lei eleitoral brasileira, moderna e reconhecida pela sua efetividade. É a Lei Magna que afirma as funções de controle da Justiça sobre o processo eleitoral, o que denota a importância dada pelo constituinte a esse momento.

Ao invés de zelar pelos interesses dos cidadãos, constituindo um sistema organizado de agentes políticos que atuem em conjunto com o povo, compondo um instrumento de contrapoder frente ao Estado, assiste-se a um longo processo de degeneração dessa instituição, ${ }^{680}$ marcada por acordos que levam à troca de vantagens recíprocas, distribuição ilícita de fundos públicos e acertos ilegítimos que ferem a

congresso.phtml>. Acesso em: 2 fev. 2013. Isso evidencia que brasileiro pune político corrupto nas urnas, em alguns momentos.

679 NICOLAU, Jairo Marconi. Sistemas eleitorais. 5. ed. rev. Atual. Rio de Janeiro: Editora FGV, 2004, p. 10. É preciso definir também a capacidade ativa e passiva, as leis sobre a propaganda política, obrigatoriedade ou não do voto, dentre outros temas e normas.

${ }^{680}$ Para a compreensão da evolução desse processo, indica-se a leitura da tese de doutorado de Pedro Rubens Jehá, intitulada $O$ processo de degeneração dos partidos políticos no Brasil, defendida na Faculdade de Direito da Universidade de São Paulo, em 2009. Destacamos, ainda, as pesquisas conduzidas pela FGV/SP, que retratam o índice de confiabilidade na Justiça e que apontam o descontentamento dos cidadãos em relação aos partidos políticos, vistos com o menor índice de confiabilidade dentre as demais instituições analisadas, provando que essa degradação do partido é percebida com clareza pela sociedade. 
democracia e seus princípios, distorcendo a compreensão do que é necessário para ser alcançado o legítimo poder do povo. Isso afeta sobremaneira a noção de alternância de poder, nem sempre compreendida, mas sempre necessária.

Nogueira anota essa transição em andamento no país:

Há hoje no Brasil uma inversão de tendência. Ao longo da história, o Estado e o sistema político se mostraram mais avançados do que a sociedade. Conseguiram lhe dar um norte e unificá-la, muitas vezes abusando da força, da autoridade e da ditadura. Não é mais essa a situação. A sociedade brasileira mudou, se diferenciou, ficou mais dinâmica e mais democrática, ganhou maior complexidade. Apresenta faixas enormes de miséria, de violência, de corporativismo, está carente de projetos que a unifiquem e lhe indiquem um futuro. Mas está viva, emitindo sons e sinais que não estão sendo traduzidos adequadamente pela política. ${ }^{681}$

Esses “sons e sinais” fizeram-se ver e ouvir nas ruas do país, durante as manifestações de junho de 2013. Apesar de, aparentemente, o resultado concreto ter sido apenas a redução da tarifa de ônibus, estopim do movimento, o maior saldo foi perceber que o povo ainda se revolta, deixando a propalada cordialidade de lado para se juntar em mobilizações nas ruas, dizendo que está cansado dos desmandos, da corrupção, da falta de segurança e dos abusos e conchavos políticos.

Esse cenário ilustrou a falta de diálogo democrático efetivo que tem marcado a sociedade brasileira, cuja prática política tem sido reduzida a uma lógica binária que estabelece o “nós” contra “eles”, “donos do poder” contra "sociedade”, “partidos” contra "cidadãos”, abalando a democracia, a qual se sustenta exatamente na pluralidade de visões de mundo.

O Congresso atônito, diante da maioria revoltada com os descaminhos democráticos, é um sinal de que o povo não deixou de perceber que o poder é dele. E a mobilização só foi possível por conta das redes sociais.

681 NOGUEIRA, Marco Aurélio. Mídia, democracia e hipermodernidade periférica. In: GOULART, Jefferson (Org.). Mídia e democracia. São Paulo: Annablume, 2006, p. 18. 
A dinâmica desses protestos foi organizada pela Internet em uma ação chamada smart mob, ${ }^{682}$ isto é, um movimento que tem caráter político, combinado nas redes sociais, por meio de blogs, Twitter ou Facebook, ou por $S M S^{683}$ enviado por celular como forma de comunicação e mobilização. Essas manifestações promovem uma ação específica no tempo e espaço, e o objetivo é impactar as instituições políticas, dissolvendo-se logo em seguida.

Esse é um exemplo de como a Internet pode ser usada para estimular a participação cidadã.

Os estudos sobre as potencialidades e os efeitos da relação entre democracia e novas tecnologias têm sido conduzidos desde a década de 1990. Pippa Norris, por exemplo, autora fluente no tema, afirma que a Internet produzirá alterações significativas nos sistemas políticos democráticos contemporâneos, mas sempre de uma forma a reforçar os institutos da democracia representativa. ${ }^{684}$ Seus estudos sobre o uso da Internet pelos partidos políticos na Europa enfatizam que a Internet e seus mecanismos de interação funcionam como um fórum cívico, o qual possibilita a manifestação de oposições e abre novos canais de participação ao cidadão, melhorando a qualidade da representação, ao aproximar candidatos de eleitores.

Nessa perspectiva, o uso das redes aumenta o grau de pluralismo da democracia e privilegia a liberdade de expressão e de manifestação tão fundamentais para a democracia, que se pauta no debate livre à procura da melhor tomada de decisão para o bem comum da sociedade. Ao assegurar que os temas possam ser discutidos sob todas as perspectivas, a sociedade consegue buscar um equilíbrio entre mudança e estabilidade, entre contestação e consenso.

682 Rheingold, principal teórico das smart mobs, observa que apenas as novas tecnologias conseguem engendrar ações coletivas e interações desse porte, em função de sua estrutura e rapidez de comunicação. Ressalta como característica dessa ação a falta de controle central e a formação de subunidades autônomas interconectadas ("[...] the absence of imposed centralized control, the autonomous nature of subunits, the high connectivity between the subunits”). RHEINGOLD, Howard. Smart mobs: the next social revolution. Cambridge: Basic Book, 2002, p. 178.

683 Sigla para short message system, ou, em português, “torpedo” ou mensagem por celular.

684 NORRIS, Pippa. Digital divide, civic engagement, information poverty, and the Internet worldwide. Cambridge: Cambridge University, 2001. 
O Estado assegura uma série de prerrogativas que dizem respeito às principais dimensões do ser humano, enquanto pessoa e cidadão, que possui a capacidade de influir na sociedade política para reivindicar seus direitos e, em contrapartida, exercer seus deveres. Marshall ${ }^{685}$ citava os três elementos a compor a cidadania, sendo o elemento político aquele que dá ao cidadão o direito de participar no exercício do poder político, assumindo o papel de membro de uma organização que possui autoridade política, ou como eleitor dos membros do Parlamento.

Essa concepção de cidadania foi ampliada. Exige-se seu envolvimento e participação na construção de uma democracia possível. Cidadania não se restringe há tempos ao exercício do voto, mas abarca uma concepção democrática que busca o fortalecimento da sociedade civil na construção do projeto social que melhor lhe atende. A síntese dessa trajetória é feita por Dahrendorf:

Sem dúvida, a cidadania não existe apenas a propósito donde as pessoas se situam, porém a respeito do que fazem. Trata-se de participação. E uma vez mais a dinâmica da ideia acarretou profundas mudanças nos últimos duzentos anos. Veja-se a participação política, que é o caso mais óbvio; o sufrágio foi estendido de uma estreita faixa de proprietários pagantes de impostos a todos os homens, em seguida, às mulheres, por fim a todos aqueles acima de 18 anos; a eleição, em vez de nomeação para posições de responsabilidade, tornou-se mais e mais alastrada; as possibilidades de informação e debate público multiplicaram-se pelo desenvolvimento das mídias; a educação capacitou mais gente a tomar parte efetiva na determinação de seus negócios. ${ }^{686}$

Entretanto, a participação ainda é incompleta. É preciso reiterar a importância da consciência crítica do cidadão, fortalecer sua capacidade de entendimento do contexto em que se encontra, bem como sua capacidade de emitir juízo sobre as condições da vida e da sociedade, para, com isso, obter uma conquista democrática real de espaços e direitos. Defendemos o potencial da Internet para reaquecer o espaço público, criar novas formas de vínculo comunitário e dinamizar a participação política.

685 MARSHALL, Thomas H. Op. cit. O elemento civil representado pelos direitos que garantem a liberdade individual, e o elemento social, que se refere ao direito ao bem-estar econômico, direito de participar da vida pública dentro dos padrões estabelecidos socialmente, direito à segurança.

686 DAHRENDORF, Ralf. A nova liberdade. Brasília: Universidade de Brasília, 1975, p. 44. 
Porém, antes de tudo, a Internet é um meio. O que vai ditar processos e aperfeiçoar a democracia e cidadania é o uso que as pessoas e as instituições farão da ferramenta tecnológica, extraindo melhor proveito do que ela oferece em termos concretos.

Os estudiosos destacam bons exemplos de canais de participação política pela Internet, como as consultas públicas digitais, com ênfase para o debate sobre o Marco Civil da Internet, o portal e-democracia da Câmara dos Deputados, ou, ainda, o Gabinete Digital do governo do Rio Grande do Sul, espaço virtual de diálogo entre cidadãos e poder público.

Em outros países, a prática do voto eletrônico remoto tem obtido resultados promissores, com aumento da participação dos cidadãos a todo ano, como nas eleições conduzidas na Estônia. E as eleições norte-americanas de 2008, é evidente, modelo de mobilização dos eleitores em uma campanha política, além de exemplo de doações privadas para o financiamento de campanhas conduzido pela rede mundial.

No Brasil, os candidatos e partidos vêm usando a Internet e as mídias sociais desde 2006. A cada eleição brasileira, o número de pessoas com acesso à rede aumenta. E, apesar de ser incomum o eleitor se atualizar sobre política apenas pela Internet, a cada pleito ela igualmente tem-se tornado uma ferramenta a mais de informação. Isso demonstra que, aos poucos, a Internet tem sido utilizada com fins de comunicação e informação política.

Outrossim, pesquisas apontam para o número crescente de pessoas de diferentes classes sociais com acesso à Internet e o aumento do número de celulares e smartphones no país. A ponderação de Lemos merece destaque:

A discussão sobre o acesso ao conteúdo importa muito ao Brasil, mesmo que o pais seja assolado de modo tão profundo pela exclusão digital. O acesso a computadores é pequeno, mas o acesso a outros aparelhos, como celulares e televisão, é amplo. Só os celulares já são 60 milhões. A convergência tecnológica torna esses aparelhos os próximos meios de acesso à informação e ao conteúdo. Por isso, é preciso descartar rapidamente o pensamento etapista, em que primeiro é preciso dar computadores para a população e somente depois se preocupar com a democratização do conteúdo. O conteúdo precisa ser descentralizado, aberto, e acessível desde já, para que possa ser 
acessado seja pelo computador, pelo celular, pela TV digital ou pelo rádio digital. ${ }^{687}$

Nota-se, portanto, que a utilização da Internet no processo eleitoral brasileiro ainda é incipiente, mas ganha importância a cada eleição. Nas últimas eleições para a Prefeitura da cidade de São Paulo, os candidatos privilegiaram a mobilização da militância e dos simpatizantes pela Internet.

Espera-se que os partidos passem por um processo de resgate de suas funções primárias de defesa da democracia e da educação política, pela Internet e suas mídias, transformando o padrão atual de baixa participação política da esfera civil nas democracias atuais, ampliando a mobilização e a intervenção do cidadão nos negócios públicos por meio de fóruns eletrônicos e plebiscitos on-line. ${ }^{688} \mathrm{Com}$ isso, espera-se, também, que os partidos tornem suas atividades e projetos, opiniões e posicionamentos cada vez mais transparentes, abrindo-se para o controle e fiscalização dos cidadãos e mostrando em suas páginas virtuais quanto recebem de financiamento e como o dinheiro é investido.

A tendência é que seu uso seja incrementado e que o candidato aprenda a interagir com o cidadão, e não apenas com o eleitor, durante os meses dedicados à propaganda política. As agências de publicidade e os profissionais da comunicação desenvolvem iniciativas para a comunicação política on-line entre os representantes e representados. O político, por sua vez, tem que saber fazer uso da Internet antes e depois das eleições, estabelecendo um diálogo transparente e aberto com os cidadãos. A democracia é um processo imperfeito e que tem buscado se aperfeiçoar, ao longo de sua existência. Sua maior vantagem é contar com a participação do cidadão para repensar o

687 LEMOS, Ronaldo. O creative comons e as transformações da propriedade intelectual. In: BARBOSA FILHO, André; CASTRO, Cosette; TOME, Takashi (Org.). Mídias digitais: convergência tecnológica e inclusão social. São Paulo: Paulinas, 2005, p. 265.

688 Ribeiro alertava, na década de 1980, para o seguinte fato: “Se os partidos não se reorganizarem em novos moldes permanecerão defasados diante das transformações sociais que estão demandando relacionamentos mais estimulantes com seus adeptos e simpatizantes, instaurando procedimentos integrativos em suas convivências internas, poderão começar a sofrer de progressiva rejeição em não renovando as suas atitudes, mantendo-se enclausurados os seus mecanismos deliberativos, inadvertidos de sua própria ruína.” RIBEIRO, Fávila. Constituinte e participação popular: o momento estratégico da ordenação pré-Constituinte e a emenda constitucional $n^{0}$ 25/85. São Paulo: Saraiva, 1986, p. 66. 
próprio regime político e transformá-lo de acordo com um projeto social que atenda ao bem comum. ${ }^{689}$

Sunstein nos mostra que esse percurso não é tão simples, e que a Internet ainda precisa superar a lógica binária acima mencionada. $\mathrm{O}$ autor sublinha sua preocupação com a relação de consumo que os cidadãos se acostumaram a ter com a política. A prática da sociedade capitalista em estimular o consumo - entrar em uma loja, escolher o que quer, sem pensar no processo que levou aquele objeto a ser produzido, de modo a satisfazer apenas seu desejo individual - foi replicado na política. Assim, o cidadão não se envolve no processo de negociação, nem participa efetivamente na tomada de decisão. Ele até sabe se unir para uma ação pontual - como as smart mobs - mas não aprendeu a habilidade de construir projetos consensuais. Esse cenário afeta a integração, pois as pessoas se dividem em grupos na Internet e não têm interesse em saber o que as outras pessoas pensam, ou, pior ainda, as hostilizam.

Ora, democracia é ter a liberdade de falar e se manifestar, ${ }^{690}$ mas também de ouvir. Democracia se faz ouvindo respeitosamente o argumento e a opinião do outro. É importante repensar esse cenário, no sentido de minimizar a atuação de seus elementos poluentes, sabendo usar o próprio espaço virtual para provocar interação, e não isolamento, convivência, ao invés de separação. Afinal, é importante salientar que “[...] um projeto político é democrático quando não se reduz a um conjunto de interesses particulares de um grupo, organização ou movimento. Para ser democrático deverá incorporar uma visão de mundo que tenha como horizonte o outro e o universal.”" ${ }^{291}$ Demais disso, o barulho e a agressividade que surgem no ambiente conflagrado na Internet precisam ser inibidos.

689 Brin lembra as ponderações de Jefferson sobre a necessidade de adaptação e debate: "When Thomas Jefferson prescribed a revolution every few decades, he was speaking not only politically but also about the constant need to remain flexible and adapt to changing circumstances, to innovate as needed, while at the same time staying true to those values we hold unchanging and precious. Our civilization is already a noisy one precisely because we have chosen freedom and mass sovereignty, so that citizenry itself must constantly argue out the details, instead of leaving them to some committee of sages.” BRIN, David. The transparente society. Cambridge: Basic Books, 1998, p. 10.

"La base jurídica de manifestación es algo especial y podría incluso considerarse el más reciente de los derechos fundamentales de última generación. [...] Los manifestantes se articulan a sí mismos como una parcela del ámbito político, como una espécie de 'preconfiguración' de la voluntad política.” HÄBERLE, Peter. Pluralismo y constitución: estudios de teoría constitucional de la sociedad abierta. Madrid: Tecnos, 2002, p. 155.

691 GOHN, Maria da Glória. O protagonismo da sociedade civil: movimentos sociais, ONGs e redes solidárias. 2. ed. São Paulo: Cortez, 2008, p. 36-37. 
A democracia é o reino da liberdade, um espaço de busca de consensos para que possa ser alcançado o bem comum. Possui rumo incerto e indefinido, porque o futuro da democracia só pode ser escrito pelo povo, o único com o legítimo poder para fazê-lo. Poder dessa ordem não pode ser desperdiçado. Hodiernamente, o povo conta com um instrumento social e político capaz de promover protestos, mobilizações e campanhas de opinião pública, uma arena contemporânea que pode incentivar a participação e que é capaz de dar voz a todas as diferenças, compondo a várias mãos seja no Facebook, Twitter, YouTube, seja em qualquer outro meio de interação que surja - a história democrática de todos nós. Navegar pelas páginas da Internet torna-se, nesse sentido, cada vez mais fundamental para o fortalecimento da cidadania e do ambiente democrático. 


\section{REFERÊNCIAS}

ALDÉ, Alessandra; BORGES, Juliano. Ataques na Internet nas eleições de 2002 (ou como os sites pautaram a cobertura da imprensa). In: ENCONTRO ANUAL DA ANPOCS, XXVIII, 2004. Seminário Temático 09: “Democracia, comunicação política e eleições”. Anais... Caxambu, MG, 2004.

ALMAZÁN, Jaime. Derecho a la información y derechos humanos. Disponível em: <http://www.itaipem,org.mx/work/resources/LocalContent/379/3/X\%20mesa\%20Derec ho\%20info\%20jaime\%20almazan\%20ok.doc>. Acesso em: 31 mai. 2012.

ALMEIDA, Fernando Dias Menezes. Estatuto do candidato: reflexões sobre a "Lei Ficha Limpa”. In: CAGGIANO, Monica Herman S. (Coord.); MESSA, Ana Flávia; ALMEIDA, Fernando D. M. de (Org.). Direito eleitoral em debate: estudos em homenagem a Cláudio Lembo. São Paulo: Saraiva, 2013.

ALMOND, Gabriel; VERBA, Sidney. The civic culture. Political atitudes and democracy in five nations. USA: Little Brown and Company, 1965.

ALONSO, Ângela. As teorias dos movimentos sociais: um balanço do debate. Lua Nova, São Paulo, nº 76, p. 49-86, jan./jun. 2009.

ALVAREZ, R.; HALL, T.; TRECHSEL A. Internet Voting in Comparative Perspective: The Case of Estonia. Political Science and Politics, Cambridge, v. 42, p. 497-505, 2009.

ALVIM, Francisco. Com ansiedade. In: . Poemas. São Paulo: Cosac \& Naify, 2004.

AMADO, Gilberto. Eleição e representação. 3. ed. Rio de Janeiro: Sá Cavalcante, 1969.

ANDRADE, Carlos Drummond de. A rosa do povo. São Paulo: Companhia das Letras, 2012.

ANDRADE, Gentil. Pensamentos e reflexões de Machado de Assis. Rio de Janeiro: Civilização Brasileira, 1990.

ARAÚJO, Luiz Alberto David; NUNES JÚNIOR, Vidal Serrano. Curso de direito constitucional. 6. ed. São Paulo: Saraiva, 2002.

ARENDT, Hannah. Origens do totalitarismo: antissemitismo, imperialismo e totalitarismo. Trad. Roberto Raposo. São Paulo: Companhia das Letras, 2009.

. Verdade e política. In: Entre o passado e o futuro. 3. ed. São Paulo:

Perspectiva, 1992, pp. 282-325.

ARISTÓTELES. A política. São Paulo: Martins Fontes, 1998. 
. Ética a Nicômaco. Trad. Julán Marias. Madri: Centro de Estudios

Constitucionales, 1999.

ASSIS BRASIL, Joaquim Francisco. A democracia representativa na república antologia. Brasília: Senado Federal, 1998.

ASSUNÇÃO, Monica M. T. Carlos Lacerda: demolidor de presidentes e construtor de um novo Estado. Tese (Doutorado em Ciências Humanas e Filosofia) - Universidade Federal Fluminense, Rio de Janeiro, 2011.

ÁVILA, Humberto. Teoria dos princípios - da definição à aplicação dos princípios jurídicos. 10. ed. São Paulo: Malheiros, 2009.

AVRITZER, L. (Org.). Sociedade civil e democratização. Belo Horizonte: Del Rey, 1994.

BARRETO, Lauro. Reeleição e continuísmo. Rio de Janeiro: Lumen Juris, 1998.

. Manual de propaganda eleitoral. Bauru: Edipro, 2000.

BARROS, Sérgio Resende de. O voto distrital. Disponível em:

$<$ http://www.srbarros.com.br/pt/o-voto-distrital.cont>. Acesso em: 07 jul. 2013.

BARROS FILHO, Clóvis; COUTINHO, Maurício; SAFATLE, Vladimir. Os usos das novas mídias na campanha presidencial de 2006. In: LIMA, Venício Artur de. A mídia nas eleições 2006. São Paulo: Fundação Perseu Abramo, 2007.

BASTOS, Celso Ribeiro. Comentários à Constituição do Brasil. São Paulo: Saraiva, 2004.

BEÇAK, Rubens. Instrumentos de democracia participativa. Revista de Ciências Jurídicas, Maringá, v. 6, n. 2, p. 143-153, 2008. Disponível em:

<http://www.periodicos.uem.br/ojs/index.php/RevCiencJurid/article/view/10942>.

Acesso em: 2 set. 2012.

. Sobre a origem das normas constitucionais: a identificação do campo-ético moral e sua relação com o Direito. In: BEÇAK, R. e VELASCO, Ignácio M. P. (Org.). O Direito e o futuro da pessoa: estudos em homenagem ao prof. Antonio J. de Azevedo. São Paulo: Atlas, 2011, p. 16-28.

BERCOVICI, Gilberto. A origem do sistema proporcional no Brasil. Estudos eleitorais, Brasília, v. 1, n. 1, p. 51-64, 1997.

BERLIN, Isaiah. Four essays on liberty. Nova York/Oxford: Oxford University Press, 1969.

BIMBER, B.; DAVIS, R. Campaining on-line: the Internet in the U.S. elections. New York: Oxford University, 2003. 
BOBBIO, Norberto. As teorias das formas de governo. Trad. Sérgio Bath. 9. ed. Brasília: Editora UnB, 1997.

. Verbete: Pluralismo. In: BOBBIO, Norberto; MATTEUCI, Nicola;

PASQUINO, Gianfranco. Dicionário de Política. Brasília: UnB, 1986.

. O futuro da democracia. Trad. de Marco Aurélio Nogueira. 8. ed. São Paulo:

Paz e Terra, 2002.

BORDIGNON, Fabio; CECCARINI, Luigi. Five stars and a cricket. Beppe Grillo shakes Italian politics. South European Society and Politics, Londres, 2013. Disponível em: <http://www.tandfonline.com/doi/pdf/10.1080/13608746.2013.775720>. Acesso em: 14 set. 2013.

BORJA, Rodrigo. Derecho político y constitucional. 2. ed. México D.F.: Fondo de Cultura Económica, 1991.

BOURDIEU, Pierre. Sobre a televisão. Trad. Maria Lúcia Machado. Rio de Janeiro: Zahar, 1997.

BOVERO, Michelangelo. Contra o governo dos piores: uma gramática da democracia. Trad. Daniela B. Versiani. Rio de Janeiro: Campus, 2002.

BRAGA, Maria do Socorro Sousa. Organizações partidárias e seleção de candidatos no estado de São Paulo. Opinião. Publica, Campinas , v. 14, n. 2, nov. 2008 . Disponível em: <http://www.scielo.br/scielo.php?script=sci_arttext\&pid=S0104-

62762008000200008\&lng=en\&nrm=iso>. Acesso em: 24 nov. 2013.

BRAGA, Sérgio Soares; FRANÇA, Andressa S. T.; NICOLÁS, Maria Alejandra. Os partidos políticos e a Internet - uma avaliação dos websites dos partidos políticos do Brasil. Revista de Sociologia e Política, Curitiba, v. 17, nº 34, p. 183-208, out. 2009.

BRAGA, Sérgio; NICOLÁS, Maria A.; BECHER, André R. Elites políticas e NTICS: uma análise do uso da Internet pelos candidatos aos governos estaduais e ao senado federal nas eleições brasileiras de outubro de 2010. In: ENCONTRO ANUAL DA ANPOCS, 35, 2011. Anais... Caxambu, 2011. Disponível em:

<http://www.anpocs.org.br/portal/35_encontro_gt/GT01/Nicolas_Becher_Braga.pdf>. Acesso em: 2 set. 2013.

BRASIL. Constituição da República Federativa do Brasil. 5 out. 1988. Disponível em: <www.planalto.gov.br>. Acesso em: 20 out. 2012.

BRASIL. Lei complementar n. 64, de 18 de maio de 1990. Estabelece, de acordo com o art. 14, $\S 9^{\circ}$ da Constituição Federal, casos de inelegibilidade. Disponível em: <www.planalto.gov.br>. Acesso em: 20 out. 2012.

BRASIL. Lei complementar n. 135, de 4 de junho de 2010. Altera a Lei Complementar n. 64 de 18 de maio de 1990, que estabelece casos de inelegibilidade, para incluir hipóteses de inelegibilidade que visam a proteger a probidade administrativa e a 
moralidade no exercício do mandato. Disponível em: <www.planalto.gov.br>. Acesso em: 20 out. 2012.

BRASIL. Lei federal n. 4.737, de 15 de julho de 1965. Código Eleitoral. Disponível em: www.camara.leg.br. Acesso em: 20 out. 2012.

BRASIL. Lei federal n. 9.096, de 19 de setembro de 1995. Dispõe sobre partidos políticos. Disponível em: <www.planalto.gov.br>. Acesso em: 20 out. 2012.

BRASIL. Lei federal n. 9.504, de 30 de setembro de 1997. Estabelece normas para as eleições. Disponível em: <www.planalto.gov.br>. Acesso em: 20 out. 2012.

BRASIL. Lei federal n. 12.034, de 29 de setembro de 2009. Altera as Leis n. 9.096 de 19de setembro de 1995 - Lei dos Partidos Políticos, 9.504, de 30 de setembro de 1997, que estabelece normas para as eleições, e 4.737, de 15 de julho de 1965 - Código Eleitoral. Disponível em: <www.planalto.gov.br>. Acesso em: 20 out. 2012.

BRASIL. Lei federal $n$. 12.527, de 18 de novembro de 2011. Regula o acesso a informações previsto no inciso XXXIII do art. $5^{\circ}$, no inciso II do $\S 3^{\circ}$ do art. 27 e no $\S$ $2^{\circ}$ do art. 216 da Constituição Federal. Disponível em: <www.planalto.gov.br>. Acesso em: 20 out. 2012.

BRASIL. Projeto de lei $n$. 2126/2011. Estabelece princípios, garantias, direitos e deveres para o uso da Internet no Brasil. Disponível em: <www.camara.gov.br>. Acesso em: 13 jul.2013.

BRASIL. STJ - Recurso Especial n 1192208 MG 2010/0079120-5. Relator: Ministra NANCY ANDRIGHI. Brasília. Data de Publicação: 02/08/2012. Disponível em: $<$ www.stj.gov.br>. Acesso em: 13 jul. 2013.

BRASIL. TRE-CE- Recurso Eleitoral n ${ }^{\circ}$ 14512. Juiz Haroldo Correia Máximo. Fortaleza. Publicado em 9/1/2009. Disponível em: <www.jusbrasil.com.br.>Acesso em: 13 jul. 2013.

BRASIL. TRE - MS. Recurso Eleitoral n 259-67.2010.6.12.022. Juiz Renato Toniasso. Campo Grande. Publicado em 25/09/2012. Disponível em: <www.jusbrasil.com.br.>Acesso em: 13 jul. 2013.

BRASIL. TRE-MT. Recurso Eleitoral n 40827. Juiz Relator Sebastião de Arruda. Cuiabá. Publicado no dia 25/09/2012. Disponível em <www.jusbrasil.com.br.>Acesso em: 13 jul. 2013.

BRASIL. TRE-PB. Recurso Eleitoral ${ }^{\circ}$ 18592. Juiz Relator: TERCIO CHAVES DE MOURA. João Pessoa. Publicado em: 23/10/2012. Disponível em <www.jusbrasil.com.br.>Acesso em: 13 jul. 2013.

BRASIL. TRE-PE. Recurso Eleitoral $n^{\circ}$ 7-77.2012.6.17.0005. Juiz Relator Luiz Alberto G. de Faria. Recife. Publicado em 08/08/2012. Disponível em: <www.tre-pe.jus.br>. Acesso em: 29 set. 2013. 
BRITO, Antônio Carlos de (CACASO). Lar doce lar. In: Lero-lero. Rio de Janeiro: 7 Letras; São Paulo: Cosac \& Naify, 2002.

BURDEAU, Georges. Direito constitucional. Trad. Carlos Souza. Barueri, SP: Manole, 2005.

BURKE, Peter; BRIGGS, Asa. Uma história social da mídia: de Gutenberg à Internet. Tradução Maria Carmelita Pádua Dias. 2. ed. ver. e ampl. Rio de Janeiro: Jorge Zahar, 2006.

CAGGIANO, Monica Herman Salem. A fenomenologia dos trânsfugas no cenário político-eleitoral brasileiro. In: CAGGIANO, Monica Herman S. (Org.). O voto nas Américas. São Paulo: CEPES, 2008.

Democracia X Constitucionalismo. Um navio à deriva? Disponível em: <http://www.cepes.org.br>. Acesso em: 22 jun. 2012.

Direito eleitoral e direito parlamentar. Barueri: Manole, 2004.

Do direito de sufrágio ativo. Do corpo Eleitoral. In: CAGGIANO, Monica Herman Salem (Coord.); MESSA, Ana Flávia; ALMEIDA, Fernando Dias Menezes de. Direito eleitoral em debate: estudos em homenagem a Cláudio Lembo. São Paulo: Saraiva, 2013.

. Eleições municipais de 1996, com ênfase para o quadro de São Paulo. Revista da Faculdade de Direito Universidade de São Paulo, São Paulo, Ano 1, n. 1, v. 91, p. 333-361, 1996.

. Finanças Partidárias. Brasília: Senado Federal, 1983.

O cidadão-eleitor, jogador com veto no processo eleitoral democrático Aspectos polêmicos e peculiares do cenário brasileiro. Eleições gerais2010. In: INSTITUTO VICTOR NUNES LEAL (Org.). A contemporaneidade do pensamento de Victor Nunes Leal. São Paulo: Saraiva, 2013, p. 288-289.

Oposição na política. São Paulo: Angelotti, 1995.

. Sistemas Eleitorais x Representação Política. 1987. Tese (Doutorado em Direito) - Faculdade de Direito da Universidade de São Paulo. São Paulo, 1987.

CÂNDIDO, Joel J. Direito eleitoral brasileiro. 12. ed. Bauru, SP: Edipro, 2006.

CANOTILHO, J.J. Gomes. Direito constitucional. 6. ed. Coimbra: Almedina, 1993.

CARVALHO, José Murilo de. Cidadania no Brasil: o longo caminho. 10. ed. Rio de Janeiro: Civilização Brasileira, 2008.

CASTELLS, Manuel. A sociedade em rede. A era da informação: economia, sociedade e cultura, v. 1. Trad. Roneide Venancio Majer. 6. ed. São Paulo: Paz e Terra, 2012. 
. Não é crise. É que não te quero mais. Disponível em:

$<$ http://outraspalavras.net/posts/nao-e-crise-e-que-nao-te-quero-mais/>. Acesso em: 08 ago. 2011.

. A Galáxia Internet: reflexões sobre a Internet, os negócios e a sociedade. Trad. Maria Luiza X. de A. Borges. Rio de Janeiro: Jorge Zahar, 2003. Terra, 2001.

O poder da identidade. Trad. Klauss Brandini Gerhardt. Rio de Janeiro: Paz e A era da informação: economia, sociedade e cultura. Vol. II - O poder da identidade. Trad. Klauss Brandini Gerhardt. São Paulo: Paz e Terra, 2000.

CHACON, Vamireh. História dos partidos brasileiros: discurso e práxis dos seus programas. 2. ed. Brasília: Ed. Universidade de Brasília, 1985.

CITADINI, Antonio Roque. Código eleitoral anotado e comentado. 2. ed. São Paulo: Max Limonad, 1985.

CLÈVE, Clèmerson Merlin. Direito constitucional, novos paradigmas, constituição global e processos de integração. In: BONAVIDES, Paulo; LIMA, F. G. M.; BEDÊ, Fayga S. (Coord.) Constituição e democracia: estudos e homenagem ao Prof. J.J. Canotilho. São Paulo: Malheiros, 2006.

. Fidelidade partidária - estudo de caso. Curitiba: Juruá, 1998.

. Liberdade de expressão, de informação e propaganda comercial. Curitiba, Revista Crítica Jurídica, n. 24, p. 258-259, jan./dez. 2005.

COHEN, Jean L. Strategy or identity: new theoretical paradigms and contemporary social movements. Social research, New York, v. 52, nº 4, p. 663-716, 1985.

; ARATO, Andrew. Civil society and political theory. Massachusetts: The MIT Press, 1982.

CONEGLIAN, Olivar. Propaganda eleitoral - de acordo com o Código Eleitoral e com a Lei nº 9.504/97. 6. ed. Curitiba: Juruá, 2004.

CONSTANT, Benjamin. Liberdade dos antigos x liberdade dos modernos. Trad. António de Araújo. Coimbra: Tenacitas, 1983.

. Mélanges de littérature et de politique. Disponível em :

<http://gallica.bnf.fr/ark:/12148/bpt6k1113078.>. Acesso em: 24 dez. 2013.

COOK, Thimothy. Governing with the News: the News media as a policial institution. Chicago: The University Press, 1998.

CÔRTES, Lara Barbosa Quadros. Estado Federal e igualdade na educação básica pública. 2013. 269 f. Tese (Doutorado em Direito) - Faculdade de Direito, Universidade de São Paulo, São Paulo, 2013. 
COSTA, Márcia Mello (Org.) De Liberal. Um olhar sobre ética e cidadania. São Paulo: Mackenzie, 2002.

COSTA, Pietro. Poucos, todos, muitos: lições de história da democracia. Trad. Luiz Fritolo. Curitiba, UFPR, 2012.

COSTA, S. A democracia e a dinâmica da esfera pública. Lua Nova, São Paulo, n. 36, p. 55-65, 1995.

COUTINHO, C.N. Crítica e utopia em Rousseau. Lua Nova, São Paulo, n. 38, p. 23-27, 1996.

. Democracia e socialismo. São Paulo: Cortez, 1992.

COUTINHO, Marcelo; SAFATLE, Vladimir. A Internet e as eleições municipais em 2008: o uso dos sítios eletrônicos de comunidades na eleição paulistana. Revista de Sociologia e Política, Curitiba, vol. 17, n. 34, 115-128, out. 2009.

CRUZ, Paulo Márcio. Repensar a democracia. Revista da Faculdade de Direito da UFG, Goiânia, vol. 33, n. 1, p. 115-128, jan./jun. 2009.

DAHL, Robert. Polyarchy: participation and opposition. New Haven: Yale University, 1971.

Sobre a democracia. Brasília: UnB, 2001.

DAVENPORT, Thomas. Saving its soul: human-centered information management. Harvard Business Review, Harvard, v. 72, n. 2, p. 119-131, mar./apr. 1994.

DIPPEL, Horst. História do constitucionalismo moderno. Trad. Antônio M. Hespanha e Cristina N. da Silva. Lisboa: Fundação Calouste Gulbenkian, 2007.

DIZARD, Wilson. A nova mídia: a comunicação de massa na era da informação. 2. ed. Rio de Janeiro: Jorge Zahar, 2000.

DOWNS, Anthony. Up and down with ecology - the 'Issue-Attention Cycle'. The Public Interest, Boca Raton/Flórida, n. 28, p. 38-50, 1972.

DUARTE, Jorge. Assessoria de imprensa e relacionamento com a mídia: teoria e técnica. São Paulo: Atlas, 2002.

DUARTE, Maurício. O rei do tijolão. São Paulo, Afinal, o que é qualidade de vida? Revista da Cultura, ed. 77, p. 61, dez. 2013.

DURIGUETTO, Maria Lúcia. Sociedade civil e democracia: um debate necessário. São Paulo: Cortez, 2007.

DUVERGER, Maurice. Institutions politiques et droit constitutionnel. Vol. 1 - Les grands systèmes politques. 13. ed. Paris: Presses Universitaires de France, 1973. 
1970.

Os partidos políticos. Trad. Cristiano Monteiro Oiticica. Rio de Janeiro: Zahar,

FALCÃO, Joaquim. Democracia, direito e terceiro setor. Rio de Janeiro: Editora FGV, 2004.

FARIA, José Eduardo. Entre a rigidez e a mudança. Revista Brasileira de Direito Constitucional, São Paulo, n. 2, p. 204, jul./dez. 2003.

FERRARI, Pollyana. A força da mídia social. São Paulo: Factash, 2010.

FERREIRA, Manoel Rodrigues. A evolução do sistema eleitoral brasileiro. Brasília: Senado Federal, 2001.

FERREIRA FILHO, Manoel Gonçalves. A democracia possível. São Paulo: Saraiva, 1972.

. Curso de direito constitucional. 36. ed. São Paulo: Saraiva, 2010.

O poder constituinte. 5. ed. São Paulo: Saraiva, 2007.

. Os partidos políticos nas constituições democráticas: o estatuto constitucional dos partidos políticos no Brasil, na Itália, na Alemanha e na França. Revista Brasileira de Estudos Políticos, Belo Horizonte,1966.

Sete vezes democracia. São Paulo: Convívio, 1977.

FLEINER-GERSTER, Thomas. Teoria geral do Estado. Trad. Marlene Holzhausen.

São Paulo: Martins Fontes, 2006.

FOLETTO, Leonardo. Blogosfera x Campo jornalístico: aproximação e consequências.

São Paulo: Momento, 2009.

FREITAS, Maria Esther. Cultura organizacional: identidade, sedução e carisma. Rio de Janeiro: Editora FGV, 1999.

FREYRE, Gilberto. Casa grande \& senzala: formação da família brasileira sob o regime de economia patriarcal. Rio de Janeiro: Maia \& Schmidt, 1953.

GARAPON, Antoine. O juiz e a democracia: o guardião das promessas. Trad. Maria Luiza de Carvalho. 2. ed. Rio de Janeiro: Revan, 2001.

GARCÍA-PELAYO, Manuel. El estado de partidos. Madrid: Alianza, 1986.

GARNHAM, Nicholas. The media and public sphere. In: CALHOUN, Craig (Ed.). Habermas and the public sphere. Cambridge/Massachusets: MIT Press, 1992.

GARY, J. O liberalismo. Trad. M. H. Costa Dias. Lisboa: Estampa, 1988.

GASPARI, Elio. A ditadura escancarada. São Paulo: Companhia das Letras, 2002. 
GIDDENS, Anthony. The third way: the renewal of social democracy. Cambridge: Polity Press, 1998.

As consequências da modernidade. Trad. Raul Ficker. São Paulo: Editora da UNESP, 1991.

GOLDSWORTHY, Jeffrey. Parliamentary Sovereignity - Contemporary debates. Cambrigde: Cambridge University Press, 2010.

GOHN, Maria da Glória. Teoria dos movimentos sociais. São Paulo: Loyola, 2004.

GOMES, Neusa Demartini. Formas persuasivas de comunicação política. 2. ed. Porto Alegre: EDIPUCRS, 2001.

GOMES, Wilson; MAIA, Rousiley C. M.; MARQUES, F.P. J.A. Internet $e$ participação política no Brasil. Porto Alegre: Sulina, 2011.

; FERNANDES, Breno; REIS, Lucas; SILVA, Tarcísio. Politics 2.0: a campanha online de Barack Obama em 2008. Revista Sociológica Política, Curitiba, v. 17, out. 2009.

GRAMSCI, Antonio. Cadernos do cárcere. Vol. 3. Rio de Janeiro: Civilização Brasileira, 2011.

GREEN, Philip. Retrieving democracy in search of civic equality. New Jersey: Rowman \& Allanheld, 1985.

GRINOVER, Ada Pelegrini. Da class action for damages à ação de classe brasileira: os requisitos de admissibilidade. Revista de Processo, São Paulo, v. 26, p. 11, jan./mar. 2001.

HABERMAS, Jürgen. A inclusão do outro - estudos de teoria política. Trad. George Sperber, Paulo Astor Soethe e Milton Camargo Mota. 3. ed. São Paulo: Loyola, 2007. . Mudança estrutural da esfera pública. São Paulo: Tempo Brasileiro, 1984. Teoria de la acción comunicativa. Madrid: Taurus, 1987.

HAMILTON, A.; MADISON, J.; JAY, J. Os Artigos Federalistas. Rio de Janeiro: Nova Fronteira, 1993.

HAURIOU, Maurice. Principes de droit publique. 2. ed. Paris: Recueil Sirey, 1916.

HEGEL, G.W.F. Filosofia do direito. Trad. Orlando Vitorino. 2. ed. São Paulo: Martins Fontes, 2003.

HOBBES, Thomas. O Leviatã, ou matéria, forma ou poder de um estado eclesiástico e civil. São Paulo: Martins Fontes, 2008. 
HOHLFELDT, Antonio; MARTINO, Luiz; FRANÇA, Vera Veiga. Teorias da comunicação: conceitos, escolas e tendências. Petrópolis, RJ: Vozes, 2001.

HOLBERT, R. GLEASON, L. A new era of minimal effects? A response to Bennett and Iyengar. Journal of Communication, Milwaukee, 60, p.15-34, 2010.

HOLLANDA, Sérgio Buarque de. Raízes do Brasil. São Paulo: Companhia das Letras, 1995.

HOLLANDER, Barry. Explaining the "bandwagon" "and "underdog” effects: a study of personal relevance and uncertainty orientation as factors in public opinion poll influence.” 1991. Tese (Doutorado em Filosofia) - Universidade da Flórida, Gainesville, 1991. Disponível em:

$<$ https://archive.org/stream/explainingbandwa00holl\#page/5/mode/2up>. Acesso em: 28 nov. 2013.

HUNTINGTON, Samuel. O choque de civilizações e a recomposição da ordem mundial. Rio de Janeiro: Objetiva, 1997.

The third wave: democratization in the late twentieth century. Oklahoma: University of Oklahoma Press, 1991.

JEHÁ, Pedro Rubez. Os partidos políticos em cenário eleitoral. In: CAGGIANO, Monica Herman S. (Coord.). Direito eleitoral em debate: estudos em homenagem a Cláudio Lembo. São Paulo: Saraiva, 2013.

JENKINS, Henry. Cultura da convergência. São Paulo: Aleph, 2006.

KANT, I. A paz perpétua e outros opúsculos. Trad. A. Mourão. Lisboa: Editora 70, 1985.

Que significa orientar-se no pensamento? Trad. Artur Morão. Disponível em: $<$ http://www.lusosofia.net/textos/kant_que_significa_orientar_se_no_pensamento_178 6_.pdf $>$. Acessado em: 22 out. 2013.

KATZ, Richard; MAIR, Peter. The membership of political parties in Western democracies. European Journal of Political Research, Colchester, 22, p. 329-345, 1992.

KELSEN, Hans. A democracia. Trad. Ivone C. Benedetti. São Paulo: Martins Fontes, 1993.

Teoria geral do direito e do estado. Trad. Luís Carlos Borges. São Paulo:

Martins Fontes, 2000.

KINZO, Maria D’Alva Gil. Representação política e sistema eleitoral no Brasil. São Paulo: Símbolo, 1980.

KIRCHHEIMER, Otto. The catch-all party. In: MAIR, Peter (Org.). The western European party system. Oxford: Oxford University Press, 1990. 
KUNSCH, Margarida M. K. Organizações, cidadania, comunicação e os limites entre as estratégias e a ética. In: MOREIRA, Sônia Virgínia. Mídia, ética e sociedade. Belo Horizonte: PUC Minas/INTERCOM, 2004.

KUNTZ, Ronald A. Marketing político: manual de campanha eleitoral. 11. ed. São Paulo: Global, 2006.

LAVALLE, G.A. Crítica ao modelo da nova sociedade civil. Lua Nova, São Paulo, n. 47, p. 353-364, 1999.

LAZARSFELD, Paul; KATZ, E. Personal influence: the part played by people in the flow of mass communication. New York: Free Press, 1955.

LEAL, Victor Nunes. Coronelismo, enxada e voto: município e o regime representativo no Brasil. 7. ed. São Paulo: Companhia das Letras, 2012.

LEMBO, Claudio. Cronologia básica do Direito Eleitoral Brasileiro. In: LEMBO, Cláudio; CAGGIANO, Monica Herman S. (Coord.). O voto nas Américas. Barueri, SP: Minha Editora; São Paulo: Cepes, 2008, p. 73-106.

Participação política e assistência simples no direito eleitoral. Rio de Janeiro: Forense Universitária, 1991.

LEMINSKY, Paulo. Toda poesia. São Paulo: Companhia das Letras, 2013.

LEMOS, Ronaldo. Não saber programar é o analfabetismo do futuro. Folha de S. Paulo, São Paulo, 2013. Disponível em: < http://www1.folha.uol.com.br/colunas/ronaldolemos/2013/11/1365651-nao-saberprogramar-e-o-analfabetismo-do-futuro.shtml>. Acesso em: 04 nov. 2013

. Reação ao WikiLeaks põe Internet em risco. Folha de S. Paulo, São Paulo, 2010. Disponível em: <http://www1.folha.uol.com.br/fsp/folhatee/fm2012201006.htm> Acesso em: 20 dez. 2010.

LEONARDI, Mareei. Responsabilidade civil dos provedores de serviços de Internet. São Paulo: Juarez de Oliveira, 2005.

LÉVY, Pierre. A inteligência coletiva: por uma antropologia do ciberespaço. Trad. Luiz Paulo Rouanet. 5. ed. São Paulo: Loyola, 2007.

LIJPHART, Arend. Modelos de democracia. Trad. Roberto Franco. 2. ed. Rio de Janeiro: Civilização Brasileira, 2008.

LIPPMAN, Walter. Public opinion. New York: The MacMillam Company, 1960.

LOCKE, John. Segundo tratado sobre o governo civil. Trad. Magda Lopes e Marisa L. Costa. São Paulo: Vozes, 2005. 
LORENCINI, Bruno C. A responsabilidade do poder político no Estado constitucional sob o paradigma da "democratic responsiveness". 2013. Tese (Doutorado em Direito) - Universidade de São Paulo, São Paulo, 2013.

LOWELL, Abbott Lawrence. Public opinion and popular government. New York: Longmans, Green \& Co, 1913.

LOWENSTEIN, Karl. Teoría de la Constitución. Trad. Alfredo G. Anabitarte. 2. ed. Barcelona: Ariel, 1976.

LULIN, Elisabeth. Voter par internet: un futur proche. Commentaire, Paris, n. 91, p. 530, Automne 2000.

MACHADO, Marcelo Passamini. A Justiça Eleitoral. In: CAGGIANO, Monica Herman S. (Coord.). Direito eleitoral em debate: estudos em homenagem a Cláudio Lembo. São Paulo: Saraiva, 2013.

MACIEL, Guillermo.Del videopoder a la ciberpolitic@. Montevideo: Editorial Técnica, 2009.

MADRUGA, Sidney Pessoa. Propaganda eleitoral. Espécies. Propaganda antecipada. Propaganda na Internet. In: RAMOS, André de Carvalho (Coord.). Temas do direito eleitoral no século XXI. Brasília: Escola Superior do Ministério Público da União, 2012, p. 392-393.

MAINWARING, Scott. Políticos, partidos e sistemas eleitorais: o Brasil numa perspectiva comparada. Trad. Otacílio F. Nunes Jr. Novos Estudos Cebrap, São Paulo, n. 29, p. 34-58, 1991.

MANIN, Bernard. As metamorfoses do governo representativo. Revista Brasileira de Ciências Sociais, São Paulo, n. 29, ano 10, p. 5-34, out. de 1995.

. Los principios del gobierno representativo. Trad. Fernando Vallespín. Madrid: Alianza, 1998.

MANIN, B.; PRZEWORSKI, A.; STOKES, S. Democracy, accountability and representation. Nova York: Cambridge University Press, 1999.

MARCHETTI, Vitor. O “Supremo Tribunal Eleitoral”: a relação entre STF e TSE na governança eleitoral brasileira. Revista Brasileira de Estudos Constitucionais - RBEC. Belo Horizonte, ano 5, n. 20, p. 161 - 180, out./dez. 2011.

MARRONE, Gianfranco. Da opinião pública ao corpo político. Galáxia: revista transdisciplinar de comunicação, semiótica, cultura. São Paulo: EDUC, n. 2, p. 57-98, 2001.

MARSHALL, Thomas H. Cidadania, classe social e status. Rio de Janeiro: Zahar, 1967. 
MARTELETO, Regina M. Análise de redes sociais: aplicação nos estudos de transferência da informação. Ciência da Informação, Brasília, v. 30, n. 1, p. 71-81, jan/abr. 2001.

MARX, Karl; ENGELS, Friedrich. Manifesto do partido comunista. São Paulo: Cortez, 1998.

MATTEUCCI, Nicola. Verbete: Soberania. In: BOBBIO, Norberto; MATTEUCI, Nicola; PASQUINO, Gianfranco. Dicionário de Política. Brasília: UnB, 1986.

MAUSER, Gary. Political marketing: an approach to campaign strategy. New York: Praeger, 1983.

MEDINA, Ademir Ismerim. Comentários à lei eleitoral. 3. ed. São Paulo: Quartier Latin, 2004.

MELO, José Marques de. A esfinge midiática. São Paulo: Paulus, 2004.

MELUCCI, Alberto. A invenção do presente: movimentos sociais nas sociedades complexas. Petrópolis, RJ: Vozes, 2001.

49-66.

Um objeto para os movimentos sociais. Lua Nova, São Paulo, n. 17, p. 57, p.

MENDES, Gilmar Ferreira; COELHO, Inocêncio Mártires; BRANCO, Paulo Gustavo Gonet. Curso de direito constitucional. 4. ed. São Paulo: Saraiva, 2009.

MEYNAUD, Jean. Les groupes de pression. Paris: Presses Universitaires de France, 1962.

MICHELS, Robert. Sociologia dos partidos políticos. Trad. Arthur Chaudon. Brasília: Universidade de Brasília, 1982 (Coleção Pensamento Político, nº 53).

MIGUEL, Luís Felipe. Mito e discurso político: uma análise a partir da campanha eleitoral brasileira de 1994. Campinas, SP: Editora da Unicamp: Imprensa Oficial, 2000.

Os meios de comunicação e a prática política. Lua Nova, São Paulo, n. 55-56, p. 155-184, 2002.

Representação política em 3-D: elementos para uma teoria ampliada de representação política. São Paulo, Revista Brasileira de Ciências Sociais, vol. 18, n. 51, 2003. Disponível em: <http://www.scielo.br/pdf/rbcsoc/v18n51/15989>. Acesso em: 15 fev. 2011.

MILL, John Stuart. Considerações sobre o governo representativo. Brasília: Editora da Universidade de Brasília, 1981.

MIRANDA, Jorge. Manual de direito constitucional. Tomo IV, 2. ed. Coimbra: Coimbra Editora, 1998. 
Os direitos fundamentais - sua dimensão individual e social. Revista dos

Tribunais. São Paulo, Ano 1, p. 202, out./dez. de 1992.

MONTESQUIEU, Charles Louis de Secondat, baron de la Brède et de. Do espírito das leis. Trad. Gabriela de Andrada Dias Barbosa. Rio de Janeiro: Ediouro, 1985.

MORAES, Alexandre de. Direito Constitucional. São Paulo: Atlas, 2001.

MOSCA, Gaetano; BOUTHOUL, Gaston. História das doutrinas políticas desde a Antiguidade. Trad. Marco Aurélio de Moura Matos. 6. ed. Rio de Janeiro: Zahar, 1983.

MOSSBERGER, K., TOLBERT, C.; McNEAL, R. Digital citizenship: the Internet, society, and participation. Cambridge: MIT Press, 2007.

MÜLLER, Friedrich. Quem é o povo: a questão fundamental da democracia. Trad. Peter Naumann. 4. ed. São Paulo: Revisa dos Tribunais, 2009.

NICOLAU, Jairo Marconi. História do voto no Brasil. 2. ed. Rio de Janeiro: Jorge Zahar, 2004.

Sistemas eleitorais. 5. ed. Rio de Janeiro: Editora FGV, 2004.

NOELLE-NEUMANN, Elisabeth. La espiral del silencio - Opinión pública: nuestra piel social. Barcelona: Paidós, 1995.

NOGUEIRA, M.A. Sociedade civil, entre o político-estatal e o universo gerencial. Revista Brasileira de Ciências Sociais, São Paulo, v. 18, n. 52, p. 57, 2003.

NORRIS, P. The impact of the Internet on political activism: evidence from Europe, International. Journal of Electronic Government Research, Harvard, v. 1, n. 1, p. 2039, 2005.

O’DONNELL, Guillermo. Accountability horizontal e novas poliarquias. Lua Nova, São Paulo, nº 44, p. 27-54, 1998.

OSTROGORSKI, Moisei. La démocratie et les partis politiques. Paris: Calmann-Lévy, 1912.

PARAJÓ, Eduardo Fumes. Marco civil: por uma internet livre. Folha de S. Paulo, São Paulo, 2013. Disponível em: < http://www1.folha.uol.com.br/fsp/opiniao/87417-marcocivil-por-uma-internet-livre.shtml. Acesso em: 7 jan. 2013.

PETIT, Philip. Republican theory and political trust. In: BRAITHWAITE, Valerie; LEVI, Margaret (Ed.). Trust and governance. New York: Russell Sage Foundation, 1998, p. 295-314.

PEREA, Eva Anduzia. ¿Indivíduos o sistema? Las razones de la abstención en Europa Occidental. Madrid: Centro de Investigaciones Sociológicas/Siglo XXI, 1999. 
PÉREZ-LUÑO, PÉREZ LUÑO, Antonio Enrique. ¿CibercidadanÍ@ o ciudadanI@.com? Barcelona: Gedisa, 2004.

PINTO FERREIRA. Princípios gerais de direito constitucional moderno. $1^{\circ}$ vol. São Paulo: Revista dos Tribunais, 1971.

PITKIN, Hannah Fenichel. The concept of representation. Berkeley: University of California Press, 1967.

PLOTKE, D. What's so new about new social movements? Socialist review, Londres, v. 20, n. 1, p. 46-87, 1992.

POLETTI, Ronaldo. O partido político na Constituição. Revista de Informação Legislativa, Brasília, v. 24, n. 93, p. 106, jan./mar. 1987.

PORTO, Walter Costa. O voto no Brasil. Rio de Janeiro: Topbooks, 2002.

PRADO, Adélia. Sala de Espera. In: Miserere. Rio de Janeiro: Record, 2013.

PRIOR, M. Post-broadcast democracy: how media choice increases inequality in political involvement and polarizes elections. Cambridge: Cambridge University Press, 2007.

PRZEWORSKI, Adam. Minimalist conception of democracy: a defense. In: SHAPIRO, Ian; CORDÓN-HACKER, Cassiano (Ed.). Democracy's value. Cambridge: Cambridge University Press, 1999.

Democracia e mercado. Rio de Janeiro: Relume-Dumará, 1994.

PUTNAM, Robert. Bowling alone. New York: Simon and Schuster, 2000.

RAMOS, Wolney. Propaganda política. São Paulo: Companhia Mundial de Publicação, 2007.

RAWLS, John. Justiça como equidade: uma concepção política, não metafísica. Lua Nova, São Paulo, vol. 25, p. 25-59, 1992.

Uma teoria da justiça. São Paulo: Martins Fontes, 2000.

REALE, Miguel. O sistema de representação proporcional e o regime presidencial brasileiro. Revista Brasileira de Estudos Políticos, Belo Horizonte, n. 7, p. 24, nov. 1959.

RECUERO, Raquel. Redes sociais na Internet. Porto Alegre: Sulina, 2009 (Coleção Cibercultura).

RHEINGOLD, Howard. A comunidade virtual. Lisboa: Gradiva, 1996.

RIBEIRO, Fávila. Direito eleitoral. 5. ed. Rio de Janeiro: Forense, 1988. 
RIBEIRO, Renato Ventura. Lei eleitoral comentada. São Paulo: Quartier Latin, 2006.

ROCHA, Carmen Lúcia Antunes. O processo eleitoral como instrumento para a democracia. Resenha Eleitoral - Nova Série, Florianópolis, v. 5, n. 1, jan./jun. 1998.

ROSAVALLON, Pierre. La legitimité democratique: impartialité, reflexivité, proximité. Paris: Éditions du Seuil, 2008.

ROSENZWEIG, Franz. Hegel e o Estado. Trad. Ricardo Timm de Souza. São Paulo: Perspectiva, 2008.

ROUSSEAU, Jean-Jacques. Discurso sobre a origem e os fundamentos da desigualdade entre os homens. São Paulo: Nova Cultural, 1999.

. O contrato social. Trad. Antonio de Pádua Danesi. 4. ed. São Paulo: Martins Fontes, 2006.

RUBIM, Antonio A. C. Comunicação e política. São Paulo: Hacker, 2000.

Eleições e (Idade) Mídia. In: BARROS FILHO, Clóvis de. Comunicação na pólis: ensaios sobre mídia e política. Petrópolis, RJ: Vozes, 2002.

SAMPAIO, Nelson de Souza. Eleições e sistemas eleitorais. Revista de Jurisprudência, Rio de Janeiro, p. 66, $1^{\circ}$ trimestre, 1981.

SÁNCHEZ AGESTA, Luis. Democracia y processos electorales. Costa Rica: CAPEL, 1986.

Princípios de teoria política. 6. ed. Madrid: Nacional, 1976.

SÁNCHEZ MUÑOZ, Oscar. La igualdad de oportunidades en las competencias electorales. Madrid: Centro de Estudios Politicos y Constitucionales, 2007.

SANSON, Alexandre. Dos grupos de pressão na democracia representativa: os limites jurídicos. 2013. Tese (Doutorado em Direito) - Universidade de São Paulo, São Paulo, 2013.

SANTOS, Milton. O espaço do cidadão. 7. ed. São Paulo: EDUSP, 2007.

SARASATE, Paulo. A Constituição do Brasil ao alcance de todos. Rio de Janeiro: Freitas Bastos, 1967.

SARTORI, Giovanni. Homo videns: televisão e pós-pensamento. Trad. Antonio Angonese. Bauru: EDUSC, 2001.

Comparative constitutional engineering. 2. ed. New York: New York University Press, 1997.

A teoria da democracia revisitada. Vol. I - O debate contemporâneo. Trad. Dinah Abreu de Azevedo. São Paulo: Ática, 1994. 
1982.

. Partidos e sistemas partidários. Brasília: Editora Universidade de Brasília,

SCHERER-WARREN, Ilse. Movimentos sociais e educação na era da informação.

Revista de Educação Pública, Cuiabá, v. 19, p. 139-145, 2002.

SCHMITT, Carl. O conceito do político/Teoria do partisan. Trad. Geraldo de Carvalho. Belo Horizonte: Del Rey, 2008.

. Teoría de la Constitución. Trad. Francisco Ayala. Madrid: Alianza, 2006.

SCHUMPETER, Joseph. Capitalismo, socialismo e democracia. Rio de Janeiro: Zahar, 1967.

SCHWARTZENBERG, Roger-Gérard. O Estado espetáculo: ensaio contra o star system em política. São Paulo: Círculo do Livro, 1977.

SIEYÈS, Emmanuel J. Que é o Terceiro Estado? Trad. Norma Azeredo. São Paulo: Líber Juris, 1988.

SILVA, Luís Virgílio Afonso da. Sistemas eleitorais. tipos, efeitos jurídico-políticos e aplicação ao caso brasileiro. São Paulo: Malheiros, 1999.

SILVEIRA, Sérgio Amadeu de. Combates na fronteira eletrônica: a Internet nas eleições de 2006. In: LIMA, Venício Artur de. A mídia nas eleições 2006. São Paulo: Fundação Perseu Abramo, 2007.

SMITH, Aaron; RAINIE, Lee. The Internet and the 2008 election. Disponível em: $<$ http://www.pewinternet.org/ /media/Files/Reports/2008/PIP_2008_election.pdf.pdf>. Acesso em: 4 out. 2012.

SOUZA, Randolph Aparecido de. A estética do mashups. 2009. Dissertação (Mestrado em Tecnologia da Inteligência e Design Digital) - Pontifícia Universidade Católica de São Paulo, São Paulo, 2009.

SUSTEIN, Cass. Republic.com 2.0. Princeton: Princeton University Press, 2007.

TOCQUEVILLE, Alexis de. Lembranças de 1848: as jornadas revolucionárias em Paris. Trad. Modesto Florenzano. São Paulo: Companhia das Letras, 2011.

A democracia na América: leis e costumes de certas leis e certos costumes políticos que foram sugeridos aos americanos por seu estado social democrático. Livro I. Trad. Eduardo Brandão. 2. ed. São Paulo: Martins Fontes, 2005.

TOURAINE, Alan. O retorno do actor: ensaio sobre sociologia. São Paulo: Instituto Piaget, 2006.

TRECHSEL, Alexander. Report for the Council of Europe: Internet Voting in the March 2007. Parliamentary Elections in Estonia. Council of Europe. Disponível em: $<$ http://votingtechnology 
project.org/drupal/files/report/internet_voting_estonia_2007.pdf>. Acesso em: 23 dez. 2013.

URBINATI, Nadia. Da democracia dos partidos ao plebiscito da audience. Lua Nova, São Paulo, n. 89, p. 85-105, jan./jun. 2013. 228, 2006.

O que torna a representação democrática? Lua Nova, São Paulo, n. 67, p. 191of Chicago, 2006.

VILLA, Marco Antonio. A história das constituições brasileiras. São Paulo: Leya, 2011.

VILLEY, Michel. Filosofia do direito - definições de fins do direito. Os meios do direito. Trad. Márcia Valéria Martinez de Aguiar. São Paulo: Martins Fontes, 2003.

VITA, Álvaro de. Democracia deliberativa ou igualdade de oportunidades políticas? Novos Estudos Cebrap, São Paulo, n. 66, p. 111-128, jul. 2003.

VRABIE, Genoveva. Etudes de droit constitutionnel. Iași: Institutul European, 2003.

WARD, S.; GIBSON, R.; NIXON, P. Parties and the Internet. In: WARD, S.; GIBSON, R.; NIXON, P. (Ed.). Political parties and the Internet: net gain? London and New York: Taylor and Francis Group, 2003.

WILLIAMS, Andrew P.; TEDESCO, John C. The internet election: perspectives on the web in campaign 2004. Oxford: Rowman \& Littlefield Publishers, 2006.

WOLTON, Dominique. Internet et après? Une théorie critique de nouveaux médias.

Paris: Flammarion, 2000. 